
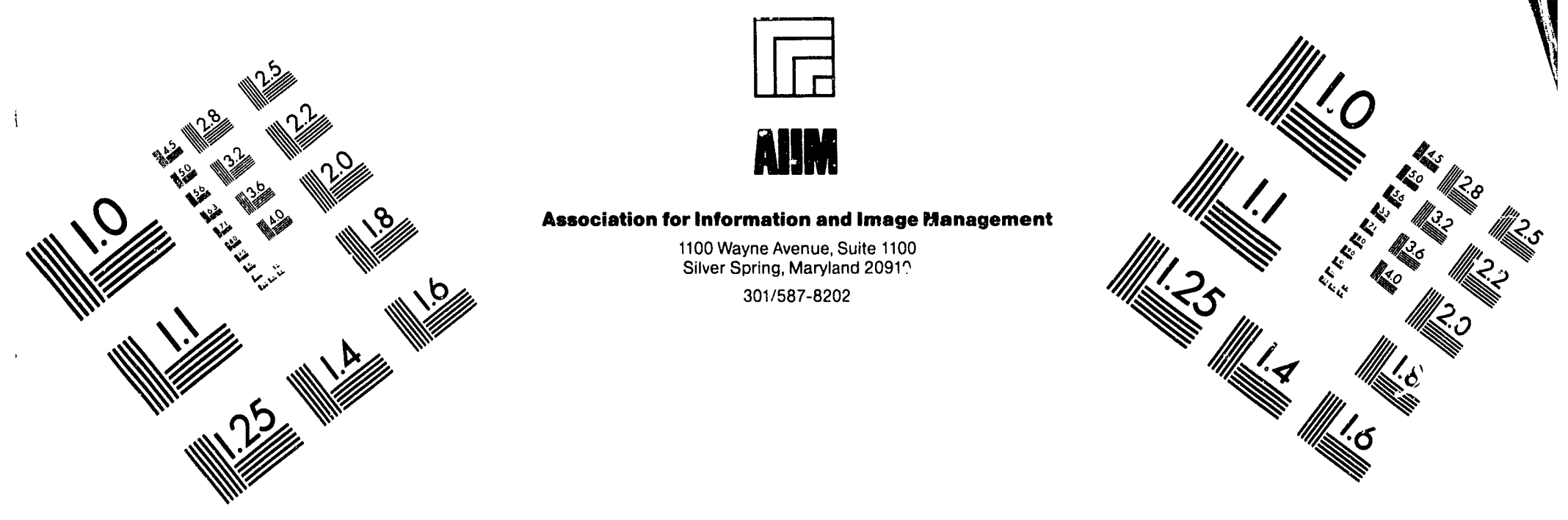

Centimeter

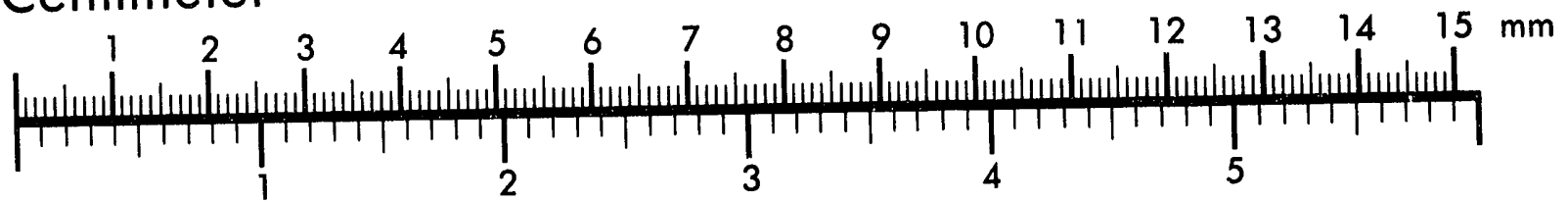
Inches
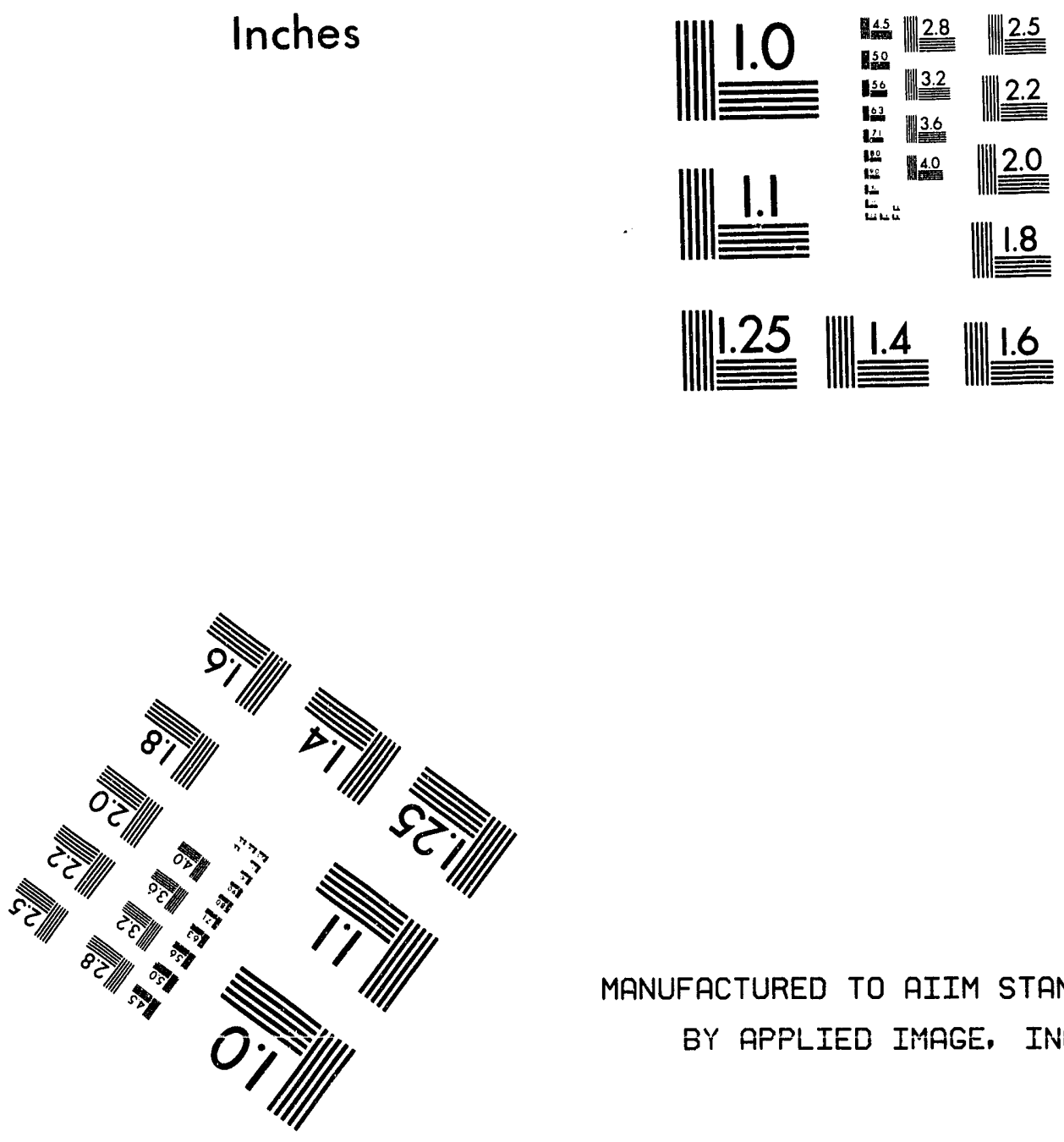

MANUFACTURED TO AIIM STANDARDS

BY APPLIED IMAGE, INC.

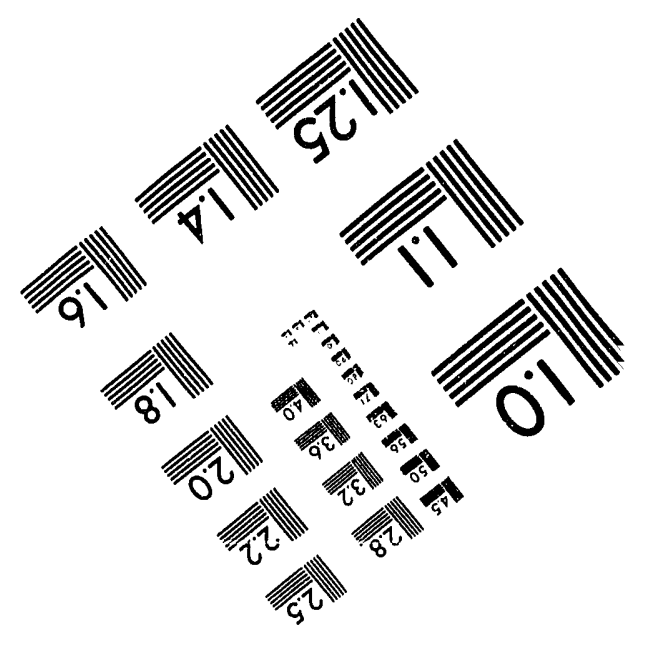



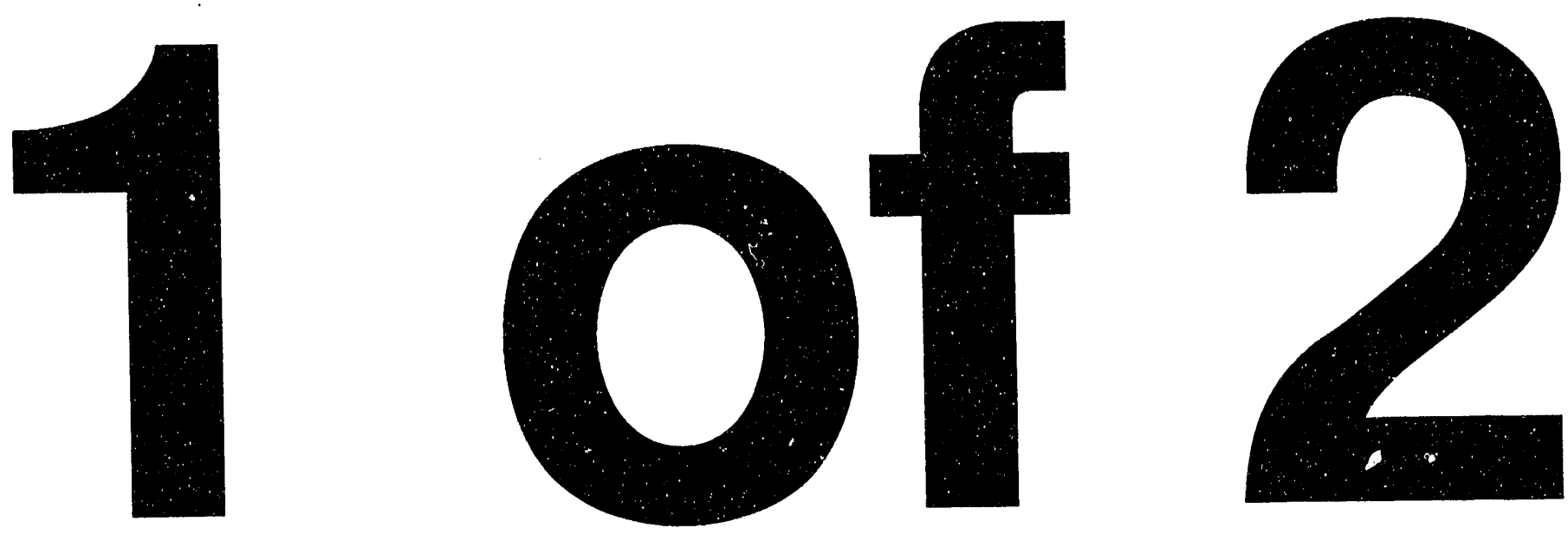


\section{Remedial Investigation/ Feasibility Study Work Plan for the 100-BC-2 Operable Unit, Hanford Site, Richland, Washington}

Date Published

May 1993

\section{DISCLAIMER}

This report was prepared as an account of work sponsored by an agency of the United States Government. Neither the United States Government nor any agency thereof, nor any of their employees, makes any warranty, express or implied, or assumes any legal liability or responsibility for the accuracy, completeness, or usefulness of any information, apparatus, product, or process disclosed, or represents that its use would not infringe privately owned rights. Reference herein to any specific commercial product, process, or service by trade name, trademark, manufacturer, or otherwise does not necessarily constitute or imply its endorsement, recommendation, or favoring by the United States Government or any agency thereof. The views and opinions of authors expressed herein do not necessarily state or reflect those of the United States Government or any agency thereof.

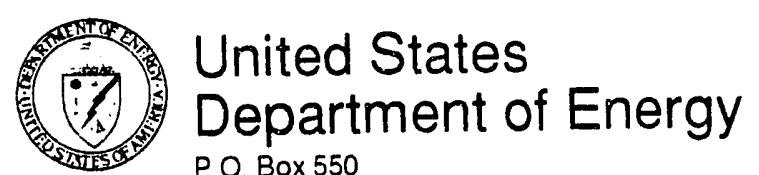

P O Box 550

Richland, Washington 99352 


\section{TRADEMARK DISCLAIMER}

Reference herein to any specific commercial product, process, or service by trade name, trademark, manufacturer, or otherwise, does not necessarily constitute or imply its endorsement, recommendation, or favoring by the United States Government or any agency thereof or its contractors or subcontractors.

This report has been reproduced from the best available copy. Available in paper copy and microfiche.

Available to the U.S. Department of Energy

and its contractors from

Office of Scientific and Technical Information

P.O. Box 62

Oak Ridge, TN 37831

(615) 576.8401

Available to the public from the U.S. Department of Commerce National Technical Information Service

5285 Port Royal Road

Springfield, VA 22161

(703) $487-4650$

Printed in the United States of America

DISCLM-5.CHP (8-91) 


\section{EXECUTIVE SUMMARY}

\section{INTRODUCTION}

This work plan and attached supporting project plans establish the operable unit setting and the objectives, procedures, tasks, and schedule for conducting the Comprehensive Environmental Response, Compensation, and Liability Act of 1980 (CERCLA) remedial investigation/feasibility study (RI/FS) for the 100-BC-2 operable unit in the 100 Area of the Hanford Site. The 100 Area is one of four areas at the Hanford Site that are on the U.S. Environmental Protection Agency's (EPA) National Priorities List under CERCLA.

The 100-BC-2 operable unit is one of two source operable units in the $100-\mathrm{B} / \mathrm{C}$ Area (Figure ES-1). Source operable units are those that contain facilities and unplanned release sites that are potential sources of hazardous substance contamination. The 100-BC-2 source operable unit contains waste sites that were formerly in the $100-\mathrm{BC}-2,100-\mathrm{BC}-3$, and $100-\mathrm{BC}-4$ operable units. Because of their size and geographic location, the waste sites from these two operable units were added to $100-\mathrm{BC}-2$. This allows for a more efficient and effective investigation of the remaining $100-\mathrm{B} / \mathrm{C}$ Reactor area waste sites.

All work conducted under this work plan will conform to the conditions set forth in the Hanford Federal Facility Agreement and Consent Order (Ecology et al. 1990a), and its amendments, signed by the Washington Department of Ecology (Ecology), the EPA, and the U.S. Department of Energy (DOE).

The RI/FS process for the 100-BC-2 operable unit follows the path detailed in Figure ES-2. The work scope described in the work plan is a result of the scoping process involving the Ecology, EPA, and DOE, identified as step two in Figure ES-2.

The approach for this work plan is based on the Hanford Site Past-Practice Strategy (DOE-RL 1991a). This strategy streamlines the past-practice remedial action process with a bias for action through optimizing the use of interim actions. This approach culminates with decisions of final remedies on both an operable unit and 100 Area scale. The strategy focuses on reaching early decisions (interim remedial measures [IRM]) to initiate and complete cleanup projects, maximizing the use of existing data, coupled with focused short time-frame limited field investigations (LFI) where necessary.

\section{OVERVIEW}

The investigative approach to waste sites associated with the 100-BC-2 operable unit are listed in Table ES-1. The waste sites fall into three general categories: high priority liquid waste disposal sites, low priority liquid waste disposal sites, and solid waste burial grounds. Several sites have been identified as candidates for conducting an IRM. Two sites have been identified as warranting additional limited field sampling. The two sites are the $116-\mathrm{C}-2 \mathrm{~A}$ pluto crib, and the $116-\mathrm{C}-2 \mathrm{C}$ sand filter. 
The limited field sampling will consist of one borehole at each site. Sampling will take place where field screening instruments detect contamination. Samples collected will be arialyzed for chemical and radiological constituents. The data quality objective process identified the Ecology, EPA, or DOE and technical lead agencies as the primary data users. The primary data uses are: (1) determination of maximum contaminant concentration to support a qualitative risk assessment; (2) define vertical distribution of contaminants; and (3) determine if and when an IRM action is necessary.

A report will be prepared on completion of the LFI. The report will include the results of source investigations, historical investigations, process knowledge, field screening, and geophysical surveys; identify the nature and vertical extent of contamination at the high priority liquid waste sites; identify the contaminant- and location-specific applicable or relevant and appropriate requirements; and provide a summary of the qualitative risk assessment performed for each of the high priority' sites. The report will include an assessment of whether thresholds are exceeded that warrant action through IRM. The LFI report will also evaluate sites analogous to those in the 100-BC-2 operable unit to aid in the determination of the need for an IRM. The LFI report will support the focused FS, which will address remediation options for the waste sites.

The FS process for the 100 Area will be conducted on both an aggregate area and operable unit basis. This process includes preparation of a 100 Area FS, a focused FS, and a final FS. Figure ES-2 displays how the entire RI/FS process culminates in the implementation of remedial actions for the operable unit. 


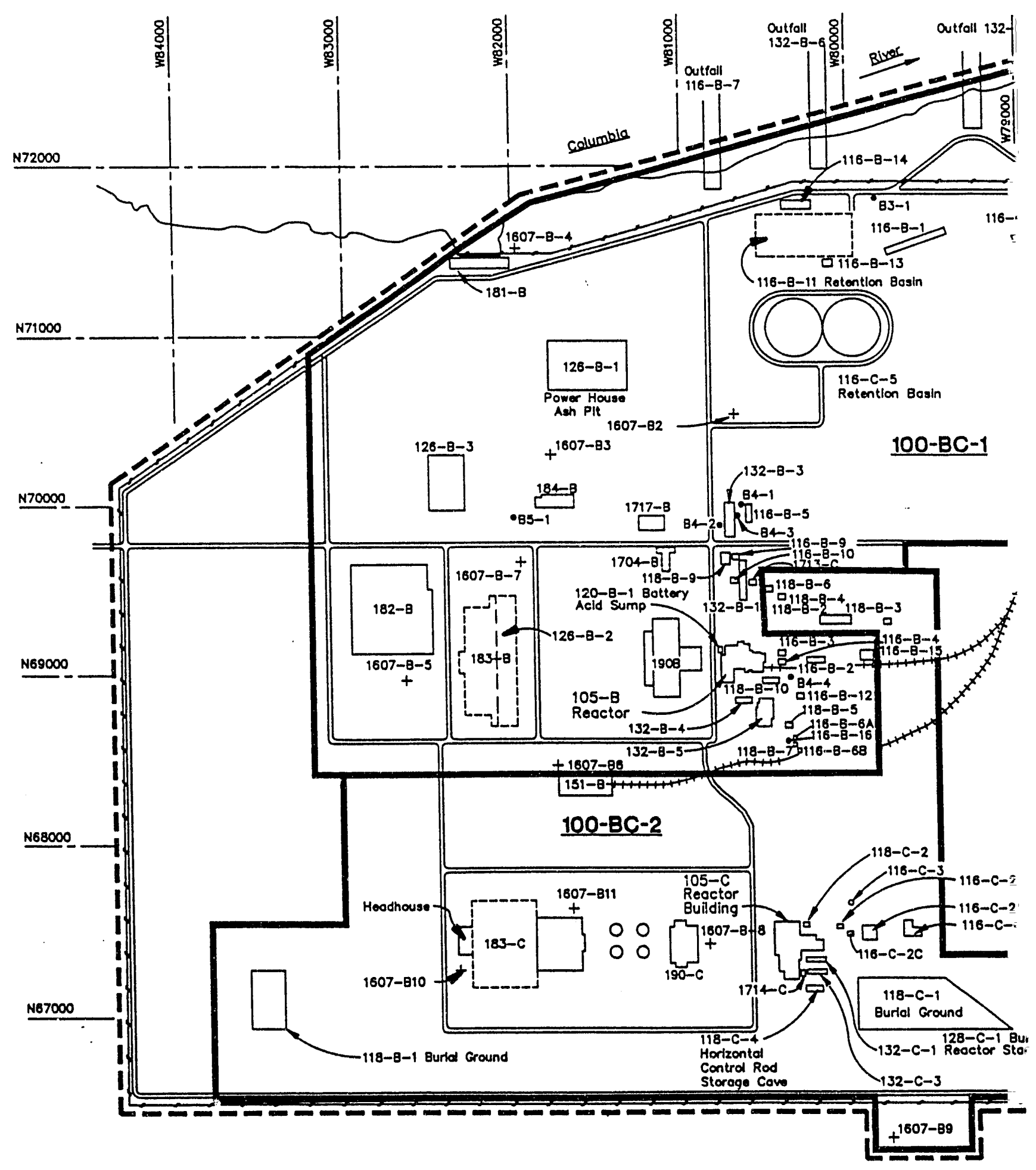

KOK\121192-B 
DOE/RL-91-07, Rev. 0
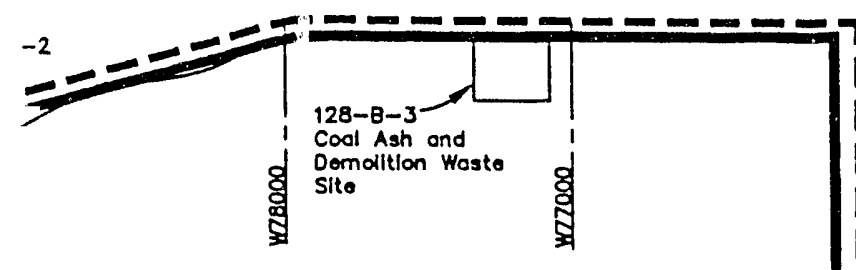

(15-2

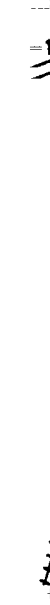

$103-2$

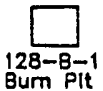

Sand Blast

Dlsposal Sit

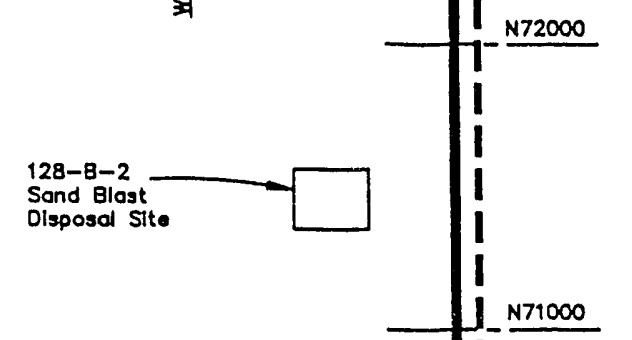

Bum PIt

.
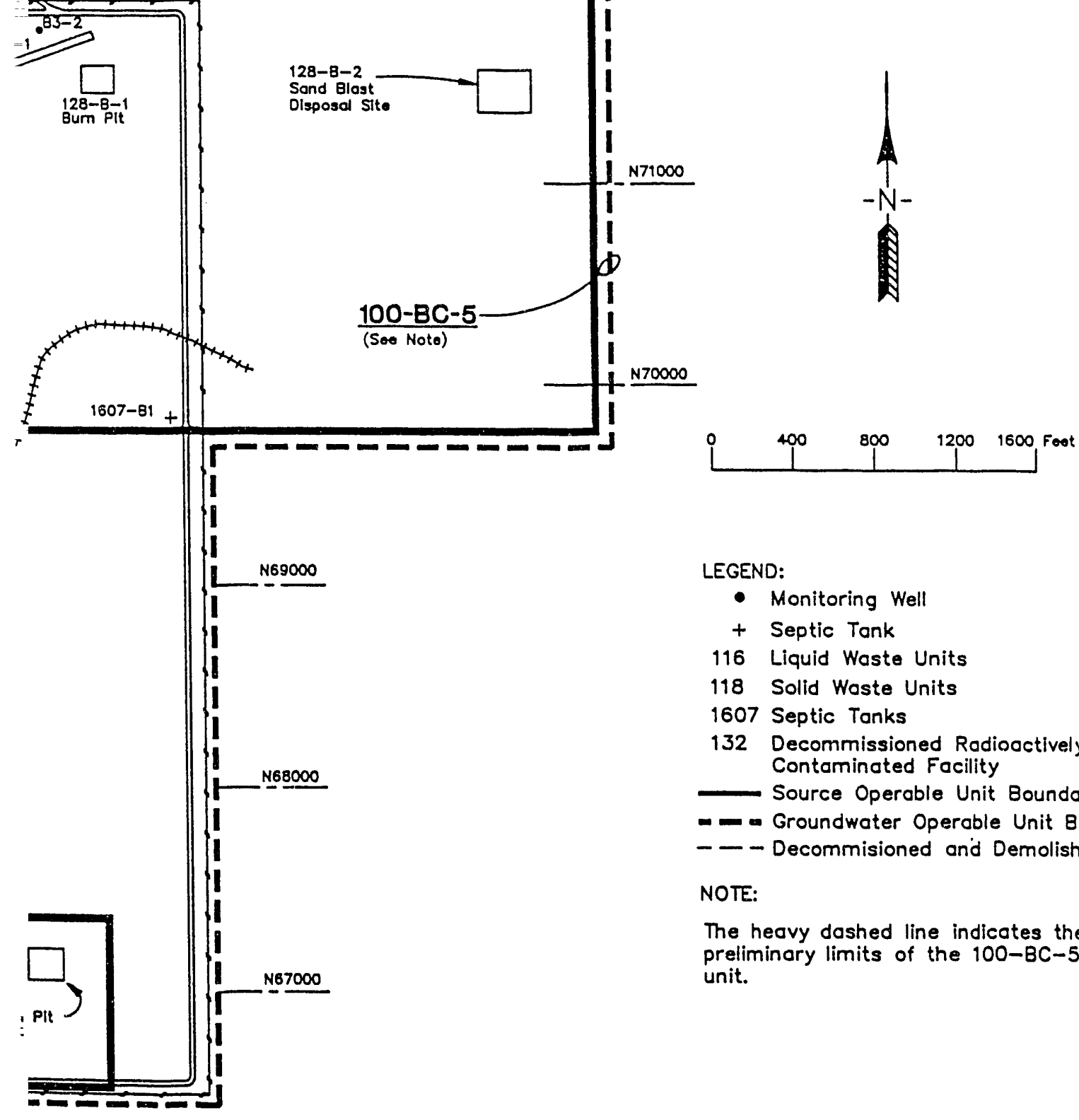

LEGEND:

- Monitoring Well

+ Septic Tank

116 Liquid Waste Units

118 Solid Woste Units

1607 Septic Tanks

132 Decommissioned Radioactively Contaminated Facility

Source Operable Unit Boundary

- - Groundwater Operable Unit Boundory

- - Decommisioned and Demolished Facilities

NOTE:

The heavy dashed line indicates the preliminary limits of the $100-B C-5$ operable unit.

Figure ES-1. 100-B/C Area. 


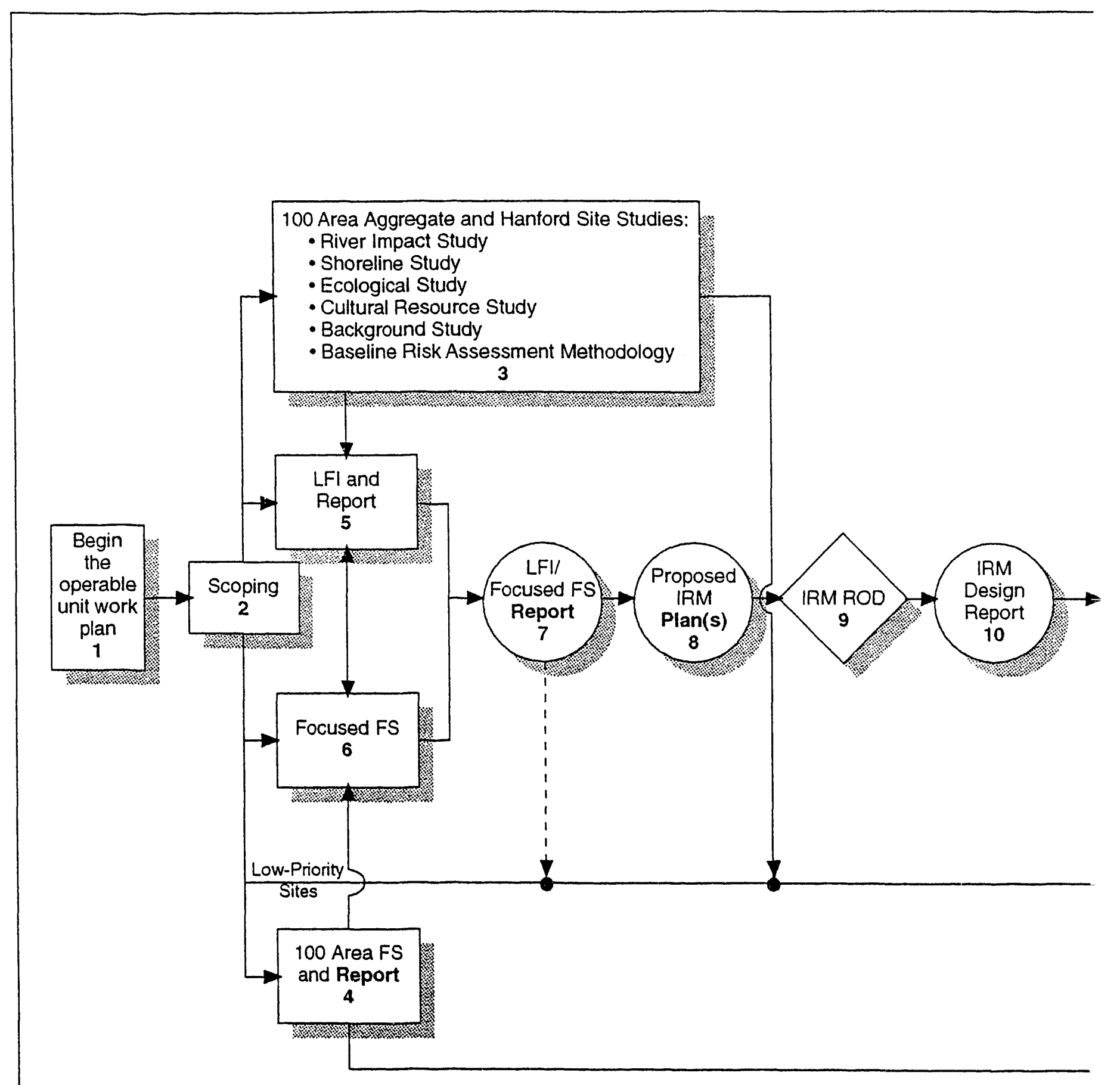



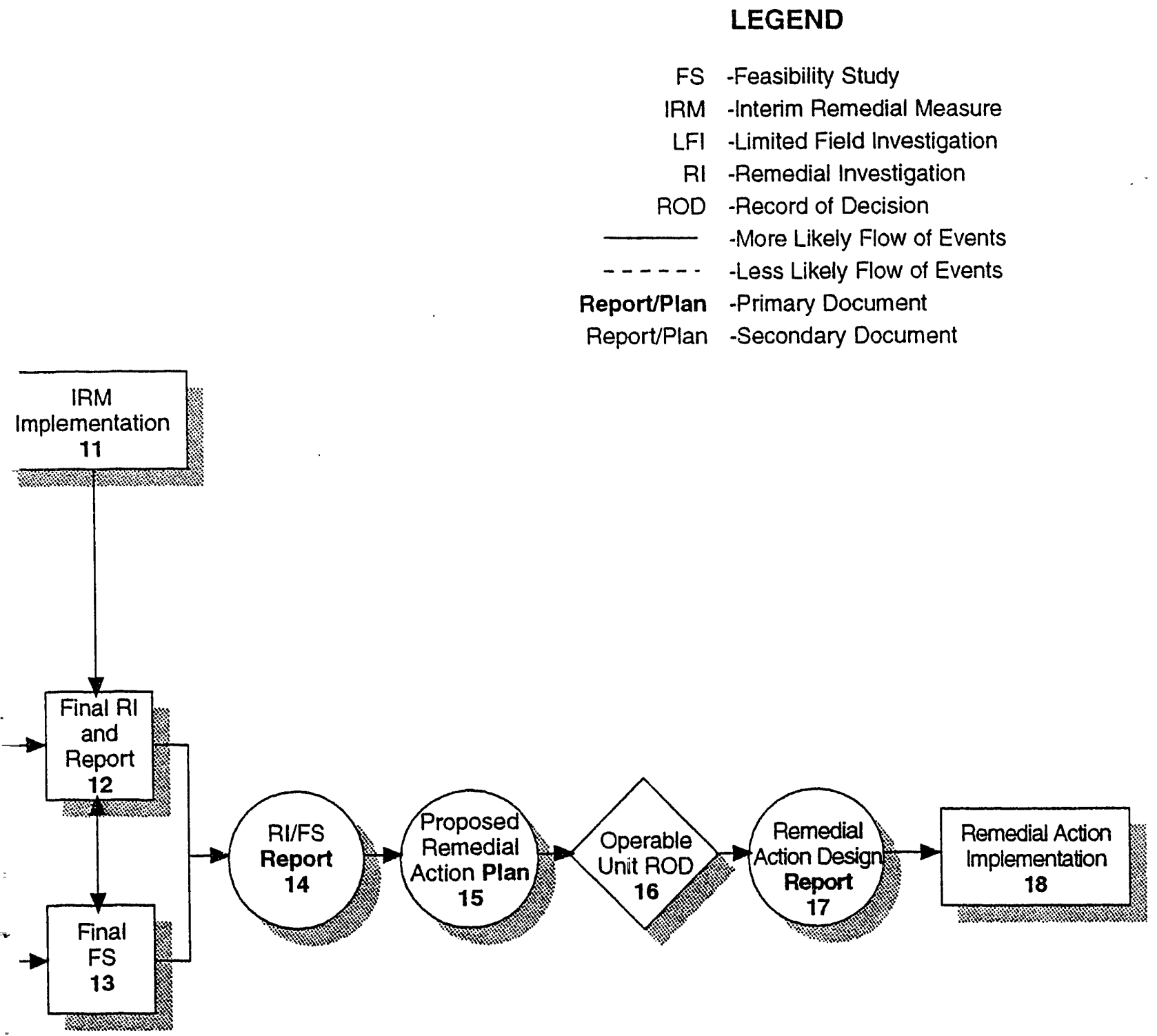

Figure ES-2. RI/FS Process for the 100-BC-2 Operable Unit. 
DOE/RL-91-07, Rev. 0

Table ES-1. Investigative Approach for the 100-BC-2 Operable Unit

(Page 1 of 3)

\begin{tabular}{|c|c|c|c|c|c|c|c|c|}
\hline & 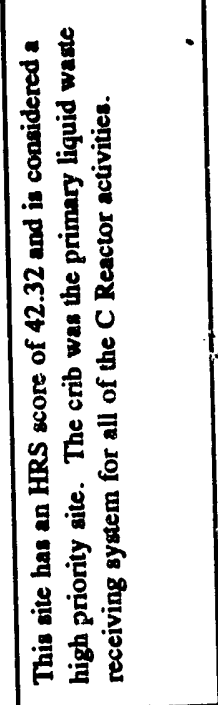 & 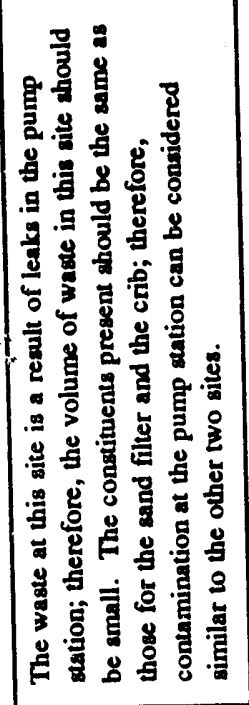 & 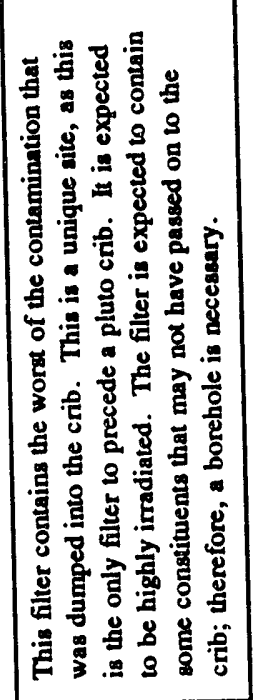 & 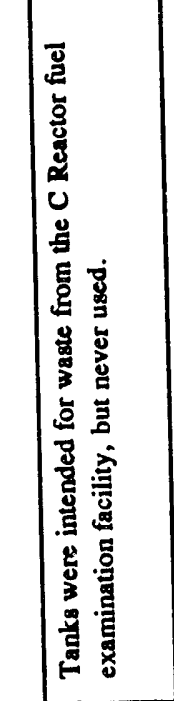 & 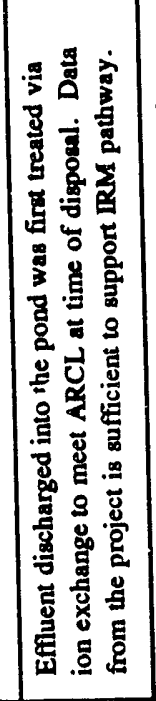 & 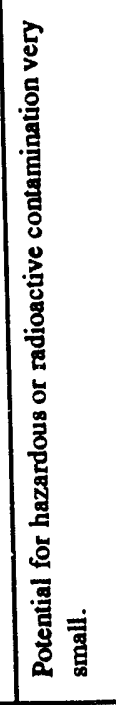 & & \\
\hline 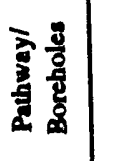 & 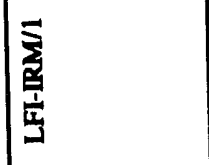 & $\mid \frac{3}{3}$ & $\mid \overrightarrow{\bar{z}}$ & 苟 & 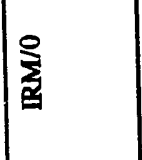 & 量 & & \\
\hline 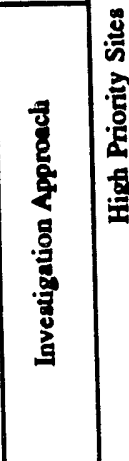 & 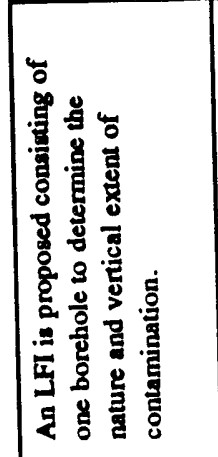 & 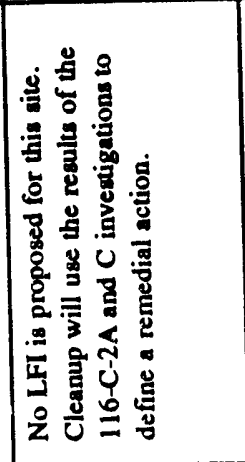 & 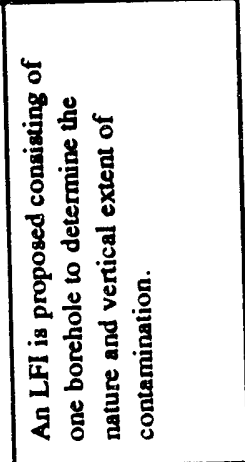 & 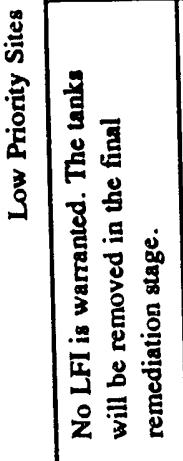 & 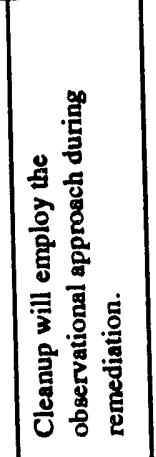 & 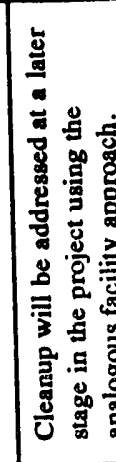 & & \\
\hline 案 & 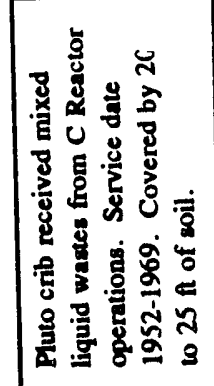 & 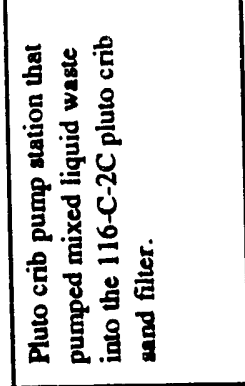 & 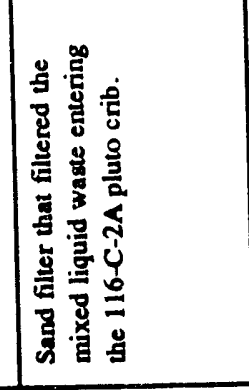 & 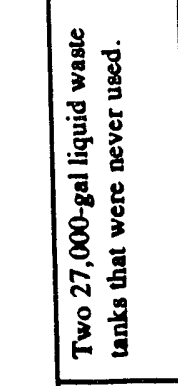 & 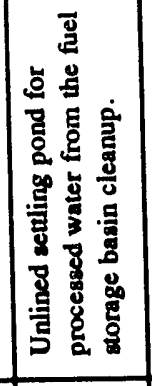 & 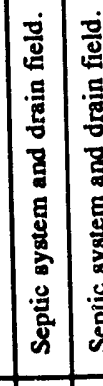 & 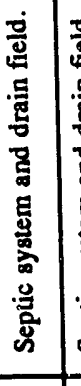 & 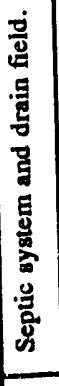 \\
\hline के & 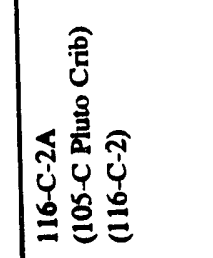 & 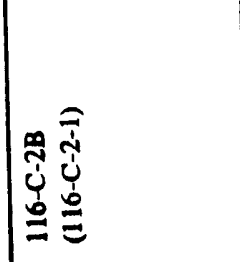 & 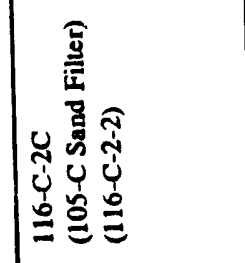 & 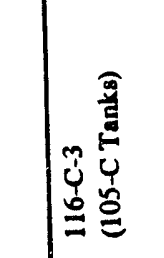 & 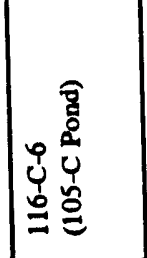 & 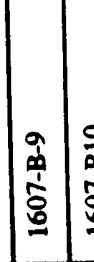 & 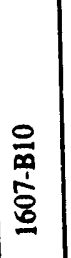 & 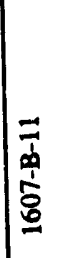 \\
\hline
\end{tabular}

EST-1a 
DOE/RL-91-07, Rev. 0

- Table ES-1. Investigative Approach for the 100-BC-2 Operable Unit

(Page 2 of 3)

\begin{tabular}{|c|c|c|c|c|c|c|c|}
\hline 喜 & \multicolumn{2}{|l|}{ 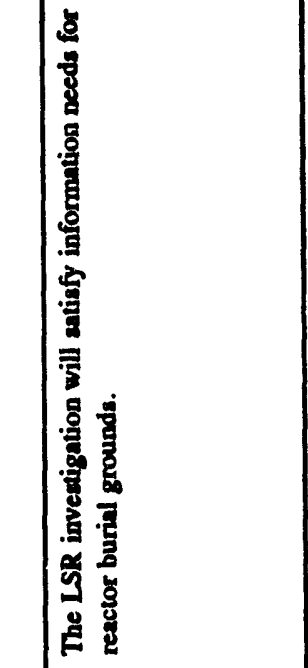 } & \multicolumn{5}{|l|}{ 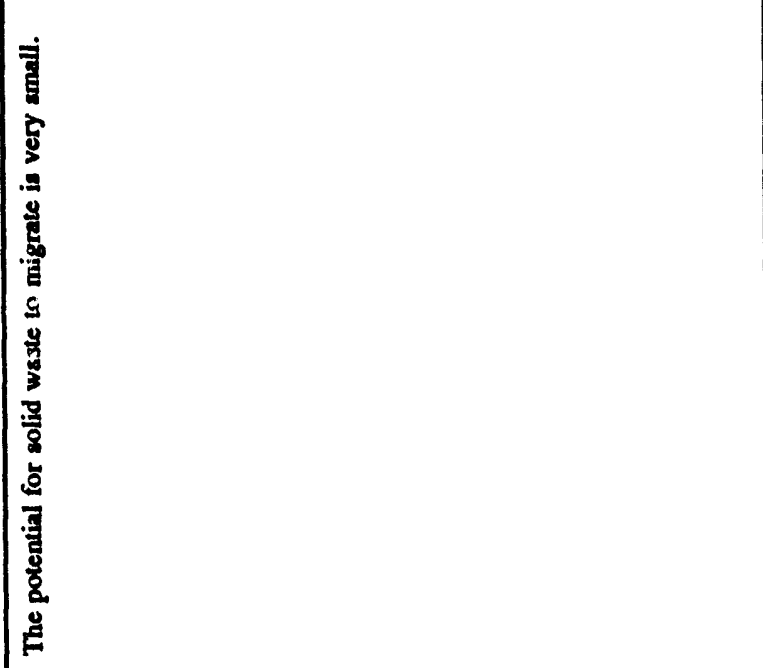 } \\
\hline 言鄫 & \multicolumn{2}{|l|}{ 产 } & \multicolumn{5}{|l|}{ 产 } \\
\hline 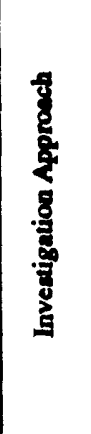 & \multicolumn{2}{|c|}{ 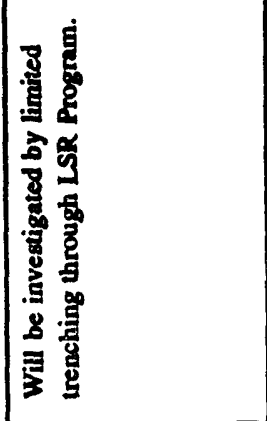 } & \multicolumn{5}{|c|}{ 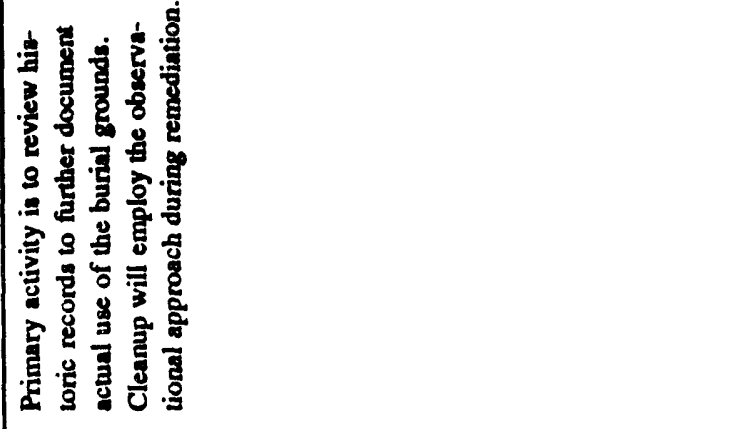 } \\
\hline 晋 & 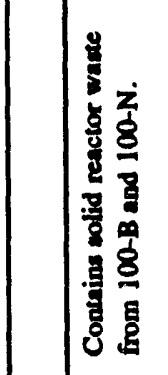 & 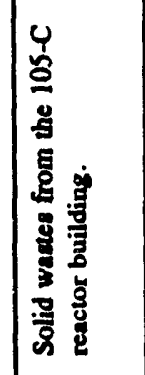 & 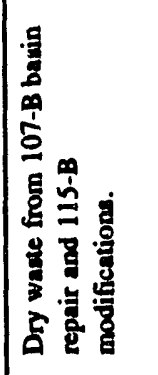 & 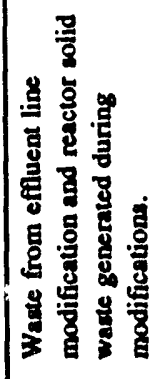 & 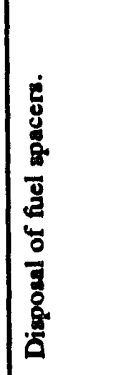 & 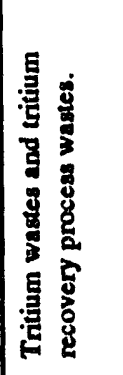 & 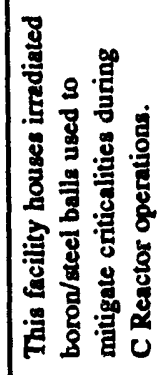 \\
\hline कू & 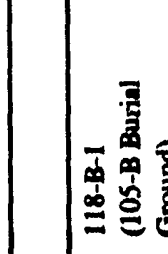 & 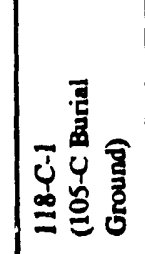 & 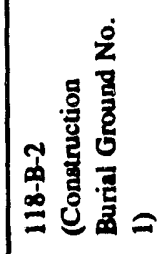 & 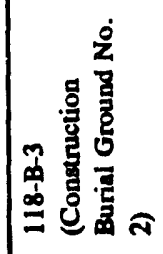 & 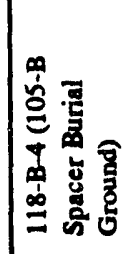 & 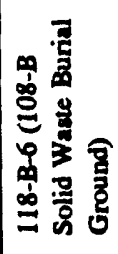 & 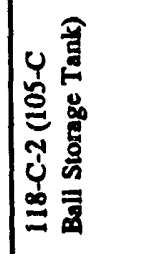 \\
\hline
\end{tabular}


DOE/RL-91-07, Rev. 0

Table ES-1. Investigative Approach for the 100-BC-2 Operable Unit

(Page 3 of 3)

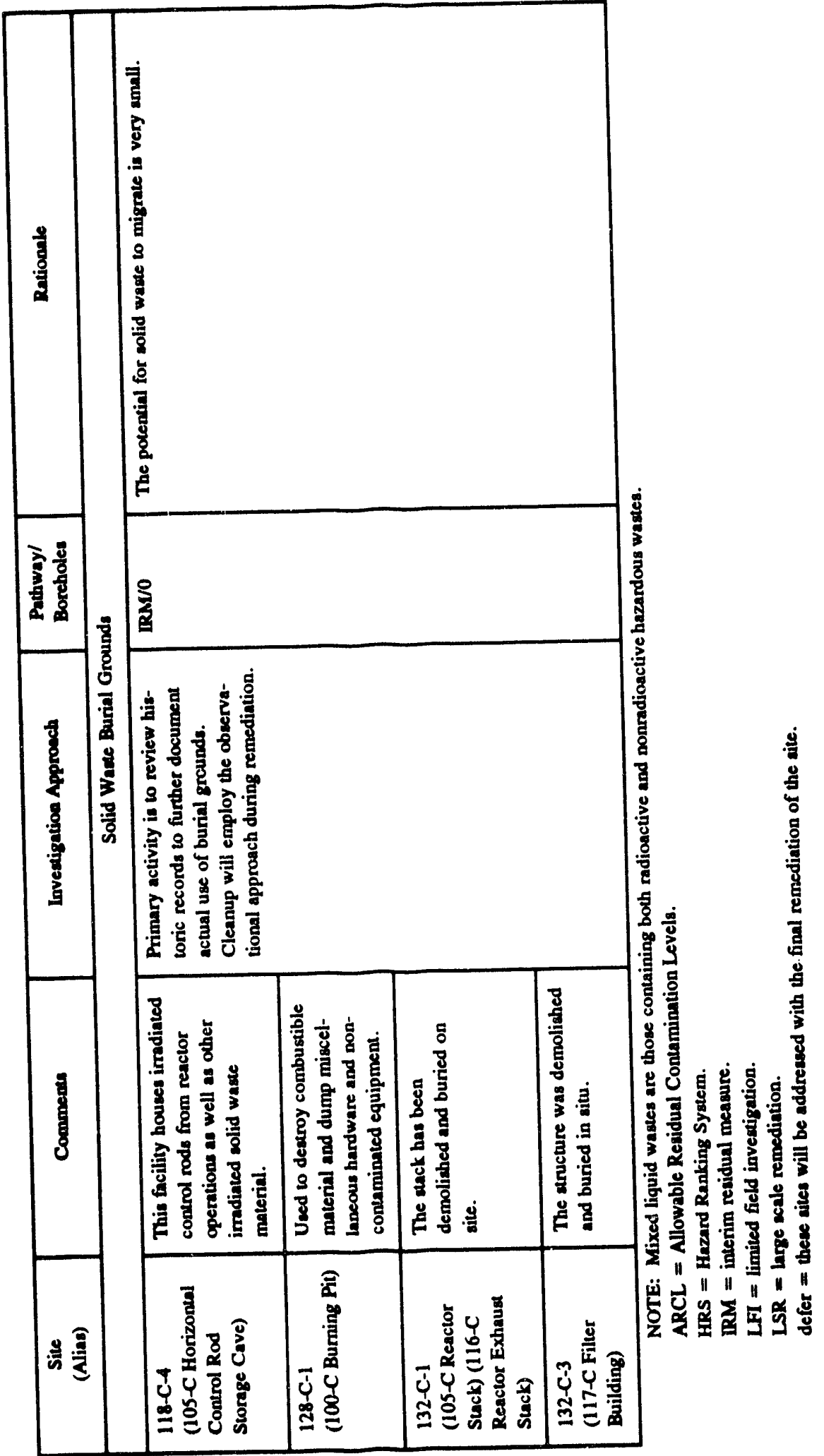

EST-1C 


\section{ACRONYMS AND ABBREVIATIONS}

CERCLA

DOE

DQO

Ecology

EPA

FS

IHMS

HRS

IRM

LFI

NPL

PCB

QAPjP

RCRA

RI

RL

Tri-Party

Agreement

TSD

WAC

WHC

WIDS
Comprehensive Environmental Response, Compensation, and Liability Act of 1980

U.S. Department of Energy

data quality objectives

State of Washington Department of Ecology

U.S. Environmental Protection Agency

feasibility study

Hanford Meteorological Station

Hazards Ranking System

interim remedial measures

limited field investigations

National Priorities List

polychlorinated biphenyls

quality assurance project plan

Resource Conservation and Recovery Act of 1976

remedial investr ation

DOE, Richland Field Office

Hanford Federal Facility Agreement and Consent Order

treatment, storage, and disposal

Washington Administrative Code

Westinghouse Hanford Company

Waste Information Data System 
DOE/RL-91-07, Rev. 0

\section{CONTENTS}

1.0 INTRODUCTION $\ldots \ldots \ldots \ldots \ldots \ldots \ldots \ldots \ldots$ WP $1-1$

1.1 PROJECT GOALS . . . . . . . . . . . . . W 1 WP

1.2 ORGANIZATION OF WORK PLAN $\ldots \ldots \ldots \ldots \ldots$ WP $1-2$

1.3 QUALITY ASSURANCE $\ldots \ldots \ldots \ldots \ldots \ldots \ldots$ WP $1-2$

2.0 OPERABLE UNIT BACKGROUND AND SETTING $\ldots \ldots \ldots \ldots$ WP 2-1

2.1 OPERABLE UNIT SITE DESCRIPTION . . . . . . . . . WP 2-1

2.1 .1 Location $\ldots \ldots \ldots \ldots \ldots \ldots \ldots \ldots \ldots$ WP 2-1

2.1.2 History of Operations $\ldots \ldots \ldots \ldots \ldots \ldots$ WP 2-1

2.1.3 Facility Identification $\ldots \ldots \ldots \ldots \ldots \ldots \ldots$ WP $2-2$

2.1.4 Waste-Generating Processes $\ldots \ldots \ldots \ldots \ldots \ldots \ldots$ WP $2-14$

2.1.5 Interactions with Other Operable Units $\ldots \ldots \ldots \ldots \ldots$ WP 2-21

2.1.6 RCRA Considerations . . . . . . . . . . . . . WP 2-21

2.2 PHYSICAL SETTING $\ldots \ldots \ldots \ldots \ldots \ldots \ldots \ldots \ldots$ WP $2-21$

3.0 INITIAL EVALUATION $\ldots \ldots \ldots \ldots \ldots \ldots \ldots$ WP $3-1$

3.1 KNOWN AND SUSPECI ED CONTAMINATION $\ldots \ldots \ldots$ WP 3-1

3.1 .1 Sources $\ldots \ldots \ldots \ldots \ldots \ldots \ldots \ldots$ WP $3-1$

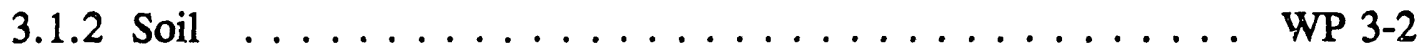

3.2 POTENTIAL ARAR . . . . . . . . . . . . . . WP 3-3

3.3 POTENTIAL IMPACTS TO HUMAN HEALTH AND

THE ENVIRONMENT $\ldots \ldots \ldots \ldots \ldots \ldots \ldots \ldots$ WP 3-4

3.3.1 Conceptual Exposure Pathway Model . . . . . . . . . WP 3-4

3.3.2 Preliminary Identification of Contaminants of Concern . . . W 3-7

3.3.3 Assessment of Need for ERA . . . . . . . . . . . . . WP 3-10

3.4 PRELIMINARY REMEDIAL ACTION OBJECTIVES

AND ALTERNATIVES $\ldots \ldots \ldots \ldots \ldots \ldots \ldots$ WP $3-11$

4.0 RATIONALE AND APPROACH $\ldots \ldots \ldots \ldots \ldots \ldots$ WP $4-1$

4.1 DQO PROCESS $\ldots \ldots \ldots \ldots \ldots \ldots \ldots \ldots \ldots$ WP $4-1$

4.1.1 Data Users . . . . . . . . . . . . . . . WP 4-2

4.1.2 Identification of Data Uses and Needs $\ldots \ldots \ldots \ldots \ldots$ WP 4-2

4.1.3 Design of Data Collection Program . . . . . . . . . . WP 4-4

4.2 INVESTIGATION STRATEGY . . . . . . . . . . . W WP 4-4

4.2.1 Hanford Site Past-Practice Strategy . . . . . . . . . . . WP 4-4

4.2.2 Investigation Strategy for the 100-BC-2 Operable Unit . . . WP 4-5

4.2.3 100-BC-2 Operable Unit Sampling and Analysis . . . . . . . WP 4-7

5.0 REMEDIAL INVESTIGATION/FEASIBILITY STUDY TASKS $\ldots \ldots$ WP 5-1

5.1 REMEDIAL INVESTIGATIONS $\ldots \ldots \ldots \ldots \ldots \ldots$ WP $5-1$

5.1.1 LFI and the 100 Aggregate Area and Hanford Site Studies . . . . . . . . . . . . . WP 5-1

5.1.2 Final Remedial Investigation $\ldots \ldots \ldots \ldots \ldots \ldots$ WP 5-9 
DOE/RL-91-07, Rev. 0

\section{CONTENTS (Cont)}

5.2 FEASIBILITY STUDIES $\ldots \ldots \ldots \ldots \ldots \ldots \ldots \ldots$ WP $5-9$

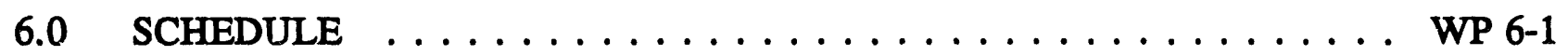

7.0 PROJECT MANAGEMENT $\ldots \ldots \ldots \ldots \ldots \ldots$ WP $7-1$

8.0 REFERENCES $\ldots \ldots \ldots \ldots \ldots \ldots \ldots \ldots \ldots \ldots \ldots$ WP 8 .1

\section{APPENDIXES:}

A QUALITY ASSURANCE PROJECT PLAN $\ldots \ldots \ldots \ldots \ldots \ldots \ldots$ A-1

B HEALTH AND SAFETY PLAN $\ldots \ldots \ldots \ldots \ldots \ldots \ldots$ B-1

C INFORMATION MANAGEMENT OVERVIEW $\ldots \ldots \ldots \ldots \ldots$ C-1

\section{FIGURES:}

1-1 Hanford Site $\ldots \ldots \ldots \ldots \ldots \ldots \ldots \ldots \ldots \ldots \ldots \ldots \ldots$ WP $1 F-1$

1-2 $100-$ BC-2 Area . . . . . . . . . . . . . . . . . . WP 1F-2

1-3 Hanford Site Past-Practice RI/FS (RFI/CMS) Process for the 100 Area . WP 1F-3

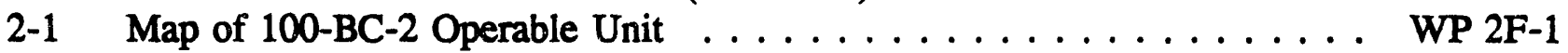

2-2 Top View of 116-C-2 Pluto Crib System $\ldots \ldots \ldots \ldots \ldots \ldots$ WP 2F-2

2-3 Side View of $116-\mathrm{C}-2$ Pluto Crib System $\ldots \ldots \ldots \ldots \ldots \ldots \ldots$ WP 2F-3

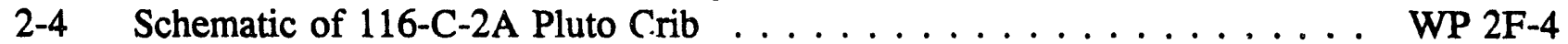

2-5 Schematic of 116-C-2B Pump Station $\ldots \ldots \ldots \ldots \ldots \ldots \ldots \ldots$ WP 2F-5

2-6 Schematic of 116-C-2C Sand Filter . . . . . . . . . . . . WP 2F-6

2-7 Sampling Locations at $116-C-2$ Pluto Crib System . . . . . . . . . . . WP 2F-7

2-8 Piping Schematic: Process Sewer and Cooling Water . . . . . . . . . WP 2F-8

2-9 Conceptual Hydrostratigraphic Column for the 100-B/C Area . . . . . WP 2F-9

2-10 Map of the Monitoring Wells in the 100-B/C Area . . . . . . . . . WP 2F-10

2-11 Geologic and Well Construction Log 199-B9-1 . . . . . . . . . . WP 2F-11

2-12 Well Information Sheet for Well 199-B9-2 . . . . . . . . . . WP 2F-12

2-13 Well Information Sheet for Well 199-B9-3 . . . . . . . . . . . . WP 2F-13

2-14 Wind Roses for the Hanford Site . . . . . . . . . . . . . . . . WP 2F-14

3-1 Conceptual Model Exposure Pathways - Process Effluents . . . . . . WP 3F-1

3-2 Conceptual Model Exposure Pathways - Burial Grounds . . . . . . . . WP 3F-2

3-3 Matrix of Preliminary Interim Response Actions,

Technologies, and Process Options . . . . . . . . . . . . WP 3F-3

4-1 Final Remedy Selection Process . . . . . . . . . . . . . WP 4F-1

4-2 Investigations at High Priority Liquid Waste Sites $\ldots \ldots \ldots \ldots$ WP 4F-2 
DOE/RL-91-07, Rev. 0

\section{CONTENTS (Cont)}

4-3 Investigations at Lower Priority Liquid Waste Sites and

Solid Waste Facilities Where Data from Analog

Facilities are Used . . . . . . . . . . . . . . . . . WP 4F-3

4-4 Investigations at Decommissioned Facilities $\ldots \ldots \ldots \ldots \ldots \ldots$ WP 4 F-4

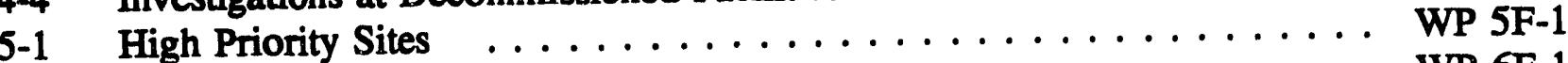

6-1 100-BC-2 Operable Unit Schedule $\ldots \ldots \ldots \ldots \ldots \ldots \ldots \ldots$ WP 6 F-1

\section{TABLES:}

2-1 Summary Description of Facilities/Potential Waste Sites

Located in the 100-BC-2 Operable Unit . . . . . . . . . . . . WP 2T-1

2-2 Summary of Concentrations and Inventories of Radiological

Contamination at the 100-BC-2 Operable Unit Waste Units . . . . . . WP 2T-2

2-3 116-C-2A Pluto Crib System Radiological Sampling Results ...... . WP 2T-3

2-4 132-C-1 Reactor Exhaust Stack Core Sample Analytical Data $\ldots \ldots$ WP 2T-4

3-1 Hanford Site Background Summary Statistics and Upper

Threshold Limits for Inorganic Analytes . . . . . . . . . . . . . . WP 3T-1

4-1 Investigative Approach for the 100-BC-2 Operable Unit $\ldots \ldots \ldots \ldots$ WP 4T-1

4-2 Data Needs Summary for the 100-BC-2 Operable Unit $\ldots \ldots \ldots \ldots$ WP 4T-2

4-3 Data Quality Objectives for the 116-C-2A Pluto Crib LFI . . . . . . . WP 4T-3

4-4 Data Quality Objectives for the 116-C-2C Pluto Crib

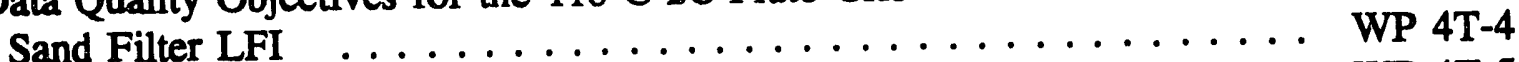

4-5 Analagous Sites for the 100-BC-2 Operable Unit $\ldots \ldots \ldots \ldots \ldots$ WP 4T-5

5-1 100-BC-2 Operable Unit Data Gaps $\ldots \ldots \ldots \ldots \ldots \ldots \ldots \ldots$ WP 5 T-1

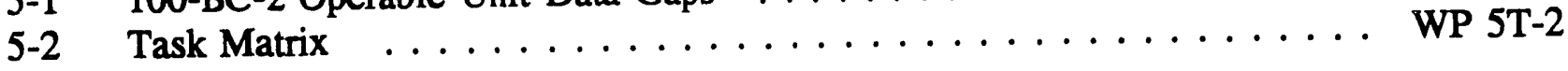




\subsection{INTRODUCTION}

This work plan and the attached supporting project plans establish the operable unit setting and the objectives, procedures, tasks, and schedule for conducting the Comprehensive Environmental Response, Compensation, and Liability Act of 1980 (CERCLA) remedial investigation/feasibility study (RI/FS) for the 100-BC-2 operable unit at the Hanford Site (Figure 1-1). The 100-BC-2 operable unit is one of two source operable units in the 100-B/C Area (Figure 1-2). The 100 Area is one of four areas at the Hanford Site that are on the U.S. Environmental Protection Agency's (EPA) National Priorities List (NPL) under CERCLA. Source operable units are those that contain facilities and unplanned release, sites that are potential sources of hazardous substance contamination. The groundwater affected or potentially affected by the entire $100-\mathrm{B} / \mathrm{C}$ Area is considered separately as the $100-\mathrm{BC}-5$ groundwater operable unit. A separate work plan has been issued for the $100-\mathrm{BC}-5$ operable unit (DOE-RL 1992b).

All work conducted under this work plan will conform to the conditions set forth in the Hanford Federal Facility Agreement and Consent Order (Tri-Party Agreement) (Ecology et al. 1990a), and its amendments, signed by the Washington Department of Ecology (Ecology), EPA, and the U.S. Department of Energy (DOE). In accordance with the Tri-Party Agreement, relevant guidance documents were consulted in the preparation of the work plan, including the following:

- Guidance for Conducting Remedial Investigations and Feasibility Studies Under CERCLA (EPA 1988)

- Data Quality Objectives for Remedial Response Activities (CDM Federal Programs Corporation 1987)

- $\quad$ Hanford Site Baseline Risk Assessment Methodology (DOE-RL 1993).

The approach for this work plan is based on the Hanford Site Past-Practice Strategy (DOE-RL 1991a). This strategy streamlines the past-practice remedial action process with a bias for action through optimizing the use of interim actions. This approach culminates with decisions of final remedies on both an operable unit and 100 Area scale. The strategy focuses on reaching early decisions to initiate and complete cleanup projects, maximizing the use of existing data, coupled with focused, short time-frame investigations, where necessary.

The RI/FS process using this strategy is a continuum of activities whereby the effort is defined based on knowledge gained as work progresses (the observational approach). Figure 1-3 displays the general organization of the past-practice strategy.

This chapter sets forth the general purpose, scope, and goals of the project. To avoid repetition with preceding documents (i.e., other work plans) and create a more site-specific work plan, generalities regarding processes, strategies, and background information are referred to the Remedial Investigation/Feasibility Study Work Plan for the 100-BC-1 Operable 
Unit, Hanford Site, Richland, Washington (DOE-RL 1992a) and the Remedial Investigation/Feasibility Study Work Plan for the 100-BC-5 Operable Unit, Hanford Site, Richland, Washington (DOE-RL 1992b).

\subsection{PROJECT GOALS}

The goal of the 100-BC-2 operable unit RI/FS is to provide sufficient information to optimize the use of interim remedial measures (IRM) that expedite cleanup, while maintaining a technically sound and cost-effective program of investigations that culminates in the development and evaluation of remedial alternatives in the final FS.

\subsection{ORGANIZATION OF WORK PLAN}

This work plan is organized in the same manner as the 100-BC-1 operable unit work plan, but is utilizing the philosophy of incorporation by reference. The scope of the work plan remains the same, but information that is not specific to the 100-BC-2 operable unit is referenced to either the 100-BC-1 (DOE-RL 1992a) or 100-BC-5 (DOE-RL 1992b) operable unit work plans.

\subsection{QUALITY ASSURANCE}

The 100-BC-2 operable unit work plan and its supporting project plans have been develsped to meet specific EPA guidelines for format and structure, within the overall quality assurance (QA) program structure mandated by DOE, Richland Field Office (RL) for all activities at the Hanford Site. The 100-BC-2 source operable unit quality assurance project plan (QAPjP) (Appendix A) supports the field sampling program for the $100-\mathrm{BC}-2$ operable unit. The QAPjP defines the specific means that will be used to ensure that the sampling and analytical data obtained as part of the limited field investigation (LFI) are of sufficient quality. The LFI and aggregate area studies will effectively support the purposes of the investigation. As required by the Westinghouse Hanford Company (WHC) QA program plan for RI/FS activities (WHC 1990) and the Tri-Party Agreement, the structure and content of the QAPjP are based on Interim Guidelines and Specifications for Preparing Quality Assurance Project Plans (Stanley and Verner 1983). Where required, the QAPjP invokes appropriate procedural controls selected from those listed in the WHC QA program plan for RI/FS activities or developed to accommodate the unique needs of this investigation. 
DOE/RL-91-07, Rev. 0

Figure 1-1. Hanford Site.

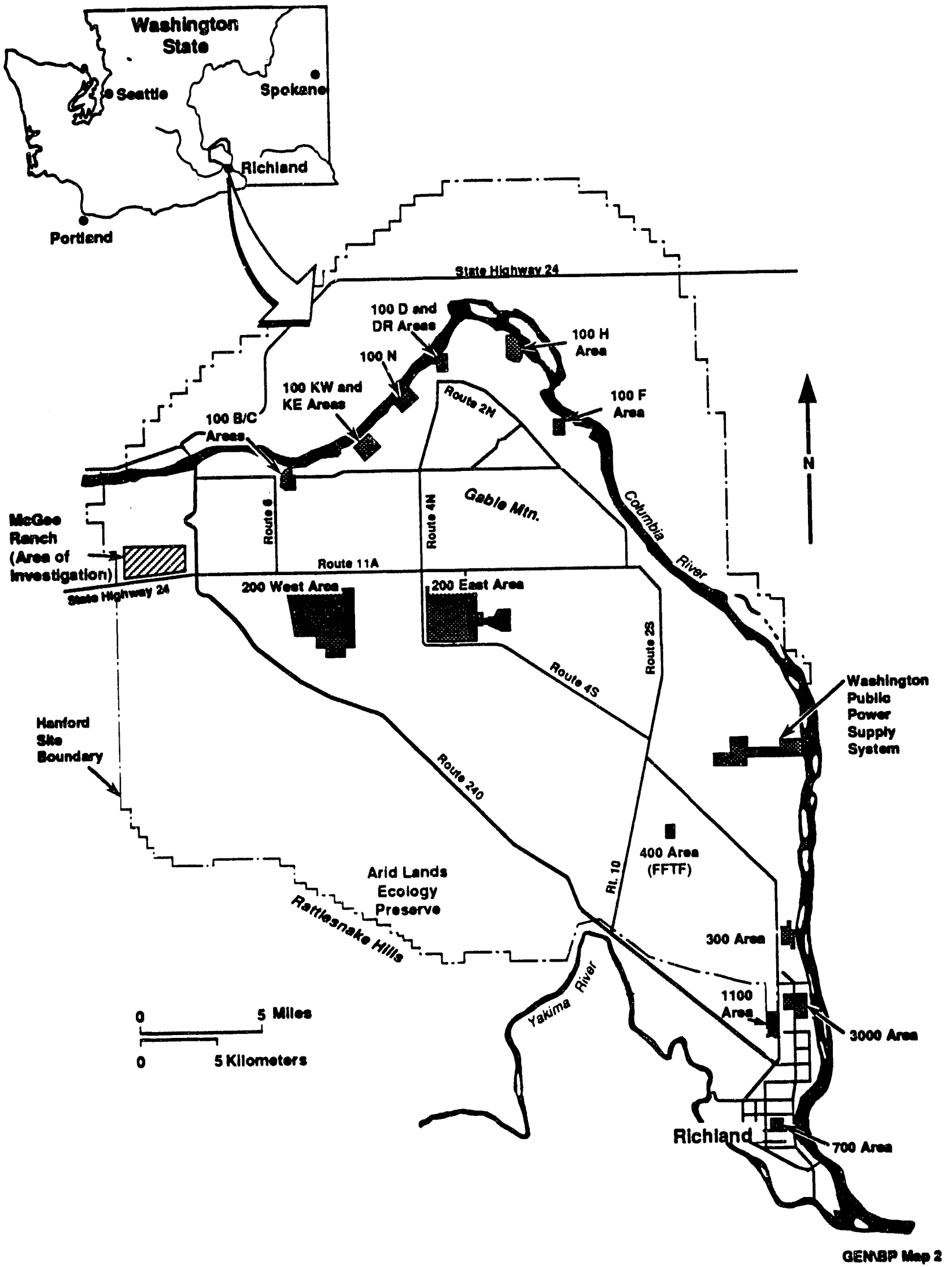




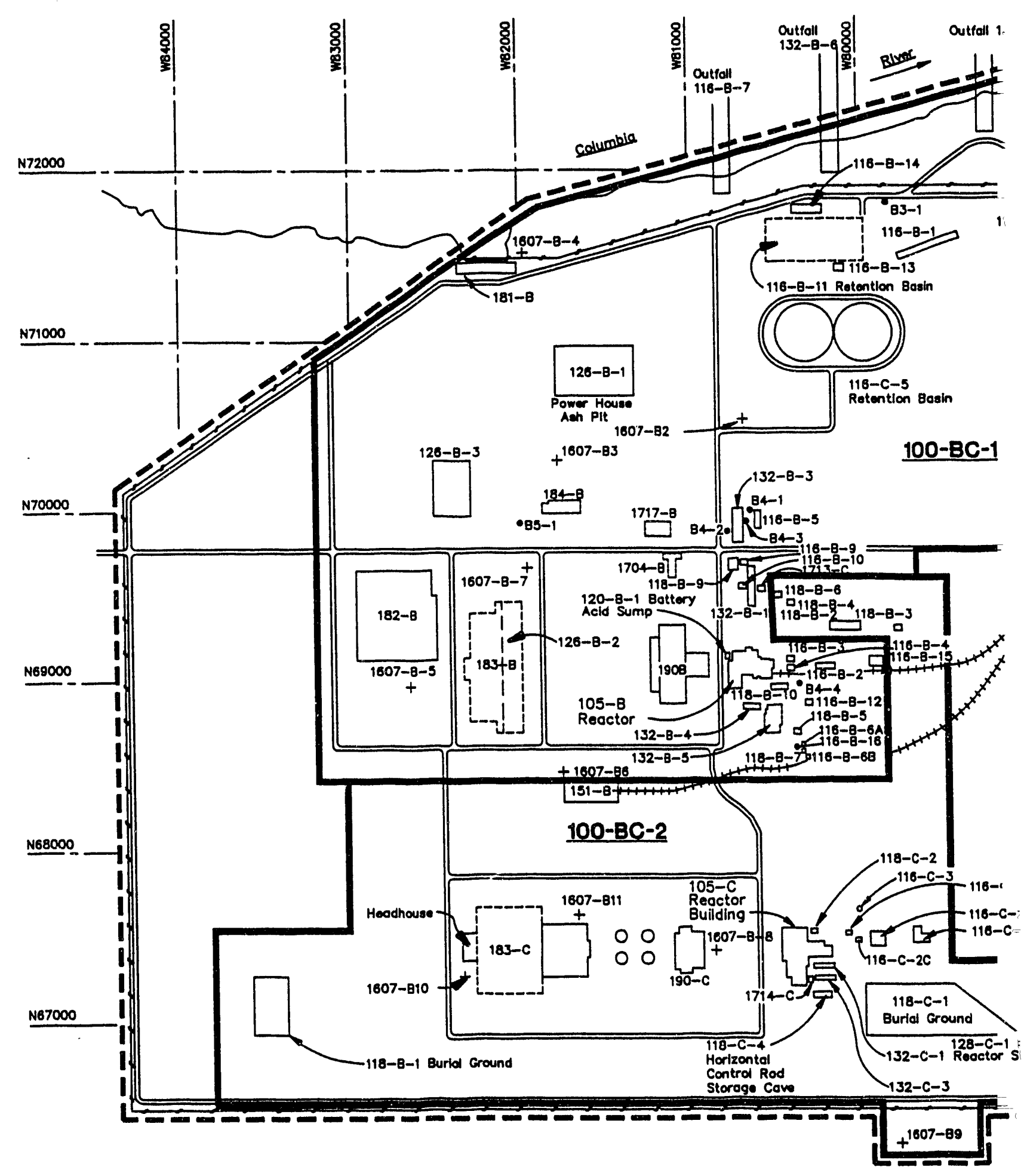

KOK\121192-8 


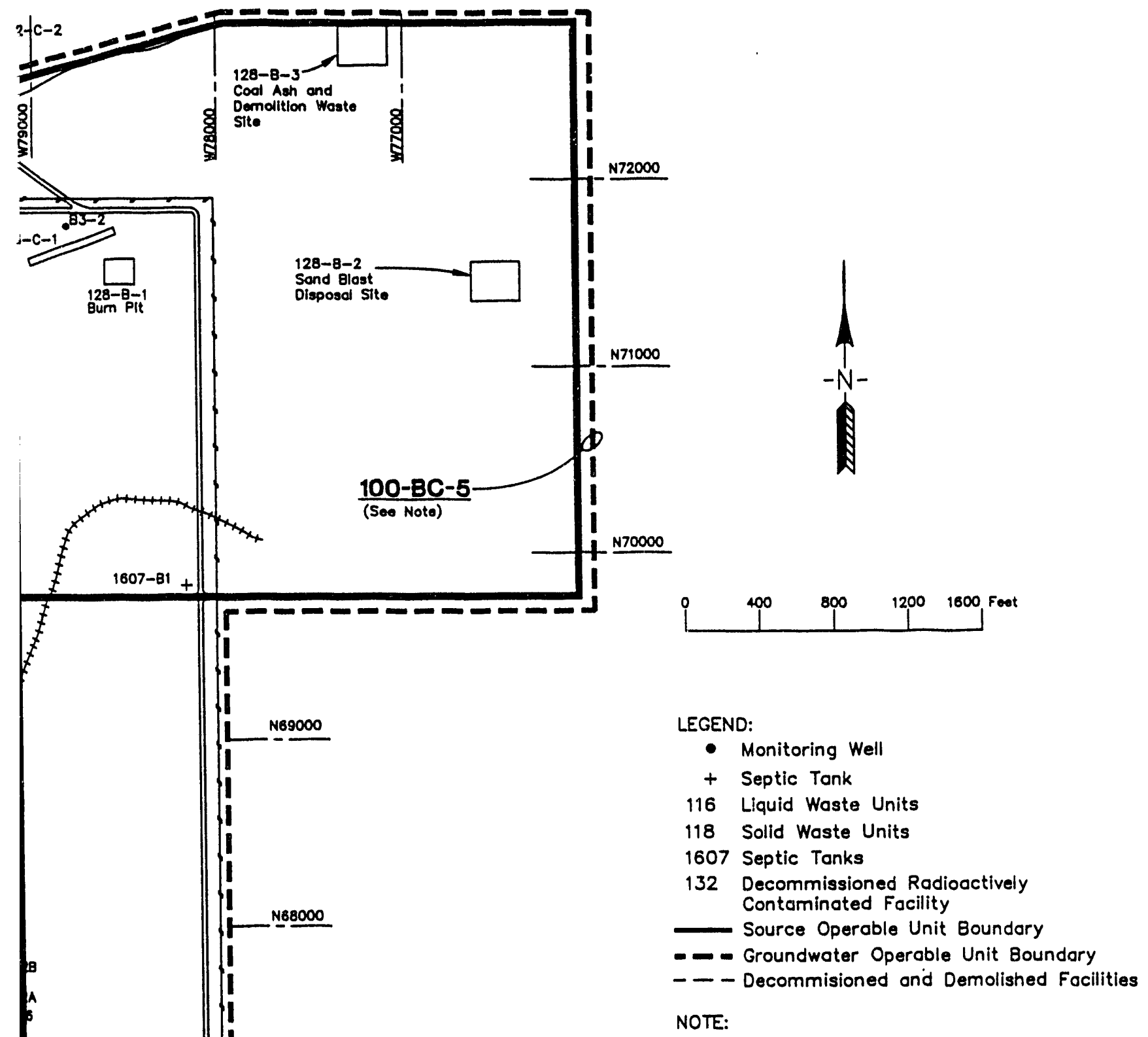

The heovy dashed line indicates the preliminary limits of the $100-B C-5$ operable unit.

Figure 1-2. 100-B/C Arca. 


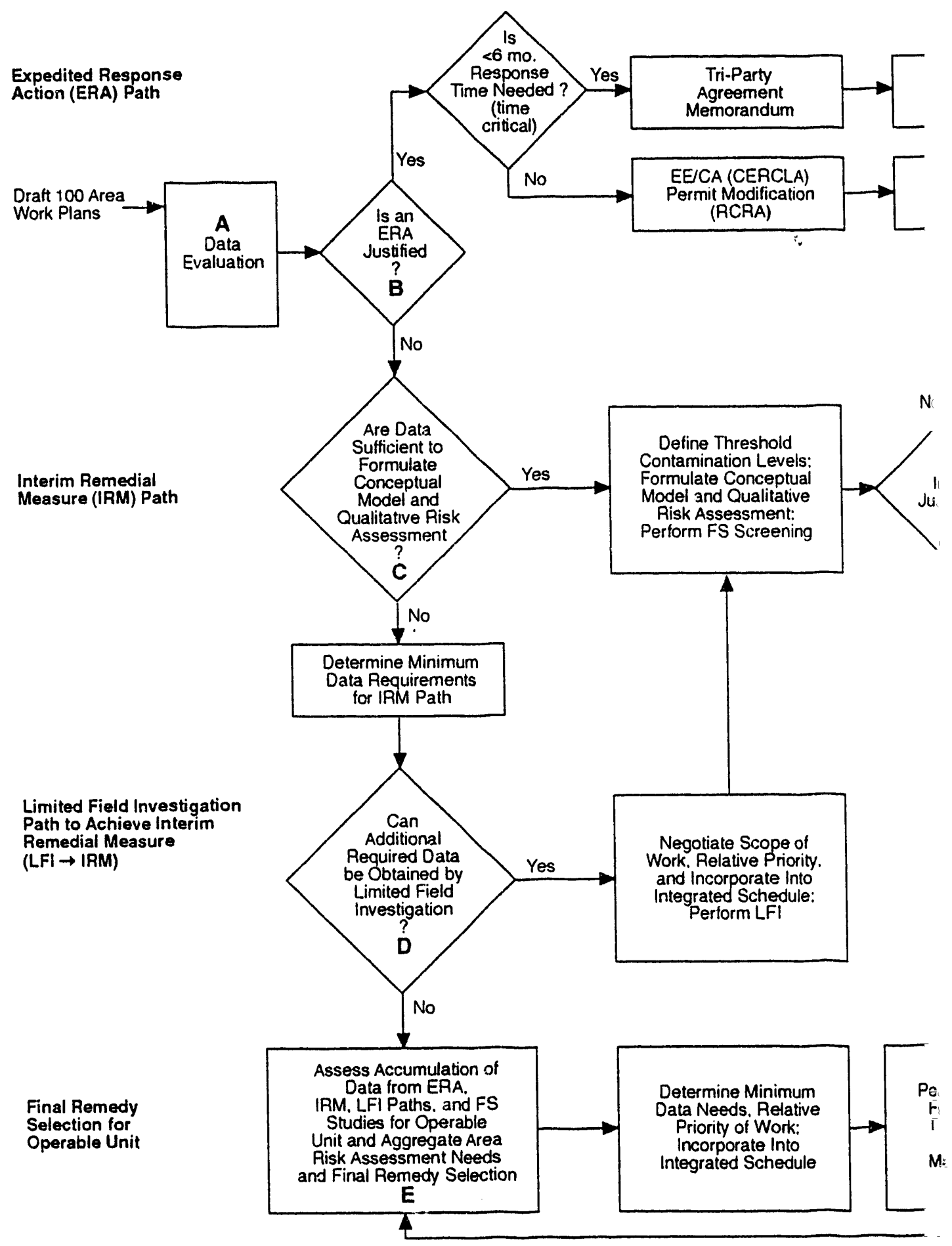

Source: Thompson 1991. 


\subsection{OPERABLE UNIT BACKGROUND AND SETTING}

This chapter presents a summary, based on currently available data, of the pertinent physical, historical, and biological settings for the 100-BC-2 operable unit. The available chemical and radiological data representing the known and suspected nature and extent of contamination, as well as the background conditions of the local environmental media, are also presented.

\subsection{OPERABLE UNIT SITE DESCRIPTION}

The 100-BC-2 operable unit is one of three operable units associated with the $100-\mathrm{B} / \mathrm{C}$ Area of the DOE's Hanford Site as shown in Figure 1-2. The 100-BC-2 waste units are liquid, sludge, and solid waste disposal sites generally associated with operation of the $\mathrm{C}$ Reactor. The third operable unit, $100-\mathrm{BC}-5$, is the groundwater operable unit, which aidresses groundwater, surface water, and river sediments, and aquatic biota.

This section describes the location of the 100-B/C Area, the history of operations in the area, particularly $C$ Reactor operations, and the facilities and structures located in the $100-\mathrm{BC}-2$ operable unit with a discussion of contamination for each waste unit.

\subsubsection{Location}

The 100-B/C Area is situated in the north-central part of the Hanford Site along the southern shoreline of the Columbia River, approximately $45 \mathrm{~km}(28 \mathrm{mi})$ northwest of the city of Richland, Washington, as shown in Figure 1-1. The 100-B/C Area is the Hanford Site plutonium production area farthest upstream from Richland, Washington.

The geographical area associated with the 100-BC-2 operable unit is located immediately south of the $100-\mathrm{BC}-1$ operable unit. The $100-\mathrm{BC}-1$ operable unit is adjacent to the Columbia River shoreline. In general, the $100-\mathrm{BC}-2$ operable unit contains waste units associated with the original plant facilities constructed to support $C$ Reactor operation. Cooling water retention basin systems for both $B$ and $C$ reactors are within the $100-B C-1$ operable unit. Figure 1-2 shows the approximate boundaries of the 100-BC-2 operable unit as defined by the waste units it includes, and its location with respect to the other operable units. The boundary of the $100-\mathrm{BC}-2$ operable unit is defined by the coordinates on Figure 2-1.

\subsubsection{History of Operations}

2.1.2.1 Reactor Operations. Between 1943 and 1953, nine water-cooled, graphitemoderated plutonium production reactors were built along the Columbia River upstream from the Hanford town site. All nine of these reactors (B, C, D, DR, F, H, KE, KW, and N) have been retired from service and are under evaluation for decommissioning. 
The 100-B/C Area contains two reactors: the B Reactor associated with the 100-BC-1 source operable unit, and the $\mathrm{C}$ Reactor associated with the $100-\mathrm{BC}-2$ source operable unit. The C Reactor, constructed in 1951, operated from 1952 until 1969 when it was retired from service. The C Reactor shared some of the ancillary facilities constructed for the B Reactor, such as the river water pumphouse and reservoir and the inert gas system.

2.1.2.2 Post-Reactor Operation Activities. Currently, the only active facility within the boundaries of the 100-BC-2 operable unit is the 151-B electrical substation. To minimize the potential spread of radioactive isotopes from the reactors and associated facilities, DOE instituted a program of decontamination and decommissioning of buildings and facilities after the reactors were retired. The process is ongoing, and some of the structures in the 100-BC-2 operable unit have been decommissioned. In some cases, decommissioning has been limited to removing equipment, electrical hardware, piping, and other items from the buildings. In other cases, these internal components have been removed and the entire structure has been demolished, with the debris either buried on site or transported to a burial ground elsewhere on the Hanford Site.

\subsubsection{Facility Identification}

For ease of discussion, all of the $100-\mathrm{BC}-2$ operable unit waste facilities are allocated among the following general categories:

- Reactor building and associated disposal facilities

- $\quad$ Process effluent pipelines

- Contaminated reactor ancillary facilities

- Miscellaneous cribs and trenches

- Sewage transfer, treatment, and disposal facilities

- $\quad$ Support facilities

- Tanks and related facilities

- Electrical facilities

- Solid waste burial grounds.

Table 2-1 lists 100-BC-2 operable unit facilities and waste sites identified during the background research phase of this project. The background research included a source data compilation task for the 100-B/C Area, which involved a review of photographs, engineering drawings, reports, and a field visit. Each facility is listed on Table 2-1 by the appropriate Hanford Site Waste Information Data System (WIDS) (WHC 1991) site number, where assigned, with any alias names shown in parentheses, followed by facility name, years in 
service and present status, facility purpose, description, and waste received or handled. These facilities are shown on Figure 2-1.

Two primary numbering systems have been used in the $100-\mathrm{B} / \mathrm{C}$ Area, and several buildings, structures, and waste units have two number designations. Under the original Hanford Site numbering system, buildings, structures (such as river outfalls), and some waste handling units (such as the retention basins) were given a unique number (e.g., 105-C for the $\mathrm{C}$ Reactor). Most waste units were not assigned a unique number, but were instead referred to by the number of the nearby building (e.g., 105-C pluto crib). More recently, most of the waste units, and some buildings and structures were assigned site designation numbers (e.g., 116-C-2 for the 105-C pluto crib). Throughout this document, preference is given to the site designation number. The only exceptions to this are the 105-B and 105-C reactor buildings, which will be referred to as B Reactor and C Reactor, respectively.

The following sections describe the facilities and structures located in the $100-\mathrm{BC}-2$ operable unit. Waste-generating processes associated with these facilities and structures are described. Also described are the known and suspected contamination at these facilities, including waste inventories where data are available.

2.1.3.1 C Reactor and Associated Disposal Facilities. This category includes the $\mathrm{C}$ Reactor and facilities receiving effluents generated by reactor operations, decontamination activities, and fuel storage that were not discharged immediately to process effluent pipelines. Operation of $B$ and $C$ reactors was the source of much of the con-tamination in the $100-\mathrm{B} / \mathrm{C}$ Area. Facilities directly related to $\mathrm{C}$ Reactor include 116-C-2A pluto crib and asso:iated pump station (116-C-2B) and sand filter (116-C-2C).

2.1.3.1.1 C Reactor Building. This building houses the plutonium production reactor, which is no longer operational. The $\mathrm{C}$ Reactor building is located in the eastern portion of the $100-\mathrm{BC}-2$ operable unit. It is surrounded by a placarded chain-link security fence.

Along with most of the other facilities in the 100-BC-2 operable unit, the C Reactor was operated from 1952 through 1969. The building consists of the following:

- reactor moderator stack, an assembly of graphite blocks with channels for the process tubes, control rods, and other equipment

- $\quad$ process tubes that held the uranium metal fuel elements and provided channels for cooling water

- control rods, fuel handling equipment, monitoring equipment, and experimental test holes

- thermal and biological shields

- a welded steel-plate box that encloses the biological shield and served to confine the gas atmosphere within the reactor 
- reactor work areas, decontamination wash pad, instrument room, fuel examination facility, and laboratory

- an irradiated fuel storage basin (Dorian and Richards 1978).

The decommissioning of the C Reactor, along with the other retired reactors, is the subject of a final environmental impact statement (Du $\Xi$ 1992), and is not within the scope of this work plan.

Although the reactor itself is not considered part of the 100-BC-2 operable unit, information or the coittaminants associated with the reactor are presented to assist in waste identification. Radivauclide inventories for the reactor block and the fuel storage basin are presenied in Table 2-2. The reactor block contains the majority of the radioactivity associated with the facility, but the contaminants an: largely immobilized in activated metal and graphite. The fuel storage basin served as a collection, storage, and transfer facility for irradiated fuel clements. It is estimated to have contuined approximately $50,000 \mathrm{~kg}$ (55 tons) of contaminated sludge (Miller and Steffes 1987), which is currently stored in the adjacent transfer pits.

Other contuminated portions of the reactor facility are estimated to contain $<5 \%$ of the total facility activity (Miller and Steffes 1987). This includes the soil column under the fuel storage basin and reactor, which may be contaminated.

Since the radionuclide inventory of the $C$ Reactor has not been evaluated, it was based on characterization work at the DR Reactor (Miller and Steffes 1987). The inventory was adjusted for the design ieatures, materials inventories, and known operating conditions at C Reactor; the radionuclide ralues were adjusted to reflect radioactive decay to March 1985. A total activity of approximately $25,000 \mathrm{Ci}$ was estimated throughout the reactor block, with the majority of the activity contributed by tritium $\left({ }^{3} \mathrm{H}\right)$, carbon- $14\left({ }^{14} \mathrm{C}\right)$, cobalt $-60\left({ }^{60} \mathrm{Co}\right)$, and nickel-63 $\left({ }^{63} \mathrm{Ni}\right)$. One curie of plutonium-239 $\left.{ }^{39} \mathrm{Pu}\right)$ was estimated to be present in the block. In the fuel storage basin sluige, the total activity was estimated to be $<100 \mathrm{Ci}$, with the principal radionuclides being ${ }^{60} \mathrm{Co},{ }^{83} \mathrm{Ni}$, strontium-90 $\left({ }^{90} \mathrm{Sr}\right)$, cesium-137 $\left({ }^{137} \mathrm{Cs}\right)$, europium-152 $\left({ }^{152} \mathrm{Eu}\right)$, and ${ }^{154} \mathrm{Eu}$, plus $1.5 \mathrm{Ci}$ of ${ }^{239} \mathrm{Pu}$ and $0.5 \mathrm{Ci}$ of americium-241 $\left({ }^{241} \mathrm{Am}\right)$ (Miller and Steffes 1987).

The C Reactor included $105,000 \mathrm{~kg}$ (105 tons) of lead and approximately $200 \mathrm{~m}^{3}$ $\left(7,000 \mathrm{ft}^{3}\right)$ of asbestos (DOE-RL 1992c), plus mercury and caumium, which may contribute to potential contamination at the site. The mercury and some of the asbestos have already been removed (Miller and Steffes 1987). In addition, decontanination activities within the C Reactor building included use of chromic, citric, oxalic, nitric, sulfamic, and sulfuric acid solutions and sodium fluoride. Other chemicals, including organic solvents, were used for some decontamination processes. These decontamination wastes may have been disposed of in the $116-\mathrm{C}-2 \mathrm{~A}$ pluto crib.

2.1.3.1.2 116-C-2 Pluto Crib System. A pluw crib system was constructed near the C Reactor to receive the contaminated cooling water that was flushed directily from process tubes that were affected by fuel cladding failures (Figures 2-2 and 2-3). 
The pluto crib system consisted of three parts: the 116-C-2A pluto crib, the 116-C-2B pump station, and the 116-C-2C sand filter (Figure 2-2). The 116-C-2A crib was the largest pluto crib in the 100 Areas. It is an unlined structure 7 by 4.9 by $1.5 \mathrm{~m}$ deep (23

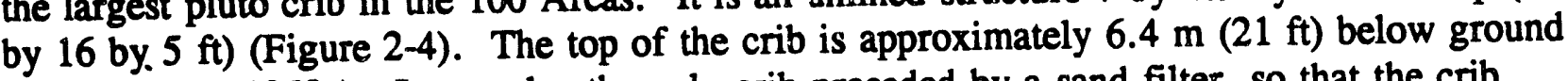
surface (AEC 1953a). It was also the only crib preceded by a sand filter, so that the crib actually received filtered effluent. The 116-C-2B pump station (Figure 2-4), 3.0 by 2.4 by $9.1 \mathrm{~m}$ deep ( 10 by 8 by $30 \mathrm{ft}$ ) pumped wastes from the $C$ Reactor building through a pipe into the 116-C-2C pluto crib sand filter (AEC 1953b). The 116-C-2C pluto crib sand filter consisted of an enclosed concrete box, 11.5 by $5.5 \mathrm{~m}$ by $5.5 \mathrm{~m}$ deep ( 38 by 18 by $18 \mathrm{ft}$ deep), filled with basalt sand (AEC 1953c) (Figure 2-6). The contaminated effluents were discharged to the sand filter through distributor trays, and excess effluent was then discharged through a pipe to the pluto crib (Dorian and Richards 1978). The sand filter is covered with concrete shielding slabs. It has not been documented that the sand filter was ever cleaned out.

In addition to waste from fuel cladding failures, the unlined $116-\mathrm{C}-2 \mathrm{~A}$ pluto crib was used until 1969 for soil-column disposal of other liquid waste discharges, and was apparently the primary liquid waste disposal site for all $\mathrm{C}$ Reactor operations. The principal effluents that were discharged to the pluto crib system included liquid wastes from the rear face of the $C$ Reactor, effluents from spacer and hardware decontamination done on the C Reactor building wash pad, and effluents from the irradiated fuel examination facility in the C Reactor building.

The nonradioactive wastes received by the 116-C-2A pluto crib includes $500 \mathrm{~kg}(1,100 \mathrm{lb})$ sodium dichromate, $1,000 \mathrm{~kg}(2,200 \mathrm{lb})$ sodium oxalate, and $1,000 \mathrm{~kg}$ $(2,200 \mathrm{lb})$ sodium sulfamate (DOE-RL $1992 \mathrm{c})$.

The three units of the 116-C-2 pluto crib system were sampled as part of the $1975 / 1976$ radiological study by Dorian and Richards (1978), at the locations indicated in Figure 2-7. Five borings from the soil column underlying the crib were obtained at depths up to $15 \mathrm{~m}(50 \mathrm{ft})$ below grade. Results are presented in Table 2-3. In the soil below the bottom of the crib, the average activities of ${ }^{90} \mathrm{Sr}$ and ${ }^{3} \mathrm{H}$ were 130 and $53 \mathrm{pCi} / \mathrm{g}$, respectively. Activities decrease by approximately an order of magnitude through that column. Other radionuclides present at lower concentrations were ${ }^{60} \mathrm{Co},{ }^{137} \mathrm{Cs},{ }^{152} \mathrm{Eu}$, and ${ }^{154} \mathrm{Eu}$. No plutonium was detected (Dorian and Richards 1978).

The sand filter bed was sampled by hand after removing the concrete lids. The soil adjacent to the sand filter was sampled at depths of up to $30 \mathrm{ft}(9 \mathrm{~m})$ below grade. The results are given in Table $2-3$. The principal radionuclides measured were ${ }^{60} \mathrm{Co},{ }^{90} \mathrm{Sr},{ }^{137} \mathrm{Cs}$, ${ }^{238} \mathrm{Pu}$, and ${ }^{239 / 240} \mathrm{Pu}$. Concentrations in the sand filter bed were as high as $1,600 \mathrm{pCi} / \mathrm{g}$ for ${ }^{238} \mathrm{Pu}, 1,500 \mathrm{pCi} / \mathrm{g}$ for ${ }^{239 / 240} \mathrm{Pu}$, and $7,100,000 \mathrm{pCi} / \mathrm{g}$ for ${ }^{60} \mathrm{Co}$. Concentrations in the soil below the bottom of the sand filter decreased to 7 to $9 \mathrm{pCi} / \mathrm{g}$ for ${ }^{239 / 240} \mathrm{Pu}$ and $490 \mathrm{pCi} / \mathrm{g}$ for ${ }^{60} \mathrm{Co}$. The total radionuclide inventory estimated for the contaminated filter and soil column was $0.12 \mathrm{Ci}$ of ${ }^{239 / 240} \mathrm{Pu}$ and $260 \mathrm{Ci}$ of ${ }^{60} \mathrm{Co}$ (Dorian and Richards 1978).

Three boreholes were placed into or adjacent to the $116-\mathrm{B}-6 \mathrm{~A}$ crib in the $100-\mathrm{BC}-1$ operable unit in 1989 and samples were analyzed for inorganics and radionuclides as part of 
the in situ vitrification demonstration project. Results of the analyses are presented in the 100-BC-1 work plan (DOE-RL 1992a). The crib received waste sodium dichromate, sodium oxalate, sodium sulfamate, and various radionuclides, which are similar to the types of waste suspected of being disposed of in the 116-C-2A pluto crib system in the 100-BC-2 operable unit. The results indicated that some metals are elevated and that contamination appears to mainly be within the confines of the crib (Luey et al. 1992).

2.1.3.2 Process Effluent Pipelines. Two process effluent pipelines emanate from the C Reactor building to the 116-C-5 retention basin located in the 100-BC-1 operable unit. The 1.7-m (5.5-ft) diameter lines, constructed of carbon steel, are still in place below the land surface (General Electric 1963). Figure 2-8 is a general schematic of the pipelines. A map displaying the exact locations of the effluent pipes is considered as a data gap.

The process effluent pipelines transported reactor coolant and some decontamination wastes from the $\mathrm{C}$ Reactor. Portions of these pipelines are known to have developed leaks at various times during their periods of operations (Dorian and Richards 1978). To date, no leaks have been identified in the 100-BC-2 operable unit. No sampling was conducted within the 100-BC-2 operable unit along any effluent lines emanating from the $\mathrm{C}$ Reactor. Dorian and Richards (1978) sampled the 105-C main diversion box in the 100-BC-1 operable unit by collecting rust and scale from the inlet pipeline to the east of the diversion box and rust, scale, and sludge from the center of the floor. The results of this sampling are presented in Table 2-2 (105-C diversion box). Significant underground contamination was identified in the vicinity of the B Reactor from past effluent line leakage by samples collected along a cross-tie line from the 105-B effluent line to a junction box in the 100-BC-1 operable unit (Dorian and Richards 1978). Sampling results are presented in the 100-BC-1 operable unit work plan (DOE-RL 1992a).

2.1.3.3 Contaminated Reactor Ancillary Facilities. This category includes all facilities involved with the secondary wastes from the $C$ Reactor building that may involve irradiated materials. Dorian and Richards (1978) surveyed for radiation levels at the 132-C-3 exhaust air filter building, the 132-C-1 reactor exhaust stack, and the gas recirculation piping tunnels associated with the 132-B-5 building. The 118-C-4 horizontal control rod storage cave is the only reactor ancillary facility for which there is no sampling information.

2.1.3.3.1 118-C-4 Storage Cave. This is a $12.2-$ by $7.6-\mathrm{m}$ (40- by $25-\mathrm{ft})$ storage site south of the C Reactor building, used at one time to temporarily store contaminated horizontal control rods for radioactive decay pending subsequent disposal. It is a concrete tunnel covered with a $1.2-\mathrm{m}(4-\mathrm{ft})$ thick mound of earth. It is suspected to contain miscellaneous reactor facility components (DOE-RL 1992c). Contaminant inventories for the storage cave have not been estimated, but the principal radionuclides in irradiated control rods are ${ }^{60} \mathrm{Co}$ and ${ }^{63} \mathrm{Ni}$ (Dorian and Richards 1978). The radiation reading at the entrance to the tunnel is $5 \mathrm{mrem} / \mathrm{h}$ (DOE-RL 1992c).

2.1.3.3.2 132-C-1 Reactor Exhaust Stack. The 132-C-1 reactor stack received exhaust air from the 132-C-3 exhaust air filter building. Prior to completion of the 132-C-3 exhaust air filter building in 1960, exhaust air flowed through concrete ducts from the $\mathrm{C}$ Reactor building directly into the $132-\mathrm{C}-1$ exhaust stack. Following completion of the 
132-C-3 air filtration project, the air was diverted via underground, reinforced-concrete ducts to the 132-C-3 filter building. After flowing through the filters, the air went through belowgrade and abovegrade concrete ducts into the exhaust stack. The stack was $61 \mathrm{~m}$ $(200 \mathrm{ft})$ high, with a base $5.1 \mathrm{~m}(16.6 \mathrm{ft})$ in diameter. It was constructed of reinforcedconcrete with a maximum wall thickness of $0.46 \mathrm{~m}(1.5 \mathrm{ft})$ at the base. The stack was demolished in 1985 into a trench $5.5 \mathrm{~m}$ (18 ft) deep, $9.1 \mathrm{~m}$ ( $30 \mathrm{ft})$ wide, and $61 \mathrm{~m} \mathrm{(200 \textrm {ft } )}$ long. The location of the disposal site is in Figure 1-2.

Samples were obtained from the stack inlet in 1976 using standard smear techniques. They indicated that the stack was contaminated with low levels of beia and gamma radiation activity. Concentrations were $1.1 \mathrm{pCi} / 100 \mathrm{~cm}^{2}$ and $21 \mathrm{pCi} / 100 \mathrm{~cm}^{2}$ of ${ }^{238} \mathrm{Pu}$ and ${ }^{239240} \mathrm{Pu}$, respectively (Dorian and Richards 1978 ). Cobalt-60, ${ }^{90} \mathrm{Sr}$, and ${ }^{137} \mathrm{Cs}$ were detected at levels between 300 and $1,000 \mathrm{pCi} / 100 \mathrm{~cm}^{2}$ in the smears. Results are shown in Table 2-2.

Concrete core samples were collected and analyzed prior to demolition (Beckstrom 1986). A total of five 10-cm (4-in.) core samples were obtained: one core sample each from the $2.7-\mathrm{m}(9-\mathrm{ft}), 7.6-\mathrm{m}(25-\mathrm{ft})$, and $18.3-\mathrm{m}(60-\mathrm{ft})$ elevations, and two core samples from the $12-\mathrm{m}(40-\mathrm{ft})$ elevation. The sampling results are presented in Table $2-4$. The interior of the stack was coated with approximately $8 \mathrm{~mm}(0.3 \mathrm{in})$ of tar. With the exception of the ${ }^{90} \mathrm{Sr}$ results in core sample number 5 , each core sample showed highest activity in the first two layers. The total radionuclide inventory in the buried rubble is estimated by Beckstrom (1986) to be $2.8 \mathrm{mCi}$.

2.1.3.3.3 132-C-3 Exhaust Air Filter Building. The $C$ Reactor building exhaust air filters and air flow control systems were housed in the 132-C-3 building. Reactor exhaust gases passed through particulate and activated charcoal filters before being discharged to the atmosphere through the 132-C-1 reactor exhaust stack.

The 132-C-3 building was mostly constructed of concrete with two identical filter cells. The building was 18.0 by 11.9 by $10.7 \mathrm{~m}$ high ( 59 by 39 by $35 \mathrm{ft}$ ). Only $2.4 \mathrm{~m}$ $(8 \mathrm{ft})$ of the building was abovegrade. The 132-C-3 building, constructed in approximately 1960 , was decontaminated before it was demolished. The building was partially demolished in 1984 and completely demolished in 1988.

2.1.3.3.4 Gas Recirculation System Piping Tunnels. The gas recirculation system piping tunnels are located between the 132-B-5 gas recirculation building (demolished in 1988), which was located within the 100-BC-1 operable unit, and the C Reactor building. The piping tunnel dimensions are approximately 11.0 by $2.4 \mathrm{~m} \mathrm{(36}$ by $8 \mathrm{ft}$ ) (Dorian and Richards 1978). The purpose of the inert gas system was to provide a nonreactive gas environment in the graphite core that would remove moisture and gases from the core and serve as a heat transfer medium between the graphite core and the process tubes. A mixture of helium and carbon dioxide, driven at low pressure by a blower system located in the 132-B-5 gas treatment facility, was circulated through the graphite pile. Filters, gas coolers, blowers, condensers, and silica gel drying towers were located in the 132-B-5 building. The system was designed to maintain a slight positive pressure in the reactor with respect to the circulating gas so that the inert gas could not make contact with the graphite core. When a leak was detected, the gas was routed to the ventilation exhaust system. The construction 
details and exact location of the piping tunnels need to be determined. Dorian and Richards (1978) sampled the piping tunnels and the results are presented in Table 2-2 (132-B-5 Gas Recirculation Piping Tunnels).

2.1.3.4 Miscellaneous Ponds, Cribs and Trenches. No cribs or trenches have been specifically identified in the $100-\mathrm{BC}-2$ operable unit other than the 116-C-2A pluto crib discussed previously. The $116-\mathrm{C}-6$ pond received effluent from the $\mathrm{C}$ Reactor fuel storage basin. The unlined pond received $1,866,208 \mathrm{~L}(493,000 \mathrm{gal})$ of treated water from the fuel storage basin within the $C$ Reactor building in 1985. The specifics on the temporary pumping and treatment of the basin water is described by Dement (1988). The pond is " $\mathrm{L}$ " shaped and has an uneven depth averaging approximately $1.8 \mathrm{~m}(6 \mathrm{ft})$. The dimensions in a clockwise direction, beginning in the southeast corner, are 30.5 by 30.5 by 15.2 by 16.8 by 15.2 by $13.7 \mathrm{~m}$ ( 100 by 100 by 50 by 55 by 50 by $45 \mathrm{ft}$ ) (Dement 1988).

The pond was sampled at $15.3-\mathrm{cm}$ (6-in.) depths at 23 locations. The average results are presented in Table 2-2 (116-C-6 pond), and detailed results are provided by Dement (1988). Water was sampled prior to the release to the pond to verify that predetermined decommissioning allowable residual contamination levels (ARCL) had been met. Further radiological controls are considered unnecessary as reported by Dement (1988), because the discharge into the 116-C-6 Pond was an unrestricted release. An unrestricted release means that residual soil contamination is below unrestricted release levels for dispersed activity (Dement 1988).

2.1.3.5 Sewage Transfer, Treatment, and Disposal Facilities. Sanitary sewage generated at the 100-BC-2 operable unit was treated in underground septic tanks and subsequently discharged to associated drain fields. There is no documentation of hazardous wastes being disposed of in any of these facilities. Four septic tanks and associated drain fields have been identified. Industrial waste water from the cooling water treatment facilities was disposed through a process sewer pipeline with an outlet to the Columbia River.

The four septic tanks and drain fields received sanitary sewage from the 183-C head house, 183-C filter building, the C Reactor, and the 190-C pump house. The process sewer received waste water from the 183-C water treatment facility and the 190-C pumphouse. No sampling information exists for any of these facilities.

2.1.3.5.1 Septic Tanks and Drain Fields. The 1607-B8 septic tank and drain field received sanitary sewage from the 190-C pumphouse (DOE-RL 1992c). The 1607-B9 septic tank located south east of the $C$ Reactor received sanitary sewage from the $C$ Reactor building. The 1607-B10 septic tank is located west of the 183-C filter building received sanitary sewage from the 183-C head house. The 1607-B11 tank is north of the 183-C filter building and received sanitary sewage from that building. Architectural drawings of the septic systems show the exact locations of the tanks and drain fields (AEC M-1904-B, sheet 8 and 9). The general locations are indicated in Figure 2-1.

2.1.3.5.2 Process Sewer Pipeline. A process sewer pipeline is shown on several engineering drawings. Access holes for this process sewer were observed during a site visit. The process sewer line consists of two adjacent 1.2 - by $1.8-\mathrm{m}(4-$ by $6-\mathrm{ft})$ flumes aligned 
west to east from the 183-C filter building to the $\mathrm{C}$ Reactor building and then in a northern direction to the 132-B-2 outfall structure in the 100-BC-1 operable unit (Figure 2-4).

2.1.3.6 Support Facilities. Primary reactor operations support facilities included the 183-C water treatment facility, four water storage tanks, and the 190-C pump house, which were part of the cooling water system that prevented damage to the $\mathrm{C}$ Reactor core from excess heat generated by the fission reactions (Figure 2-4). Other support facilities within the $100-\mathrm{BC}-2$ operable unit include the $1702-\mathrm{C}$ badge house, the $1714-\mathrm{C}$ solvent storage building, and the 1736-C storage building.

The disposal locations of any sludges produced from the water treatment process are currently unknown. Another potentially contaminated support facility within the operable unit include the 1714-C solvent storage building. No sampling information exists for this facility.

2.1.3.6.1 183-C Water Treatment Facility. At the 183-C water treatment facility, river water was treated with chemical additives and filtered. The facility consisted of a $141 \mathrm{~m}^{2}\left(1,520 \mathrm{ft}^{2}\right)$ reinforced concrete head house and chemical building for chemical makeup and addition, a basin equipped with paddle wheel flocculators, eight open-air settling basins, a $8,454-\mathrm{m}^{2}\left(91,000 \mathrm{ft}^{2}\right)$ reinforced-concrete filter building to house filter beds, and two 11-million L (3-million gal) clearwells. Portions of the building were demolished in 1988 , and only the concrete filter building and the clearwells are now standing.

The potential for contamination exists in the vicinity of the 183-C head house where chemicals were used as part of the water treatment process. Chemicals used at this location include hydrated calcium oxide, chlorine, and sulfuric acid.

2.1.3.6.2 190-C Main Pump House. The 190-C main pump house contains the electrically driven pumps that were used for providing the primary cooling water to the C Reactor. It consists of a single-story, 59.7 - by $55.8-\mathrm{m}$ (196- by $183-\mathrm{ft})$ reinforcedconcrete structure. To the west of the 190-C pumphouse were four steel water storage tanks with a storage capacity of 20 million L (5.25 million gal) each. These four tanks have been removed. The 190-C pumphouse pumped cooling water from the water storage tanks to a valve pit in the C Reactor building (General Electric 1963).

A site visit revealed that the $190-\mathrm{C}$ pumphouse is posted with radiation, potentially hazardous materials, and no smoking warning signs. The 190-C building is being used for storage of contaminated lead and equipment from $\mathbf{N}$ Reactor and also houses four aboveground storage tanks apparently used to store sodium dichromate.

2.1.3.6.3 Other Support Facilities. The 1702-C badge house, located west of the C Reactor building, is a $20 \mathrm{~m}^{2}\left(210 \mathrm{ft}^{2}\right)$ wooden frame building with asbestos shake siding that provided entrance to the $\mathrm{C}$ Reactor exclusion area. The 1714-C solvent storage building is located on the southeast corner of the $C$ Reactor. The building has a steel frame with transite siding and a concrete foundation. The $1714-\mathrm{C}$ is approximately 156 square feet. No sampling information exists for the $1714-\mathrm{C}$ building. The $1736-\mathrm{C}$ building was a sheet metal 
building used to store maintenance tools and equipment. The $6.1-$ by $12.2-\mathrm{m}$ (20- by $40-\mathrm{ft})$ concrete pad for the 1736-C building still remains east of the $\mathrm{C}$ Reactor building.

2.1.3.7 Tanks and Related Facilities. Tanks that have been identified in the 100-BC-2 operable unit include the 116-C-3 storage tanks/chemical waste tanks, the 118-C -2 Ball $3 \mathrm{X}$ storage tank, and the location of former aboveground chemical storage tanks at the 183-C headhouse.

Two 116-C-3 storage tanks/chemical waste tanks, located northeast of the C Reactor building, were originally intended to store liquid waste from the fuel examination facility, which had access to the $\mathrm{C}$ Reactor fuel storage basin. The combined capacity of the tanks was $102,000 \mathrm{~L}(27,000 \mathrm{gal})$. The tanks were never used because the $116-\mathrm{C}-2 \mathrm{~A}$ pluto crib became available (DOE-RL 1992c).

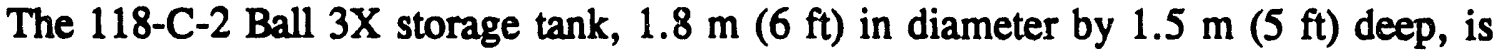
buried in the ground under a shielding mound approximately $0.6 \mathrm{~m}(2 \mathrm{ft})$ above ground level. Two visible standpipes are present.

The 118-C-2 Ball 3X storage tank contains approximately 10 tons $(9,070 \mathrm{~kg})$ of highly activated boron steel (70\% of total) and carbon steel (30\% of total) balls. The 9.5-mm (0.375-in.) diameter balls, called $3 \mathrm{X}$ balls, were designed for emergency shutdown of the reactors. The $3 \mathrm{X}$ balls in this particular tank were generated during feasibility testing of a "hot" ball sorter prototype and had been previously irradiated. A 1987 evaluation estimated that the tank contains $80 \mathrm{Ci}$ of ${ }^{60} \mathrm{Co}$ and $1.6 \mathrm{Ci}$ of ${ }^{63} \mathrm{Ni}$ (Miller and Wahlen 1987). Information related to the decontamination of the boron balls is considered a data gap.

A field visit revealed the presence of concrete structures on the western margin of the demolished 183-C head house that may have supported aboveground tanks. These tanks may have contained hydrated calcium oxide, chlorine, and/or sulfuric acid. No other tanks have been identified within the $100-\mathrm{BC}-2$ operable unit.

2.1.3.8 Electrical Facilities. This category includes the 151-B primary substation, individual building substations, and the electrical distribution system with the associated transformers, capacitors, switches, and other miscellaneous electrical facilities within the 100-BC-2 operable unit. The main substation (151-B) for the $100 \mathrm{~B} / \mathrm{C}$ Area is located within $100-B C-2$ operable unit. This substation is currently supplying power to the export water system and some decommissioned facilities. Building substations are also located at the 183-C filter building, the 190-C pumphouse, and the C Reactor building. A distribution system ties the 151-B substation to the building substations.

The potential exists for polychlorinated biphenyls (PCB) contamination in soils where oil-filled electrical equipment was located. PCB electrical equipment are managed by WHC electric utilities. The utility administrator maintains a database of all PCB-contaminated electrical equipment. Historic records for spill cleanup and equipment disposal are also kept by the Electric Utilities. Recent electrical facility sampling data were generated during an investigation associated with the $100-\mathrm{BC}-1$ operable unit. These data will be useful in determining the possible contamination from electrical facilities associated with the $100-\mathrm{BC}-2$ 
operable unit since some of the sampling locations are located with in its boundaries. The exact location of all electrical substations is considered a data gap.

2.1.3.9 Solid Waste Burial Grounds. A typical major burial ground that served a reactor area was a few hundred feet wide by several hundred feet long with burial trench depths

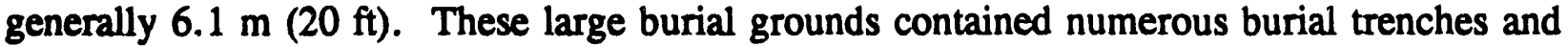
pits of various sizes and orientations depending on the material being buried. Pieces of equipment that had high dose rates (e.g., thermocouple stringers, horizontal control rods, etc.) were often placed into narrow but deep trenches and partially covered with earth fill. Small crib pits $2.4-$ by $2.4-\mathrm{m}$ (8- by 8 -ft) pits made from railroad ties) were often used for disposal of small reactor hardware having high dose rates. Vertical steel pipes/culverts (silos) 1.5 to $1.8 \mathrm{~m} \mathrm{(5} \mathrm{to} 6 \mathrm{ft}$ ) in diameter were also used for such wastes. Smaller burial grounds consisting of just one trench or pit were dug near the reactor buildings (Dorian and Richards 1978).

The 100-B/C Area burial grounds have been covered with a minimum of $1.2 \mathrm{~m} \mathrm{(4 \textrm {ft } )}$ of clean soil. The soil has been stabilized with gravel to prevent erosion by wind. In addition, burial grounds are treated with herbicides as needed to prevent radioactive migration by deep-rooted weeds. They are also routinely surveyed to ensure that contamination is not spreading to the environs (Dorian and Richards 1978).

2.1.3.9.1 118-B-1 Burial Ground. This site, also known as the 105-B burial ground or operations solid waste burial ground, is located about $914 \mathrm{~m}(3,000 \mathrm{ft})$ due west of the 105-C Reactor building. The site boundaries are permanently marked with concrete posts numbered B-81-1 through B-81-31. It runs in a north-south direction and is approximately 305 by $98 \mathrm{~m}$ (1,000 by $321 \mathrm{ft})$, with a depth of roughly $6.1 \mathrm{~m}(20 \mathrm{ft})$. The site consists of trenches (generally east-west direction), perforated burials (excavations shored with railroad ties), and spline silos.

The first trench in this burial ground was dug in 1944 and the site received waste until 1973. An estimated $10,000 \mathrm{~m}^{3}$ of waste have been buried at this site. The spline silos received metallic wastes (Stenner et al. 1988). The trenches received general reactor wastes from $100-\mathrm{B}$ and $100-\mathrm{N}$ reactors that included aluminum tubes, irradiated facilities, thermocouples, vertical and horizontal aluminum thimbles, stainless-steel gun barrels and expendables, plastic, wood, and cardboard (Dorian and Richards 1978).

In early 1950, another burial area was initiated south of and adjacent to the 118-B-1 burial trenches. This area was called the 108-B solid waste burial ground and is now considered part of the 118-B-1 burial ground. Solid ${ }^{3} \mathrm{H}$ wastes and high-level liquid ${ }^{3} \mathrm{H}$ wastes sealed in 8-mm (3-in.) diameter iron pipes were buried here. In 1952, this area was also used to dispose of contaminated tritium pots and irradiated process tubing. Another. trench contains contaminated perfs. Past documents discuss three trenches at this location covered with $1.8 \mathrm{~m}(6 \mathrm{ft})$ of soil (Heid 1956).

In the spring of 1956 , a small $61-$ by $15.2-\mathrm{m}(200-$ by $50-\mathrm{ft})$ extension was added adjacent to and at the middle of the west 118-B-1 boundary. Contaminated yokes from the 105-B Reactor building were buried in this extension (Heid 1956). 
An estimated radionuclide inventory is as follows (Stenner et al. 1988):

Constituent

$$
\begin{aligned}
& { }^{14} \mathrm{C} \\
& { }^{60} \mathrm{Co} \\
& { }_{137} \mathrm{Cs} \\
& { }^{152} \mathrm{Eu} \\
& { }^{154} \mathrm{Eu} \\
& { }^{3} \mathrm{H} \\
& { }^{63} \mathrm{Ni} \\
& { }^{90} \mathrm{Sr}
\end{aligned}
$$

Quantity in curies

(decayed through 4-1-86)

$$
\begin{array}{r}
0.66 \\
886.00 \\
1.50 \\
16.50 \\
30.20 \\
3,806.80 \\
96.60 \\
1.50
\end{array}
$$

Previous sampling of any of the 100 Area solid waste burial grounds was limited to the 118-B-1 burial ground, conducted in 1976 and reported by Dorian and Richards (1978).

Drilling was initiated on April 5, 1976 and completed on April 29, 1976. The locations of the sample holes and radionuclide concentrations are reported by Dorian and Richards (1978).

2.1.3.9.2 118-B-2 Burial Ground. This site was also referred to as construction burial ground no. 1 or minor construction burial ground no. 1. It is located about $137 \mathrm{~m}$ (450 ft) east of the 105-B Reactor building, directly west of the 118-B-3 burial ground. It runs in an east-west direction, is approximately 18.3 by $9.1 \mathrm{~m} \mathrm{(60} \mathrm{by} 30 \mathrm{ft}$ ), and is roughly $3.04 \mathrm{~m}$ ( $10 \mathrm{ft})$ deep. It consists of one trench running east and west containing dry waste from the 107-B basin repair work and from the 115-B alteration by minor construction. The site received waste from 1952 until 1956. An estimated volume of waste is $100 \mathrm{~m}^{3}$ and an estimated radionuclide inventory is $1.00 \mathrm{Ci}$ of ${ }^{60} \mathrm{Co}$ decayed through April 1, 1986 (Stenner et al. 1988).

2.1.3.9.3 118-B-3 Burial Ground. This site, also referred to as construction burial ground no. 2 or minor construction burial ground no. 2, is located about $200 \mathrm{~m}(650 \mathrm{ft})$ east of the 105-B Reactor building, directly east of the 118-B-2 burial ground. It runs east and west, is approximately 107 by $84 \mathrm{~m}$ ( 350 by $275 \mathrm{ft}$ ), and is roughly $6.1 \mathrm{~m}(20 \mathrm{ft}$ ) deep. It consists of many trenches also running east and west. The site received an estimated $5,000 \mathrm{~m}^{3}$ of solid waste from the effluent line modification and reactor-generated solid waste during various modification programs between 1956 and 1960. An estimated radionuclide inventory is $1.00 \mathrm{Ci}$ of ${ }^{60} \mathrm{Co}$ decayed through April 1, 1986 (Stenner et al. 1988).

2.1.3.9.4 118-B-4 Burial Ground. This site was also called the 105-B spacer burial ground or the 105-B dummy burial ground. It is located within the 105-B exclusion area fence about $91.4 \mathrm{~m}$ (300 ft) northeast of the $105-5$ Reactor building. Burial grounds located inside reactor exclusion area fences were not required to be permanently marked with concrete marker posts. It is approximately 15.2 by $9.2 \mathrm{~m} \mathrm{(50} \mathrm{by} 30 \mathrm{ft}$ ) and roughly $4.6 \mathrm{~m}$ (15 ft) deep. It consists of six pits containing 1.8-m (6-ft) diameter metal culverts buried vertically. The site was used between 1956 and 1958 for disposal of fuel spacers. 
An estimated volume of waste is $70 \mathrm{~m}^{3}$ and an estimated radionuclide inventory is $1 \mathrm{Ci}$ of ${ }^{60}$ Co decayed through April 1, 1986 (Stenner et al. 1988).

2.1.3.9.5 118-B-6 B Burial Ground. This site was known in past documents as the 108-B solid waste burial ground no. 2. It is located about $107 \mathrm{~m}$ (350 ft) northeast of the 105-B Reactor building, just outside the 105-B exclusion area fence. It is approximately

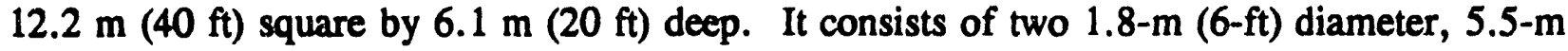
(18-ft) long concrete pipes buried vertically. Light metal caps have been placed over the pipes. Tritium wastes and ${ }^{3} \mathrm{H}$ recovery process wastes, primarily aluminum target cans and lead target melting pots were buried here. An estimated volume of waste is $10 \mathrm{~m}^{3}$ and an estimated radionuclide inventory is $1,000 \mathrm{Ci}$ of ${ }^{3} \mathrm{H}$ decayed through April 1, 1986 (Stenner et al. 1988).

2.1.3.9.6 118-C-1 Burial Ground. This site was also known as the 105-C burial ground or the 105-C solid waste burial ground. It runs in an east-west direction, is approximately 155.4 by $122 \mathrm{~m}$ (510 by $400 \mathrm{ft}$ ) (trapezoid), and is roughly $4.6 \mathrm{~m}(15 \mathrm{ft}$ ) deep. It is located about $152.4 \mathrm{~m}(500 \mathrm{ft})$ southeast of the $105-\mathrm{C}$ Reactor building. The site boundaries are permanently marked with concrete marker posts numbered C-70-1 through C-70-21. It consists of many trenches running north and south, and six, 3.04 by 3.04 by $4.6 \mathrm{~m}$ ( 10 by 10 by $15 \mathrm{ft}$ ) deep pits. The site received miscellaneous solid wastes from the 105-C building including pressure tubes, aluminum spacers, control rods, soft wastes, and reactor hardware. It was in service from the spring of 1953 until 1969. An estimated waste volume is $10,000 \mathrm{~m}^{3}$ and an estimated radionuclide inventory is as follows (Stanner et al. 1988):

Constituent<smiles>[CH]1[CH]CC1</smiles>

${ }^{60} \mathrm{Co}$

${ }^{137} \mathrm{Cs}$

${ }^{152} \mathrm{Eu}$

${ }^{154} \mathrm{Eu}$

${ }^{3} \mathrm{H}$

${ }^{63} \mathrm{Ni}$

${ }^{90} \mathrm{Sr}$
Quantity in curies

(decayed through 4-1-86)

3.64

571.00

1.30

14.20

26.00

8.50

62.60

1.30

2.1.3.10 Burning Pits. Burning pits were used to incinerate nonradioactive combustible material, mostly trash, office waste, and small amounts of solvents and paint wastes.

The four burn pits in the $100-\mathrm{B} / \mathrm{C}$ Area, only one, $128-\mathrm{C}-1$, is in the $100-\mathrm{BC}-2$ operable unit. This site may have been called the 100-C burning pit. It is located due east of the 105-C Reactor building between the protected area fence and the 105-C Area perimeter road. It is approximately 68.6 by $38.1 \mathrm{~m}$ (225 by $125 \mathrm{ft}$ ) with broken glass and ash marking the area. Some smaller areas show signs of surface burning and dumping. The waste consisted of combustible material (vegetation, office wastes, paint waste, chemical 
solvents), hardware, and noncontaminated miscellaneous equipment (DOE-RL 1992c). Actual service dates are not known, however, the area is no longer in use. No waste inventories exist for this facility nor has any sampling been conducted.

2.1.3.11 Unplanned Releases. Regular surface radiation monitoring is performed in the 100-B/C Area that is intended, in part, to detect new releases from known waste disposal sites. Surface monitoring of radiologically controlled areas (e.g., cribs, burial grounds, contaminated sites) is performed at least annually. More frequent radiation surveys may be done, depending on the extent of contamination present and the history of each site. In general, mobile sodium iodide detectors are used for monitoring. Depending on the particular site characteristics, other monitoring methods such as beta-sensitive detectors or hand-held survey instruments may be employed. Historical research is ongoing that may identify unplanned releases not previously documented.

\subsubsection{Waste-Generating Processes}

Radioactive and nonradioactive wastes were produced during uperation of the C Reactor and its support facilities. These wastes contributed to the present-day contamination in the 100-BC-2 operable unit.

2.1.4.1 Reactor Process Liquid Wastes and Cooling Water Effluent. The liquid effluents generated as a direct result of 100-B/C Area reactor operations consisted primarily of reactor cooling water effluent, fuel storage basin water, and decontamination solutions. These effluents, along with liquid waste from the ${ }^{3} \mathrm{H}$ recovery facility in the $100-\mathrm{BC}-1$ operable unit, are thought to be the most significant wastes in the 100-B/C Area in terms of potential impact on the groundwater. Tens of millions of gallons of this waste were disposed of directly to the soil column in the 100-B/C Area, both intentionally and as a result of leaks in the cooling water effluent system. The processes that generated these effluents are discussed below. Figure 2-4 is a schematic of the reactor cooling water and process sewer pipelines.

2.1.4.1.1 Reactor Cooling Water System. A continuous supply of high quality cooling water was essential to reactor operations to prevent damage to the reactor core from excess heat generated by the fission reactions. Many of the facilities in the 100-B/C Area were part of this cooling water system. At a daily use rate of 189 to 379 million L (50 to 100 million gal) of cooling water per reactor, this system generated the largest waste volume in the area.

Water obtained from the Columbia River was treated and then circulated in a single pass through the reactor fuel process tubes, cooling tubes imbedded in the thermal shield, and reactor horizontal control rods. The cooling water exiting the reactor contained radioactive species from the reactor and chemical contaminants added to treat the raw water before use. After exiting the reactor, the cooling water passed through a retention basin system and then was discharged to the Columbia River.

Water from the Columbia River was pumped from the 181-C river pumphouse in the northwest corner of the $100-\mathrm{BC}-1$ operable unit to the $183-\mathrm{C}$ water treatment facility in the 
100-BC-2 operable unit. At the 183-C facility, the river water was treated with chemical additives. These additives consisted of alum with excess sulfuric acid (to enhance the removal of suspended sediment by flocculation), hydrated calcium oxide (to control water $\mathrm{pH}$ ), and chlorine (to control algae growth in the settling basins). The $\mathrm{pH}$ was maintained at about 7.5, and the free chlorine residual was approximately $0.2 \mathrm{mg} / \mathrm{L}$ (Richards 1953). The alum was produced in the upper floor of the head house of the 183-C water treatment building by mixing bauxite with sulfuric acid. The bauxite was stored in bunkers in the third floor while the concentrated sulfuric acid was stored in steel tanks outside of the building (General Electric 1963). The additives were introduced as the water passed down a flume into a mixing chamber. From there, the water was transferred to a basin equipped with paddle wheel flocculators.

After passing through the flocculators, the water passed to one of eight open-air settling basins, also located within the $183-\mathrm{C}$ facility, where the heavier particulate matter was allowed to settle out. Finally, an organic polyelectrolyte was added and the water was filtered through beds of gravel, sand, and crushed anthracite coal. The filters were backwashed periodically, and wastewater from the filters was discharged into an unspecified sewer (General Electric 1963), presumably the process sewer with an outlet to the Columbia River at the 132-C-2 outfall structure. Locations of disposal sites used for any sludges produced from this process are currently unknown.

Water exiting from the filters was piped to two 11-million-L (3-million-gal) clearwells in the 183-C building for temporary storage and then to large-capacity storage tanks (four tanks at 20 million L [5.25 million gal] each) located west of the 190-C building. Approximately $2 \mathrm{mg} / \mathrm{L}$ sodium dichromate was added at the inlet of these tanks to inhibit corrosion (Richards 1953). Water was also pumped from the 183-C clearwells to two elevated emergency itorage tanks (1 million L [300,000 gal] each) north and south of the C Reactor. To identify areas of potential toxic substance leakage, detailed schematics of the water treatment facilities are needed and considered a data gap.

The water stored in the four storage tanks located between the 183-C and 190-C buildings was passed to a high-pressure pumping station located in the 190-C building. From there, the water was piped to a valve pit in the $C$ Reactor building, then pumped to the reactor. The water entering the reactor contained variable amounts of alum, sulfuric acid, chlorine, calcium, sodium dichromate, organic polyelectrolytes, and residual impurities naturally present in the Columbia River water that were not removed during treatment.

There were several flow paths through the reactor block itself. The primary cooling water pathway was through the process tubes in which the cylindrical fuel elements were located. The design of the fuel elements permitted cooling waier to flow through the center of the element as well as around the outside. Cooling water also flowed through cooling pipes located in the thermal shield, and the horizontal control rods and experimental test holes that penetrated the reactor core. The cooling water streams from all flow pathways were recombined before leaving the reactor. A diatomaceous earth slurry, used regularly to scour the corrosion film from the piping and tubes in the reactor, was also introduced to the cooling water effluent. This slurry was a major source of solids in the cooling water. 
The cooling water was at near-boiling temperature when it left the reactor block. The water was passed to riser pipes on each side of the rear of the reactor, then to a crossover pipe located above the reactor, and finally to a downcomer. The water entering the downcomer cascaded downward over metal baffles, resulting in some cooling. Vapors were vented through the top of the downcomer to the reactor building ventilation exhaust system. This was a source of radioactive contamination to the ventilation system. Water in the downcomer was gravity-fed to the cooling water effluent system.

The total volume of cooling water exiting the $\mathbf{C}$ Reactor during normal operations was originally about $246,000 \mathrm{~L} / \mathrm{min}(65,000 \mathrm{gal} / \mathrm{min})$. In 1960 , higher-capacity pumps were installed that increased this flow by approximately $34,065 \mathrm{~L} / \mathrm{min}(9,000 \mathrm{gal} / \mathrm{min}$ ) (DeNeal 1965).

While the water was in the reactor, it absorbed thermal energy from the nuclear process and became contaminated with radioactive isotopes. There were several sources of contamination:

- The high neutron flux in the reactor activated elements in the cooling water, creating species such as calcium-41 $\left({ }^{41} \mathrm{Ca}\right)$, chromium-51 $\left({ }^{51} \mathrm{Cr}\right)$ and zinc-65 $\left({ }^{65} \mathrm{Zn}\right)$. Most of those species were relatively short-lived and have since decayed to negligible levels.

- Activation products from the graphite stack, other reactor components and fuel cladding were introduced into the cooling water. Significant species included ${ }^{3} \mathrm{H},{ }^{14} \mathrm{C}$, ${ }^{60} \mathrm{Co},{ }^{63} \mathrm{Ni}$, and ${ }^{152,154,155} \mathrm{Eu}$.

- Fuel element fission products, such as ${ }^{90} \mathrm{Sr}$ and ${ }^{137} \mathrm{Cs}$, and transuranics, such as ${ }^{239 / 240} \mathrm{Pu}$ were introduced into the cooling water in the event of a fuel-cladding failure.

The water was transferred from the $C$ Reactor building through the process effluent lines to the 116-C-5 retention basin in the 100-BC-1 operable unit for thermal cooling and decay of short-lived radionuclides. The retention time in the 116-C-5 retention basin was approximately $2.8 \mathrm{~h}$ (Soldat and Quimby 1953). The 116-C-5 retention basin was used from 1952 until 1969.

From the retention basin, the water was transferred through the 132-C-2 outfall structure to pipes that discharged at the bottom center of the Columbia River. Overflow from the 100-B/C Area retention basins could also discharge directly to the shore of the river through spillways located near the outfall structures. There is substantial evidence that the retention basins and effluent lines leaked, releasing cooling water to the area in and around the basins, lines, and shore at a rate as high as several thousand gpm (Dorian and Richards 1978).

During reactor operation, ruptures of the fuel element cladding frequently occurred while the fuel elements were in the process tubes. When failures occurred, contamination levels increased in the bulk cooling water exiting the reactor, and the cooling water in the 
affected process tube became highly contaminated. Between 1948 and 1963, there were 346 reported fuel cladding failures (Koop 1964).

Two systems were devised to prevent both the bulk effluent and the water from the affected process tube from being discharged directly to the Columbia River during fuel cladding failures. Both systems involved discharging the liquid to soil column waste disposal units.

- The 116-C-5 retention basin was constructed with two tank compartments that were filled sequentially. This allowed cooling water to be diverted and segregated in the second empty compartment if elevated contamination levels were indicated by the monitoring equipment. The segregated cooling water was then transferred to the 116-C-1 trench excavated east of the basin. The 116-C-1 trench and the 116-C-5 basin are located within the 100-BC-1 operable unit boundary.

- Soil column disposal sites called "pluto cribs" were constructed east of the B and $\mathrm{C}$ reactors. The purpose of the $116-\mathrm{C}-2 \mathrm{~A}$ crib that served the $\mathrm{C}$ reactor was to receive the highly contaminated water that was flushed directly from the process tube affected by the fuel cladding failure (see Section 2.1.3.1.2).

2.1.4.1.2 Fuel Storage Basin Water. The fuel storage basin in the C Reactor building was used to collect, store, and transport irradiated fuel elements discharged from the reactor. In the $6.1-\mathrm{m}(20-\mathrm{ft})$ deep basin, the fuel elements were kept under a water shield $4.9 \mathrm{~m}(16 \mathrm{ft})$ deep.

Between December 1984 and October 1985, the C Reactor fuel storage basin was cleaned out and stabilized (Miller 1987). Miscellaneous debris, including equipment and hardware in the basin, was removed, packaged, and disposed of as appropriate. The C Reactor fuel storage basin facility served as a temporary storage area for suspect fuel elements removed from other reactors. Suspect fuel elements were subsequently transferred to the N Reactor for identification (Miller 1987). Approximately $17 \mathrm{~m}^{3}\left(600 \mathrm{ft}^{3}\right)$ of sludge and sediment totalling about $50,000 \mathrm{~kg}$ (55 tons) were transferred from the storage basin and consolidated in the fuel transfer pit located adjacent to the storage basin in the C Reactor building (Miller 1987). The transfer pit was then shielded with a cap and the walls above the sludge were coated with an asphalt emulsion (Miller and Steffes 1987).

Approximately $2,157,450 \mathrm{~L}(569,938 \mathrm{gal})$ of basin shielding water was removed separately (Miller and Steffes 1987). The storage basin was then washed with a highpressure water jet and the walls and floor were coated with an asphalt emulsion. The washwater was combined with the shielding water and processed through a filtration system and treatment system that removed entrained sediment and radiological contaminants from the water. It is not stated where these residues were disposed. The treated water was analyzed to verify that it met ARCL release criteria, then discharged to the unlined 116-C-6 pond east of the C Reactor building (Dement 1988) (see Figure 2-1). 
2.1.4.1.3 Decontamination Solutions. During both reactor operations and reactor shutdowns, large quantities of decontamination solutions were routinely used to remove radionuclides from facility equipment and facility surfaces. Decontamination activities took place at the $\mathrm{C}$ Reactor dummy decontamination facility inside the reactor building.

Known decontamination solutions included chromic, citric, oxalic, nitric, sulfamic and sulfuric acids (neutralized with sodium carbonate before disposal), and sodium fluoride. Other chemicals, including organic solvents, were used for some decontamination processes. These spent decontamination solutions were generally discharged to cribs, trenches, or french drains (open-bottom drairiage holes filled with loose stone) in the immediate vicinity of the building where they were used. At the $\mathrm{C}$ Reactor, three disposal options were available, the process sewer, cooling warer (process effluent), or disposal to the 116-C-2 pluto crib system. Two disposal paths accessible by the reactor itself were the pluto crib and the process effluent lines. The spent decontamination solutions from the $\mathrm{C}$ Reactor most likely went to the 116-C-2A crib. The solutions contained both radionuclide and chemical contaminants. Some of the compounds used in the decontamination solutions, such as organic complexants like oxalate, may have solubilized and transported radionuclides and metals.

2.1.4.2 Radioactive Sludge/Solid Wastes. Several thousand tons of radioactive sludge were generated during reactor operations, and ascumulated in pipes in the cooling water effluent system and in the reactor fuel storage basin (Dorian and Richards 1978). Smaller volumes of sludge also collected in water traps located in the 132-C-3 air filter building. The sludge consisted of the diatomaceous earth used periodically to scour the reactor process tubes and fine particulate matter that originated from dissolved and suspended solids in the river water, pipe slag, dust, failed fuel elenients, graphite powder, and other undefined solids.

The bulk of the sludge in the 100-BC-2 operable unit accumulated in the $\mathrm{C}$ Reactor fuel storage basin and the 116-C-2A pluto crib system. As discussed in Section 2.1.4.1.2, the fuel storage basin sludge was consolidated into the fuel transfer pit in the reactor building between 1.984 and 1985 .

Radioactive solid wastes generated in the 100-BC-2 operable unit generally consisted of reactor components, contaminated equipment and tools, and miscellaneous contaminated items (paper, rags, structural concrete, etc.). The main source of these wastes was reactor operations in the $\mathrm{C}$ keactor building, and the most highly contaminated solid wastes were the reactor components. The Ball 3X system was used for emergency r tactor control (General Electric 1963). Miller and Wahlen (1987) estimate that $9,070 \mathrm{~kg}$ (10 tons) of $9.5-\mathrm{mm}$ (0.375-in.) diameter solid nickel-plated boron steel and carbon steel balls used for this emergency system are still contained in the 118-C-2 Ball 3X storage tank within the 100-BC-2 operable unit.

Neutron activation of elements in the reactor components caused them to become radioactive. In addition, both the reactor components and other solid objects received surface contamination from contact with radioactive solutions and environments. The predominant radionuclides associated with the reactor components are ${ }^{60} \mathrm{Co}$ and ${ }^{63} \mathrm{Ni}$ (Dorian and Richards 1978). Some unknown miscellaneous reactor components are suspected to be 
contained within the 118-C-4 horizontal control rod storage cave south of the C Reactor building (DOE-RL 1992c). Graphite is also a reactor waste that was disposed of in the solid waste burial grounds. Graphite dust as well as ${ }^{14} \mathrm{C}$ are considered contaminants associated with solid waste burial grounds.

It is likely that other facilities associated with the $\mathrm{C}$ Reactor and waste management activities also generated radioactive solid wastes. Examples are air filters in the 132-C-3 exhaust air filter building, equipment used in connection with the cooling water effluent system, and contaminated dirt removed from near the effluent lines. The primary burial ground for the C Reactor was the 118-C-1 burial ground.

Radioactive solid waste currently included within the boundaries of the 100-BC-2 operable unit exists as buried building foundations, the demolished exhaust air stack, underground contaminated concrete-lined tunnels, buried pieces of concrete and other materials from demolished buildings, solid waste burial grounds, and underground pipelines. In cases where decontamination and decommissioning have occurred, radiation levels are low. Contamination in these cases results mainly from surface contact with contaminated air, dust, and liquid solutions.

2.1.4.3 Reactor Ventilation System and Inert Gas System Wastes. There were two gas systems associated with the C Reactor, the primary ventilation system and the inert gas system. Prior to 1960 , the primary ventilation system released air directly from the reactor building to the 132-C-1 stack and subsequently to the atmosphere. The air in the reactor building became contaminated with radionuclides that were present as radioactive gases and entrained vapors and particulates generated ; the cascade of cooling water in the reactor. The emissions may have resulted in surface contamination in the $100-\mathrm{B} / \mathrm{C}$ Area.

In approximately 1960, a filtering system was added to minimize the release of radioactive matter from the reactor building (General Electric 1963). This filtering system was placed below ground in the 132-C-3 building just south of the $\mathrm{C}$ Reactor. The exhaust air was passed downward through a duct to a tunnel leading to the filter building. After filtration, the air was routed back through a second tunnel to the air exhaust stack. Two types of filter banks wera used: a fine particulate removal bank and an activated charcoal bank. Samples obtained during decommissioning of the 132-C-3 building revealed that the inside surfaces of the concrete-lined tunnels, and the equipment and wall surfaces of the fan rooms and filter chambers in the $132-\mathrm{C}-3$ building had surface radioactive contamination (Dorian and Richards 1978).

The purpose of the reactor inert gas system was to provide a closed-loop nonreactive gas environment in the graphite core that would remove moisture and gases from the core, serve as a heat transfer medium between the graphite core and the process tubes, and detect water leaks within the reactor core. The B and C Reactors shared an inert gas system located in the 132-B-5 gas recirculation building within the $100-\mathrm{BC}-1$ operable unit. A mixture of helium and carbon dioxide, driven at low pressure by a blower system located in the 132-B-5 facility, was circulated through the graphite pile. Filters, gas coolers, blowers, condensers and silica gel drying towers were located within the 132-B-5 building. The system was designed to maintain gas pressure in the reactor at a slight positive value, which 
assured circulation and avoided in-leakage of air. When excessive pressure or in-leakage of air was detected, the gas was routed to the ventilation exhaust system. Contamination of the 132-B-5 building occurred on the inside surfaces of ducts, concrete surfaces, machinery, and filters, as indicated by analysis of smear samples taken from these surfaces (Dorian and Richards 1978). The 132-B-5 building was connected by tunnels to the B Reactor building and by underground piping tunnels to the $C$ Reactor building; both the tunnel and the piping are also radioactively contaminated (Dorian and Richards 1978).

2.1.4.4 Sanitary Liquid Wastes. Sanitary wastes were produced in the various buildings equipped with sanitary facilities in the 100-BC-2 operable unit (see Section 2.1.3.5). These wastes were routed by sewer lines to four septic tanks and associated leach fields located within the 100-BC-2 operable unit. Nonsanitary wastes such as detergents, cleaning compounds and solvents likely entered these sewer systems. There are no records of radiological wastes being disposed of to these sewer systems.

2.1.4.5 Nonradioactive Liquid Wastes. Nonsanitary, nonradioactive liquid chemicals that were used at the $100-\mathrm{B} / \mathrm{C}$ Area potentially contributed to contamination in the $100-\mathrm{BC}-2$ operable unit. These include hazardous wastes and hazardous substances. Contamination from liquids, including gasoline, diesel fuel, solvents, and other chemical compounds, would be expected near aboveground or belowground storage tanks and their piping systems and in areas where these materials were used or stored. Releases could have resulted from leakage, spillage, or disposal at unknown locations, or discharge into the process sewer. Identification of organic solvents used onsite is considered a data gap. The following activities may have resulted in the generation of nonradioactive liquid wastes:

- Water treatment chemicals (alum, sulfuric acid, chlorine, sodium dichromate) were used and stored near the 183-C and 190-C buildings, as discussed previously.

- Wet-type electrical transformers and hydraulic machinery containing oil contaminated with PCB may have been used at several locations within the 100-BC-2 operable unit. Fluids contaminated with PCB may have been released or disposed of during operation, equipment repair, or decommissioning and demolition activities.

- Emergency electrical power for instrumentation in the C Reactor building consisted of two backup systems, a 10-kVA gasoline engine generator for the station in general and a set of batteries for the Ball $3 X$ system. The storage tank location for the gasoline engine is not known.

2.1.4.6 Nonradioactive Solid Wastes. Nonradioactive solid waste generated in the 100-B/C Area primarily included miscellaneous materials such as paper, trash, pieces of metal, plastic parts, etc., generated in the facilities, as well as sludges that were a product of the water treatment process. 
Other solid waste consisted of concrete, metal parts, and other materials generated during decommissioning and demolition activities. Asbestos, chemical waste, and contaminated solids were removed from the area during the decontamination and decommissioning work. Building materials that were not considered to be contaminated were buried in place or carried to the $100-\mathrm{BC}-1$ operable unit coal storage yard and buried.

\subsubsection{Interactions with Other Operable Units}

As shown in Figure 1-2, the 100-BC-2 operable unit is bordered on the north by the 100-BC-1 operable uni:; the 100-BC-5 operable unit (the groundwater unit) underlies the entire 100-B/C Area. The RI/FS activities for the 100-BC-1 and 100-BC-5 operable units were initiated in 1992. Information gained from RI/FS work at the 100-BC-1 and 100-BC-5 operable units will be used as much as possible to guide activities at the 100-BC-2 operable unit.

The RI/FS activities to be performed at other operable units in the Hanford Site 100 Area will also be integrated with the work at the $100-\mathrm{BC}-2$ operable unit. Other operable units for which work plans have been approved and work is under way are 100-HR-1, 100-HR-3, 100-DR-1, 100-KR-1, 100-KR-4, 100-NR-1, 100-NR-2, 100-FR-1, and 100-FR-3. Information gathered at one operable unit will be evaluated for relevance by investigators at other operable units and used where appropriate. The analogous facility approach is employed when evaluating waste sites before an IRM is considered. Relevant data are evaluated as part of the scoping process, descriptions of work, and LFI reports.

\subsubsection{RCRA Considerations}

According to Appendix B of the Action Plan (Attachment 2) of the Tri-Party Agreement, there are no Resource Conservation and Recovery Act of 1976 (RCRA) treatment, storage, or disposal (TSD) facilities located at the 100-B/C Area (Ecology et al. 1990a). Also, according to Appendix C of the Action Plan, none of the listed past-practice waste disposal units at the $100-\mathrm{B} / \mathrm{C}$ Area have been assigned corrective action authority under RCRA; they are all designated as CERCLA past-practice units.

\subsection{PHYSICAL SETTING}

This section describes the physical setting of the 100-BC-2 operable unit, including topography, geology, geohydrology, surface-water hydrology, meteorology, environmental resources, and human resources. Because of the generic nature of the physical setting information Section 2.2 of the 100-BC-1 work plan (DOE-RL 1992a) can be referenced for discussion of:

Section 2.2.1 - Topography

Section 2.2.2 - Regional Geology

Section 2.2.3 - Geohydrology 
Section 2.2.4 - Surface Water Hydrology

Section 2.2.5 - Meteorology

Section 2.2.6 - Environmental Resources

Section 2.2.7 - Human Resources.

The groundwater beneath the $100-\mathrm{BC}-2$ operable unit is included in the $100-\mathrm{BC}-5$ groundwater operable unit, and is described in more detail in that work plan (DOE-RL 1992b). Meteorological data have been collected at the Hanford Meteorological Station (HMS) since 1945; before that time, precipitation and temperature data are available from several nearby locations. Stone et al. (1983) and the Final Environmental Impact Statement for Disposal of High-Level Transuranic, and Tank Wastes (DOE 1987) summaize much of the available meteorological data.

One aspect of the physical setting where $100-\mathrm{BC}-2$ and $100-\mathrm{BC}-1$ differ is in the flooding potential. The elevation of the $100-\mathrm{BC}-2$ operable unit is such that the damregulated maximum flood height would not be expected to inundate the operable unit.

The geology of the $100 \mathrm{~B} / \mathrm{C}$ Area is presented in Figure 2-9. The local geology of the $100-\mathrm{BC}-2$ operable unit is presented in Figures 2-10 through 2-13. Figure 2-10 is a map of the monitoring wells in the $100 \mathrm{~B} / \mathrm{C}$ Area. Figures 2-11 through 2-13 are the geologic logs of the monitoring wells drilled in the $100-\mathrm{BC}-2$ operable unit. Figure 2-14 is the wind patterns at different locations on the Hanford Site. 
DOE/RL-91-07, Rev. 0

Figure 2-1. Map of 100-BC-2 Operable Unit.

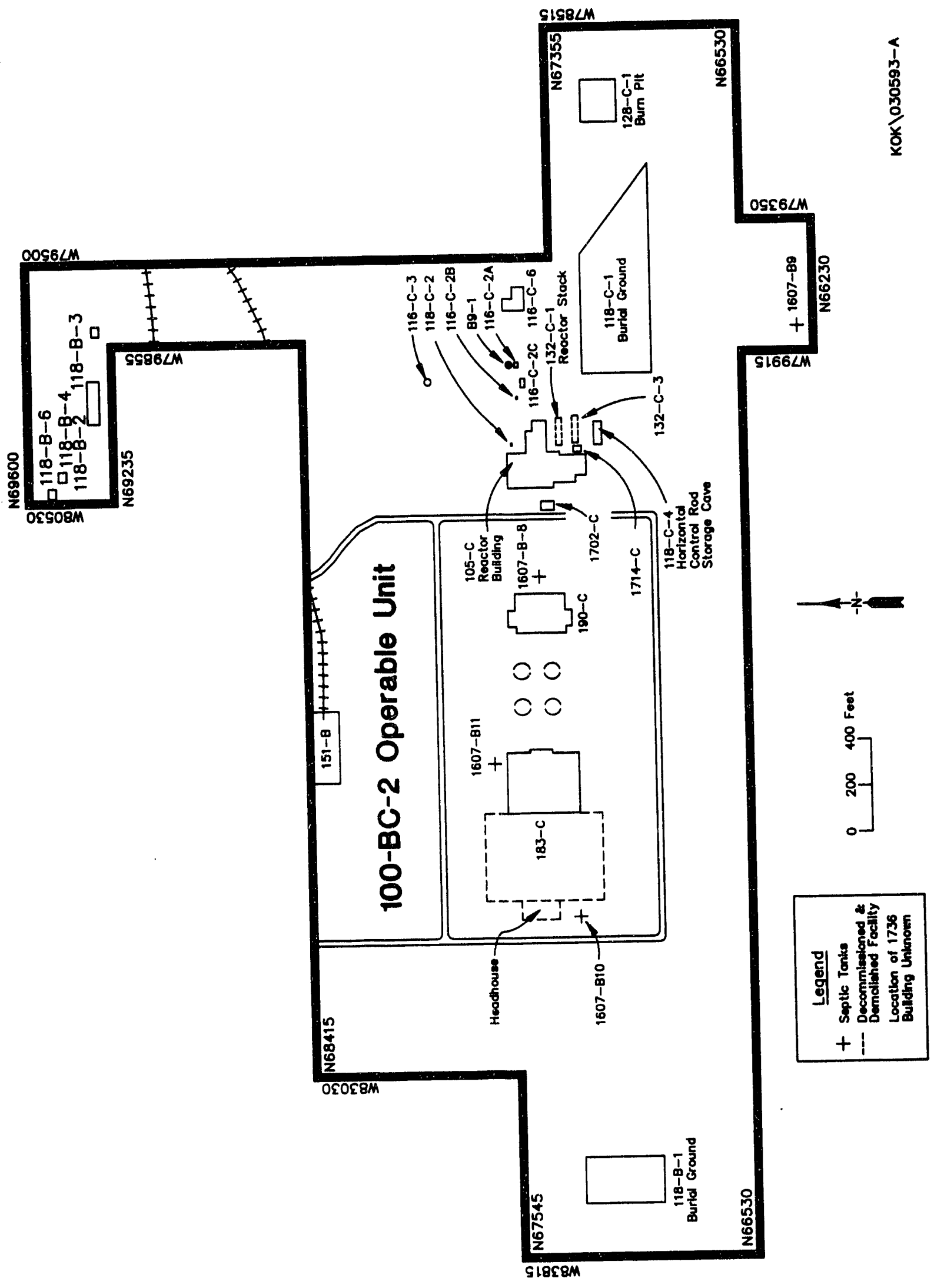


DOE/RL-91-07, Rev. 0

Figure 2-2. Top View of 116-C-2 Pluto Crib System.

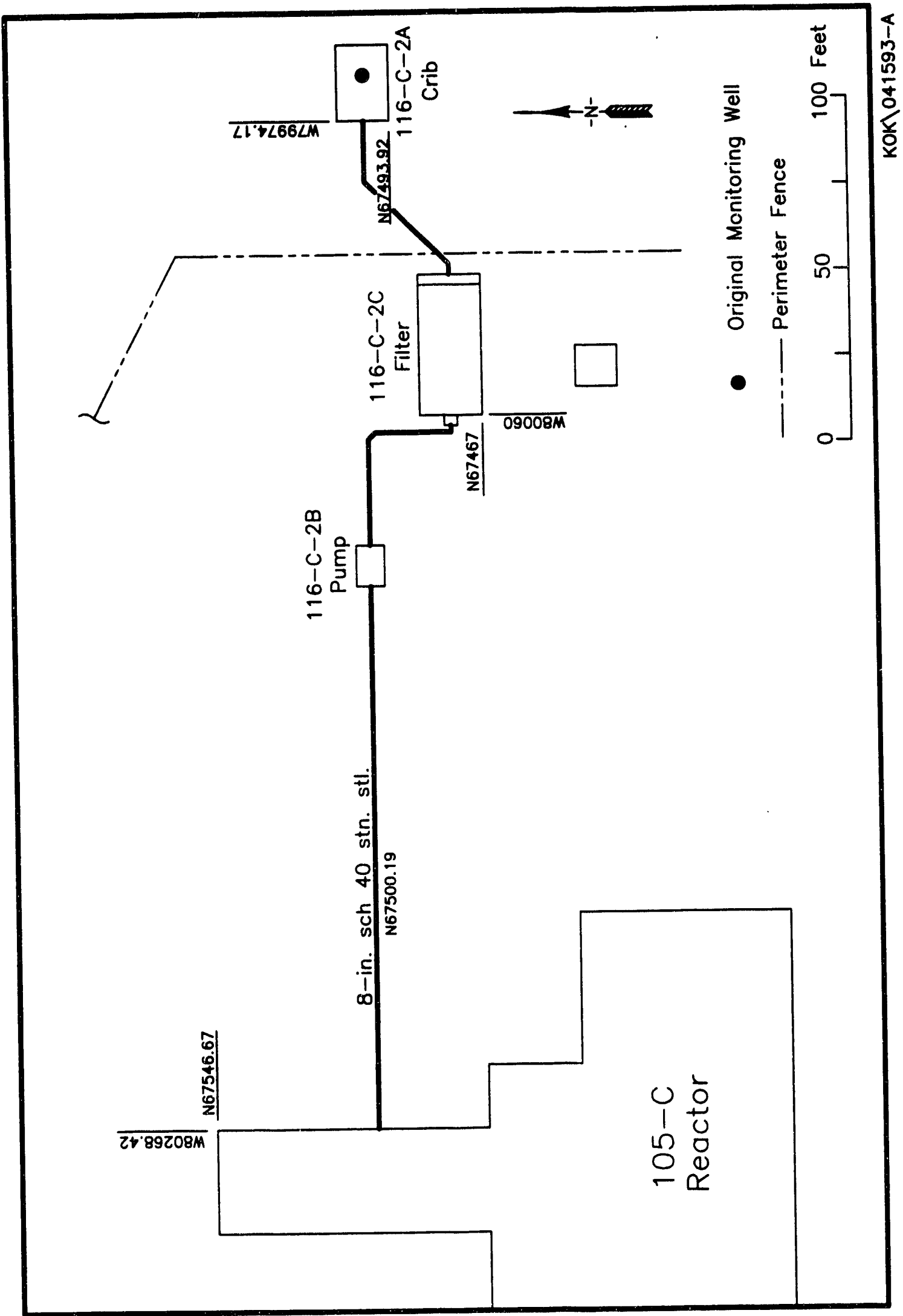

WP 2F-2 
DOE/RL-91-07, Rev. 0

Figure 2-3. Side View of 116-C-2 Pluto Crib System.

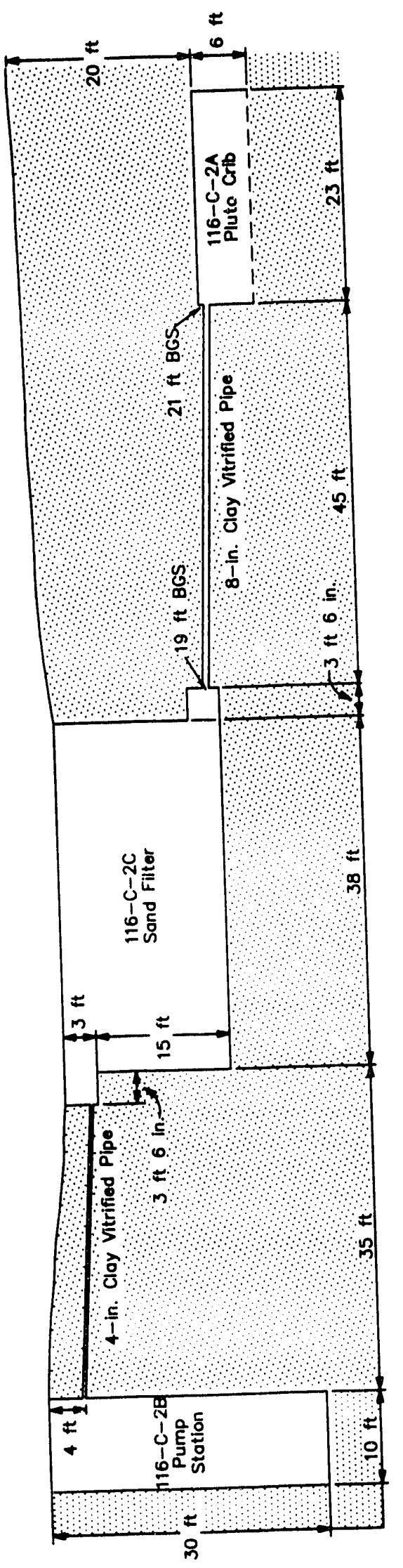

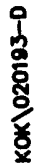


DOE/RL-91-07, Rev. 0

Figure 2-4. Schematic of 116-C-2A Pluto Crib.
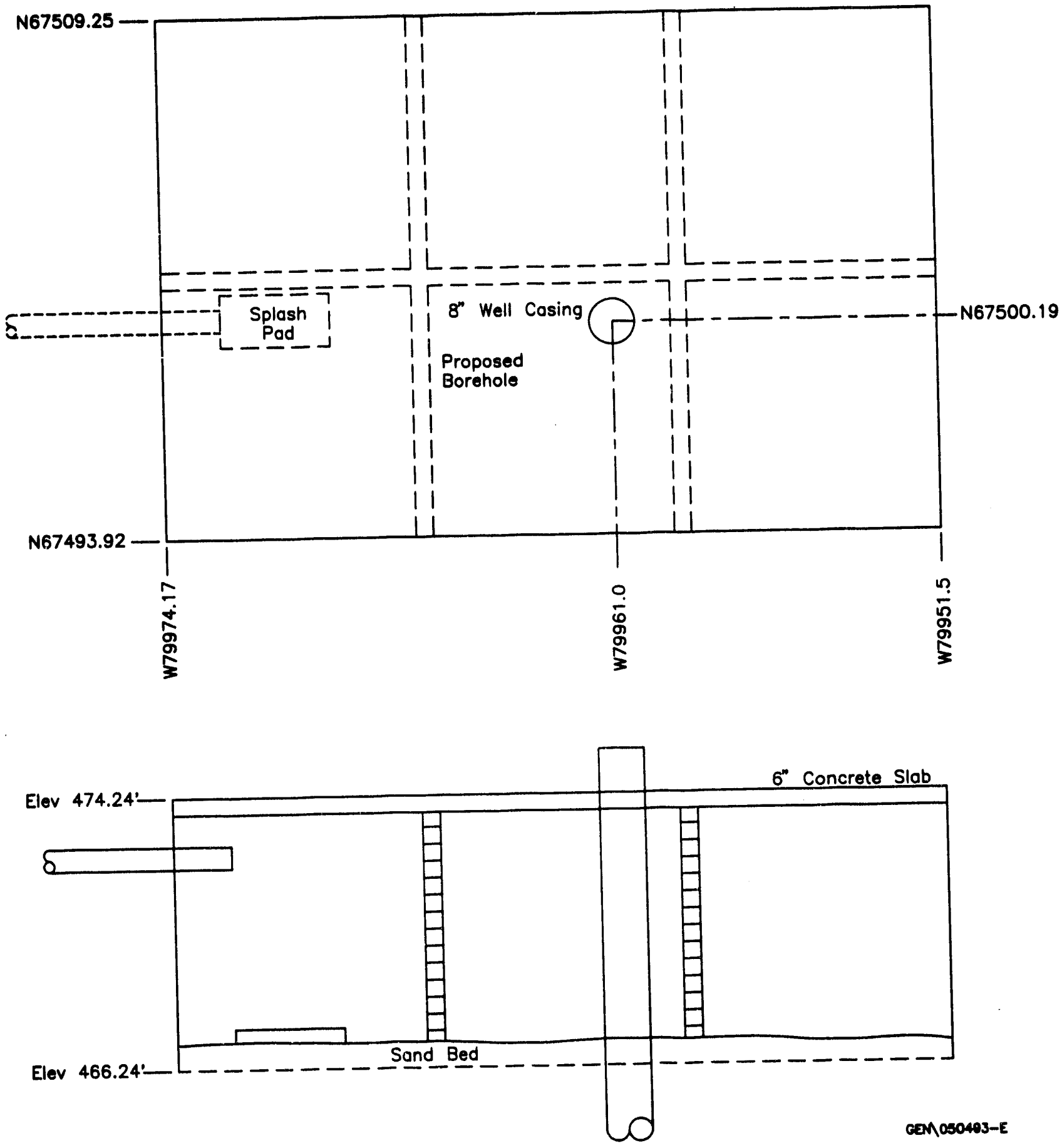
DOE/RL-91-07, Rev. 0

Figure 2-5. Schematic of 116-C-2B Pump Station.

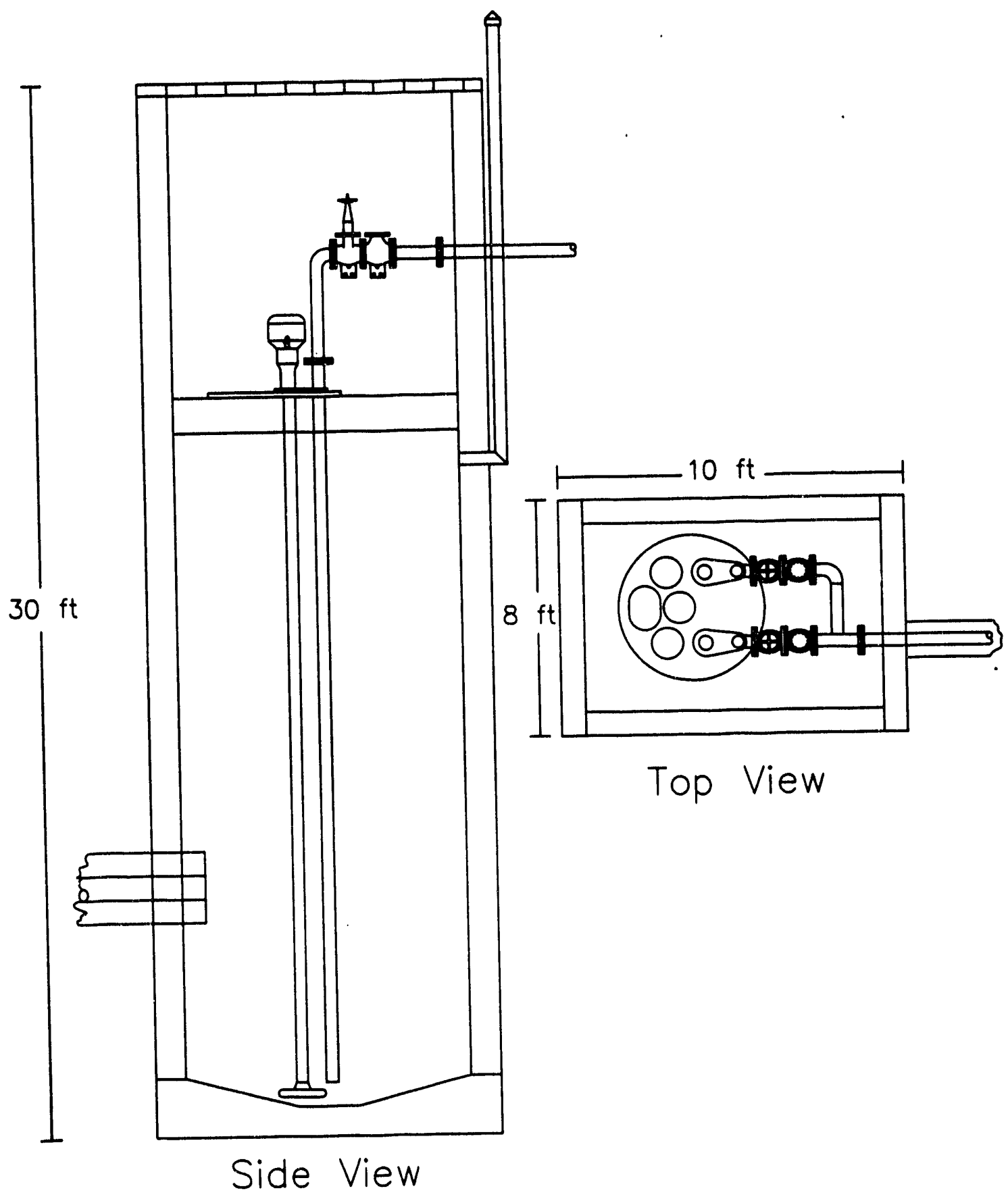

KOK $\backslash 050503-A$ 
DOE/RL-91-07, Rev. 0

Figure 2-6. Schematic of 116-C-2C Sand Filter.
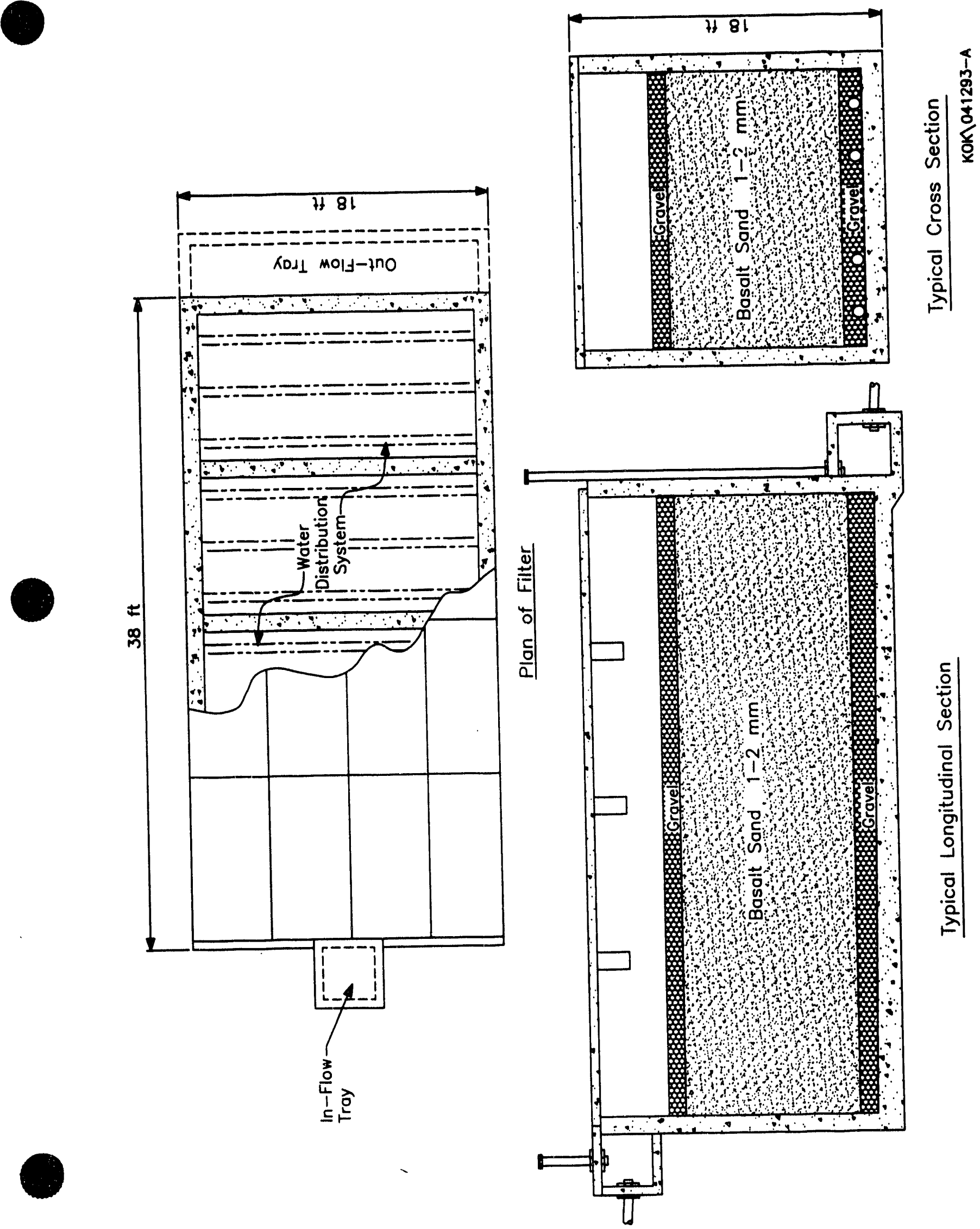

WP 2F-6 
Figure 2-7. Sampling Locations at 116-C-2 Pluto Crib Systems.

(Dorian and Richards 1976)
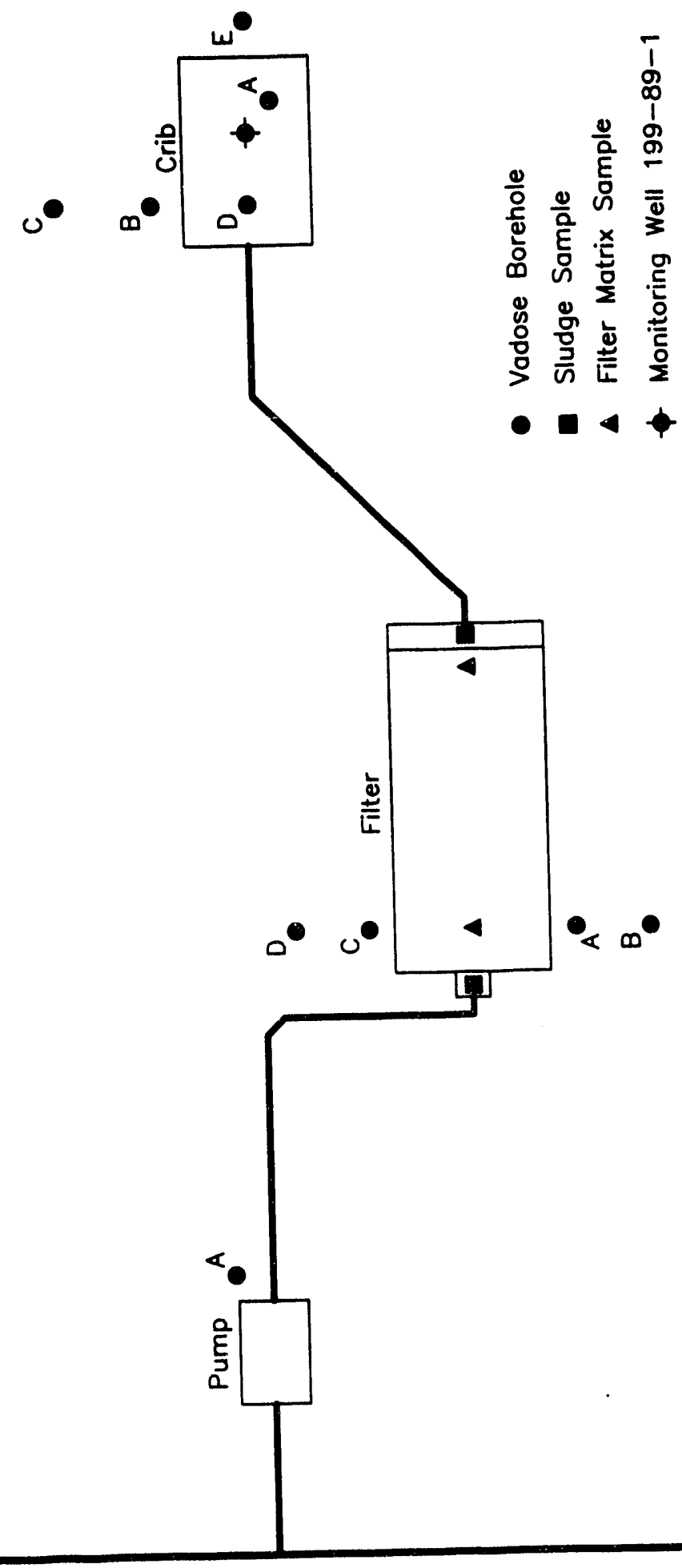
DOE/RL-91-07, Rev. 0

Figure 2-8. Piping Schematic: Process Sewer and Cooling Water.

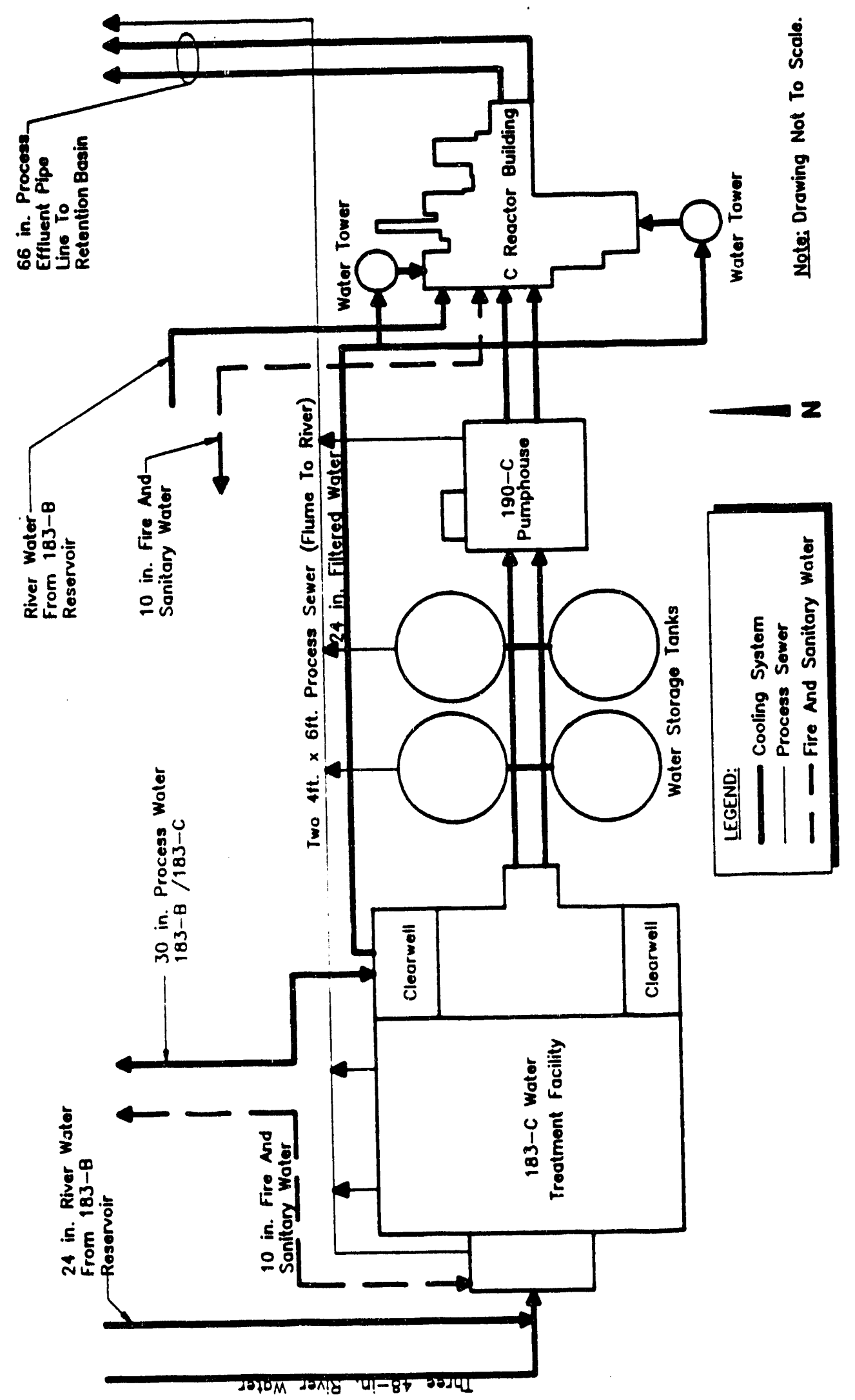


DOE/RL-91-07, Rev. 0

Figure 2-9. Conceptual Hydrostratigraphic Column for the 100-B/C Area.

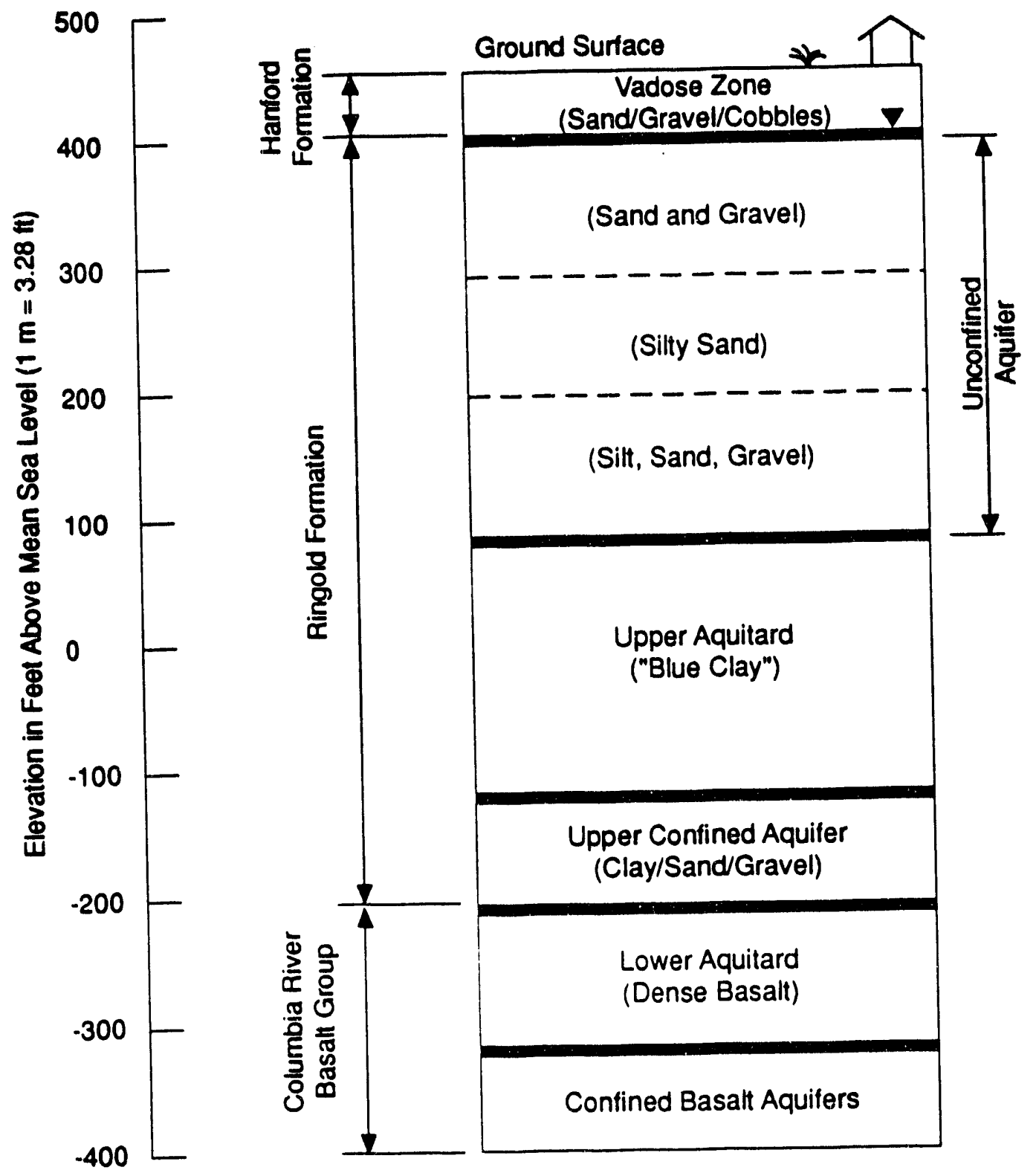


DOE/RL-91-07, Rev. 0

Figure 2-10. Map of the Monitoring Wells in the 100-B/C Area.

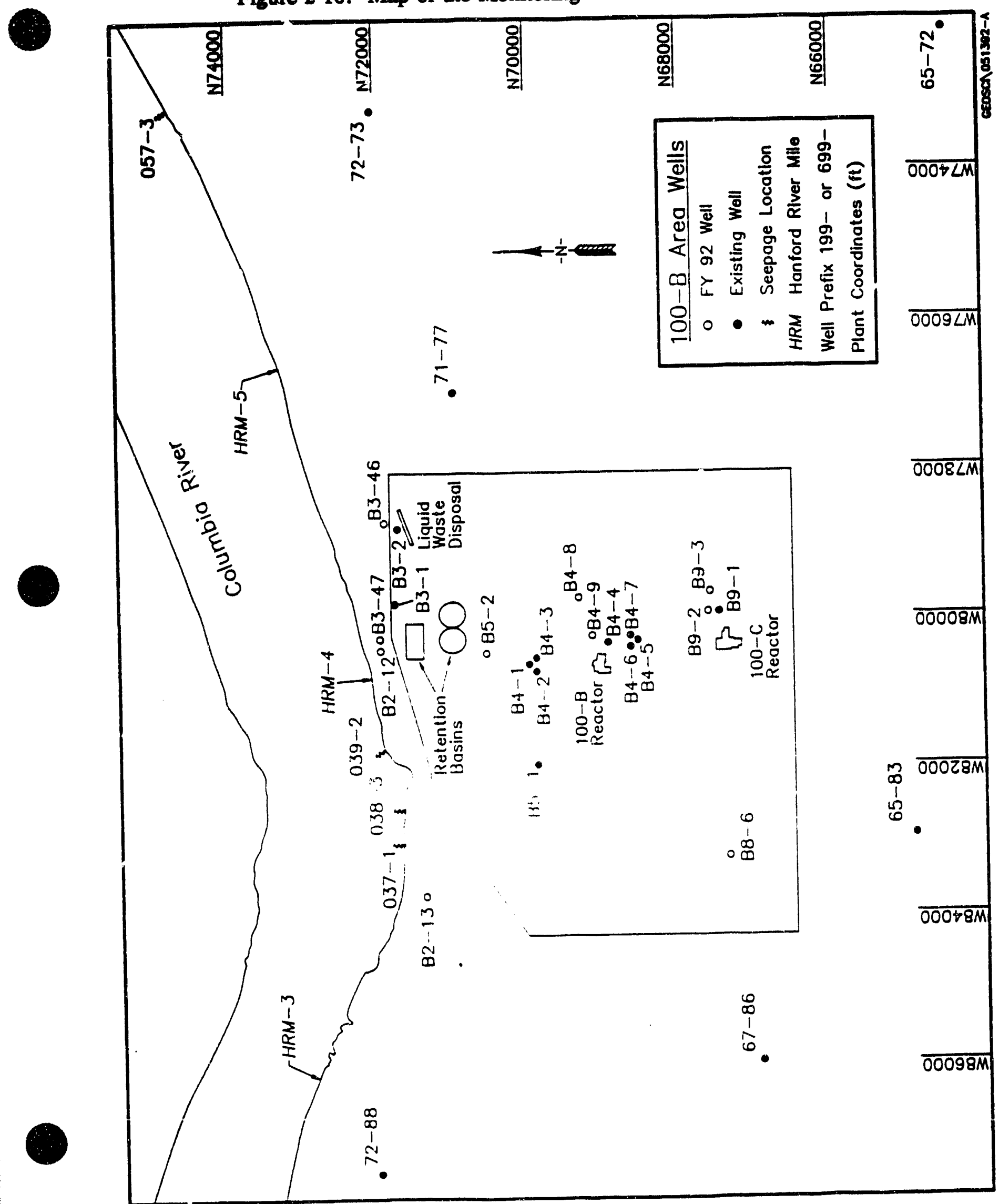


Figure 2-11. Geologic and Well Construction Log 199-B9-1.

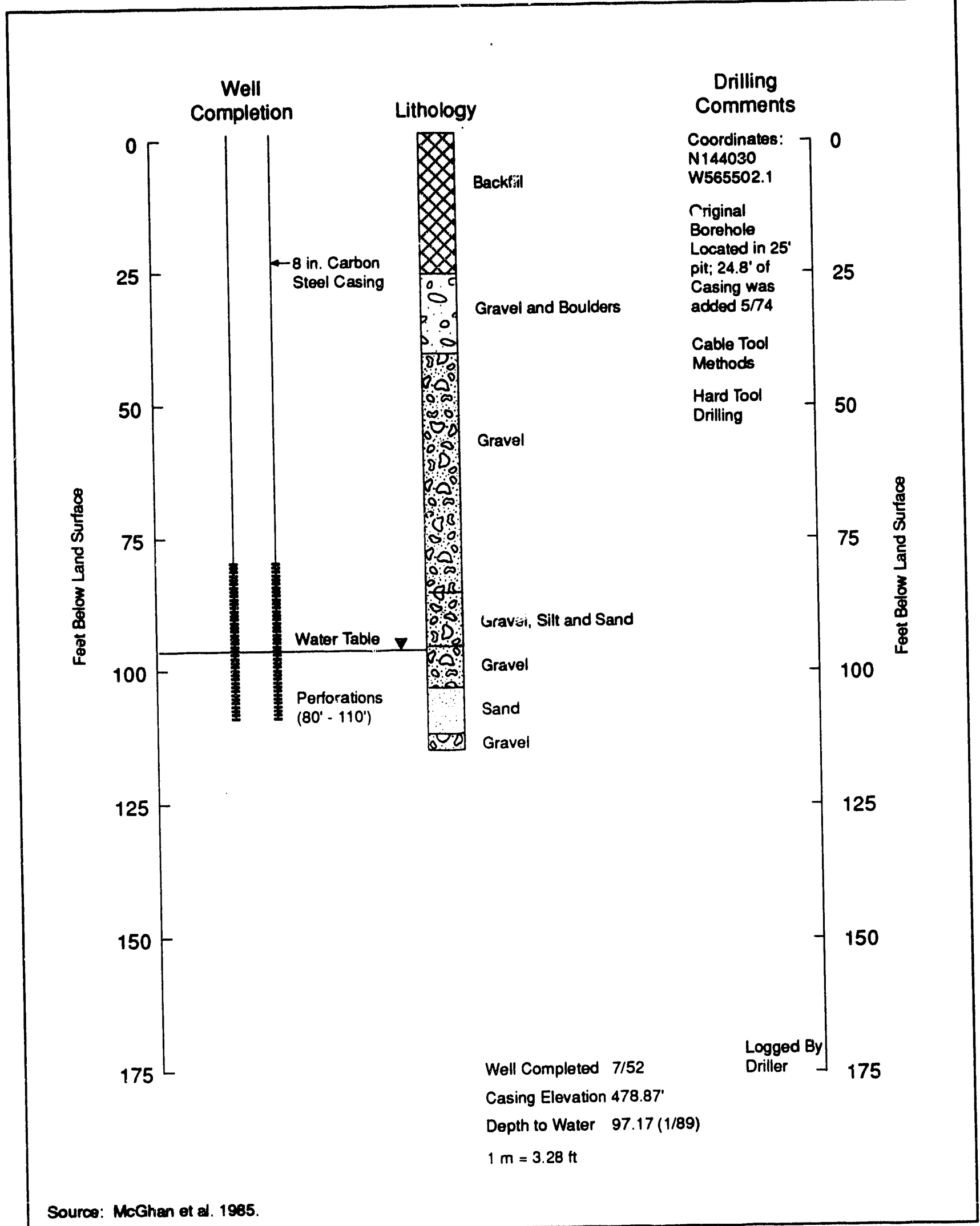


DOE/RL-91-07, Rev. 0

Figure 2-12. Well Information Sheet for Well 199-B9-2

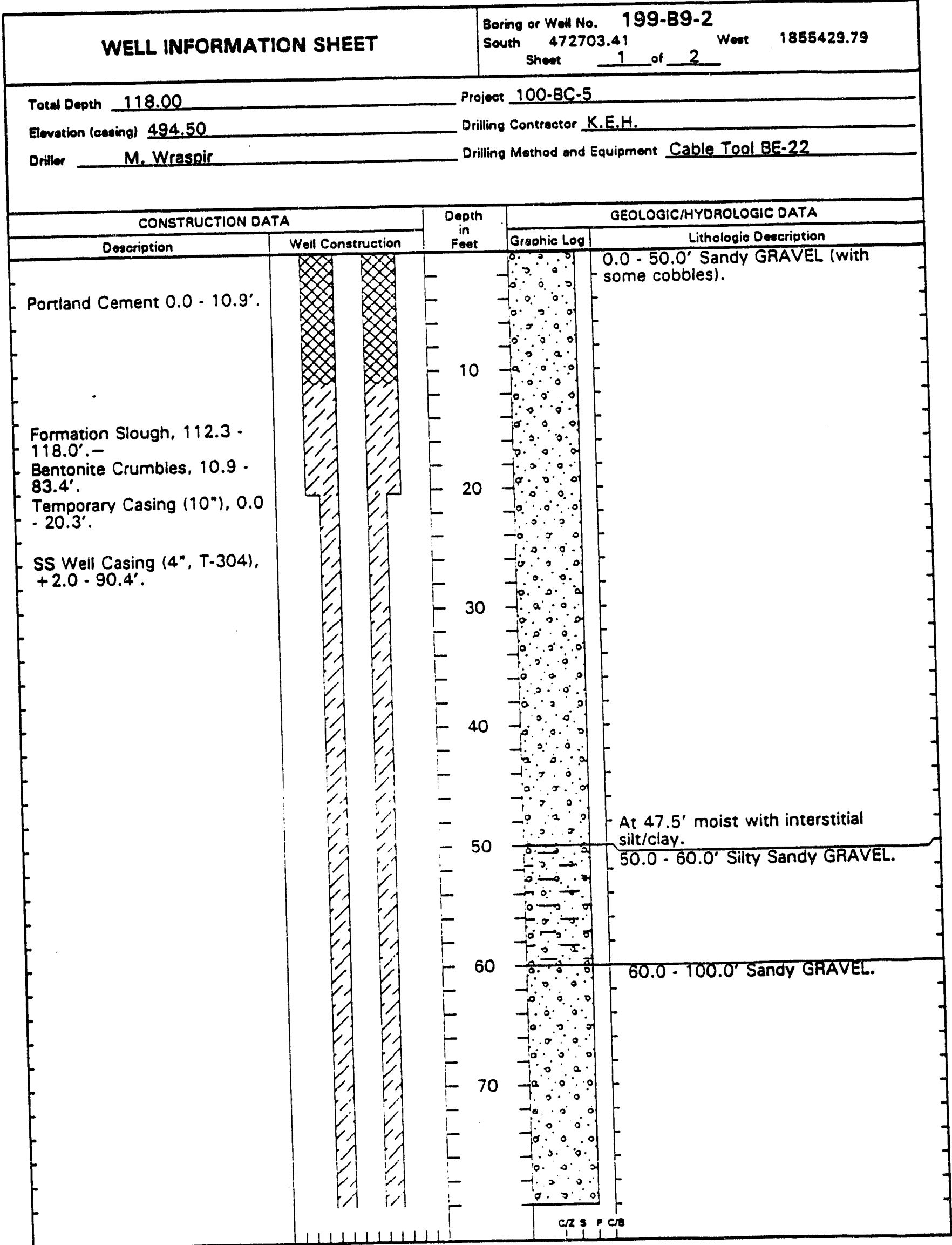


DOE/RL-91-07, Rev. 0

Figure 2-12. Well Information Sheet for Well 199-B9-2

(2 of 2)

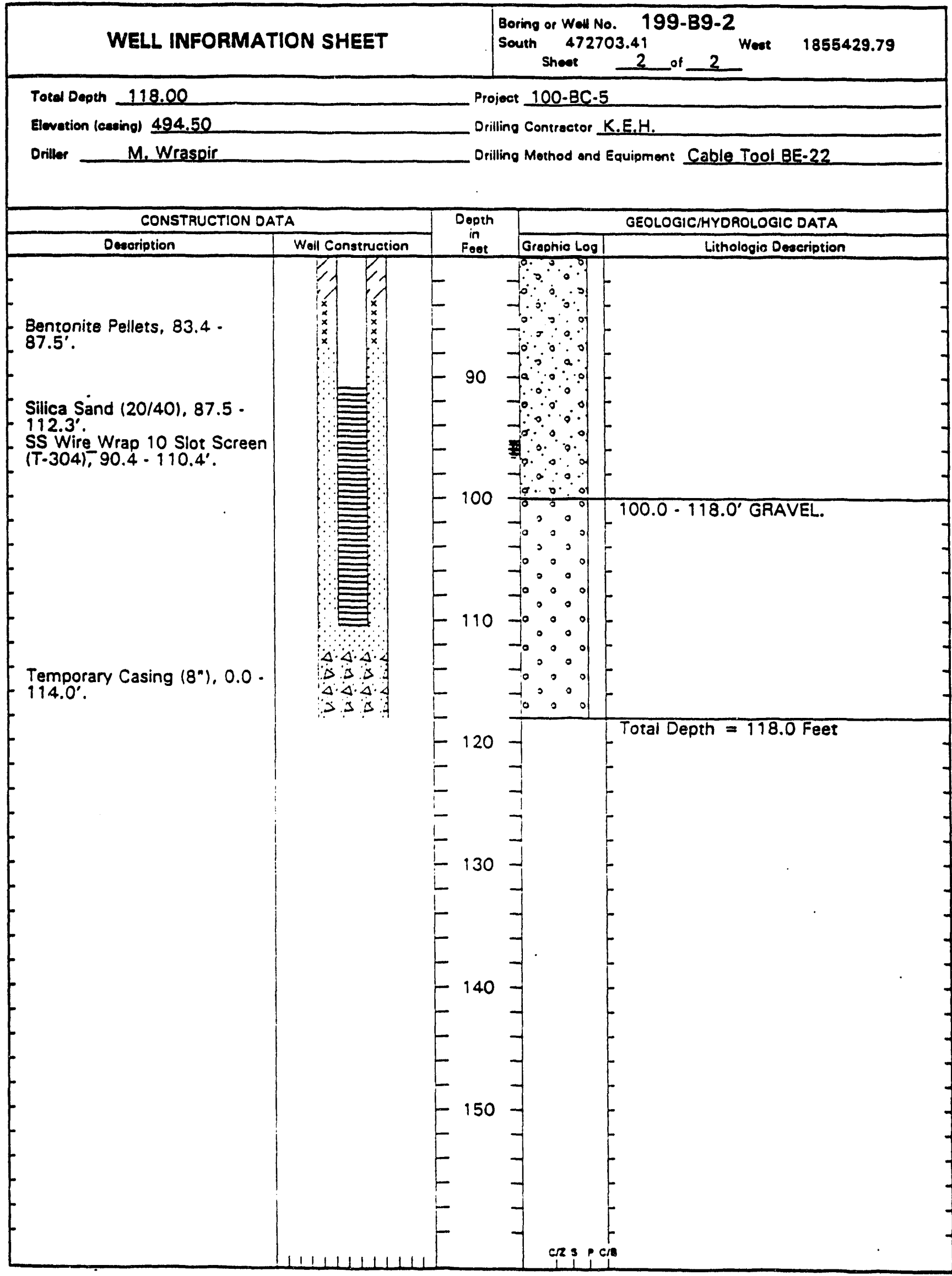


DOE/RL-91-07, Rev. 0

Figure 2-13. Well Information Sheet for Well 199-B9-3

(1 of 2)

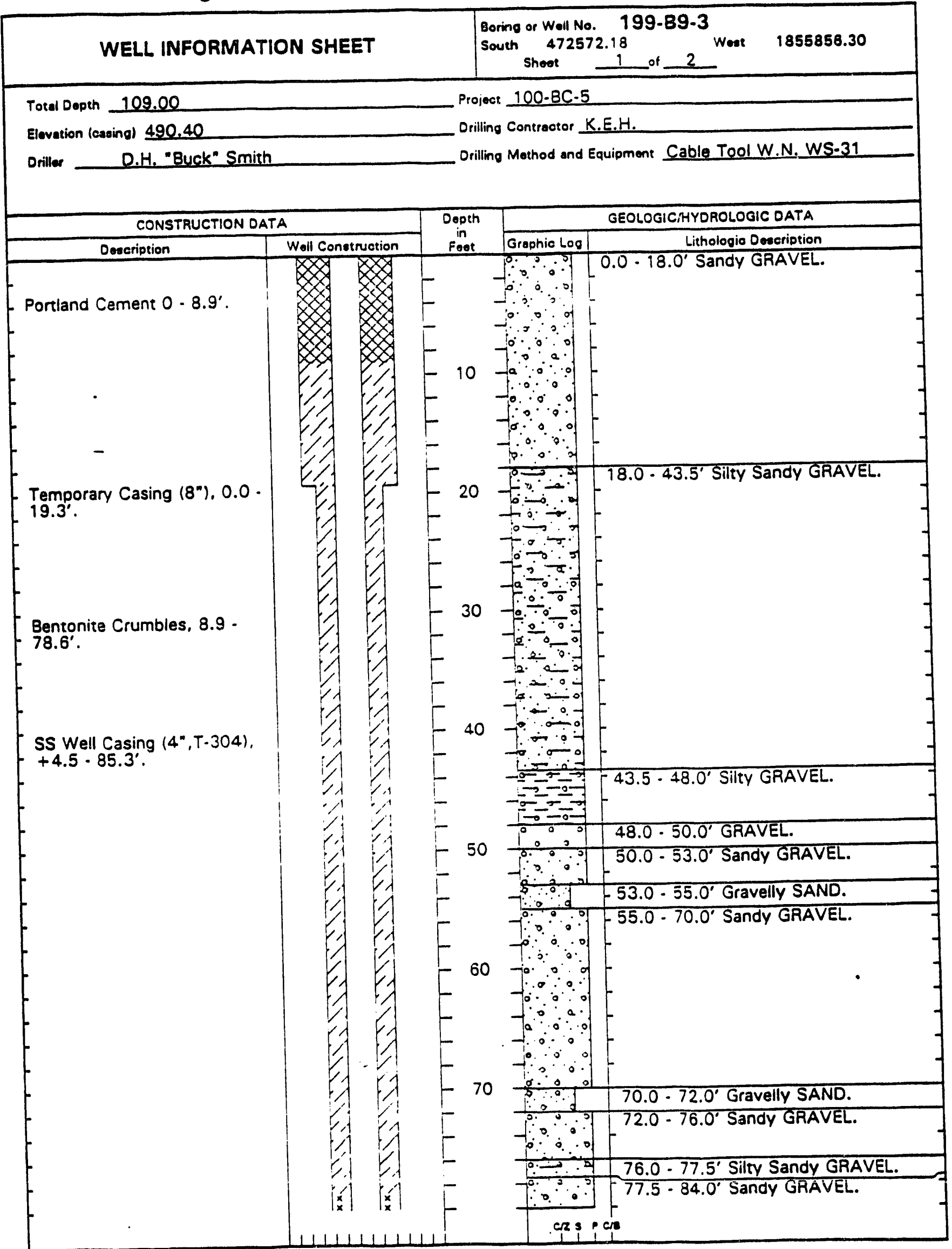


DOE/RL-91-07, Rev. 0

Figure 2-13. Well Information Sheet for Well 199-B9-3

(2 of 2)

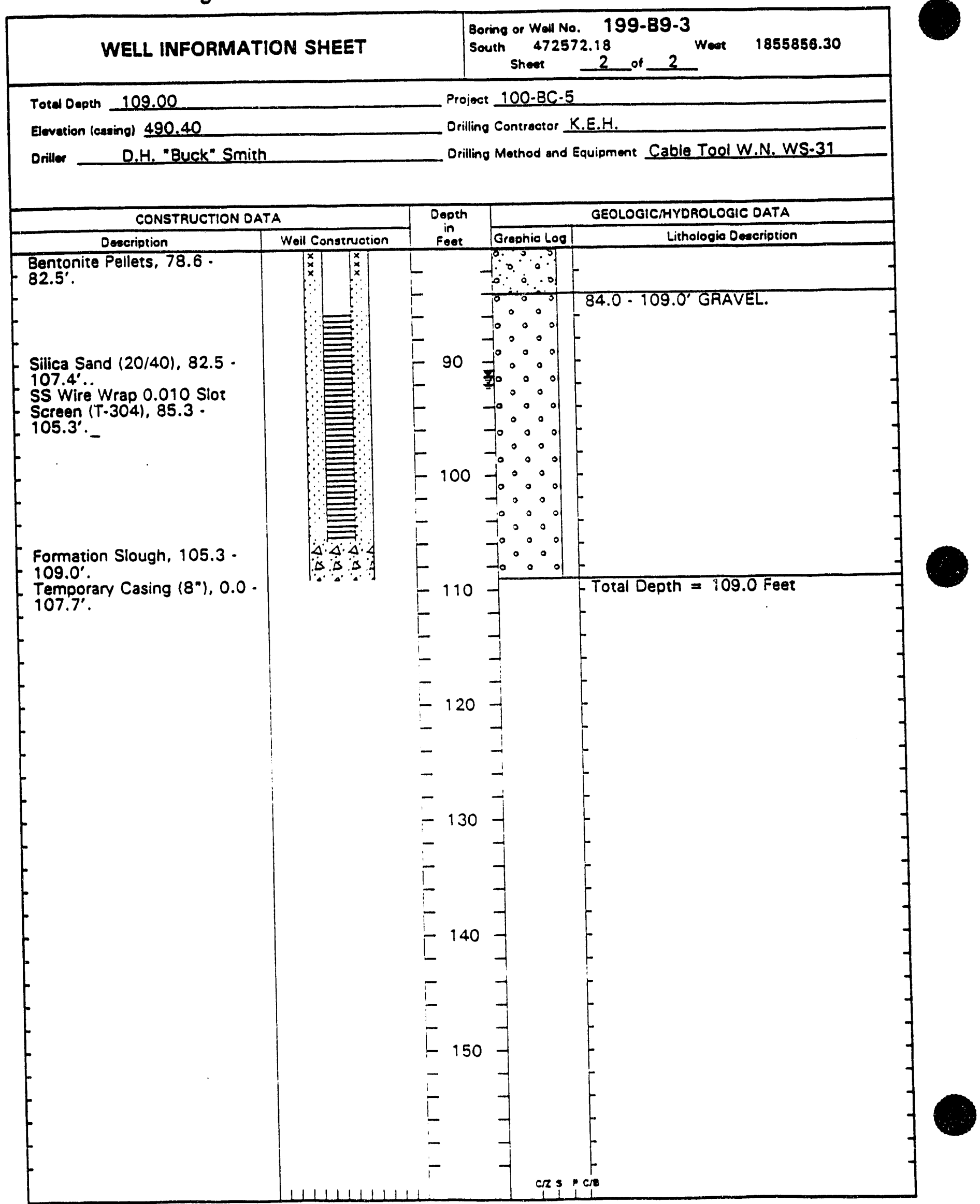


Figure 2-14. Wind Roses for the Hanford Site.

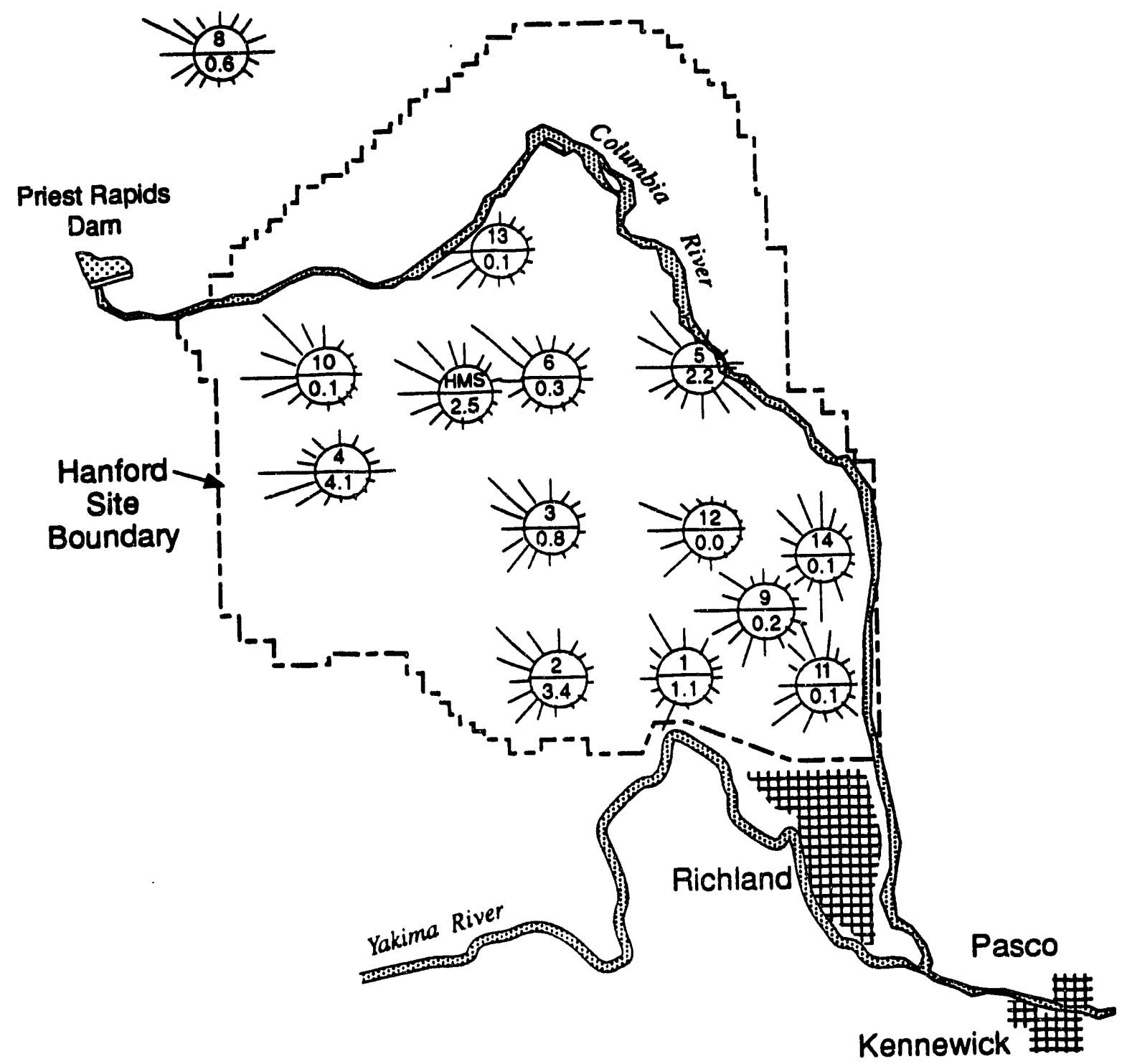

LEGEND:
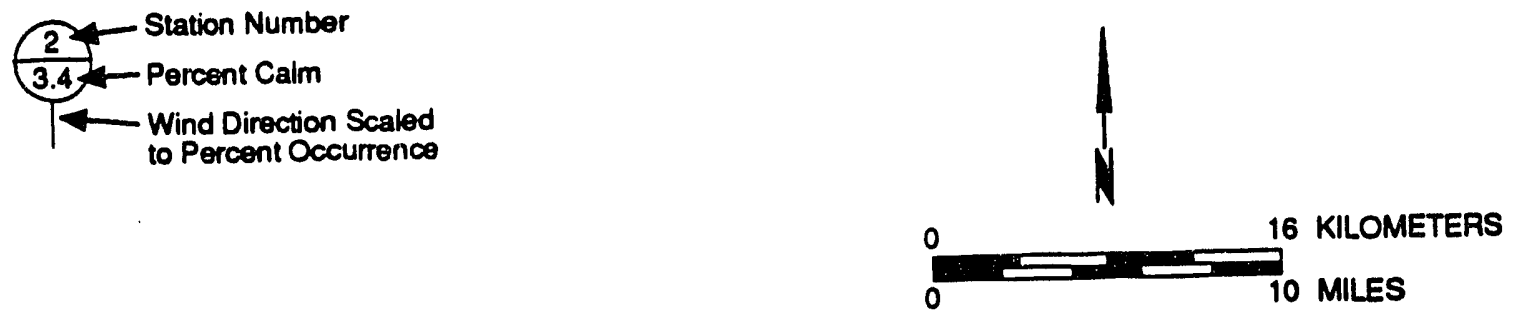
Table 2-1. Summary Description of Facilities/Potential Waste Sites Located in the 100-BC-2 Operable Unit.

\begin{tabular}{|c|c|c|c|c|c|c|c|c|}
\hline 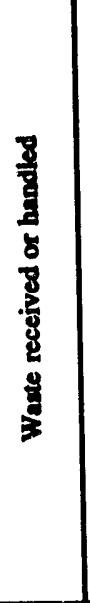 & 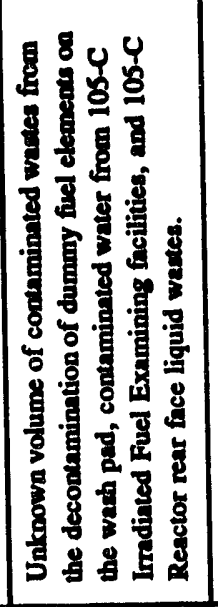 & 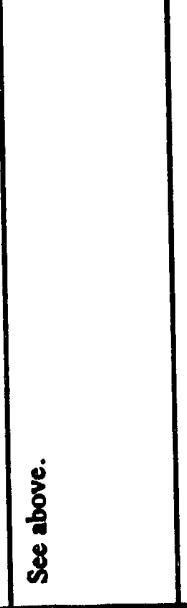 & 豙 & 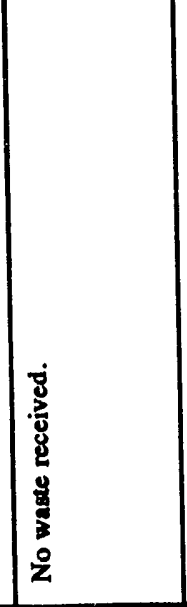 & 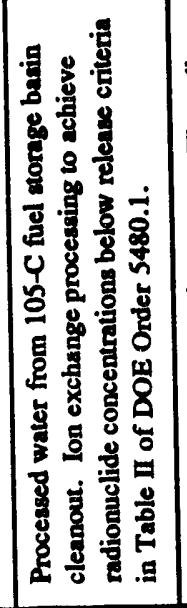 & 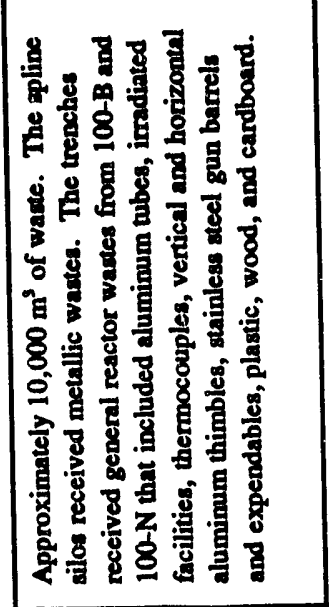 & 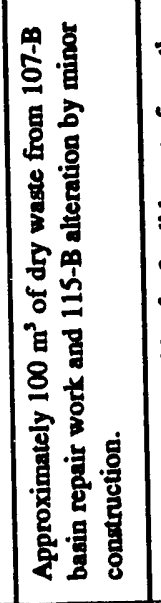 & 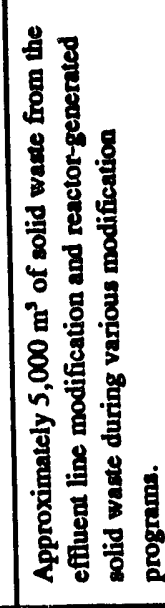 \\
\hline 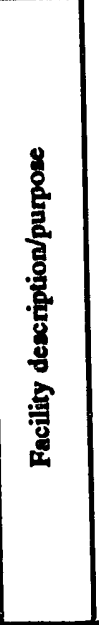 & 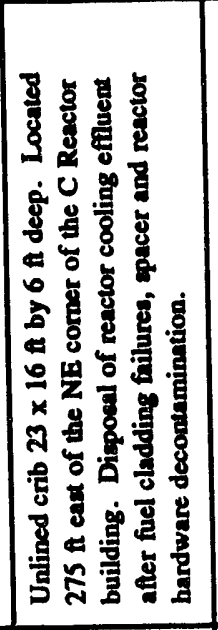 & 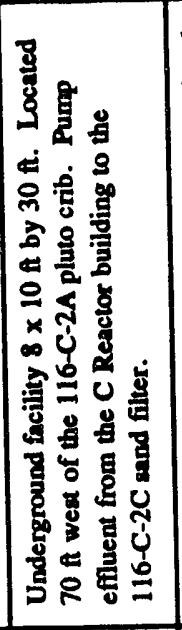 & 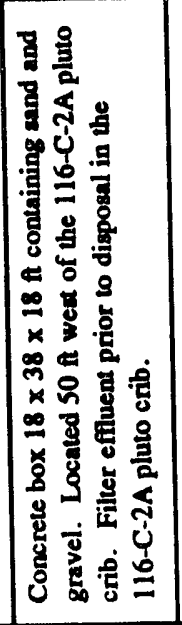 & 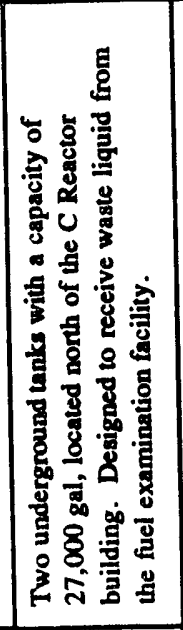 & 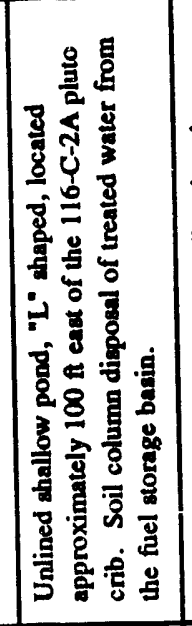 & 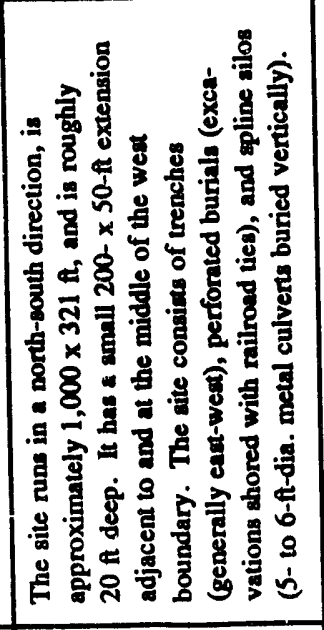 & 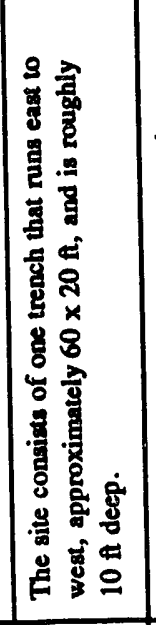 & 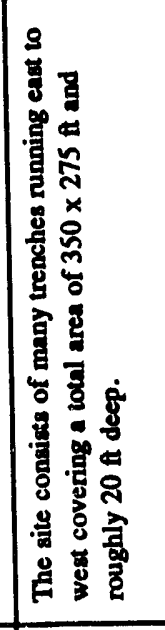 \\
\hline 焉 & 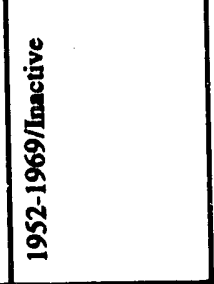 & 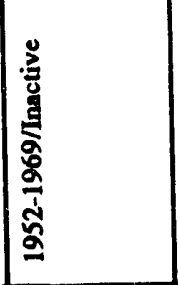 & 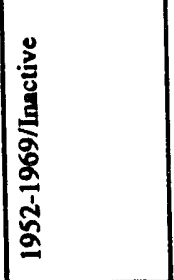 & 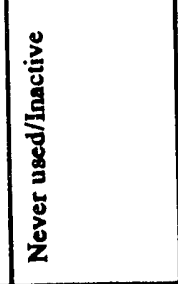 & 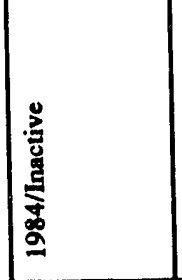 & 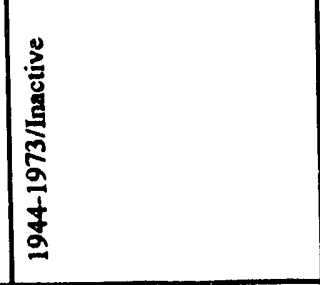 & 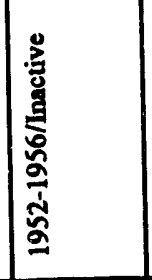 & 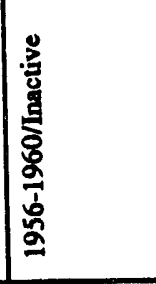 \\
\hline$\frac{\mathrm{I}}{\mathrm{z}}$ & 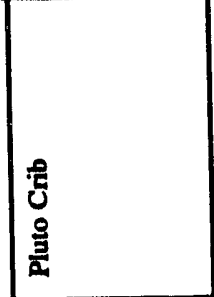 & 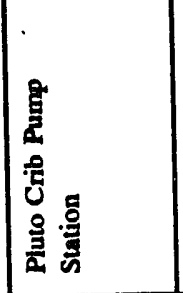 & 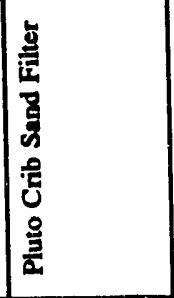 & 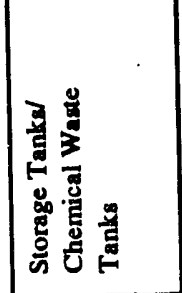 & 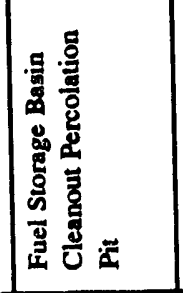 & 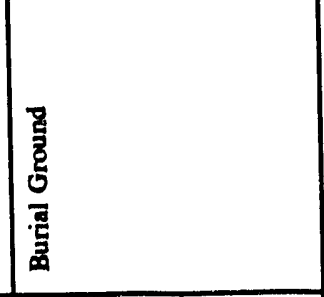 & 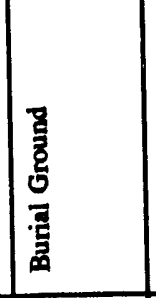 & 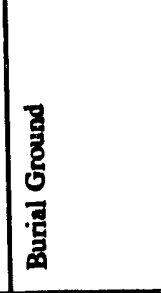 \\
\hline 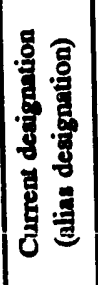 & 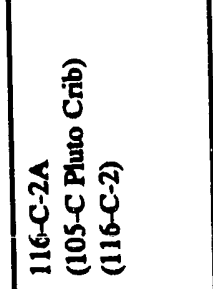 & 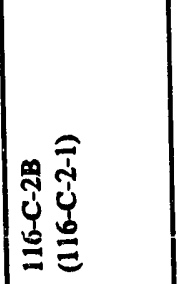 & 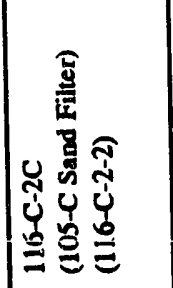 & 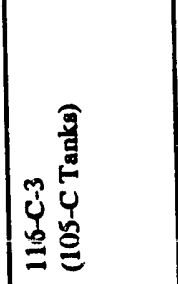 & 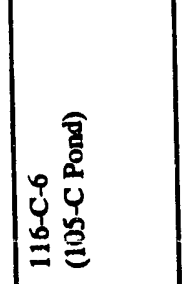 & 舅 & 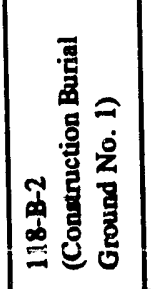 & 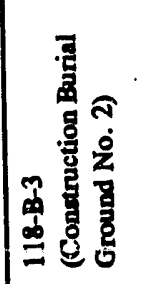 \\
\hline
\end{tabular}


Table 2-1. Summary Description of Facilities/Potential Waste Sites Located in the 100-BC-2 Operable Unit.

\begin{tabular}{|c|c|c|c|c|c|c|c|c|}
\hline 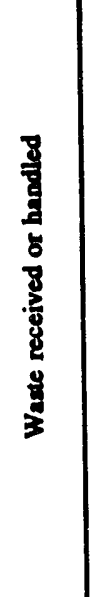 & 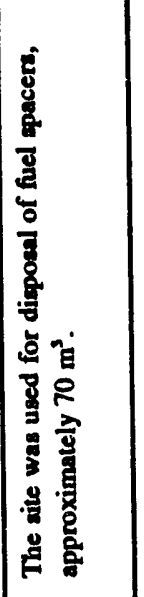 & 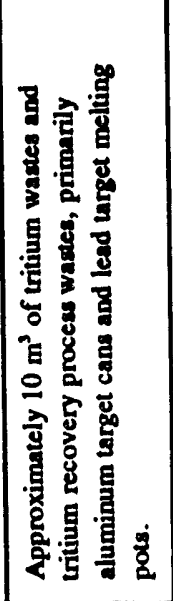 & 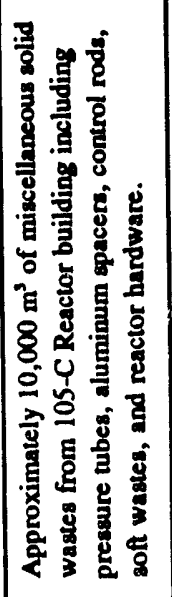 & 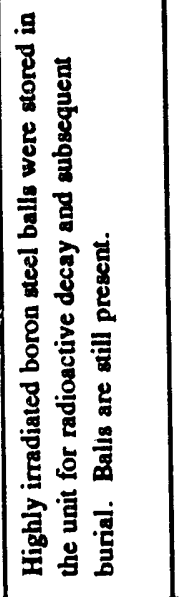 & 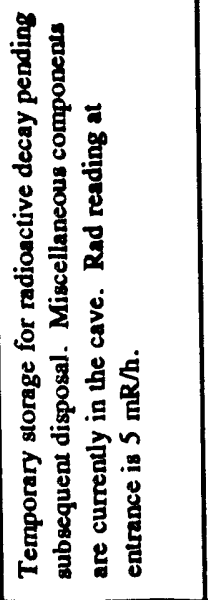 & 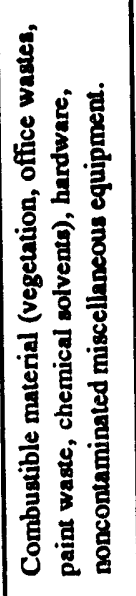 & 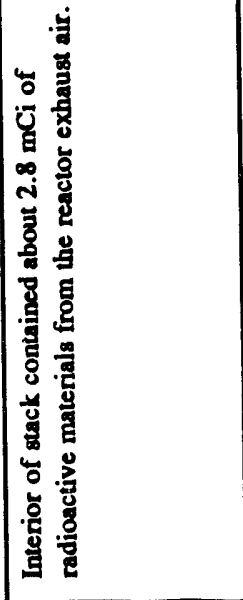 & 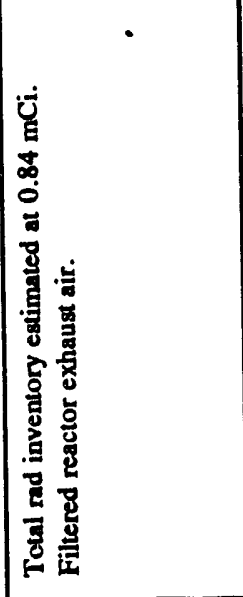 \\
\hline 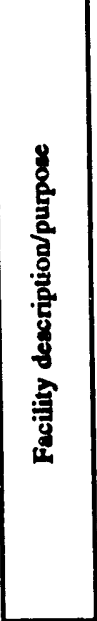 & 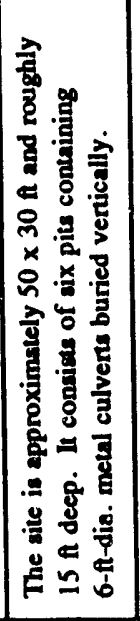 & 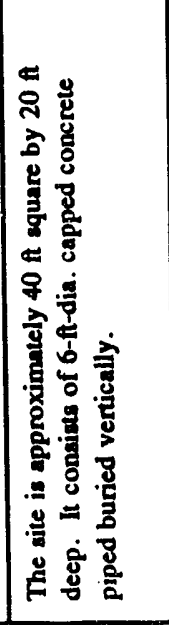 & 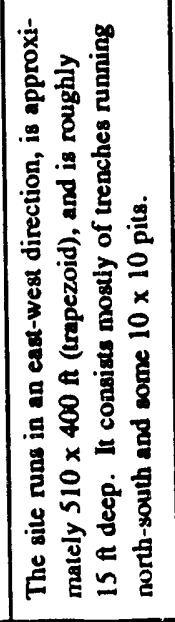 & 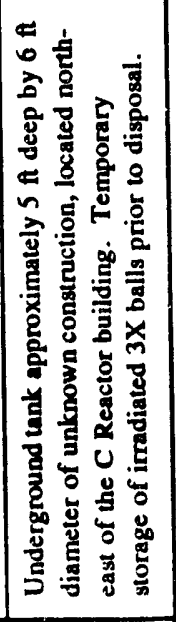 & 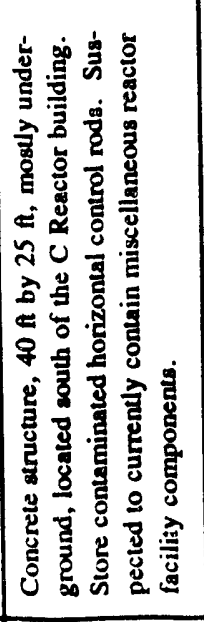 & 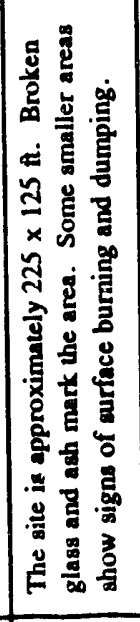 & 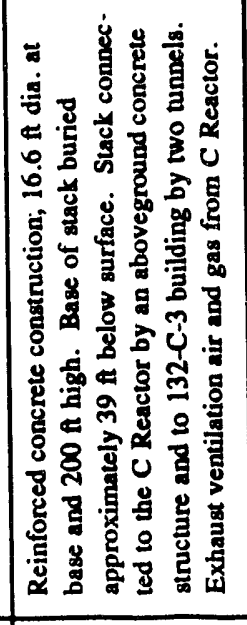 & 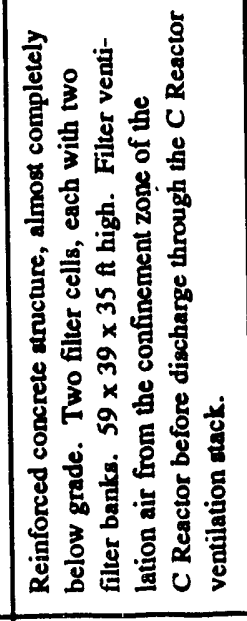 \\
\hline 量 & 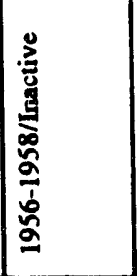 & 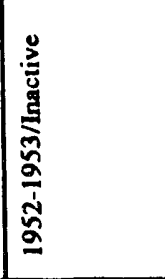 & 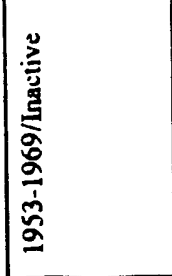 & 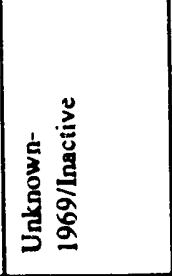 & 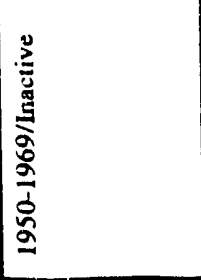 & 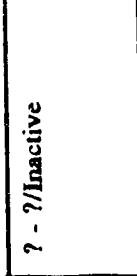 & 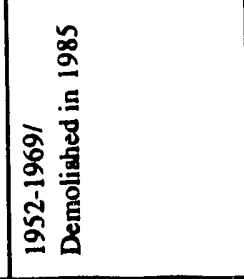 & 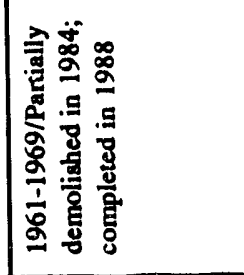 \\
\hline 噌 & 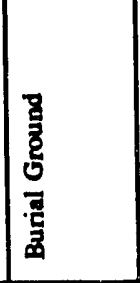 & 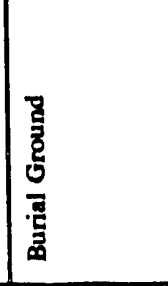 & 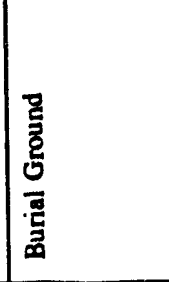 & 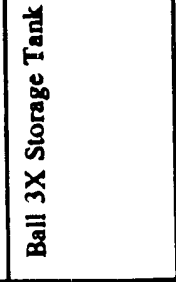 & 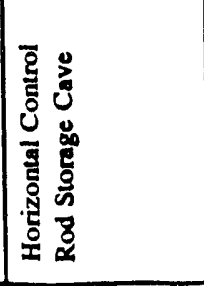 & 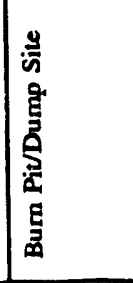 & 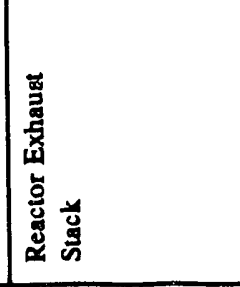 & 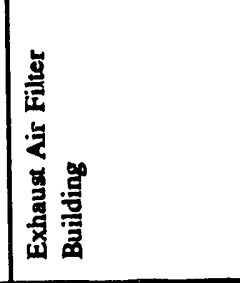 \\
\hline 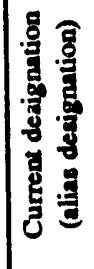 & 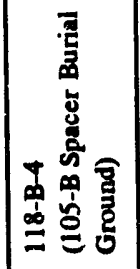 & 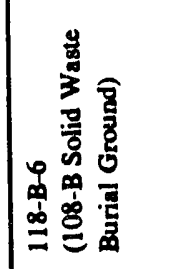 & 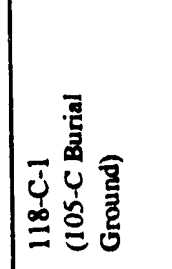 & $\begin{array}{l}\tilde{\bigcup} \\
ٍ \\
ٍ\end{array}$ & $\mid \begin{array}{l}0 \\
0 \\
\infty \\
\Xi\end{array}$ & 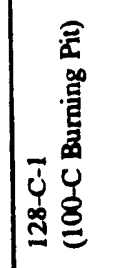 & 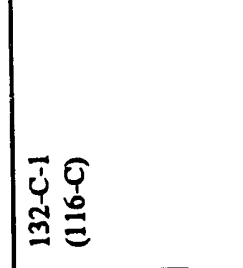 & 仓̊ํㅗ \\
\hline
\end{tabular}


DOE/RL-91-07, Rev. 0

Table 2-1. Summary Description of Facilities/Potential Waste Sites Located in the 100-BC-2 Operable Unit.

(3 of 4)

\begin{tabular}{|c|c|c|c|c|c|c|c|c|}
\hline 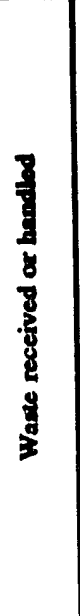 & 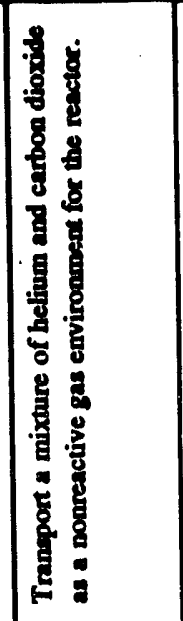 & 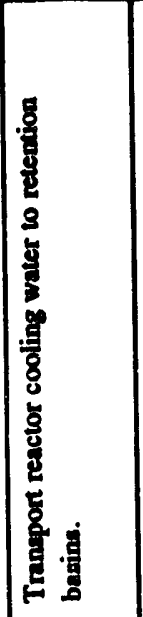 & 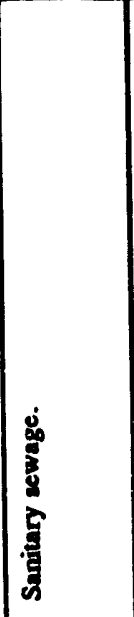 & 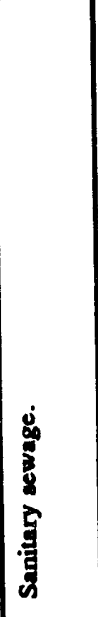 & 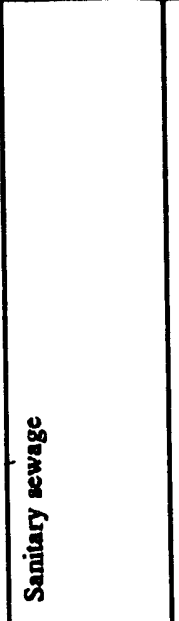 & 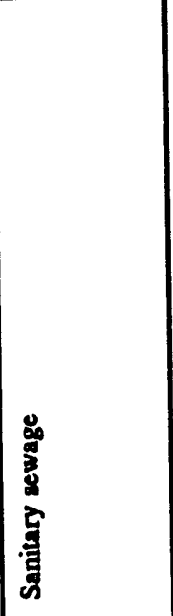 & 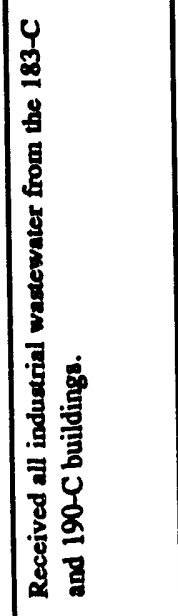 & 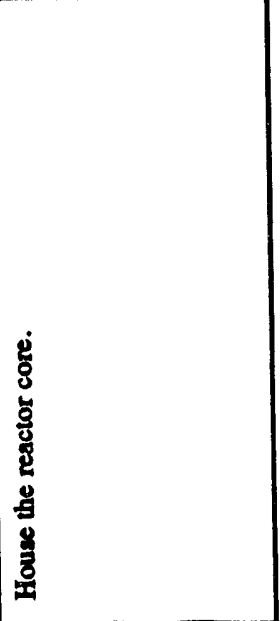 \\
\hline 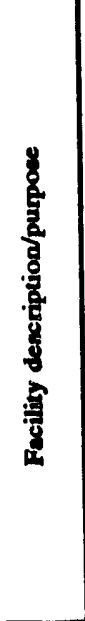 & 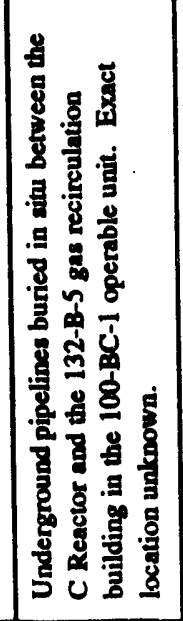 & 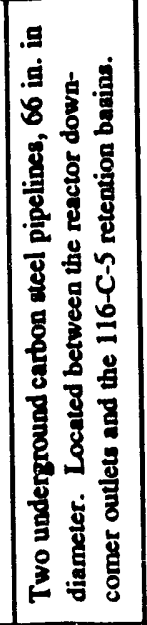 & 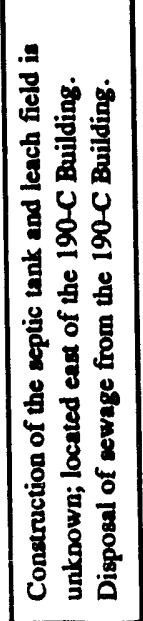 & 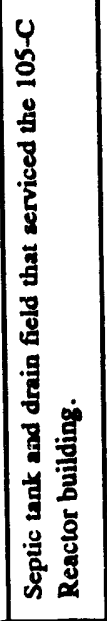 & 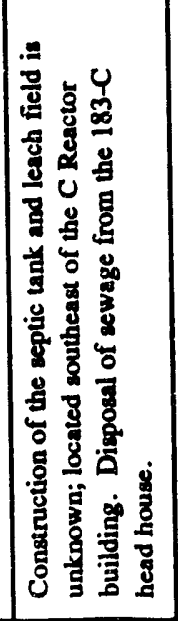 & 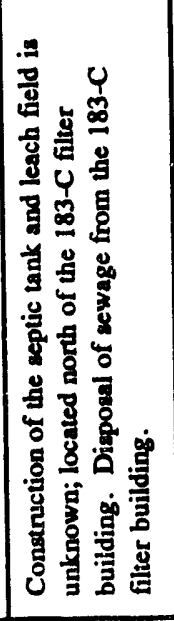 & 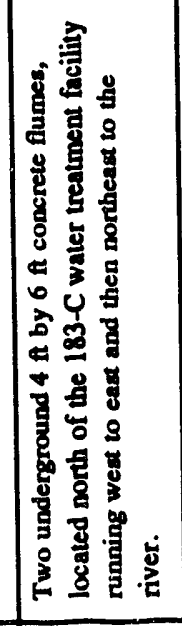 & 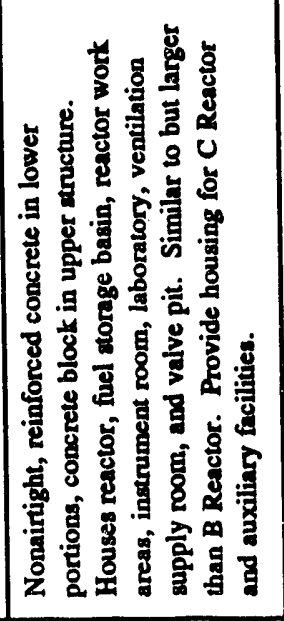 \\
\hline 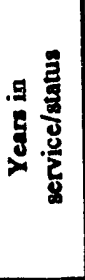 & 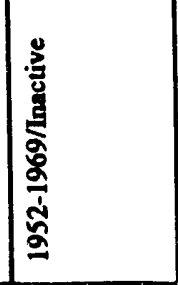 & 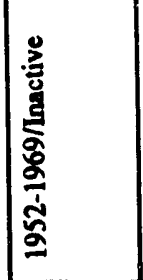 & 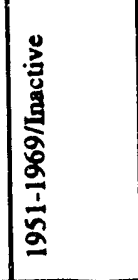 & 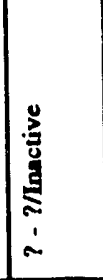 & 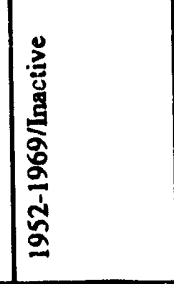 & 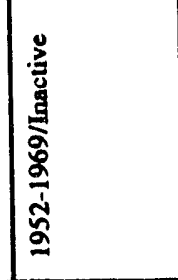 & 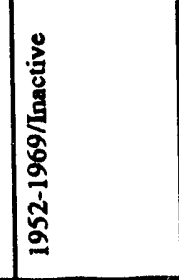 & 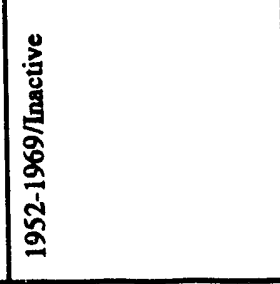 \\
\hline$\frac{\mathrm{g}}{2}$ & & & 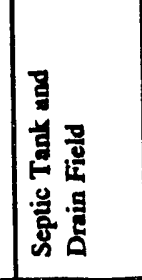 & 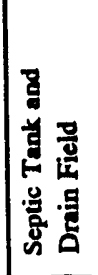 & 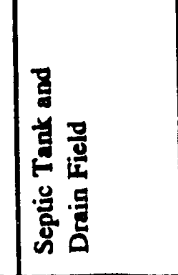 & 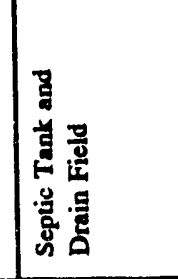 & & 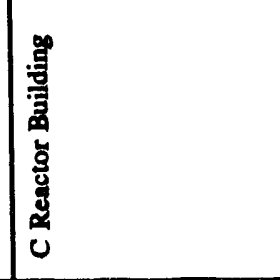 \\
\hline 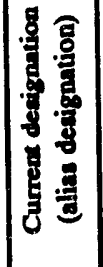 & 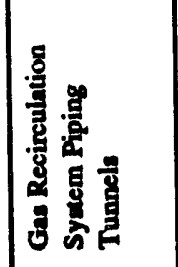 & 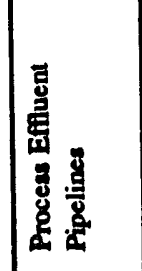 & 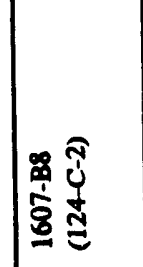 & 要 & $\begin{array}{l}0 \\
8 \\
8 \\
8 \\
8 \\
-10\end{array}$ & 票 & 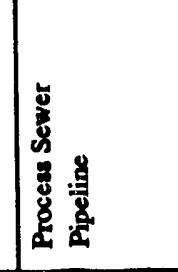 & 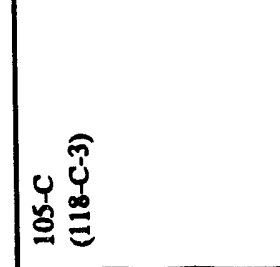 \\
\hline
\end{tabular}

WP 2T-1c 
Table 2-1. Summary Description of Facilities/Potential Waste Sites Located in the 100-BC-2 Operable Unit.

(4 of 4)

\begin{tabular}{|c|c|c|c|c|c|c|}
\hline 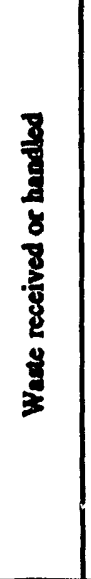 & 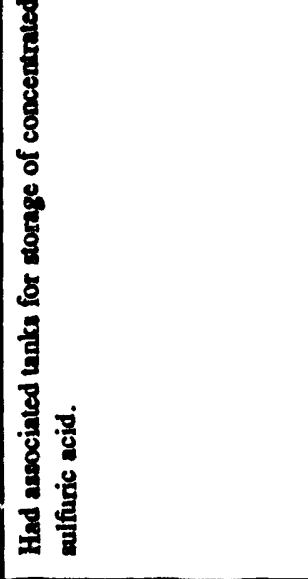 & & & 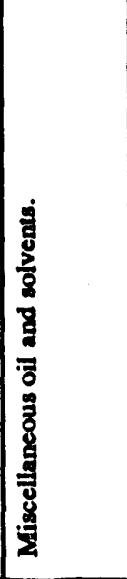 & & 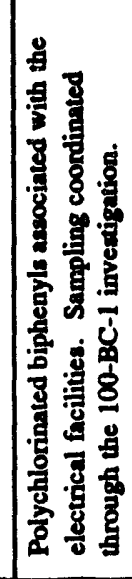 \\
\hline 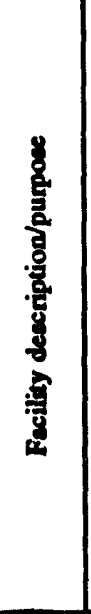 & 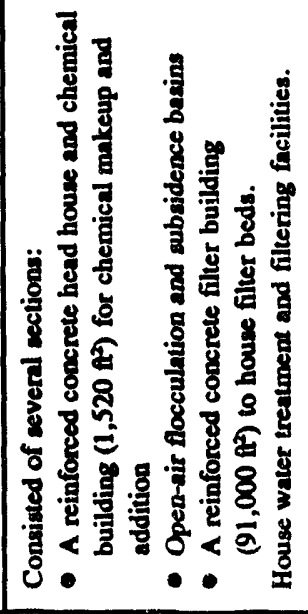 & 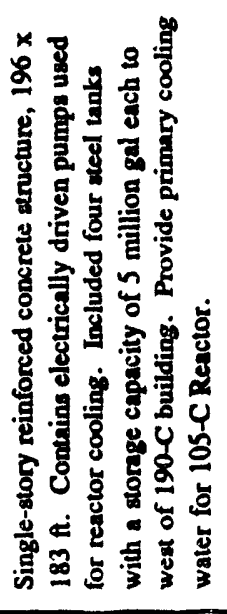 & 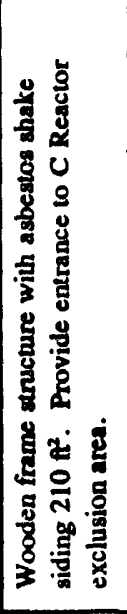 & 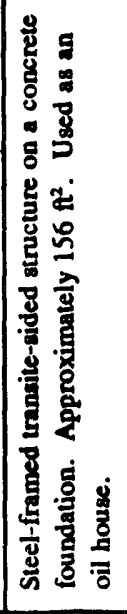 & 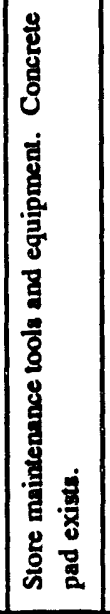 & 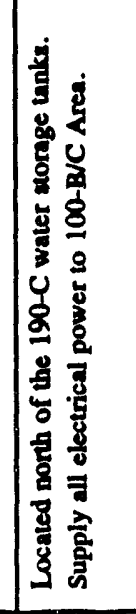 \\
\hline 量 & 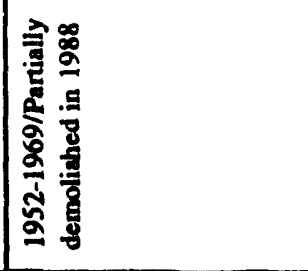 & 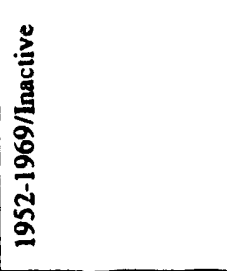 & 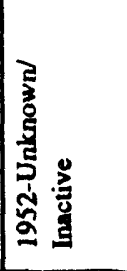 & 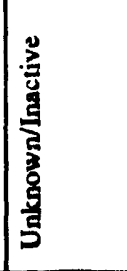 & 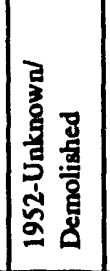 & 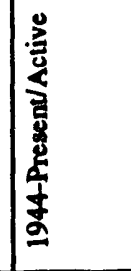 \\
\hline$\frac{1}{2}$ & 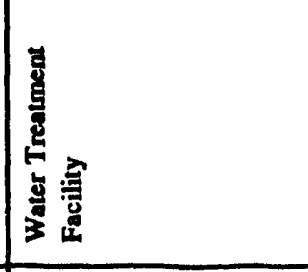 & 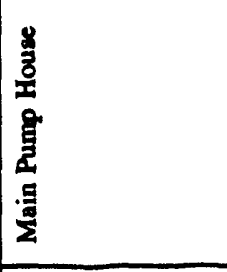 & 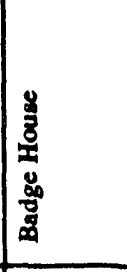 & 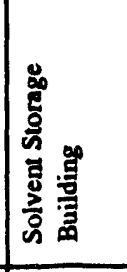 & 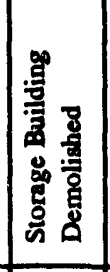 & 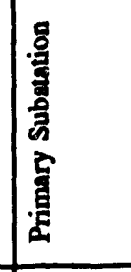 \\
\hline 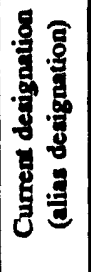 & 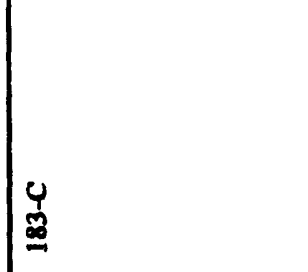 & \$ & ఏ్ & $\underline{\underline{I}}$ & 星 & $\mid \frac{\Phi}{\underline{a}}$ \\
\hline
\end{tabular}


Table 2-2. Summary of Concentrations and Inventories of Radiological Contamination at the 100-BC-2 Operable Unit Waste Units.

\begin{tabular}{|c|c|c|c|c|c|c|c|c|c|c|c|}
\hline $\mathbb{A Z}^{\prime}$ & $\begin{array}{l}8 \\
+ \\
+ \\
\vdots \\
\vdots \\
-\end{array}$ & 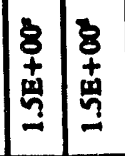 & 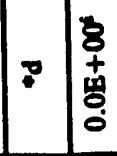 & 装 & 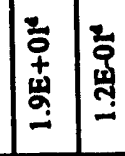 & 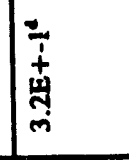 & 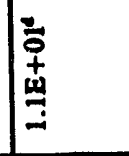 & 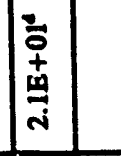 & 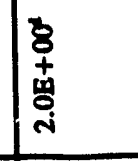 & & 总 \\
\hline 2 & $:$ & 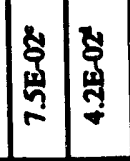 & $: \begin{array}{l}0 \\
0 \\
1 \\
0 \\
0 \\
0\end{array}$ & 8 & 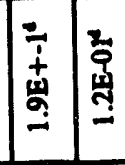 & $\begin{array}{l}8 \\
+ \\
+ \\
\text { 龺 } \\
-\end{array}$ & $\mid$ & 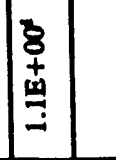 & 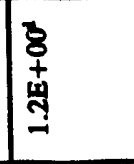 & & 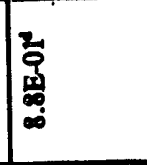 \\
\hline 国 & 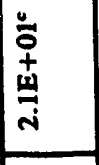 & 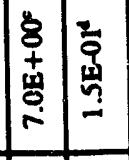 & 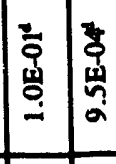 & $:$ & 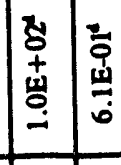 & 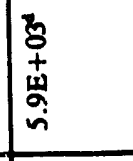 & 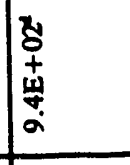 & 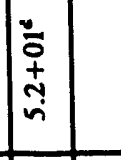 & 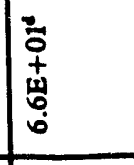 & & 7 \\
\hline 葍 & 品 & 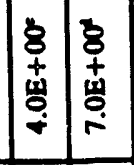 & 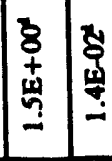 & $\begin{array}{l}8 \\
+ \\
+4 \\
7 \\
7\end{array}$ & 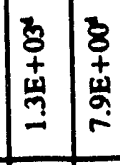 & 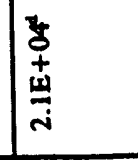 & 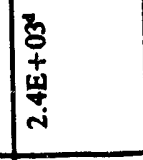 & $:$ & 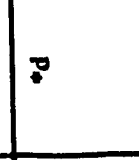 & & 7 \\
\hline 0 & 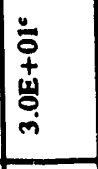 & 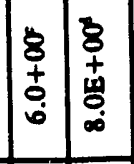 & 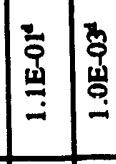 & 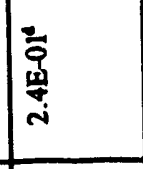 & 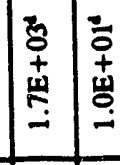 & 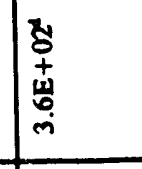 & 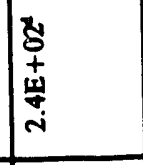 & 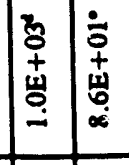 & 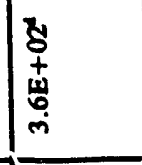 & & 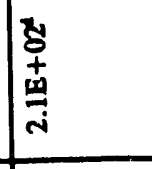 \\
\hline$\frac{2}{2}$ & 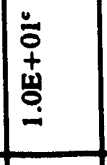 & 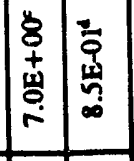 & 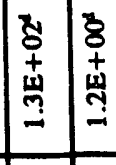 & 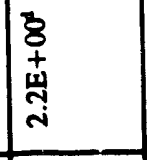 & 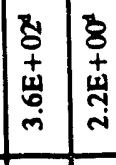 & 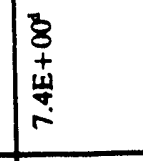 & 落 & 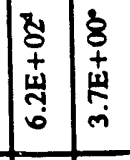 & 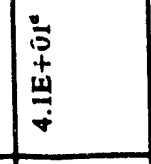 & & 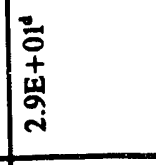 \\
\hline $\bar{z}$ & 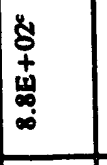 & 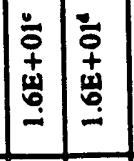 & & & & & & & & & \\
\hline 8 & 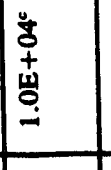 & 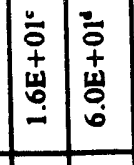 & 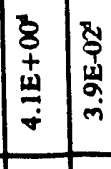 & 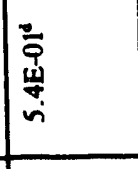 & 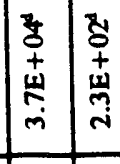 & 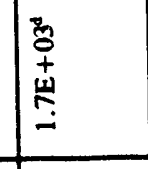 & 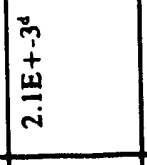 & 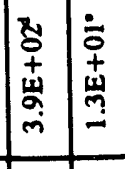 & 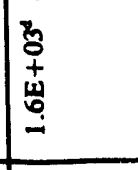 & & 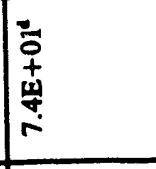 \\
\hline 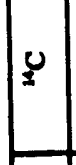 & 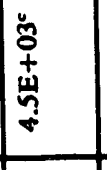 & & & & & 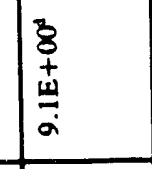 & 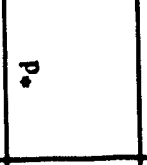 & 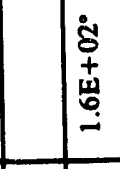 & & 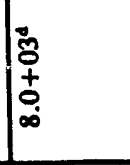 & 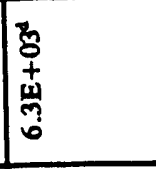 \\
\hline$\mp$ & 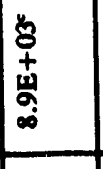 & 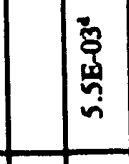 & 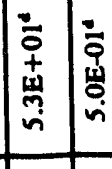 & 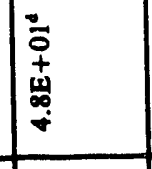 & 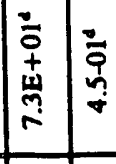 & & & \begin{tabular}{|l}
$\dot{0}$ \\
$\dot{+}$ \\
参 \\
$\dot{\sigma}$ \\
\end{tabular} & & 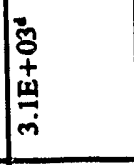 & 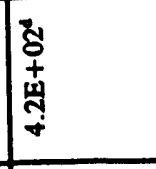 \\
\hline 量 & \begin{tabular}{|l}
0 \\
0 \\
to \\
\\
\end{tabular} & 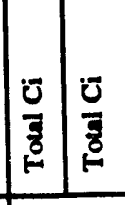 & 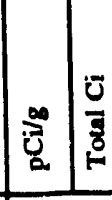 & : & 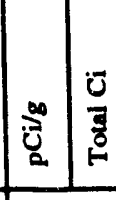 & : & $\vec{z}_{2}^{\infty}$ & 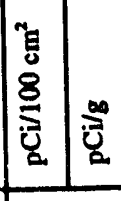 & $\begin{array}{l}1 \\
8 \\
8 \\
8 \\
0\end{array}$ & $\begin{array}{l}3 \\
8 \\
8 \\
8 \\
0 \\
0 \\
\end{array}$ & $\begin{array}{l}3 \\
8 \\
8 \\
0 \\
0 \\
\end{array}$ \\
\hline 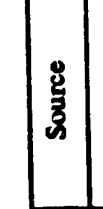 & 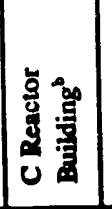 & 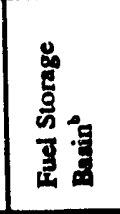 & 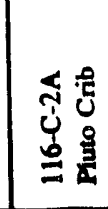 & 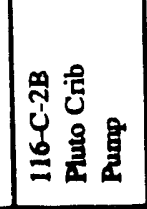 & 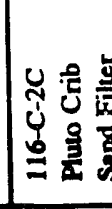 & 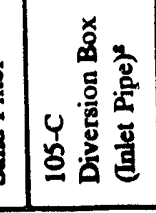 & 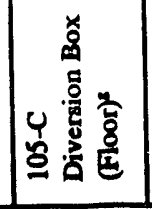 & 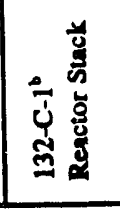 & 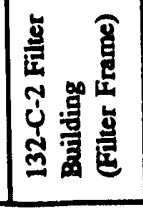 & 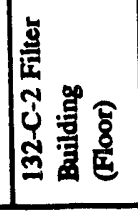 & 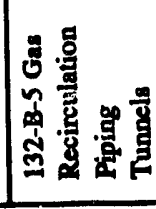 \\
\hline
\end{tabular}


Table 2-2. Summary of Concentrations and Inventories of Radiological Contamination at the 100-BC-2 Operable Unit Waste Units.

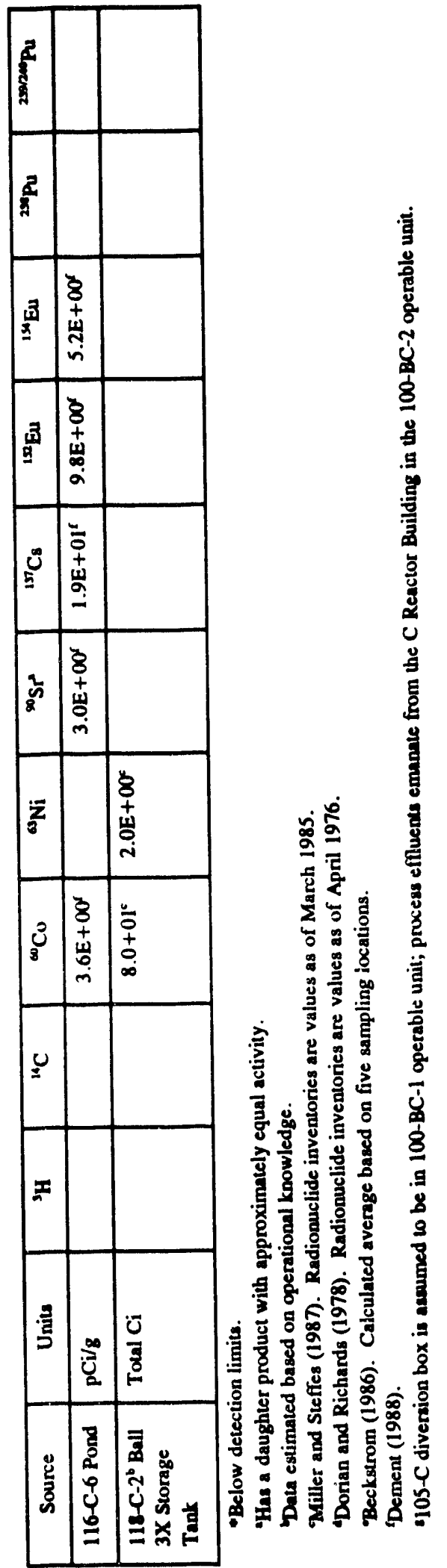


Table 2-3. 116-C-2A Pluto Crib System Radiological Sampling Results.

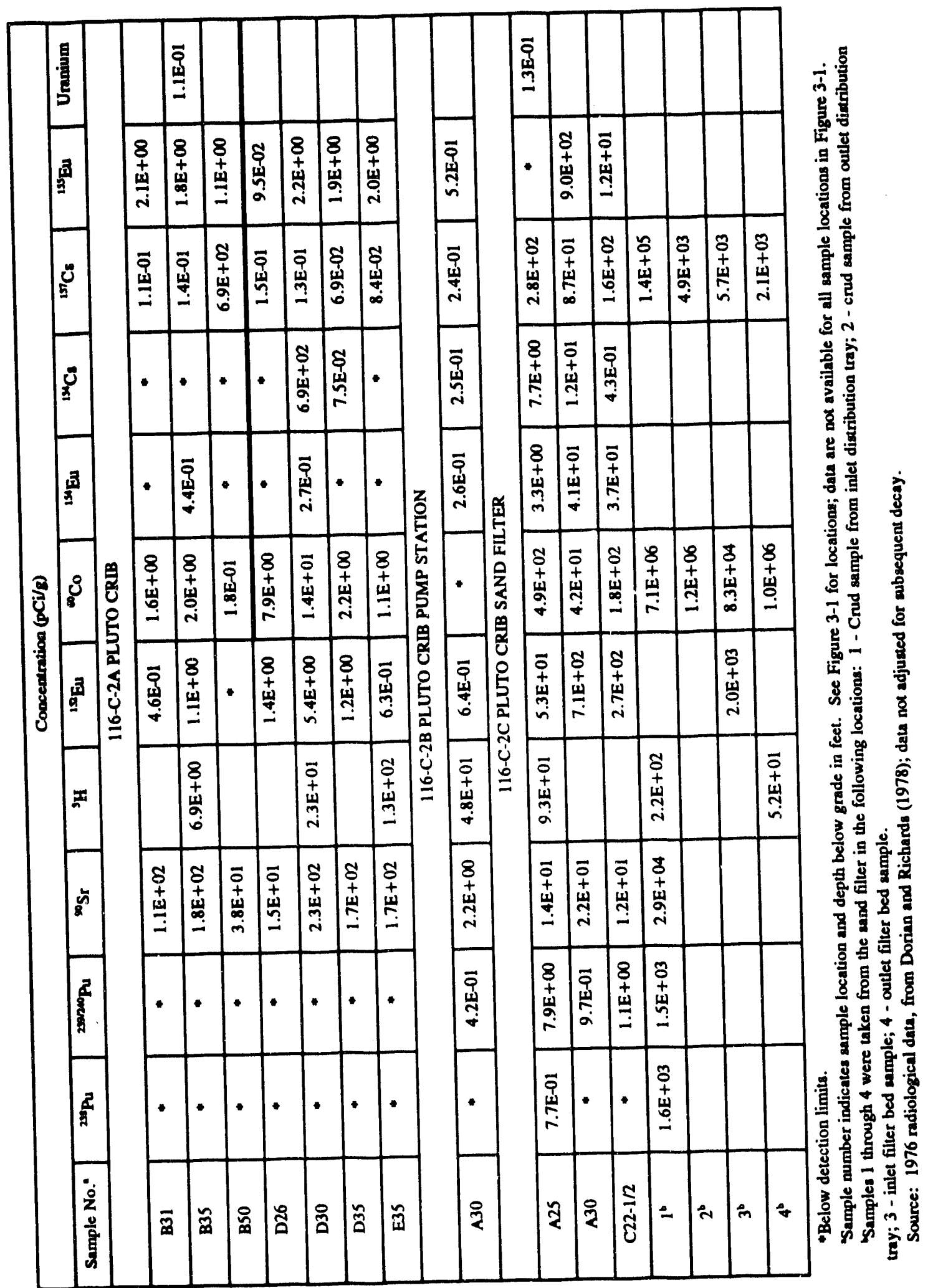


DOE/RL-91-07, Rev. 0

Table 2-4. 132-C-1 Reactor Exhaust Stack Core Sample Analytical Data.

\begin{tabular}{|c|c|c|c|c|c|}
\hline$\frac{\pi}{2}$ & $\cdots$ & $\ldots$ & $\cdots$ & $\cdots$ & $\ldots$ \\
\hline 疍 & $\cdots$ & $\cdots$ & $\cdots$ & $\cdots$ & $\ldots$ \\
\hline$\underset{\underline{Z}}{\underline{\underline{Z}}}$ & 空会・ & 至会令 & 至会主 & 立会会 & 爷是会 \\
\hline 胥 & 量会. & 至至豆 & 空全是 & 至会全 & 是是咞 \\
\hline $\int_{-\infty}^{8}$ & $\approx \hat{n} \cdot$ & $\approx \underline{g}=$ & 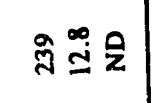 & है & $\hat{g} 00$ \\
\hline$\grave{b}$ & $\ldots$ & $\cdots$ & $\cdots$ & $\cdots$ & $\overline{3}+9$ \\
\hline $\bar{z}$ & $\cdots$ & $\cdots$ & $\cdots$ & $\cdots$ & $\cdots$ \\
\hline ¿ & $=\overline{0}$. & $\simeq \Xi \mathrm{z}$ & $\approx \eta \hat{z}$ & $2 \infty \stackrel{t}{0}$ & 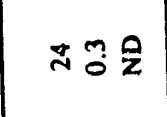 \\
\hline ֻ & $\cdots$ & $\ldots$ & $\cdots \cdot$ & $\cdots$ & $\cong \Xi \Xi$ \\
\hline$=$ & $\cdots$ & $\cdots$ & $\cdots$ & $\cdots$ & б苛电 \\
\hline 造 & - & 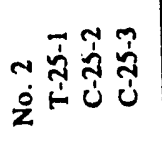 & 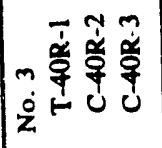 & 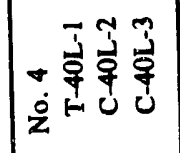 & 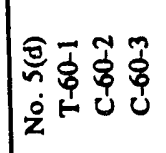 \\
\hline 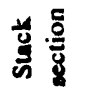 & - & N & m & & + \\
\hline
\end{tabular}




\subsection{INITIAL EVALUATION}

This chapter provides an initial evaluation of contamination in the 100-BC-2 operable unit. It includes a summary of available information on contaminants, an evaluation of potential applicable or relevant and appropriate requirements (ARAR), a preliminary site conceptual model of contaminant transport and an evaluation of the potential impacts to human health and the environment.

\subsection{KNOWN AND SUSPECTED CONTAMINATION}

Aside from recent LFI in the 100-BC-1 and 100-BC-5 operable units, the most current knowledge of radioactive contamination in the 100 Areas is based on Dorian and Richards (1978), who sampled many of the facilities in 100-BC-2 and other operable units in the 100 Areas. The most substantial potential environmental threats from 100-BC-2 come from contaminants leaching from area soils into groundwater. These contaminants can subsequently be 'ransported to the Columbia River. Because of the source and groundwater operable unit division, preliminary remedial action objectives for the 100-BC-2 operable unit focus on preventing further contamination of groundwater.

An important consideration throughout this discussion is that revious sampling efforts in the 100-B/C Area have focused on characterizing radiological contamination with little or no sampling for hazardous chemical contaminants. Some historical data on the general use of organic and inorganic chemicals are available, but quantification of nonradioactive contaminant species has been minimal. The recent investigations in the $100-\mathrm{BC}-1$ and 100 -BC-5 operable units should provide useful data to the investigations in the $100-\mathrm{BC}-2$ operable unit, especially in regards to the analogous facility approach. The data will be reviewed and incorporated as appropriate.

Much of the available data related to the $100-\mathrm{BC}-2$ operable unit are presented and evaluated in Chapter 2; therefore, the goal here is to describe the contaminants of concern as a whole based on information presented in Chapter 2. However, data investigation and evaluation will be conducted as part of the LFI report. Data from the 100-B/C Area source data compilation will be used as appropriate and supplemented with new information generated by the 100-BC-2 investigations. Groundwater, surface water and river sediments, and biota investigations can be referenced in, Sections 3.1.3, 3.1.4, and 3.1.6, respectively, of the 100-BC-5 operable unit work plan (DOE-RL 1992b). Air investigations can be referenced in Section 3.1.5 of the 100-BC-1 operable unit work plan (DOE-RL 1992a).

\subsubsection{Sources}

The 100-BC-2 operable unit includes sources associated with the C Reactor. These sources were described in detail in Section 2.1.3 and the waste generating processes were described in Section 2.1.4. Of these sources, the 116-C-2 pluto crib system is currently 
considered to be the most significant in terms of potential impact on the groundwater since it was used for direct soil column discharge of contaminated liquid wastes, and was apparently the primary liquid waste disposal site for all C Reactor operations. The 116-C-2A pluto crib also received a high priority score from the Hazard Ranking System (HRS) evaluation of the Hanford Site (Stenner et al. 1988).

Figure 2-1 shows the approximate location of the waste units; information on the potential contaminants originating from these waste units is summarized on Table 2-1. The only $100-\mathrm{BC}-2$ facility on Figure $2-1$ that is considered unlikely to contain any potential wastes is the $1702-C$ badge house.

Table 2-2 summarizes the radionuclide concentrations and inventories estimated to be present at the 100-BC-2 waste units, based on previous sampling or evaluation. A primary reference for radiological characterization of the $100-\mathrm{BC}-2$ operable unit sources is a sampling study of the 100 Areas performed during 1975/76 by Dorian and Richards (1978), which has served as a reference document for the HRS evaluation of the Hanford Site (Stenner et al. 1988), the WIDS database (WHC 1991) maintained by WHC, and this work plan. It should be noted, however, that only concentrations and inventories of selected radionuclides were reported in the $1975 / 76$ study. In particular, ${ }^{63} \mathrm{Ni}$, which is generally present at activities on the same order of magnitude as ${ }^{60} \mathrm{Co}$, was reported for only some samples; technecium-99 (99 Tc), detected in 100-B/C Area groundwater wells, was not evaluated; and daughter product radionuclides of ${ }^{90} \mathrm{Sr}$ and ${ }^{137} \mathrm{Cs}$ were not included in summaries of total activity.

The preliminary contaminants of concern for the LFI at the $100-\mathrm{BC}-2$ operable unit are listed in Section 3.3.2.5.

\subsubsection{Soil}

Except for routine process effluents, most wastes generated during operation of the C Reactor were intentionally disposed of directly into $100-\mathrm{BC}-2$ and $100-\mathrm{BC}-1$ operable unit soils. In addition, the piping associated with the process effluent system is known to have leaked into the soils of the $100 \mathrm{~B} / \mathrm{C}$ Area.

3.1.2.1 Background Soil Quality. There are no background soil data available specifically for the 100-BC-2 operable unit. Surface soil samples are collected periodically at a number of locations to determine the extent of contamination both on and off the Hanford Site as part of the Hanford Environmental Monitoring Program (Jaquish and Bryce 1989). These samples are of limited utility because they do not provide subsurface soil data, are only analyzed for a limited range of radionuclides, and are purposely located in areas where radionuclide levels are most easily detected. Onsite samples are collected at locations adjacent to major operating facilities, whereas offsite samples are collected around the Hanford Site perimeter, generally in a downwind direction. Because of their intentional proximity to operating facilities, onsite samples may not be regarded as providing an adequate background concentration reference point. Data from both onsite and offsite 
samples collected in 1988 are presented in Table 3-5 of the 100-BC-1 work plan (DOE-RL 1992a). A background soil study was conducted in 1991 (Hoover and LeGore 1991) that analyzed soil samples for inorganic constituents. The results of that study are available in Table 3-1 of that report.

The composition of naturally occurring soils in the vadose zone of the Hanford Site has been determined for nonradioactive inorganic and organic analytes in accordance with EPA analysis methods. This work is in support of the Tri-Party Agreement Milestone M-28-00, which states "Submit all soils and groundwater background determination documents to EPA and Ecology."

As a result of the background samples analyzed, comparisons for the correlation coefficient (goodness of fit) and several percentiles $(80,90$, and 95 ), as well as the upper tolerance intervals associated with each percentile, have been formulated. The $95 \%$ upper threshold limit (UTL) for inorganic analytes from a lognormal distribution of the data is presented in Table 3-1.

3.1.2.2 Soil Contamination. No surface or subsurface soil sampling stations are located in the 100-B/C Area as pari of the Hanford Environmental Monitoring Program. The sampling and characterization at $100-\mathrm{BC}-2$ operable unit to date has been limited to radiological investigations by Dorian and Richards (1978) and no characterization of nonradioactive inorganic or organic species has been performed. Data from analogous facilities will also be assessed to aid in the characterization of the $100-\mathrm{BC}-2$ waste sites.

\subsection{POTENTIAL ARAR}

Remedial action at the 100 -BC-2 operable unit is generally required to comply with federal and state environmental laws and promulgated standards, requirements, criteria, and limitations that are applicable or relevant and appropriate under the circumstances presented by the release or threatened release of hazardous substances, pollutants, or contaminants. This is referred to as ARAR compliance.

Since the investigations described in this work plan are intended to aid in the definition of contaminant characteristics in the 100-BC-2 operable unit, the initial ARAR cover a wide scope and can, therefore, be referenced to Section 3.2 of the $100-\mathrm{BC}-1$ operable unit work plan (DOE-RL 1992a). The contaminant-specific requirements should address currently known or suspected contaminants that may be present in the $100-\mathrm{BC}-2$ operable unit. 


\subsection{POTENTIAL IMPACTS TO HUMAN HEALTH AND THE ENVIRONMENT}

This section provides a preliminary qualitative assessment of the impact of known contaminants on human health and the environment from the $100-\mathrm{BC}-2$ operable unit. This assessment is based on currently available information regarding the contamination exposure pathway model for the operable unit.

Due to the qualitative methodology and limited data on which this assessment is based, neither the structure nor conclusions of this section are intended to limit the focus of subsequent risk assessments. The conclusions in this section are tentative and will be subject to refinement based on the results of the RI. After the limited field investigations addressed in this work plan are complete, an LFI report will be drafted to summarize the results of the investigations and discuss the qualitative risk assessment performed based on the data gathered. A quantitative, baseline risk assessment will be conducted as described in Section 5.1.1.11 of the 100-BC-1 operable unit work plan based on the conclusions developed from the expedited response action (ERA), LFI, IRM, and RI paths.

\subsubsection{Conceptual Exposure Pathway Model}

Based on information presented thus far, a preliminary conceptual model of potentially significant contaminant exposure pathways for the $100-\mathrm{BC}-2$ operable unit was developed. This model, which focuses on the current understanding of the operable unit, is presented in Figures 3-1 and 3-2. The model also includes media (i.e., groundwater, surface water and sediments, and aquatic biota) that will be specifically investigated under the 100-BC-5 operable unit work plan.

The purpose of the conceptual model is to present hypotheses of operable unit-specific contaminant exposure pathways. During the RI, the conceptual model hypotheses will be tested and refined in an iterative manner until the understanding of the operable unit is sufficient to support subsequent decisions regarding remedial action. By conducting the RI in an iterative manner, the project becomes more efficient because the investigation remains in focus with operable unit-specific objectives.

Risk assessments and sensitivity analyses are two methods of testing and refining the conceptual model. Computer codes used in the risk assessment will be determined based on the site-specific modeling requirements identified during the RI. Computer codes for risk assessment are identified in Appendix B of Hanford Site Baseline Risk Assessment Methi."'ngy (DOE-RL 1993).

Each exposure pathway must contain the following for there to be a potential impact on human health or the environment:

- a contaminant source

- a contaminant release mechanism 
- an environmental transport medium

- an exposure route

- a receptor.

3.3.1.1 Sources. Primary contaminant sources at $100-\mathrm{BC}-2$ include process effluent transfer, treatment, and disposal facilities and contaminated reactor ancillary facilities. The significant sources appear to be the process effluent facilities, particularly the $116-\mathrm{C}-2$ pluto crib system.

Preliminary information on each of the operable unit waste facilities and their associated contaminants is presented in Section 2.1.3. Waste inventories have been estimated for some sources where data are available. A summary of the known extent of soil contamination at the 100-BC-2 operable unit is provided in Section 3.1.2. Groundwater, surface water, and river sediments are addressed in 100-BC-5 operable unit work plan (DOE-RL 1992b).

Other potential primary sources of contamination considered less significant, based on the current knowledge of the site, are the septic tanks and associated drain fields and radioactive and nonradioactive solid waste disposal sites. Information on non-radiological contamination at the operable unit is limited primarily to information on the chemicals used at the site and groundwater sampling data. PCB-containing electrical equipment and hydraulic machinery were used in the $100-\mathrm{B} / \mathrm{C}$ Area, and a solvent storage building has been noted in the review of building plans. These are considered at this time to be insignificant sources. There are no sampling or analytical data concerning organic wastes or contamination in the source areas or the vadose zone soils.

Soils at the 100-BC-2 operable unit may serve as secondary contaminant sources. Once a release to the environment occurs, contaminants can be bound in soils before being slowly re-released if there is sufficient infiltration of water. This medium is indicated in Figure 3-1 as a secondary contaminant source.

3.3.1.2 Release Mechanisms. Release mechanisms can be divided into primary and secondary categories. A primary release is one from the primary contaminant source, such as a from a crib to the soil; a secondary release is one that occurs, for example, from the contaminated soil to the groundwater.

Process effluents at the 100-BC-2 operable unit are known to have infiltrated the soils surrounding the various process effluent transfer, treatment, and disposal facilities. Effluent was directly discharged to the soil column at the 116-C-2 pluto crib system. Pipeline leaks occurred that resulted in discharges to surface soils. Wastes from the sanitary sewage systems also infiltrated into underlying and adjacent soils. As indicated in Figure 3-1, the most probable significant current primary release mechanism at the $100-\mathrm{BC}-2$ operable unit is considered to be infiltration, and the most substantial contributions are from process effluent wastes. Past significant primary release during $C$ Reactor operations also included direct discharge of process effluents to the Columbia River. 
The most significant release mechanism from the secondary soil sources is considered to be infiltration to groundwater. Fluctuation of groundwater levels, mostly by Columbia River influences, could also be a secondary release mechanism. Fugitive dust generation is a potential secondary release mechanism for surface contaminated soils; however, most contaminated soil areas have been adequately stabilized.

3.3.1.3 Environmental Transport Media. Contaminants in the soil column can infiltrate and eventually reach the groundwater, which, in turn, transports the material to the Columbia River. This is currently the predominant mode of contaminant transport at the $100-\mathrm{BC}-2$ operable unit. The river then transports contaminants that have been received through groundwater discharge, resulting in possible human and environmental receptors exposures distant from the 100-BC-2 operable unit. Contaminated fugitive dust may also be transported by wind. Contaminated biota could be a secondary transport medium through ingestion by herbivores.

\subsubsection{Exposure Routes. Receptors can be exposed to contaminants in several ways:}

- through inhalation of contaminants in the ambient atmosphere

- through uptake of soil contaminants (for plants) or the ingestion of contaminated materials and biota (for animals and humans)

- through dermal contact with contaminated sources or media, external exposure to gamma radiation emitted by certain radionuclides.

3.3.1.5 Receptors. Receptors are organisms that have the potential for exposure to the released contaminants.

Because there are no nearby residences, the potential human exposure to the $100-B C-2$ operable unit contaminants would primarily be limited to onsite workers. Because most of the contamination is buried beneath the ground surface, the workers who could have the greatest potential exposure are those who will be involved in collecting environmental samples for this project. There may also be a potential for offsite human exposure through consumption of contaminated fish and game.

The most likely point of exposure for terrestrial biota is in the plant root zone, where flora could absorb contaminants from the soil. Terrestrial animals (especially burrowing animals) may be exposed by direct soil contact and by consumption of contaminated flora. The probable exposure point in the aquatic environment is discussed in the 100-BC-5 operable unit work plan.

3.3.1.6 Summary. Preliminary evaluation suggests that the most probable primary sources of contaminant releases to the $100-\mathrm{BC}-2$ operable unit environment are the process effluent disposal facilities. Although some process effluents from the $100-\mathrm{B} / \mathrm{C}$ Area were discharged directly into the Columbia River, the highly contaminated effluent discharge to the 116-C-2 pluto crib system was disposed directly into the soil column. The current mechanism of contaminant release is through infiltration into the underlying groundwater from contaminated 
soils near the 100-BC-2 operable unit facilities. This groundwater eventually discharges into the river, where it can contaminate the sediments and has the potential to impose adverse impacts upon local biota, with possible food-chain effects on humans offsite. The conceptual exposure pathway model will be tested and refined during the RI as additional data provide a better understanding of the operable unit.

\subsubsection{Preliminary Identification of Contaminants of Concern}

With the variety of waste types known to have been used and disposed of in the $100-\mathrm{BC}-2$ operable unit, it becomes necessary to focus on those that pose a potential threat to human health or the environment. The focus will be on those contaminants that are characterized by the following:

- present in the greatest quantity

- most hazardous

- most persistent in the environment

- found at elevated levels in the environment.

Each of these factors is discussed in the following sections. The information provided will be used to preliminarily identify operable unit contaminants of concern.

3.3.2.1 Quantity. One means to focus on those contaminants of greatest concern is to identify those contaminants that are potentially present in the greatest quantity. It should be noted that most of the quantities of waste disposed of are unknown and that waste inventories are not available for many of the compounds that may have been disposed within the 100-BC-2 operable unit. No disposal data are presently available for any organic compounds that may have been used at this site.

3.3.2.2 Hazard. The hazard of a contaminant is generally associated with toxicity. The definition of hazardous is basically waste that may cause or significantly contribute to an increase in mortality or an increase in serious irreversible, or incapacitating reversible illness; or pose a substantial present or potential hazard to human health or the environment.

The primary constituents that would be present following the dissociation of acids or soluble salts include sodium, sulfate, fluoride, and chloride ions and chromium (VI). Sodium and chloride ions are considered essentially nontoxic to humans under most environmental conditions, but may influence the salinity of groundwater or surface water. Sulfate toxicity is minimal and ingestion is commonly associated with mild gastrointestinal effects. Fluoride may have beneficial effects at low levels but higher levels are associated with toxic human effects. 
Chromium (VI) exhibits significant environmental or human toxicity that will be considered in the baseline risk assessment. Chromium (VI) is classified as an EPA Class A human carcinogen by the inhalation route; however, there is no evidence that chromium (VI) is carcinogenic from oral exposure (EPA 1991). Systemic toxic effects include respiratory irritation and allergic reactions (EPA 1986a). Chromium (III) can also exhibit toxic effects although not as severe as chromium (VI). Chromium (VI) is toxic to aquatic organisms. Ambient water quality criteria for the protection of freshwater organisms are: acute, $16.0 \mu \mathrm{g} / \mathrm{L}$, and chronic, $11.0 \mu \mathrm{g} / \mathrm{L}$ (EPA 1986a).

Cadmium may also exhibit significant environmental or human toxicity. Cadmium accumulates in the kidney tissue and contributes to progressive renal damage that may result in renal failure. Occupational inhalation exposures to cadmium have been associated with lung damage and possibly lung and prostate cancer. Cadmium is classified as EPA Class B1 carcinogen by the inhalation route (EPA 1991). Ambient water quality criteria are dependent on water hardness (EPA 1986a).

Lead is a cumulative toxin producing symptoms that range from mild blood enzyme changes to severe neurological disease. Effects from lead exposures may be so subtle as to be without a threshold, and the EPA currently does not recommend quantitative evaluation of health affects associated with the lead exposures (EPA 1991). Lead is classified as an EPA Class B2 carcinogen (EPA 1991). Ingestion is a primary route of exposure. Ambient water quality criteria for lead are dependent on water hardness (EPA 1986a).

Toxicity associated with mercury is highly dependent on the chemical form (inorganic, organic, elemental) and the route of exposure. Toxic effects include central nervous system damage with chronic exposure to inorganic mercury; exposure to organic mercury compounds can produce kidney disease, central nervous system effects, and birth defects. Inorganic forms of mercury can be methylated in sediments, in fish, and in the food chain for fish. Ambient water quality criteria for the protection of freshwater organisms are: acute, $2.4 \mu \mathrm{g} / \mathrm{L}$, and chronic, $0.12 \mu \mathrm{g} / \mathrm{L}$.

PCB are of environmental and human concern because they are persistent and bioaccumulate. The primary toxicity associated with human occupational exposures to PCB is chloracne. Animal studies suggest PCB may cause liver damage, liver cancer, and reproductive effects; however, these effects have not been confirmed in humans. PCB are classified as an EPA Class B2 carcinogen (EPA 1991). A 24-hr average freshwater quality criterion for $\mathrm{PCB}$ of $0.014 \mu \mathrm{g} / \mathrm{L}$ is considered protective for both acute and chronic toxicity (EPA 1986a).

Asbestos, known to be present in operable unit buildings, is a known human carcinogen. Exposures to asbestos are associated with chronic lung disease (asbestosis), lung cancer, and mesothelioma (a rare and rapid fatal cancer). Asbestos is classified as an EPA Class A human carcinogen (EPA 1991). 
Nitrate is a decomposition product of nitric acid. This inorganic ion is of concern primarily because of possible human health effects. High levels in drinking water can produce problems in the oxygen transport system of the blood. Infants are particularly sensitive to this toxic effect.

The potential exposure to any of the radionuclides is toxicologically significant. The dose response functions used by EPA to estimate radiation risks (linear and linear quadratic) presume that any radionuclide exposure carries with it some associated excess cancer risk. Consequently, based on conservative assumptions, the presence of and potential exposure to any nuclide or ruclides at greater than background concentrations is presumed to introduce some excess cancer risk that must be evaluated. In light of the additive effects of the various radionuclides, all of the isotopes of concern identified during RI activities must be considered in the baseline assessment of cancer risk.

3.3.2.3 Persistence. The compounds present include corrosives, radionuclides, metals, and other persistent compounds. Corrosive acids, bases, and salts such as nitric acid, sodium hydroxide, and sodium fluoride, do not persist in the environment in their original form because they rapidly dissociate into their constituent ions once they come in contact with water. The constituent ions may pose less of an immediate environmental and toxicological concern than the parent compound; however, the ions may persist and accumulate with time in the environment, producing concern over long-term effects. For example, gradual increases in nitrate in surface waters and groundwater are linked to human health effects and environmental effects such as eutrophication of lakes. Metals such as chromium are also persistent in the environment and may pose an environmental and toxicological concern because of this persistence.

The environmental persistence of a radionuclide is in part directly related to the halflife of the particular isotope.

3.3.2.4 Environmental Occurrence. The environmental occurrence of contaminants at the $100-\mathrm{BC}-2$ operable unit can be determined empirically through the evaluation of existing $100-\mathrm{B} / \mathrm{C}$ groundwater data. Groundwater in and adjacent to the 100 Areas is contaminated with ${ }^{3} \mathrm{H}$, nitrate, ${ }^{90} \mathrm{Sr}$, and chromium (VI). Chromium (IV) contamination resulted from widespread use of sodium dichromate and chromic acid. One potential source of nitrate is nitric acid. Although other contaminants have been identified in the groundwater within the $100-\mathrm{B} / \mathrm{C}$-Area, it is not currently possible to assign any of these contaminants to specific $100-\mathrm{BC}-2$ operable unit sources. The radiological sampling efforts undertaken in conjunction with decommissioning activities have identified the radionuclides known to be present at the $100-B C-2$ operable unit. Radionuclides have also been detected in the groundwater. At this time, there are no data concerning the environmental occurrence of organic contaminants at the $100-B C-2$ operable unit. 
3.3.2.5 Summary of Preliminary Contaminants of Concern. The following is a list of preliminary contaminants of concern for the $100-\mathrm{BC}-2$ operable unit:

Metals
$\begin{aligned} & \text { cadmium } \\ & \text { chromium } \\ & \text { lead } \\ & \text { mercury }\end{aligned}$
Nonmetallic Ions
nitrate
nitrite
sulfate
Other

PCB
Radionuclides .

hydrogen-3

carbon-14

cobalt- 60

nickel-63

strontium-90

technetium-99

ruthenium-106

iodine-129

cesium-137

europium-152, $-154,-155$

uranium-235, -238

plutonium-238, $-239,-240,-241$

americium-241

asbestos

This list was developed based on the types and quantities of wastes currently known to have been disposed of or to have been derived from a constituent known to have been disposed of at the 100-BC-2 operable unit, and the contaminant characteristics presented in Section 3.3.2. The list contains metals, nonmetallic ions, and radionuclides; it does not include organic compounds, with the exception of PCB. Organic compounds have not been included because data are currently unavailable on the types, locations, and quantities of organic compounds that may have been disposed of at the 100-BC-2 operable unit. Additional contaminants of concern may be identified when the nature of contamination is identified during the limited field sampling performed during the LFI.

\subsubsection{Assessment of Need for ERA}

During work plan scoping where the known characteristics of each waste site were discussed, the three parties did not identify any situations at the 100-BC-2 operable unit that warrant response through an ERA. The basis for this conclusion is discussed below. Factors to be considered for conducting removal actions under CERCLA, 40 CFR Part 300.415 (b) include affects upon human health and the environment. The purpose of an ERA is to mitigate threats to human health and the environment.

3.3.3.1 Human Health. Based on the existing environmental data and the exposure pathways discussed in Section 3.3.1, the 100-BC-2 operable unit does not appear at this time to pose any immediate endangerment to human health. 
The major health concern associated with the $100-\mathrm{BC}-2$ operable unit is exposure to onsite workers during the implementation of the RI field investigations. The Health and Safety Plan (Appendix B) specifies site control and personnel monitoring procedures that will ensure the health and safety of those involved with the field portions of the project.

3.3.3.2 Environment. Existing information and ongoing Hanford Site monitoring, as well as site access restrictions, indicate that immediate endangerment to the environment does not exist within the $100-\mathrm{BC}-2$ operable unit. If any evidence of endangerment is found during the course of the RI/FS, a removal site evaluation may be necessary in accordance with 40 CFR 300.410.

\subsection{PRELIMINARY REMEDIAL ACTION OBJECTIVES AND ALTERNATIVES}

The preliminary discussion of objectives and alternatives can be referenced in the 100-BC-1 operable unit work plan since the considerations are of a general nature. The remedial action objectives may change or be refined as additional data are gathered and evaluated during the LFI. The remedial action alternatives will be more fully developed and evaluated in the focused FS when additional and more specific information becomes available from the LFI. Figure 3-3 is a matrix of preliminary interim response actions, technologies, and process options available. 
DOE/RL-91-07, Rev. 0

Figure 3-1. Conceptual Model Exposure Pathways - Process Effluents.
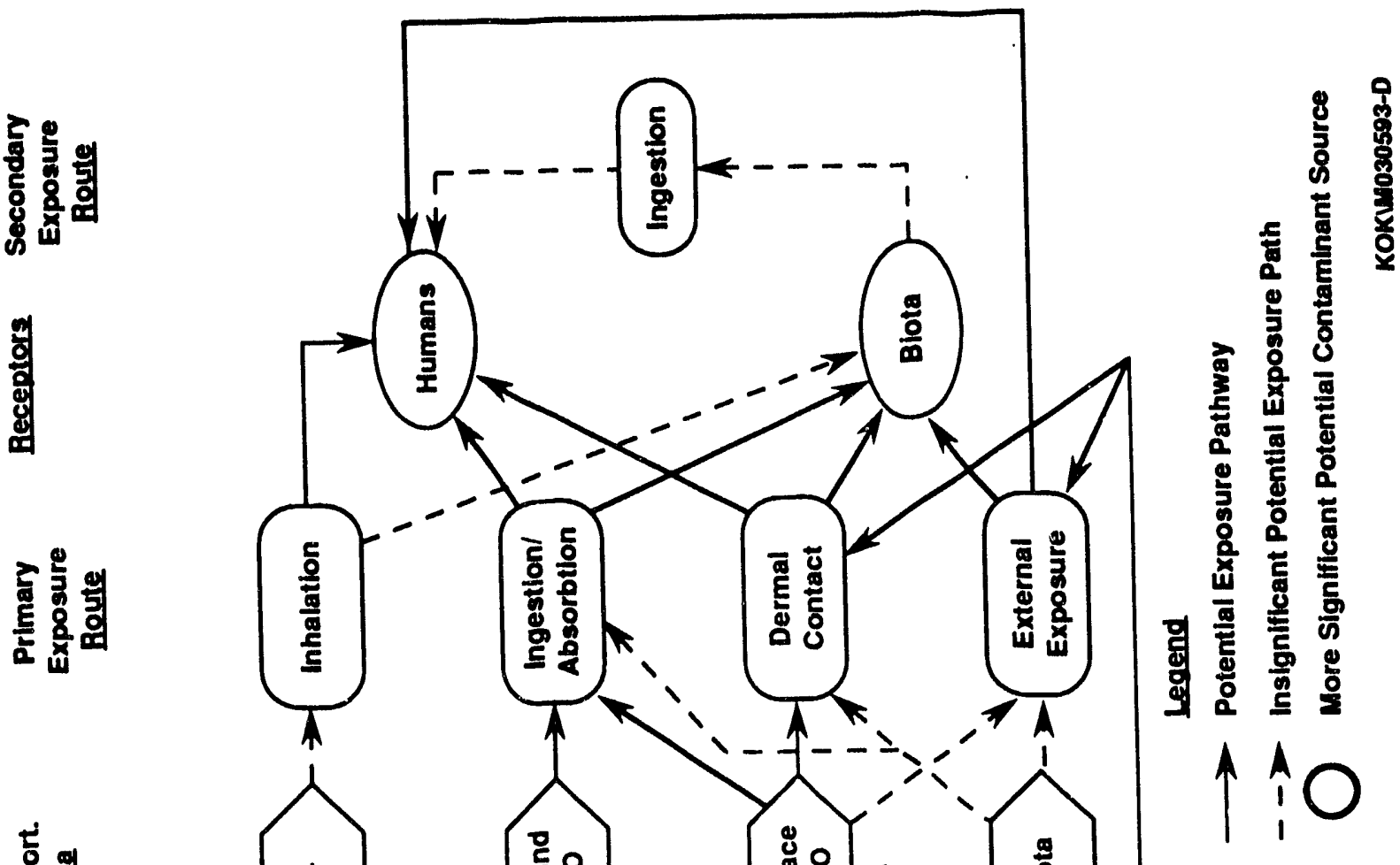

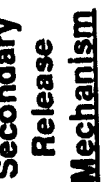

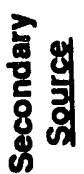

高현

C

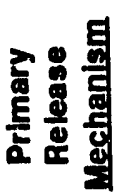

홀

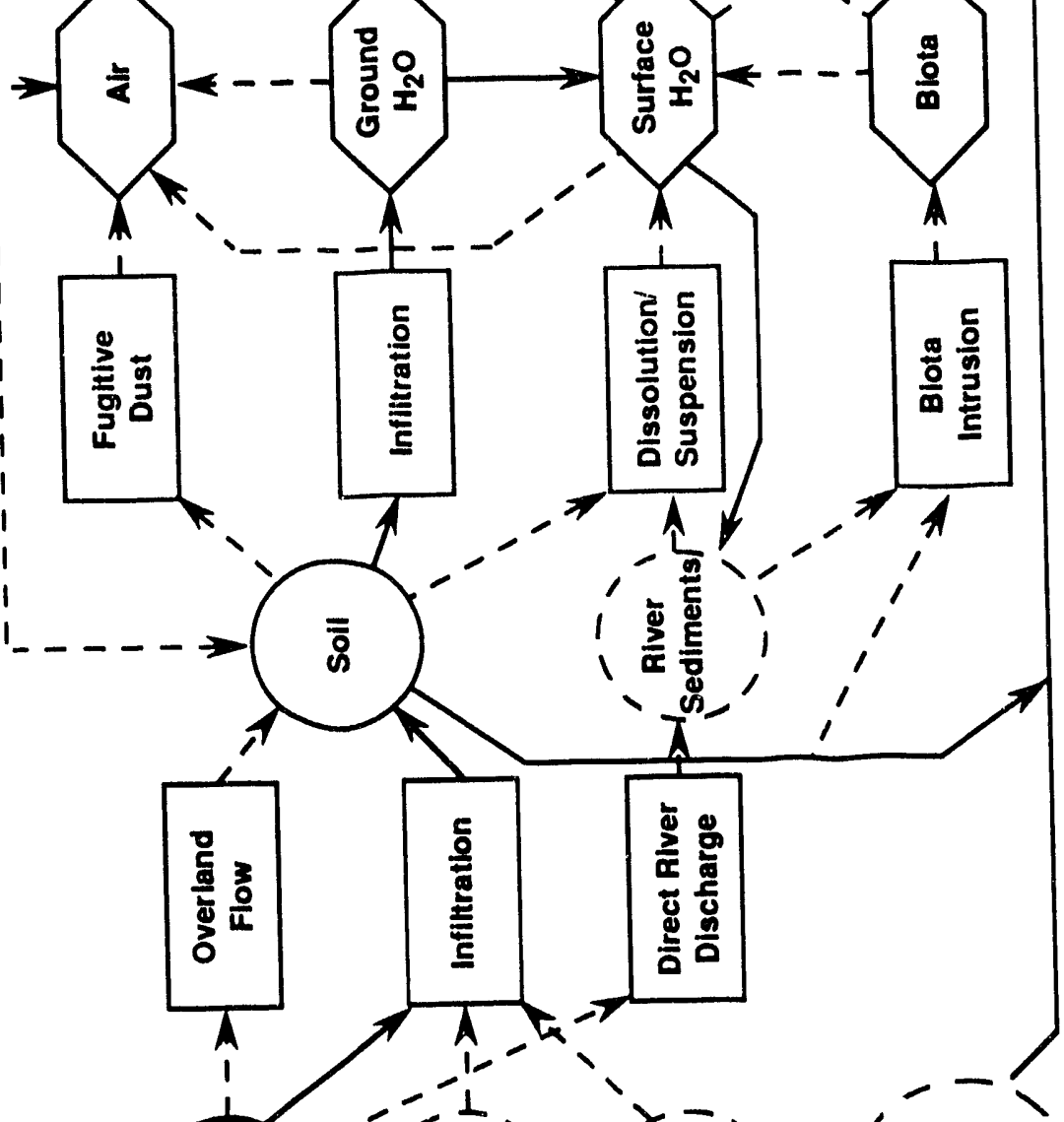

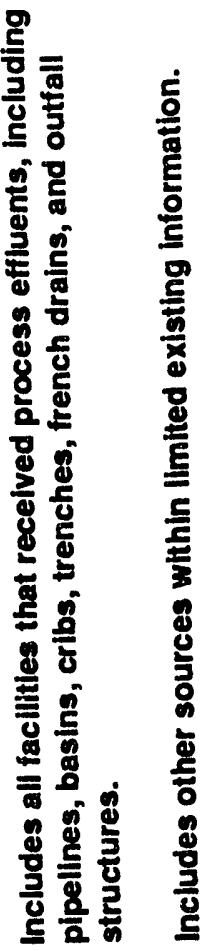

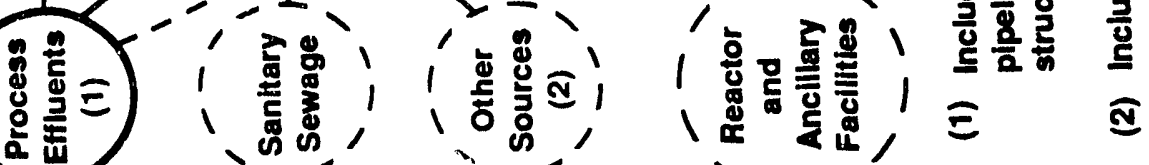


DOE/RL-91-07, Rev. 0

Figure 3-2. Conceptual Model Exposure Pathways - Burial Grounds.

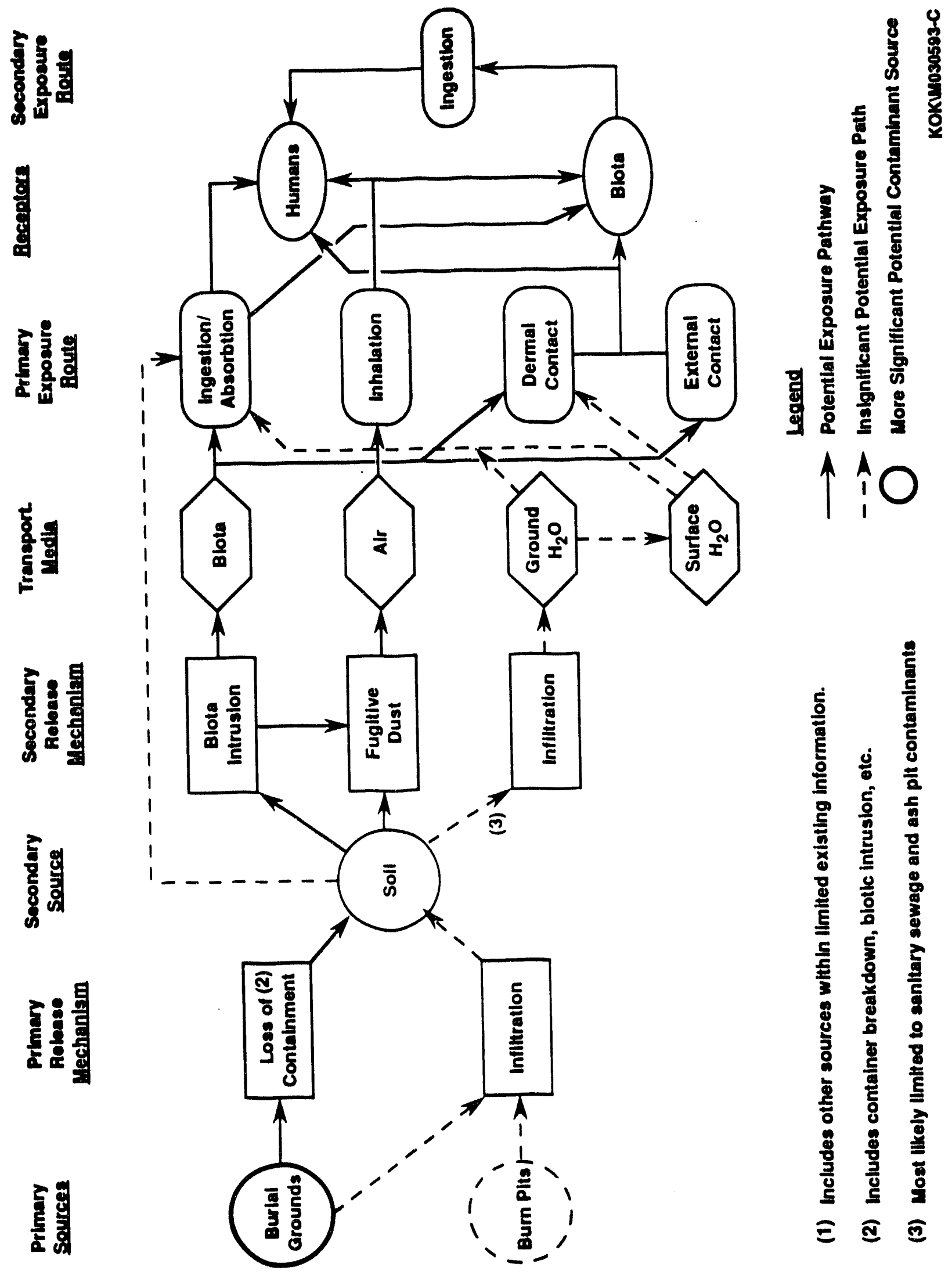


Figure 3-3. Matrix of Preliminary Interim Response Actions, Technologies, and Process Options.

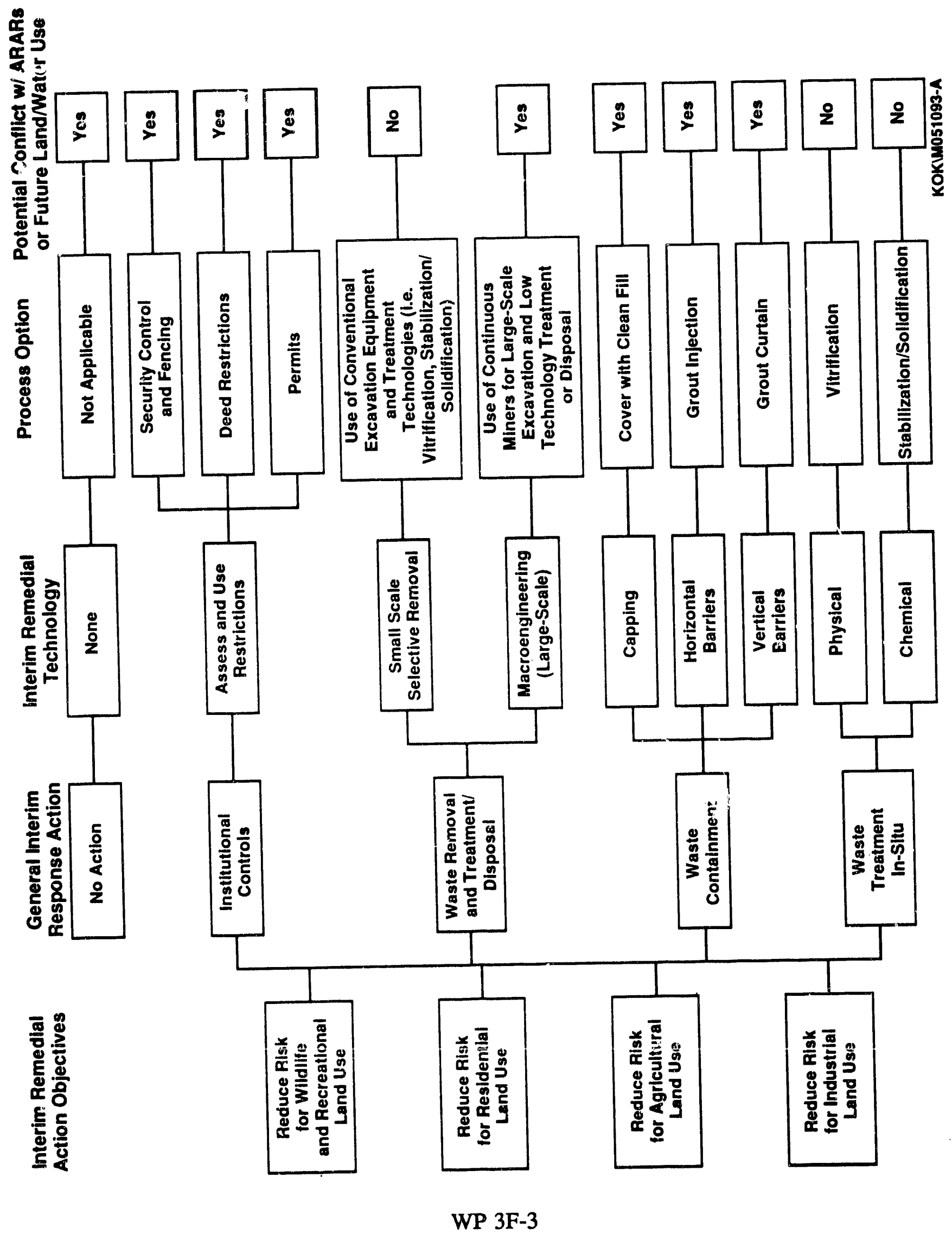


Table 3-1. Hanford Site Background Summary Statistics and Upper Threshold Limits (UTL) for Inorganic Analytes.

\begin{tabular}{|c|c|c|c|c|c|}
\hline Analyte & $\begin{array}{l}95 \% \text { Dist } \\
(\mathrm{mk} / \mathrm{kg})\end{array}$ & $\begin{array}{c}95 \% U_{T} \mathrm{~b} \\
(\mathrm{mk} / \mathrm{kg})\end{array}$ & Analyte & $\begin{array}{c}95 \% \text { Dist" } \\
(\mathrm{mk} / \mathrm{kg})\end{array}$ & $\begin{array}{l}95 \% \mathrm{UTL}^{\mathrm{b}} \\
(\mathrm{mk} / \mathrm{kg})\end{array}$ \\
\hline $\begin{array}{l}\text { Aluminum } \\
\text { Antimony } \\
\text { Arsenic } \\
\text { Barium } \\
\text { Beryllium } \\
\text { Cadmium }\end{array}$ & $\begin{array}{l}13,800 \\
\text { NR* }^{*} \\
7.59 \\
153 \\
1.62 \\
\text { NR }\end{array}$ & $\begin{array}{c}15,600 \\
15.7^{\mathrm{c}} \\
8.92 \\
171 \\
1.77 \\
0.66^{\mathrm{c}}\end{array}$ & $\begin{array}{l}\text { Silver } \\
\text { Sodium } \\
\text { Thallium } \\
\text { Vanadium } \\
\text { Zinc } \\
\text { Molybdenum }\end{array}$ & $\begin{array}{c}1.4 \\
963 \\
\text { NR } \\
98.2 \\
73.3 \\
\text { NR }\end{array}$ & $\begin{array}{c}2.7 \\
1,290 \\
3.7^{\mathrm{c}} \\
111 \\
79 \\
1.4^{\mathrm{c}}\end{array}$ \\
\hline $\begin{array}{l}\text { Calcium } \\
\text { Chromium } \\
\text { Cobalt } \\
\text { Copper } \\
\text { Iron } \\
\text { Lead }\end{array}$ & $\begin{array}{c}20,410 \\
23.4 \\
17.9 \\
25.3 \\
36,000 \\
12.46\end{array}$ & $\begin{array}{c}23,920 \\
27.9 \\
19.6 \\
28.2 \\
39,160 \\
14.75\end{array}$ & $\begin{array}{l}\text { Titanium } \\
\text { Zirconium } \\
\text { Lithium } \\
\text { Ammonia } \\
\text { Alkalinity } \\
\text { Silicon }\end{array}$ & $\begin{array}{c}3,020 \\
47.3 \\
35 \\
15.3 \\
13,400 \\
108\end{array}$ & $\begin{array}{c}3,570 \\
57.3 \\
37.1 \\
28.2 \\
23,300 \\
192\end{array}$ \\
\hline $\begin{array}{l}\text { Magnesium } \\
\text { Manganese } \\
\text { Mercury } \\
\text { Nickel } \\
\text { Potassium } \\
\text { Selenium }\end{array}$ & $\begin{array}{c}7,970 \\
562 \\
0.614 \\
22.4 \\
2,660 \\
\text { NR }\end{array}$ & $\begin{array}{c}8,760 \\
612 \\
1.25 \\
25.3 \\
3,120 \\
5^{\mathrm{c}}\end{array}$ & $\begin{array}{l}\text { Fluoride } \\
\text { Chloride } \\
\text { Nitrite } \\
\text { Nitrate } \\
\text { Ortho- } \\
\text { phosphate } \\
\text { Sulfate }\end{array}$ & $\begin{array}{c}6.4 \\
303 \\
\text { NR } \\
96.4 \\
3.7 \\
\\
\\
580\end{array}$ & $\begin{array}{c}12 \\
763 \\
21^{\mathrm{c}} \\
199 \\
16 \\
\\
1,320\end{array}$ \\
\hline
\end{tabular}

NOTES:

$*$ = Not reported.

" = 95th percentile of the data for a lognormal distribution.

$b=95 \%$ confidence limit of the 95 th percentile of the data distribution.

$c=$ Limit of detection. 


\subsection{RATIONALE AND APPROACH}

The rationale for conducting the RI is established by identifying data quality objectives (DQO) and specific data needs. These are based, in part, on the Hanford Site Past-Practice Strategy (DOE-RL 1991a). This strategy and the scoping efforts of the EPA, DOE, and Ecology emphasize a bias for action, by quickly and efficiently implementing ERAs and IRMs, to achieve cleanup actions at high-priority areas of contamination. During the scoping efforts, the three parties have not identified any candidate sites within the 100-BC-2 operable unit for conducting an ERA. Several sites (Table 4-1) have been identified as potential candidates for conducting IRM. The three parties also recognize the need to more closely integrate source and groundwater operable unit investigations and remediation, and acknowledge that some environmental media should be investigated on an aggregate-area basis. Table 4-2 summarizes how investigations from source and groundwater operable units as well as aggregate-area studies satisfy the data needs for the $100-\mathrm{BC}-2$ operable unit.

To implement this strategy, data are needed for specific waste sources, groundwater contaminant plumes, and contamination of other environmental media to refine existing conceptual models and to conduct a qualitative risk assessment. The data must be adequate to determine whether concentrations of contaminants pose an unacceptable risk that should be remediated through an ERA or IRM. Data are also needed to complete a quantitative baseline risk assessment and select a final remedy for the overall operable unit and for the 100 Area NPL site. Section 4.1 of the 100 -BC-1 operable unit work plan describes the general DQO process, and should be referenced for that discussion as it is not specific to the 100-BC-2 operable unit. A site-specific discussion of DQO and data needs related to the $100-\mathrm{BC}-2$ investigations is given below.

\subsection{DQO PROCESS}

The central rationale for undertaking a remedial investigation at the $100-\mathrm{BC}-2$ operable unit is to develop needed data that are lacking in the available information. The amount and quality of available information are not adequate to quantify the risk posed by the operable unit and to complete the FS.

The rationale for the technical approach presented in this RI/FS work plan is based on two concepts. First, every activity and effort of the RI field program shall be justified by producing data for one or more of the following project purposes:

- Confirm or revise the conceptual models for specific waste sites/areas of contaminated environmental media for the operable unit and aggregate area.

- Support a qualitative risk assessment. 
- Support development and evaluation of interim remedial measures for individual waste sites, groups of sites or areas of environmental contamination.

- Support the quantitative baseline risk assessment for the operable unit.

- Support the ARAR evaluation.

- Support the development, evaluation, and selection of a final remedial alternative.

Second, a streamlined approach with a bias for action will be followed through the use of LFI. This approach will focus on obtaining data sufficient to implement IRM and will use the observational approach during implementation of the remedy to reduce the amount of data required to initiate cleanup. The emphasis in this work plan is on describing those data that will be obtained at high-priority areas of contamination to determine whether to implement IRM. However, general data needs for the quantitative risk assessment and final remedy selection are also addressed. Other secondary data uses include health and safety planning and environmental monitoring during the implementation of a remedial action.

The methods used to identify data uses and needs can be referenced to Section 4.1.1 of the 100-BC-1 operable unit work plan (DOE-RL 1992a) or Data Quality Objectives For Remedial Response Activities (CDM Federal Programs Corporation 1987). The three elements of the DQO process are: (1) the identification of data users, (2) identification of data uses and needs, and (3) data collection program design.

\subsubsection{Data Users}

The primary data users will be the decision makers identified in the Tri-Party Agreement. These are the DOE, the EPA, and Ecology. Additional primary data users will be any technical lead organization responsible for the RI/FS tasks as directed by DOE, EPA, and Ecology. Secondary data users include the support groups within the technical lead organization who may utilize the data for activities not necessarily associated with this investigation (i.e., Geosciences for site-wide modeling). Other potential data users include technical support groups who provide input through the review process described in Environmental Investigation Instruction 1.9 of the Environmental Investigations and Site Characterization Manual (WHC 1988).

\subsubsection{Identification of Data Uses and Needs}

The second element of the DQO process is the identification of data uses and needs. The determination of data uses and needs is supported by evaluation of available data and development of an operable unit conceptual model. These are presented in Chapters 2 and 3 of this work plan. The data that have been reviewed are the basis for prioritizing sites for conducting an LFI, which may lead to IRM. Historical data were discussed at scoping 
meetings with the DOE, EPA, and Ecology to develop the final strategy for each site. The information has also been used to help determine what additional data must be obtained.

The data types needed to support the decision making process are outlined below:

- Location, disposal history, and construction of all identified and newly discovered contaminant sources

- Quantity, nature, and extent of contamination in surface soils, the vadose zone and aquifer matrix, especially from disposal of radioactive and nonradioactive liquid wastes in the cribs and trenches

- Geochemical, geologic, and physical characteristics of the vadose zone, especially in relation to the fate and transport of contaminants from waste sites to the groundwater and also to support the evaluation of remedial action alternatives

- Information on the nature and extent of contamination in the terrestrial, riparian and aquatic biota adjacent to and in the vicinity of the 100-B/C Area

- Information on the potential for airborne contamination from fugitive dust.

Table 4-2 is a summary of the data needs for the 100-BC-2 operable unit. If additional data are needed at the completion of the LFI to evaluate interim remedial measures, additional data may be collected as part of the focused FS.

The quality of the data needed is defined by sampling and analysis protocols outlined in the QAPjP (Appendix A). The quantity of data needed is difficult to define at the LFI stage. The goal is to obtain sufficient data to identify the nature and vertical extent of contamination. The final quantity of data obtained will be dependent on information from analogous facilities, and by employing the observational approach in the investigations. The specific analytical requirements related to precision and accuracy parameters are detailed in Appendix A (Table QAPjP-1).

The DQO specific to the LFI program for $100-\mathrm{BC}-2$ are shown on Tables 4-3 and 4-4. These data types were developed from the list of contaminants of interest for the 116-C-2-A pluto crib and the 116-C-2-C pluto crib sand filter discussed in section 2.1.3.1.2. The minimum analytical detection limits were selected as one-tenth of the $10^{-6}$ risk-based exposure level for ingestion of the particular contaminant. The $10^{-6}$ risk-based exposure level was calculated using the Hanford Site Baseline Risk Assessment Methodology (DOE-RL 1993b). 
A $10^{-6}$ risk-based exposure level for lead cannot be calculated as no reference dose or slope factor is available from the EPA Health Effects Assessment Summary Tables (EPA 1992). Therefore, the specified level of concern for lead on Tables 4-3 and 4-4 are assigned the $95 \%$ upper threshold limit value for Hanford Site background soils (Table 3-1).

In addition to the data types shown on Tables 4-3 and 4-4, geologic descriptions, soil types, and contamination physical position are necessary to support the data uses. This information is obtained through standard geologic description methods described in the QAPjP.

Precision and accuracy results from the laboratory will be compared with those identified for the particular analytical method employed. Sampling representativeness is controlled by the sampling program employed for the particular site. At the 100-BC-2 limited field sampling sites, samples will be selected for analysis through screening, with a bias for sending contaminated samples to the laboratory for analysis. The target for completeness for the Level III analyses is set for $70 \%$ of the requested analytes for each sample submitted. Comparability will be judged by whether or not the precision and accuracy goals are met and how well the data collected from the limited field sampling compares with historical data from the same horizon.

\subsubsection{Design of Data Collection Program}

The final element of the DQO process consists of the design of a data collection program. The associated QAPjP provides the mechanism by which the data collection program is implemented, controlled, and documented.

\subsection{INVESTIGATION STRATEGY}

The overall approach to the $100-\mathrm{BC}-2$ operable unit investigation is based on the Hanford Site Past-Practice Strategy (DOE-RL 1991a) and is described in Chapter 1 of the 100-BC-1 operable unit work plan (DOR-RL 1992b). In particular, this strategy recognizes that to expedite the ultimate goal of cleanup, much more emphasis needs to be placed on initiating and completing waste site cleanup through interim measures.

\subsubsection{Hanford Site Past-Practice Strategy}

The 100-BC-1 operable unit work plan can be referenced for the specifics of the Hanford Site past-practice strategy. The strategy for the 100 Area source operable units focuses on two preferred decision-making paths that will lead to IRM:

- Limited field sampling will be performed at high priority waste sites where existing data are considered insufficient to make decisions for conducting IRM. 
- IRM have been determined appropriate along the IRM path, without additional field investigations, at waste sites where existing data are considered sufficient to indicate that the site poses a risk through one or more pathways, based on information in existing work plans and the collective knowledge of the three parties.

\subsubsection{Investigation Strategy for 100-BC-2 Operable Unit}

This work plan describes the approach for implementing the past-practice strategy for currently identified high-priority contaminant sources at the $100-\mathrm{BC}-2$ operable unit. Sites that are in close proximity to the reactor building will be deferred to the decommissioning program. However, if the decommissioning program is not completed within a time frame compatible with the past-practice strategy, these facilities will be incorporated into this program prior to issuing the $100 \mathrm{NPL}$ record of decision. Investigations at low-priority sites will be deferred for long-term action for the final remedy selection process (see Figure 4-1), as deemed necessary. Solid waste burial grounds will follow the IRM pathway employing the analogous facility and observational approaches.

Table 4-1 lists the 100-BC-2 operable unit high- and low-priority sites as well as solid waste burial grounds to be addressed. The table also describes, in general terms, the number and location of boreholes where limited intrusive field investigations are to be performed to define the nature and vertical extent of contamination. It lists those sites where the DOE, EPA, and Ecology have determined that data are sufficient to determine that IRM are appropriate without further field investigations and also those sites that will be addressed at a later stage in the RI/FS process. Table 4-5 lists sites in the 100-BC-2 operable unit that have analogous facilities in the 100 Areas. This matrix will help identify sites that may have applicable data available or that could utilize data from the $100-\mathrm{BC}-2$ investigations.

Options for contingencies have also been developed as part of the past-practice strategy, which include the option for:

- Performing treatability studies or technology demonstrations at selected sites and using data from analog 100-BC-2 operable unit or 100 Area sites (The decision as to which waste sites will ultimately be selected as candidates for these studies must be agreed on at future unit managers' meetings.)

- Collecting additional data curing a focused feasibility study

- Deferring a waste site to the final remedy selection process.

4.2.2.1 Investigations at High-Priority Liquid Waste Sites. Based on operation, disposal history, and estimated inventory, the high priority liquid waste disposal site within $100-\mathrm{BC}-2$ operable unit is the $116-\mathrm{C}-2$ pluto crib system. 
LFI leading to IRM, as shown in a logic diagram in Figure 4-2, are proposed at highpriority liquid waste disposal sites. The sites included as high-priority at the 100-BC-2 operable unit are: (1) 116-C-2A pluto crib; (2) 116-C-2B pump station; and (3) 116-C-2C sand filter.

Boreholes will be placed in or adjacent to the 116-C-2A and 116-C-2C sites. The 116-C-2B pump station will be addressed later as an analogous site to the other two.

The knowledge gained from the sampling, characterization, and remediation of other 100-Area liquid waste units will be applied toward the remediation of the remaining liquid waste sites.

4.2.2.2 Investigations at Low-Priority Sites. Any field investigations at low-priority sites will be deferred until the final remedy selection phase for the operable unit (see Figure 4-1). Under the past-practice strategy, preliminary investigations will be limited to the evaluation of existing data. The following types of facilities have been deferred: septic systems, miscellaneous low-priority facilities, electrical facilities, support facilities where waste is currently known or suspected, and support facilities where no waste is suspected.

Prior to conducting any additional sampling at low-priority facilities, knowledge gained from the sampling, characterization, and remediation at other 100 Area low-priority facilities will be evaluated (see Figure 4-3). The following septic tanks and drain fields in the 100-BC-2 operable unit are identified as low priority: (1) 1607-B8; (2) 1607-B9; (3) 1607-B10; and (4) 1607-B11. Other low priority facilities are the 116-C-6 pond and the 116-C-3 storage tanks.

4.2.2.3 Investigations at Solid Waste Burial Grounds. Solid waste burial grounds are addressed through the IRM pathway (see Figure 4-1). The analogous facility approach will be used for initial evaluation of the burial grounds and the observational approach will be used during remediation. The following is a list of the solid waste burial grounds identified in the $100-\mathrm{BC}-2$ operable unit.

- 118-C-2, Ball 3X storage tank

- 118-C-4, horizontal control rod storage cave

- $\quad 118-\mathrm{B}-1$, burial ground

- $\quad 118-\mathrm{B}-2$, burial ground

- $\quad 118-\mathrm{B}-3$, burial ground

- $\quad 118-B-4$, burial ground

- $\quad 118-\mathrm{B}-6$, burial ground

- $\quad 118-\mathrm{C}-1$, burial ground

- $\quad 128-\mathrm{C}-1$, burning pit. 
An engineering study at the $118-\mathrm{B}-1$ and $118-\mathrm{C}-1$ burial grounds is being proposed through the Large Scale Remediation Program that will generate data on the solid waste burial grounds. This investigation will employ test pits to gather information to aid in the design of equipment and procedures necessary to facilitate large scale remediation at the 100-B/C Area.

The work associated with this study is related to subsequent remedial design activities that follow the RI/FS activities and is not within the scope of this work plan. The results of the investigation will aid in the design of the Large Scale Remediation Program for addressing similar burial grounds in other 100 Area operable units.

4.2.2.4 Investigations at Demolished and Decommissioned Facilities. Data will be reviewed at facilities already demolished by the decommissioning program to determine if further investigation is needed, as shown in a logic diagram in Figure 4-4. Currently, there are no demolished and decommissioned facilities identified which warrant investigation during the LFI.

\subsubsection{0-BC-2 Operable Unit Sampling and Analysis}

A primary assumption made based on previously approved source operable unit work plans was that investigations can be limited in scope by employing the observational approach during implementation of interim actions. The agreed to approach is based on the premise that limited data on the nature and vertical extent of contamination is needed for priority source areas. The DOE, EPA, and Ecology agree that, for most sites, one borehole, at a location likely to represent "worst case" conditions, is sufficient to determine the nature and vertical extent of contamination. These investigations, including the number and locations of boreholes, were identified in Section 4.2.2. Lateral extent of contamination and complete characterization is not required, since these data can be obtained as needed during the focused FS or during implementation of the IRM.

4.2.3.1 Source Sampling and Analysis. Depth of vadose zone borings will be based on field screening results where screening techniques are available for the contaminants expected to be present (i.e., radioactive and volatile organic contaminants).

Analysis will be conducted for the constituents listed in Tables 4-3 and 4-4. Chemical analysis will be conducted using EPA (Level III) methods (EPA 1986b). Standard methods will be used for radionuclide analysis. Routine analytical detection, quantitation limits, precision, and accuracy are specified in Appendix A (Table QAPjP-1).

4.2.3.2 Data Validation Requirements. Because the LFI data will be used to support and confirm existing information, validation will not be required for the LFI samples proposed in this work plan. 
DOE/RL-91-07, Rev。 0

Figure 4-1. Final Remedy Selection Process.

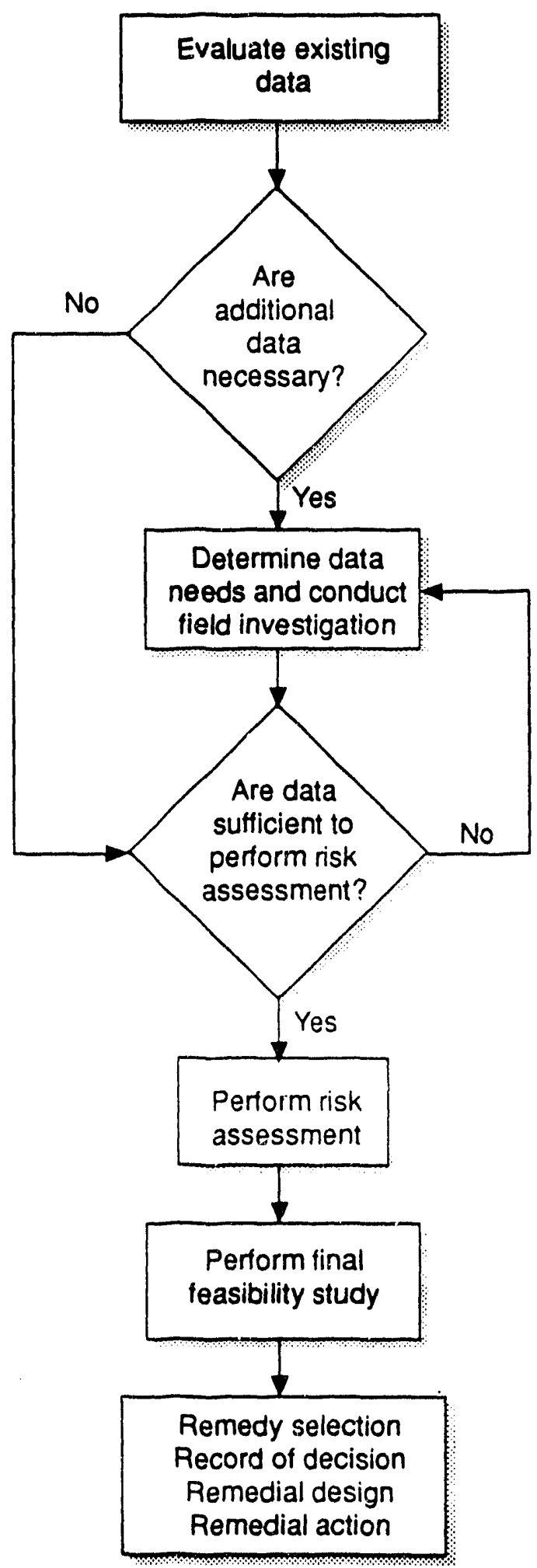


DOE/RL-91-07, Rev. 0

Figure 4-2. Investigations at High Priority Liquid Waste Sites.

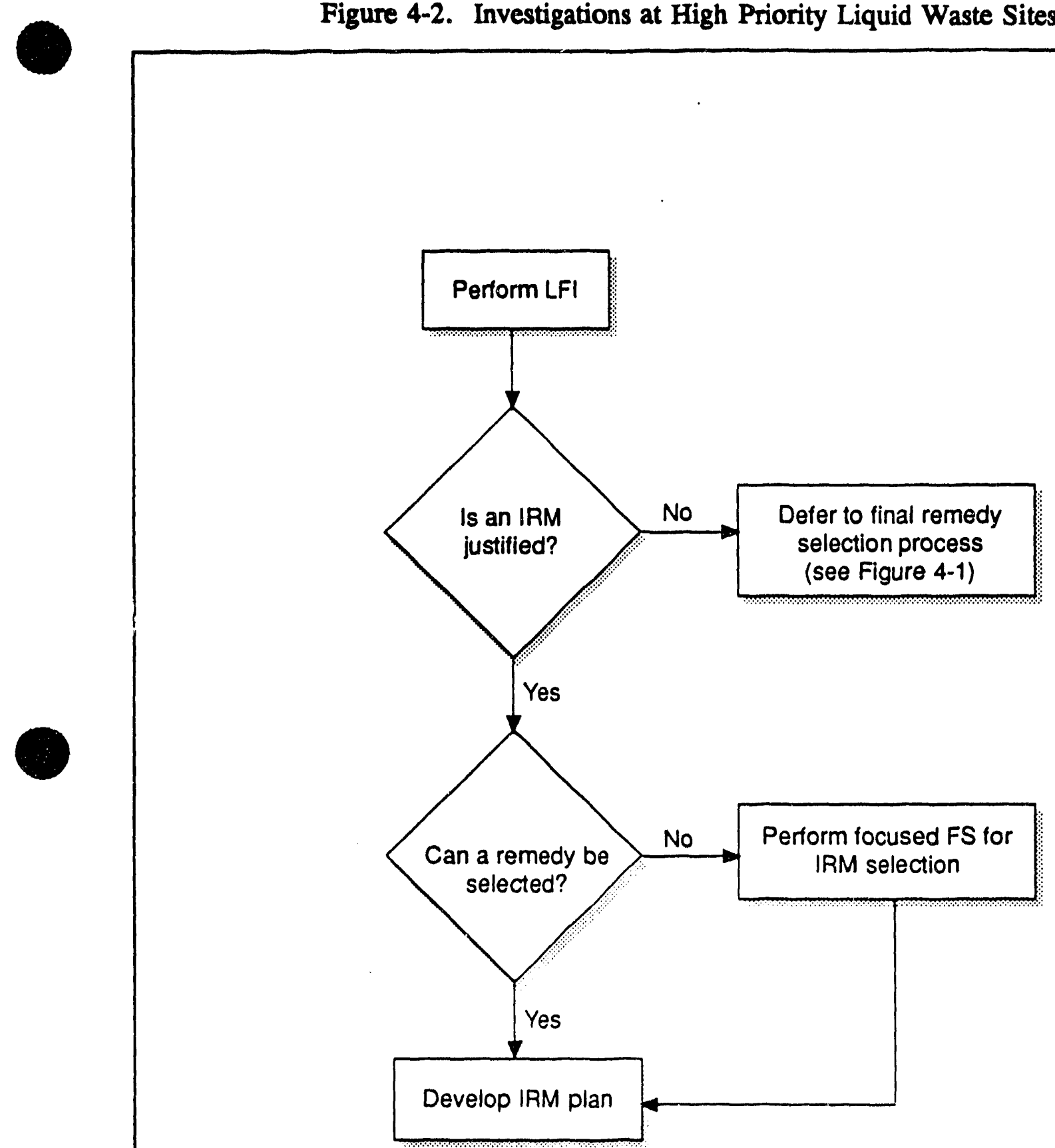


Figure 4-3. Investigations at Lower Priority Liquid Waste Sites and Solid Waste Facilities Where Data from Analog Facilities are Used.

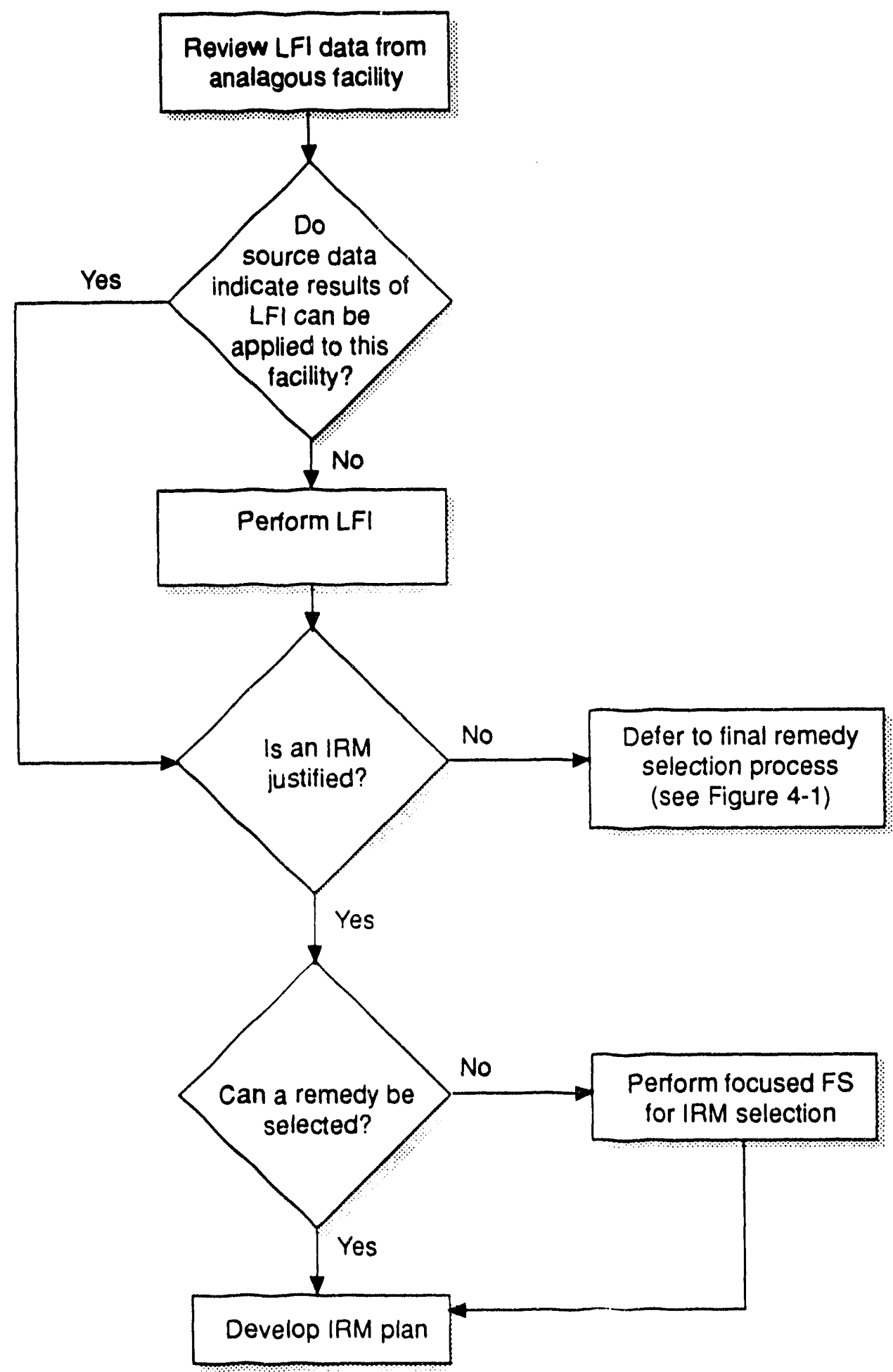


DOE/RL-91-07, Rev. 0

Figure 4-4. Investigations at Decommissioned Facilities.

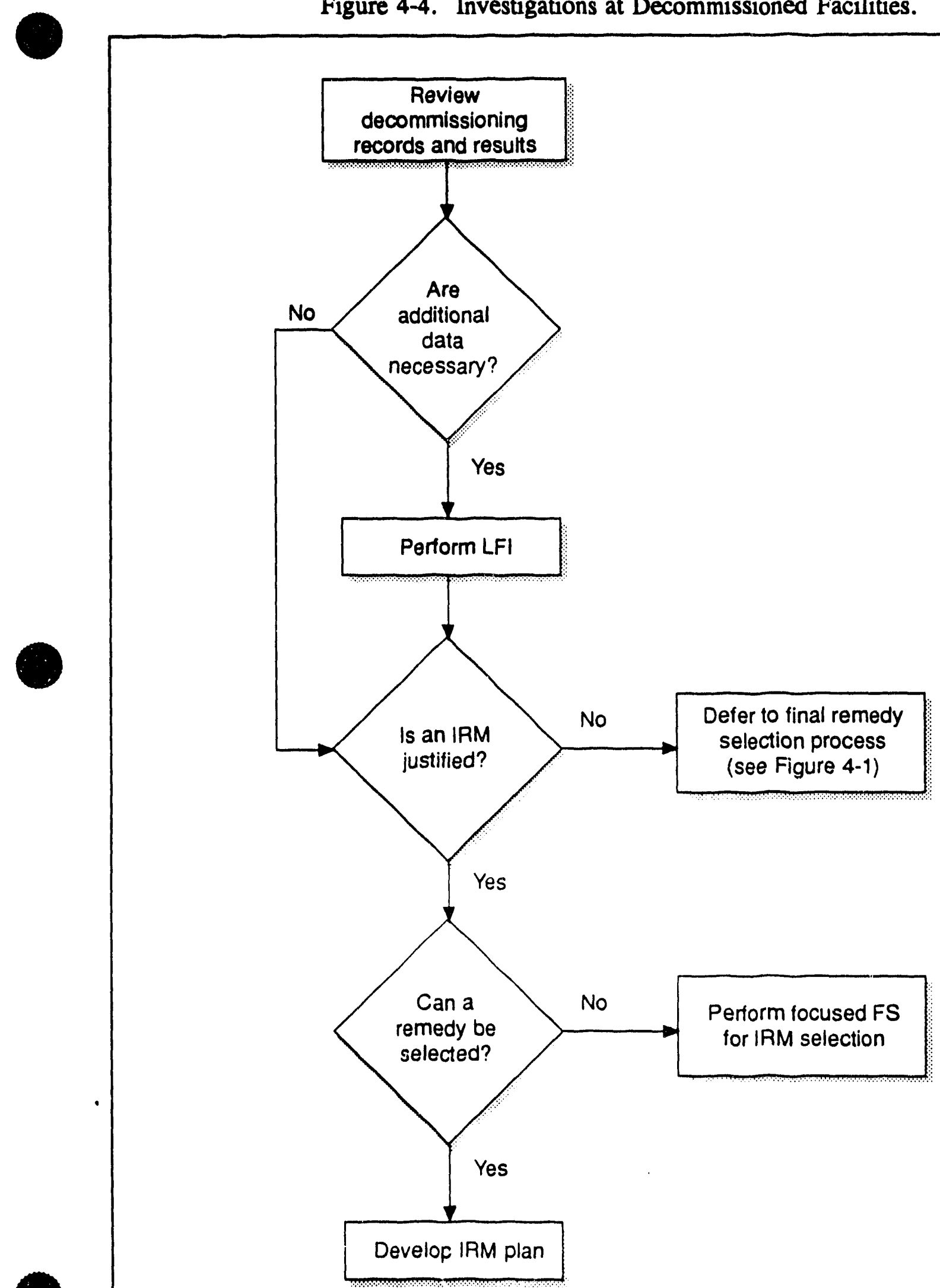


Table 4-1. Investigative Approach for the 100-BC-2 Operable Unit. (1 of 3)

\begin{tabular}{|c|c|c|c|c|c|c|c|c|}
\hline है & 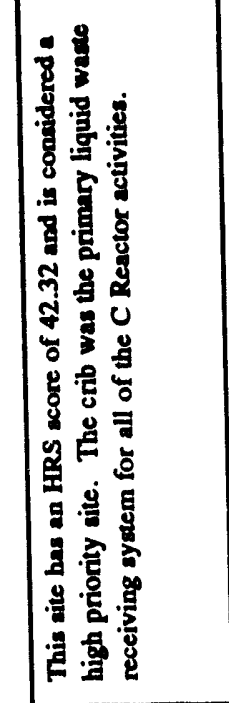 & 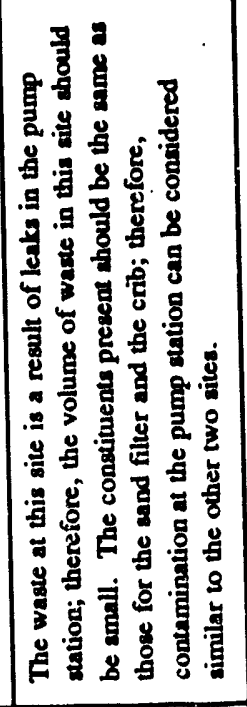 & 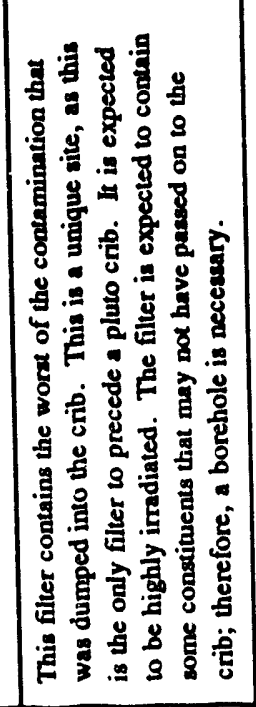 & 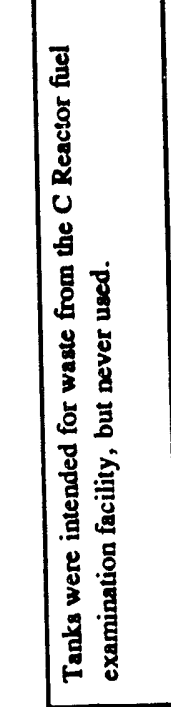 & 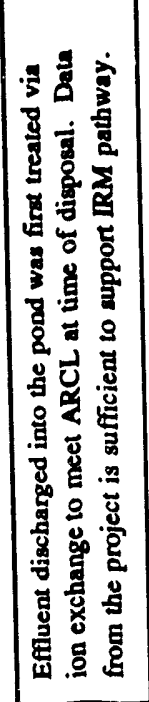 & \multicolumn{3}{|c|}{ 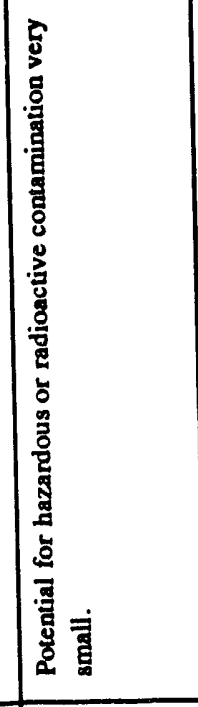 } \\
\hline 勇鄫 & $\mid \frac{3}{5}$ & $\frac{9}{3}$ & $\mid \begin{array}{l}\frac{5}{3} \\
\frac{1}{3}\end{array}$ & 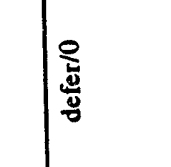 & $\mid \frac{9}{3}$ & \\
\hline 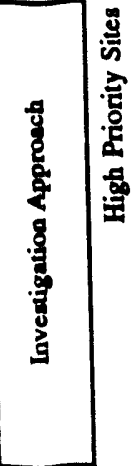 & 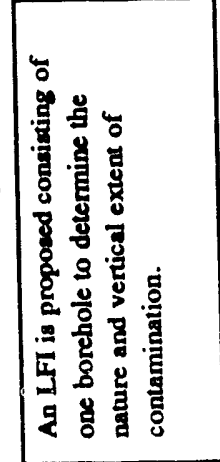 & 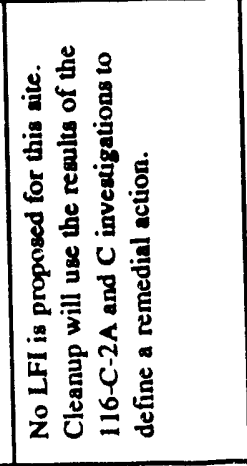 & 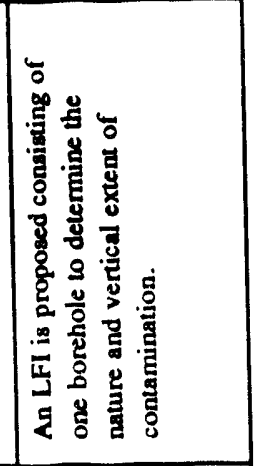 & 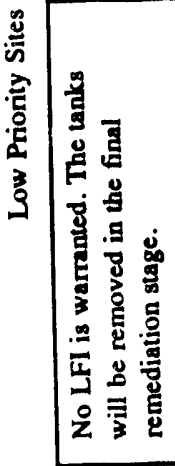 & 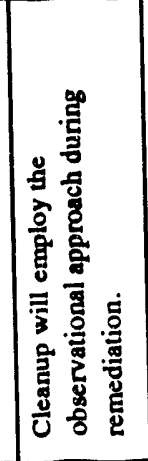 & \multicolumn{3}{|c|}{ 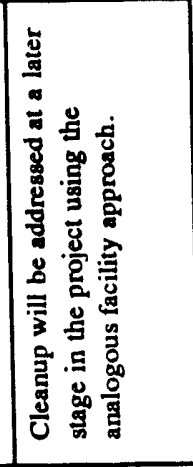 } \\
\hline 章 & 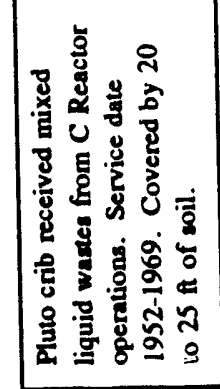 & 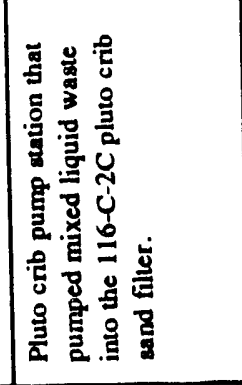 & 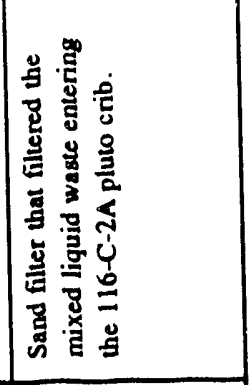 & 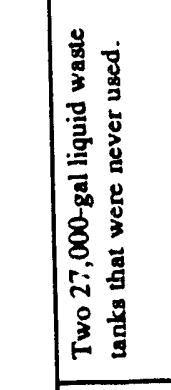 & 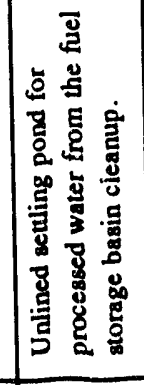 & 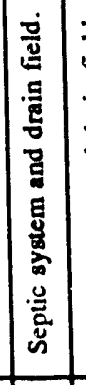 & 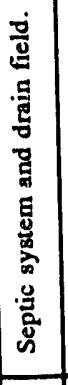 & 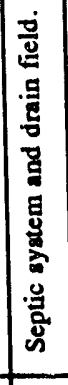 \\
\hline$\frac{g}{\frac{9}{2}}$ & 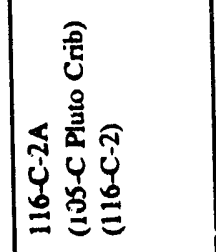 & 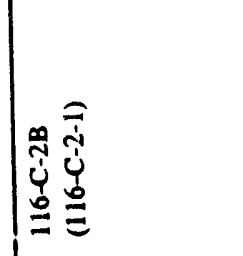 & 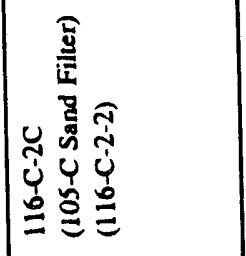 & 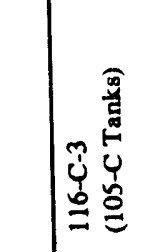 & 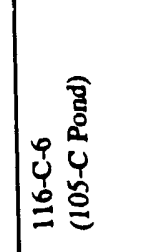 & 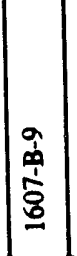 & 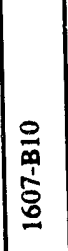 & 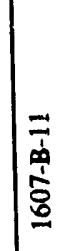 \\
\hline
\end{tabular}



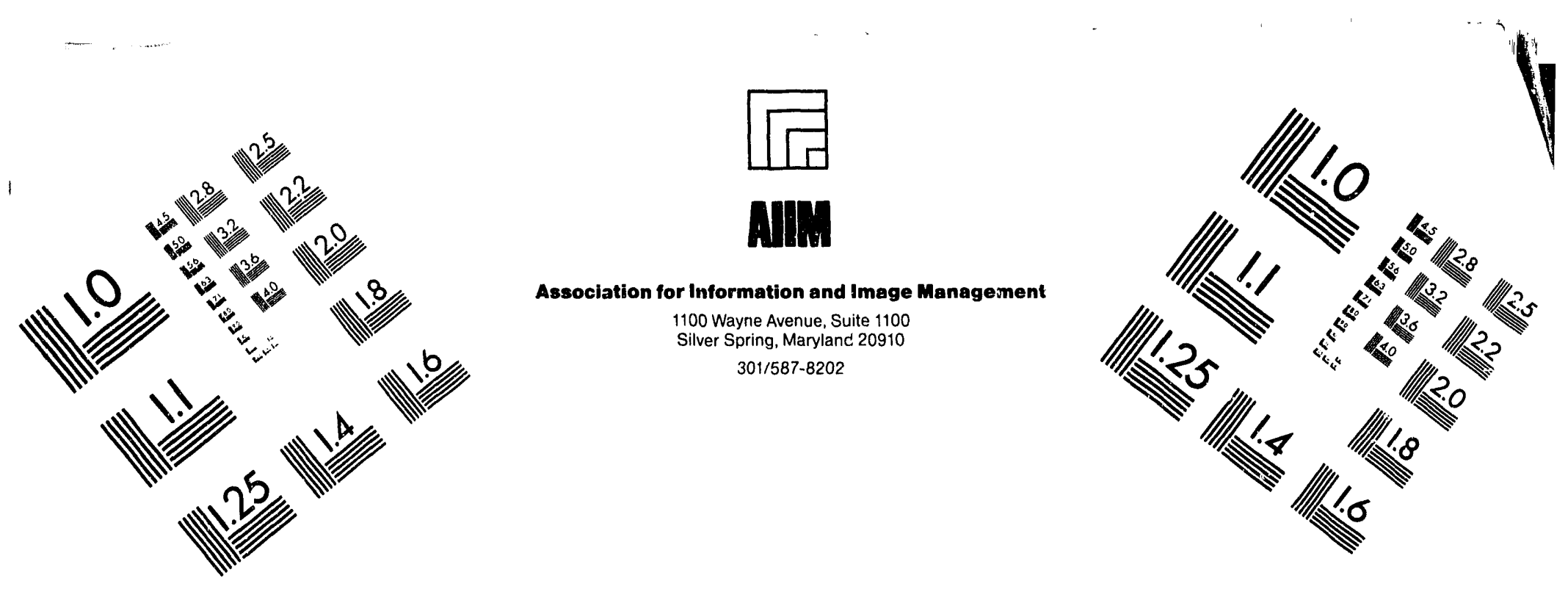

\section{Centimeter}

Association for Information and Image Management

1100 Wayne Avenue, Suite 1100

Silver Spring, Maryland 20910

$301 / 587-8202$

$\begin{array}{llllllllllllllll}1 & 2 & 3 & 4 & 5 & 6 & 7 & 8 & 9 & 10 & 11 & 12 & 13 & 14 & 15 & \mathrm{~mm}\end{array}$

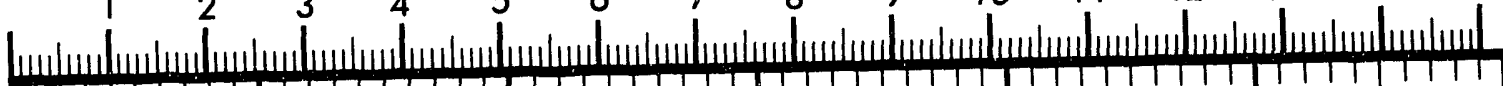

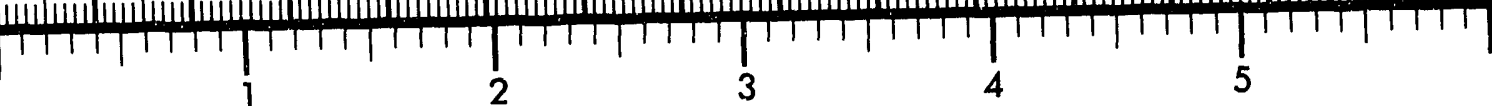
Inches
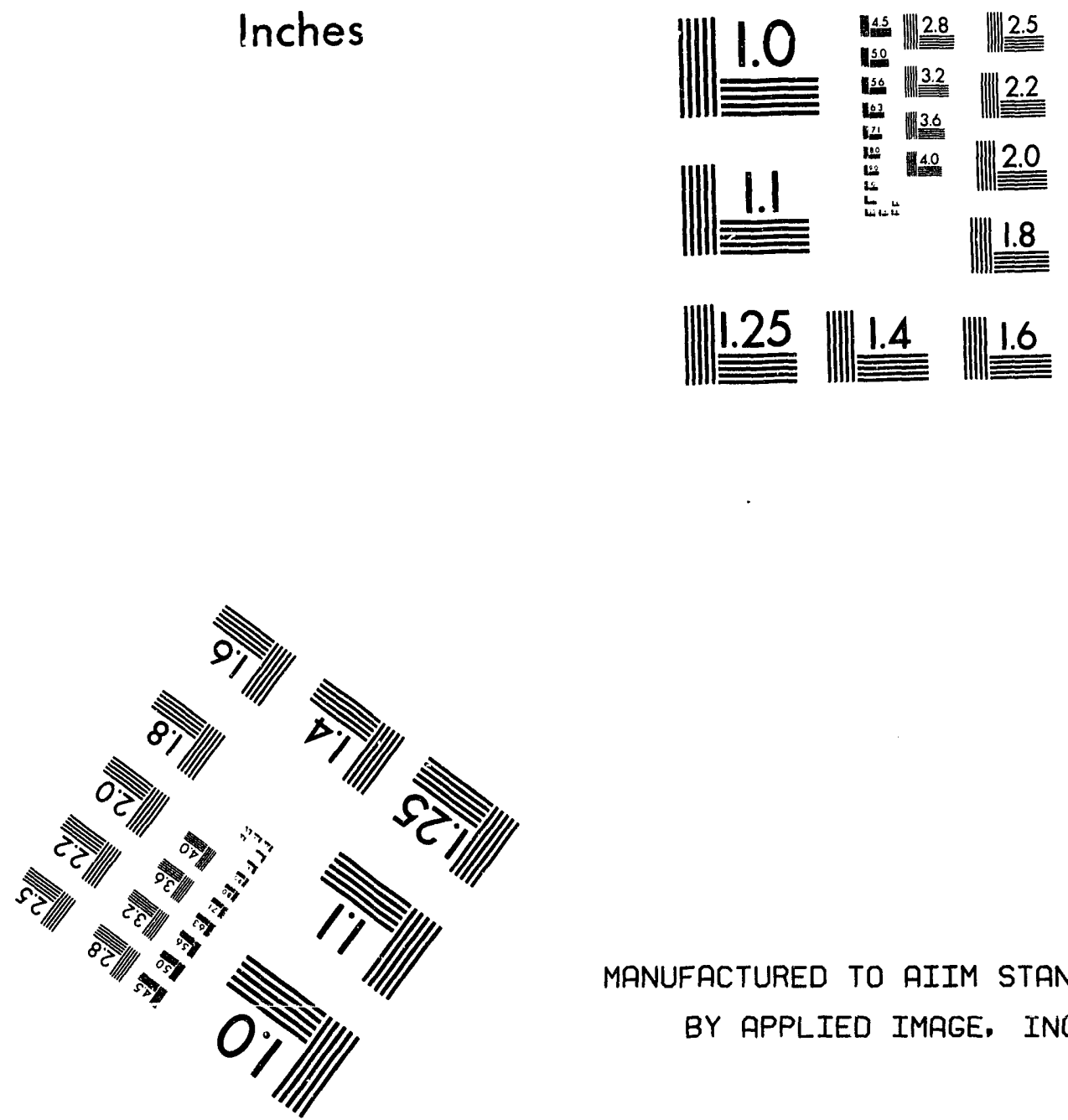

MANUFACTURED TO AIIM STANDARDS

BY APPLIED IMAGE, INC.

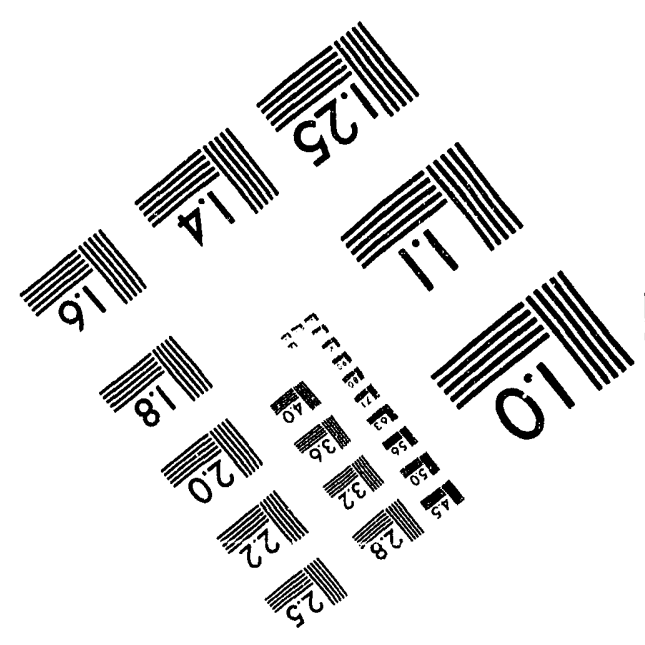



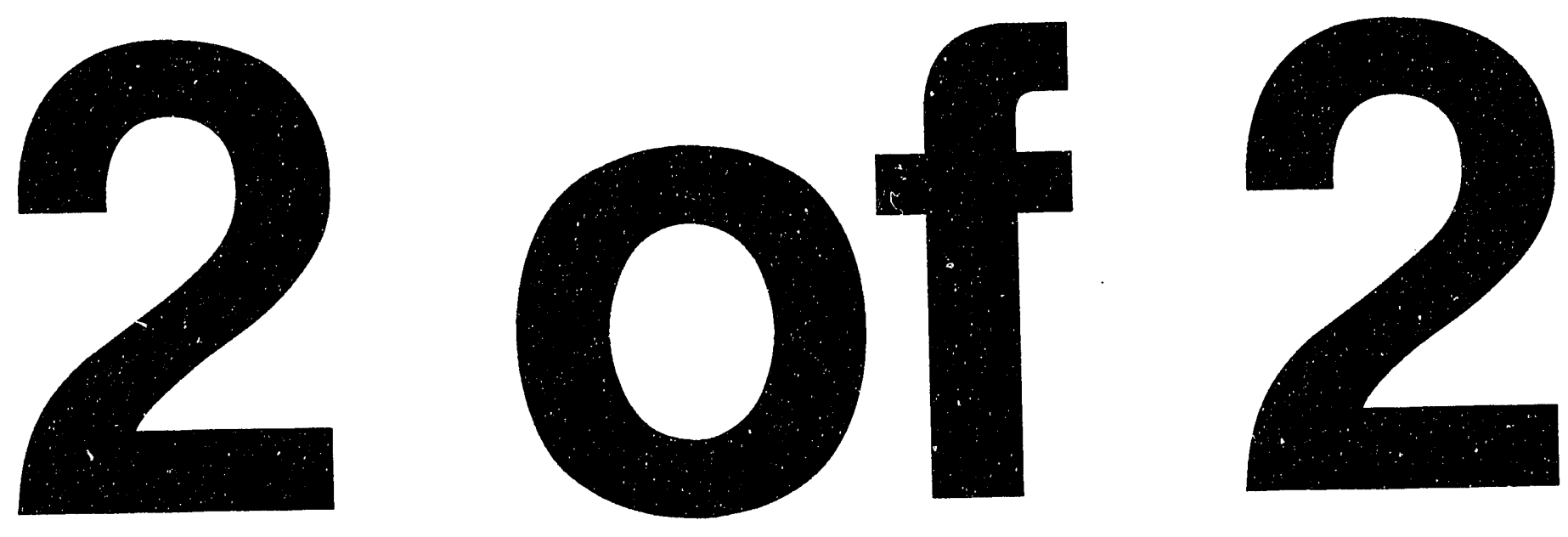
DOE/RL-91-07, Rev. 0

Table 4-1. Investigative Approach for the 100-BC-2 Operable Unit. (2 of 3)

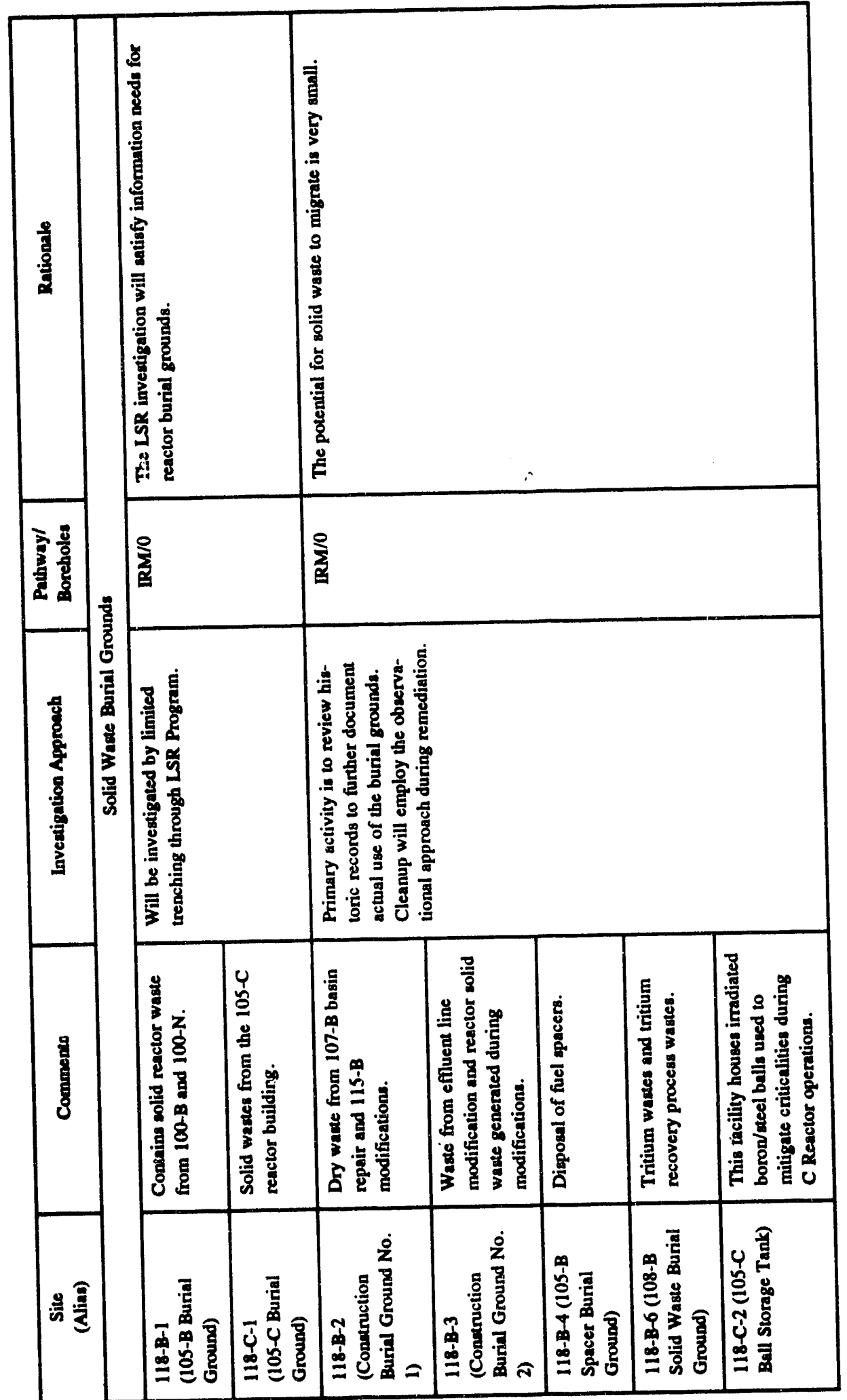


DOE/RL-91-07, Rev. 0

Table 4-1. Investigative Approach for the 100-BC-2 Operable Unit. (3 of 3)

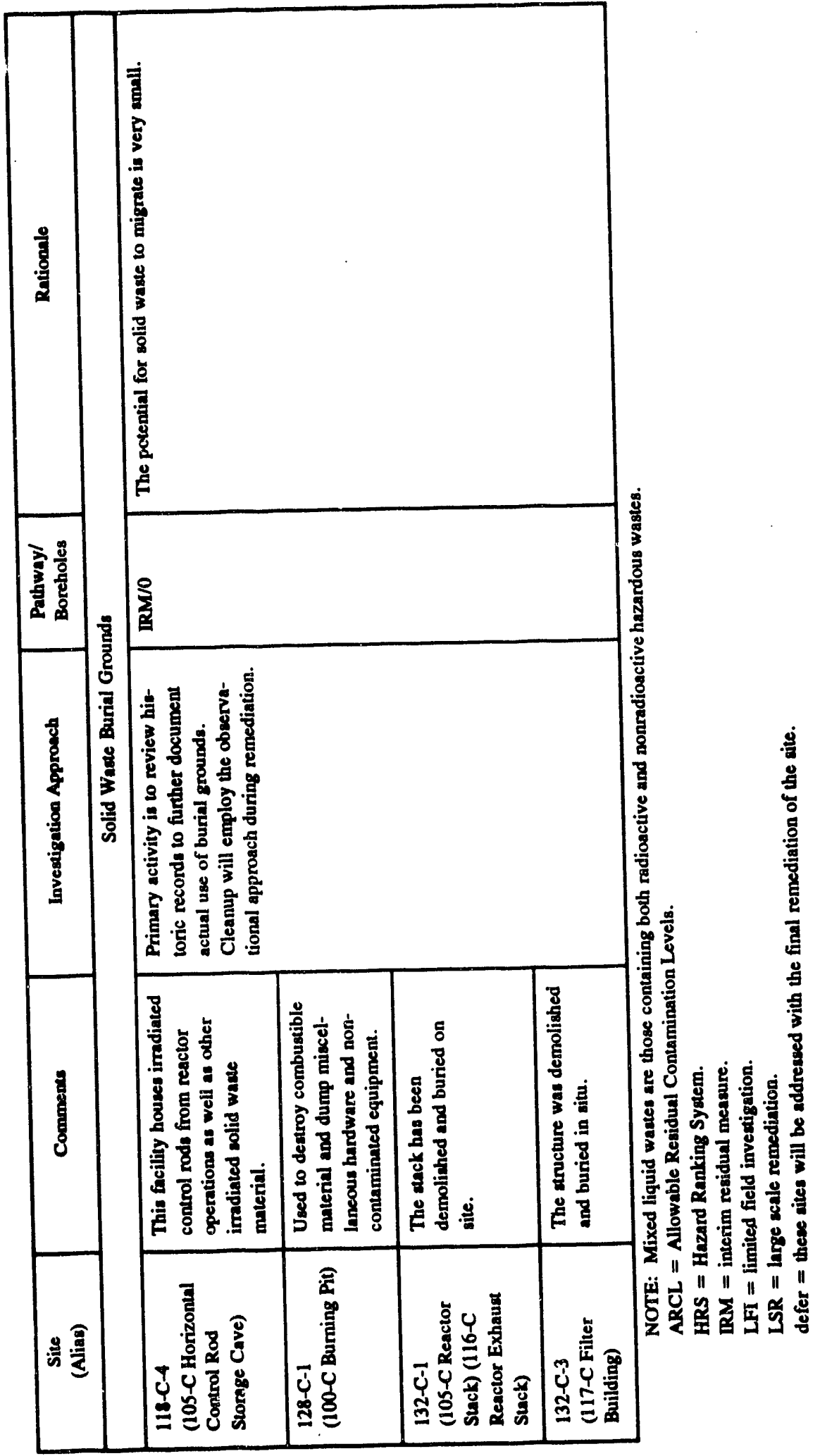


Table 4-2. Data Needs Summary for the 100-BC-2 Operable Unit. (1 of 3)

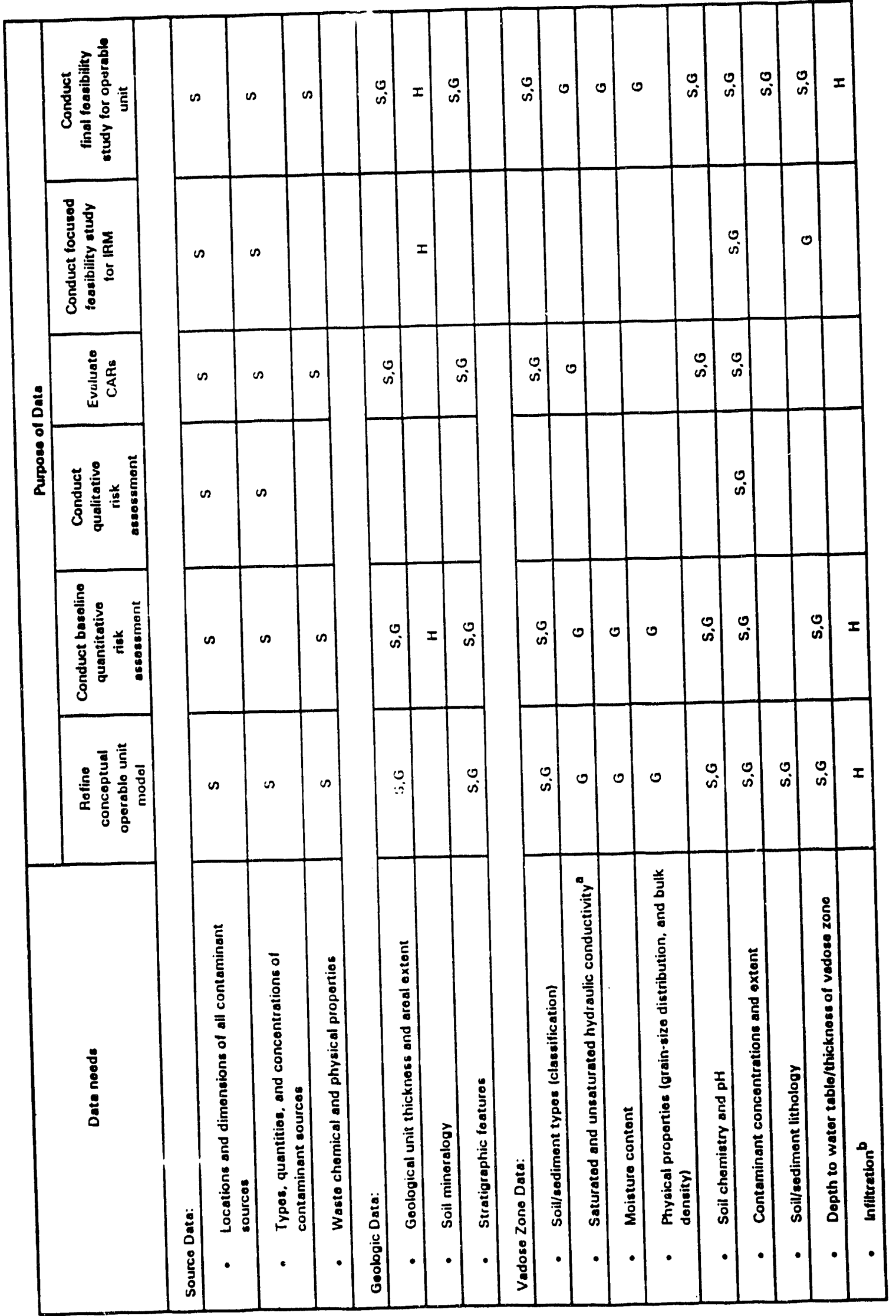


DOE/RL-91-07, Rev. 0

Table 4-2. Data Needs Summary for the 100-BC-2 Operable Unit. (2 of 3)

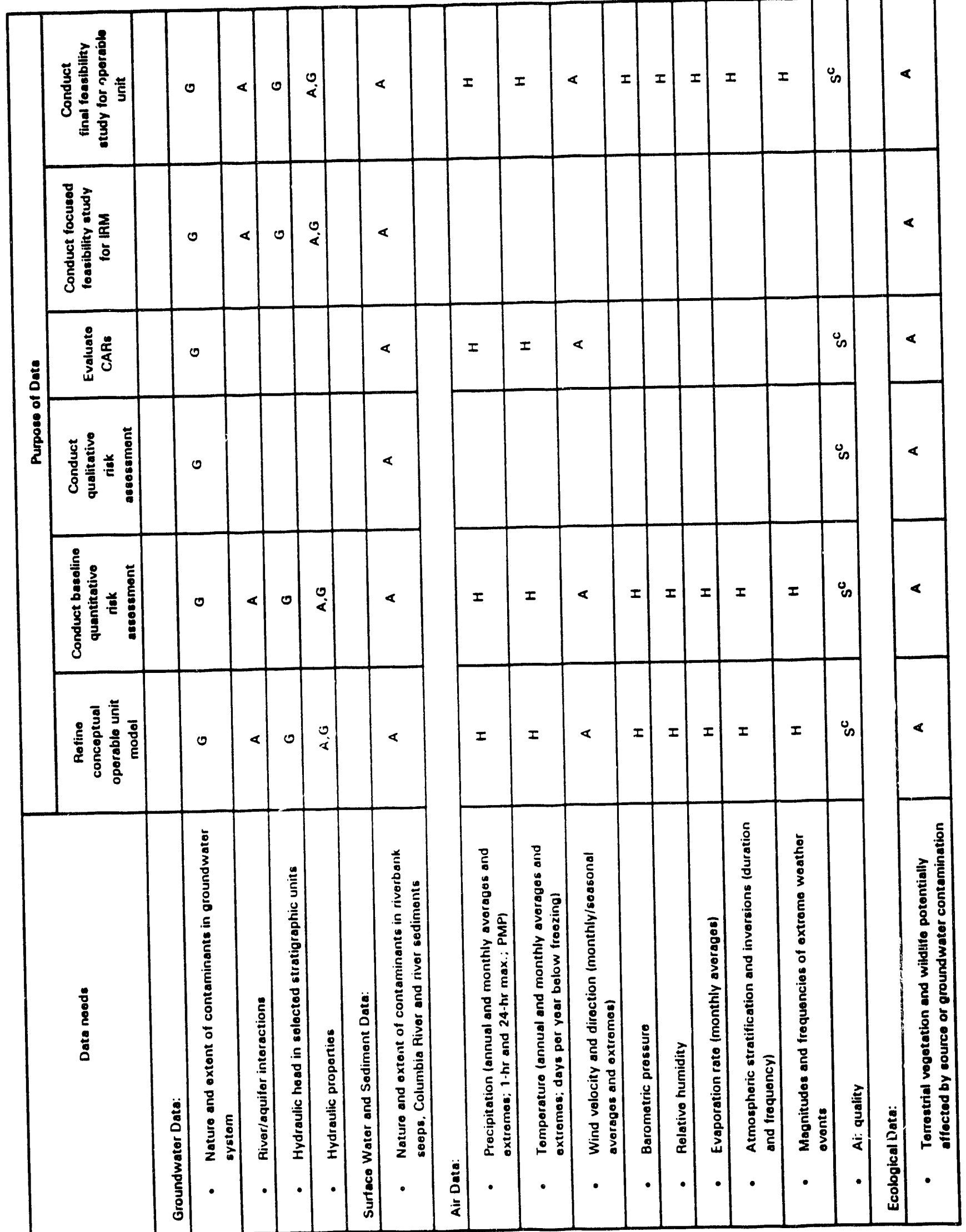


Table 4-2. Data Needs Summary for the 100-BC-2 Operable Unit. (3 of 3)

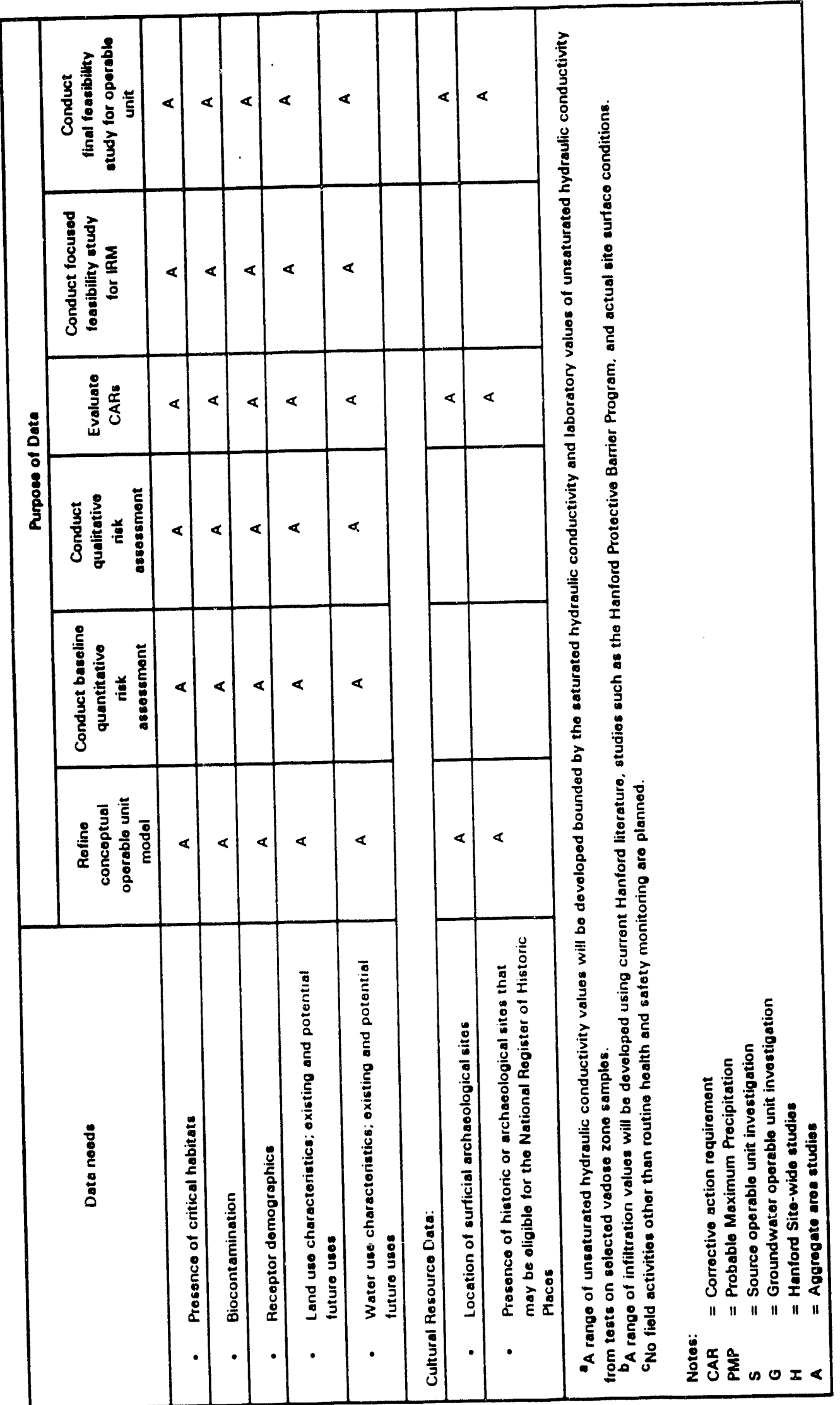


DOE/RL-91-07, Rev. 0

Table 4-3. Data Quality Objectives for the 116-C-2A Pluto Crib LFI.

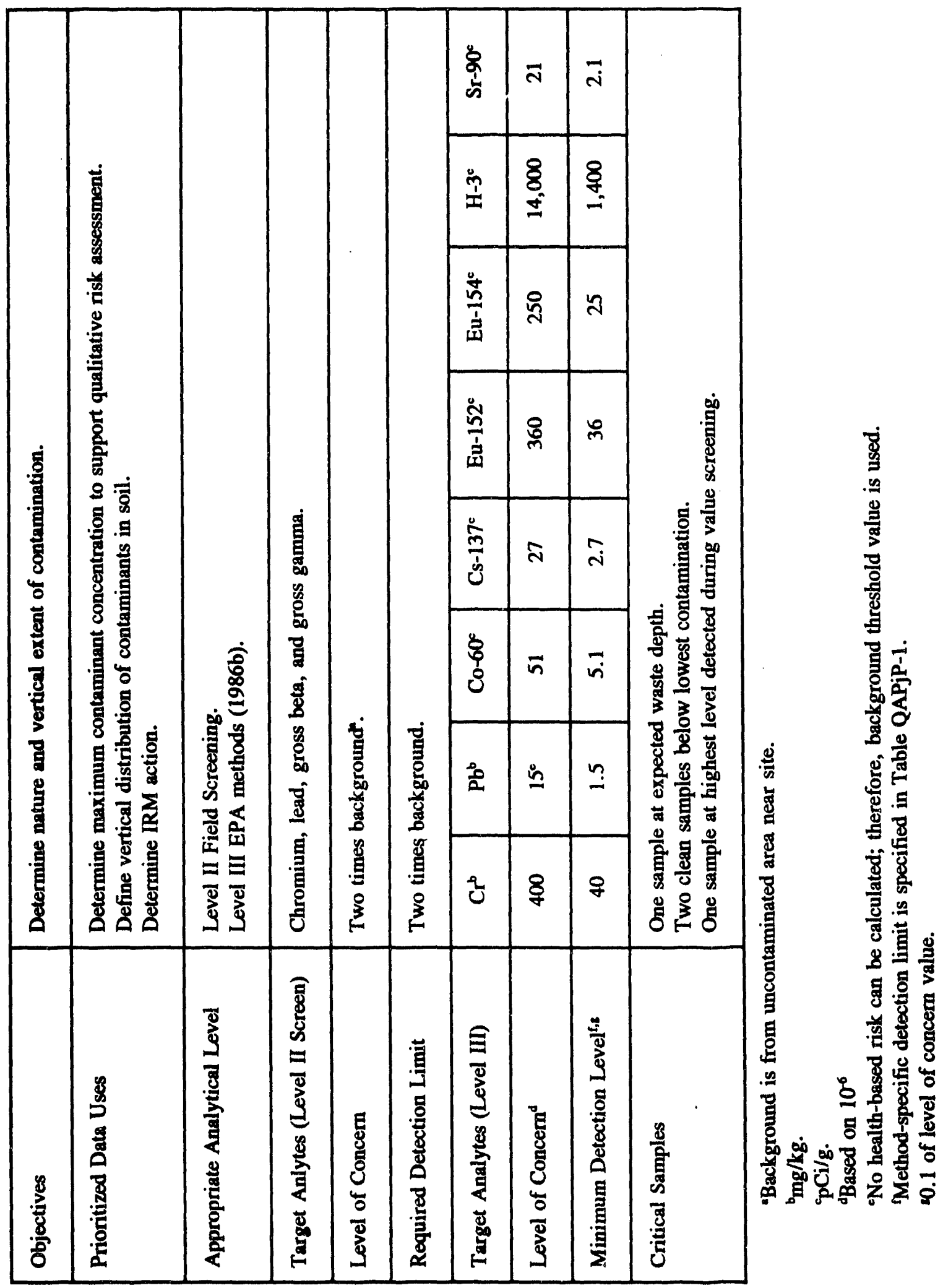


DOE/RL-91-07, Rev. 0

Table 4-4. Data Quality Objectives for the 116-C-2C Pluto Crib Sand Filter LFI.

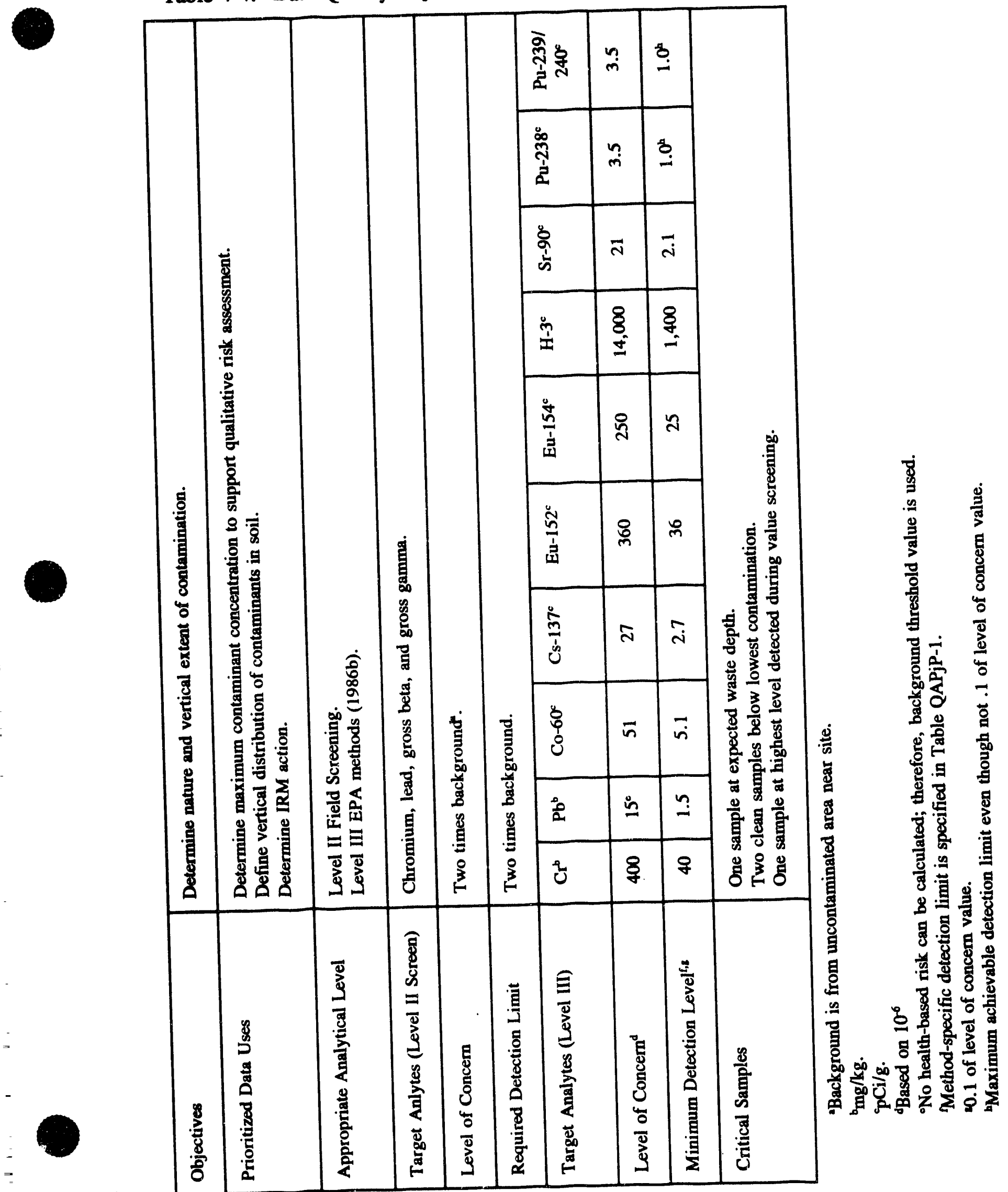


DOE/RL-91-07, Rev. 0

Table 4-5. Analagous Sites for the 100-BC-2 Operable Unit.

\begin{tabular}{|c|c|c|c|c|}
\hline $\begin{array}{c}100-\mathrm{BC}-2 \\
\text { Operable Unit } \\
\text { Waste Site }\end{array}$ & $\begin{array}{c}\text { 100-D/DR } \\
\text { Area }\end{array}$ & 100-H Area & 100-K Area & 100-F Area \\
\hline 116-C-6 Pond & $\begin{array}{l}116-\mathrm{D}-10 \\
116-\mathrm{DR}-10 \\
\end{array}$ & & & \\
\hline $\begin{array}{l}\text { 128-C-1 Burn } \\
\text { Pit }\end{array}$ & $\begin{array}{l}128-D-1 \\
128-D-2\end{array}$ & $\begin{array}{l}128-\mathrm{H}-1 \\
128-\mathrm{H}-2\end{array}$ & & $\begin{array}{l}128-\mathrm{F}-1 \\
128-\mathrm{F}-2\end{array}$ \\
\hline $\begin{array}{l}118-\mathrm{B}-1 \text { and } \\
118-\mathrm{C}-1 \text { Burial } \\
\text { Grounds }\end{array}$ & $\begin{array}{l}118-\mathrm{D}-1 \\
118-\mathrm{D}-2 \\
118-\mathrm{D}-3\end{array}$ & $118-\mathrm{H}-1$ & & $\begin{array}{l}118-\mathrm{F}-1 \\
118-\mathrm{F}-2\end{array}$ \\
\hline 132-C-1 Stack & & $132-\mathrm{H}-1$ & & $132-\mathrm{F}-4$ \\
\hline $\begin{array}{l}\text { Effluent } \\
\text { discharge } \\
\text { pipelines and } \\
\text { valves } \\
\end{array}$ & $\begin{array}{l}\text { Effluent } \\
\text { discharge } \\
\text { pipelines and } \\
\text { valves }\end{array}$ & $\begin{array}{l}\text { Effluent } \\
\text { discharge } \\
\text { pipelines and } \\
\text { valves }\end{array}$ & $\begin{array}{l}\text { Effluent } \\
\text { discharge } \\
\text { pipelines and } \\
\text { valves }\end{array}$ & $\begin{array}{l}\text { Effluent } \\
\text { discharge } \\
\text { pipelines and } \\
\text { valves }\end{array}$ \\
\hline $\begin{array}{l}\text { Septic tanks } \\
\text { and drain } \\
\text { fields }\end{array}$ & $\begin{array}{l}\text { Septic tanks } \\
\text { and drain } \\
\text { fields }\end{array}$ & $\begin{array}{l}\text { Septic tanks } \\
\text { and drain } \\
\text { fields }\end{array}$ & $\begin{array}{l}\text { Septic tanks } \\
\text { and drain } \\
\text { fields }\end{array}$ & $\begin{array}{l}\text { Septic tanks } \\
\text { and drain } \\
\text { fields }\end{array}$ \\
\hline $\begin{array}{l}\text { Gas recircu- } \\
\text { lation system } \\
\text { (132-B-5) }\end{array}$ & $115-D$ & & $115-\mathrm{K}$ & \\
\hline
\end{tabular}




\subsection{REMEDIAL INVESTIGATION/FEASIBILITY STUDY TASKS}

This chapter describes the RI/FS process up through the final RI and final FS for the operable unit. The LFI tasks are designed to provide information needed to meet the DQO identified in Chapter 4. Environmental monitoring requirements for protecting the health and safety of onsite investigators are described in the Health and Safely Plan (Appendix B).

The FS conducted in support of remedy selection during the RI/FS process are described in Section 5.2 of the 100-BC-1 operable unit (DOE-RL 1992b). The contents of the section discussing the FS process is referenced to the $100-\mathrm{BC}-1$ work plan. A detailed analysis of remedial alternatives for IRM will be conducted as part of the focused FS, and an analysis for operable unit remedial measures will be cr-fucted as part of the final FS. Both the focused and final FS will use information provided by the analysis of generic remedial alternatives completed as part of the 100 Area Phase I and II FS.

\subsection{REMEDIAL INVESTIGATIONS}

\subsubsection{LFI and the 100 Aggregate Area and Hanford Site Studies}

To satisfy the data needs and DQO specified in Chapter 4, the following tasks will be performed during the LFI.

$\begin{array}{ll}\text { Task } 1- & \text { Project Management } \\ \text { Task } 2- & \text { Source Investigation } \\ \text { Task } 3- & \text { Geological Investigation } \\ \text { Task } 4- & \text { Surface Water and Sediments Investigation } \\ \text { Task } 5 \text { - } & \text { Vadose Zone Investigation } \\ \text { Task } 6- & \text { Groundwater Investigation } \\ \text { Task } 7- & \text { Air Investigation } \\ \text { Task } 8- & \text { Ecological Investigation } \\ \text { Task } 9- & \text { Other Tasks } \\ \text { Task 10 - } & \text { Data Evaluation } \\ \text { Task } 11- & \text { Risk Assessment } \\ \text { Task } 12- & \text { Verification of ARAR } \\ \text { Task 13 - } & \text { LFI Report. }\end{array}$

The tasks and their component subtasks and activities are outlined in the following sections. Information is provided on each task to allow estimation of the project schedule and costs.

5.1.1.1 Task 1-Project Management. The details of project organization can be found in Chapter 7 of the $100-\mathrm{BC}-1$ work plan. The project management objectives throughout the course of the $100-\mathrm{BC}-2$ operable unit RI/FS are to direct and document project activities so 
that the data and evaluations generated meet the goals and objectives of the work plan, and to ensure that the project is kept within budget and schedule. The initial project management activity will be to assign individuals to roles established in Chapter 7 of the $100-\mathrm{BC}-1$ operable unit work plan. Specific subtasks that will occur throughout the LFI/focused FS and RI/FS include the following.

$\begin{array}{ll}\text { Subtask 1a } & \text { - General Management } \\ \text { Subtask 1b } & \text { - Meetings } \\ \text { Subtask 1c } & \text { - Cost Control } \\ \text { Subtask 1d } & \text { - Schedule Control } \\ \text { Subtask 1e } & \text { - Work Control } \\ \text { Subtask 1f } & \text { - Records Management } \\ \text { Subtask 1g } & \text { - Progress and Final Reports } \\ \text { Subtask 1h } & \text { - Quality Assurance } \\ \text { Subtask 1i } & \text { - Health and Safety } \\ \text { Subtask 1j } & \text { - Community Relations. }\end{array}$

Each of these subtasks is described in Section 5.1.1.1 of the 100-BC-1 operable unit work plan. Further detail on schedule control, cost control, meetings, and reporting can be found in Environmental Restoration Fiela Office Management Plan (DOE-RL 1989) and the Action Plan (Ecology et al. 1990a, Attachment 2).

5.1.1.2 Task 2-Source Investigation. The source investigation for the LFI at the 100-BC-2 operable unit is composed of five subtasks and their component activities.

$\begin{array}{ll}\text { Subtask 2a } & \text { - Source Data Compilation and Review } \\ \text { Subtask 2b } & \text { - Geodetic Control } \\ \text { Subtask 2c } & \text { - Field Activities } \\ \text { Subtask 2d } & \text { - Laboratory Analysis and Data Validation } \\ \text { Subtask 2e } & \text { - Source Data Evaluation. }\end{array}$

These subtasks will be conducted to identify sources, locations, and potential contamination associated with each high-priority sites and identified low priority sites as agreed to by the DOE, EPA, and Ecology. As described in the following subtasks, not all activities will be conducted at each site.

5.1.1.2.1 Subtask 2a-Source Data Compilation and Review. A search for $100 \mathrm{~B} / \mathrm{C}$ Area documents, photographs, and drawings has been completed as part of the 100-BC-1 and 100-BC-5 operable unit LFI. Review of this material has provided, and will continue to provide additional information about source units or potential source areas to focus all subsequent investigative tasks and subtasks. The source data compilation subtask consists of reviewing the existing information on 100-BC-2 operable unit waste sites to more accurately and completely identify the potential sources of contamination within the operable unit. Historians are also conducting interviews and document searches to compile information related to the operations conducted in the $100-\mathrm{BC}-2$ operable unit. Table 5-1 lists the data gaps identified in this work plan. 
Any data gathered during LFI at analogous waste sites within the 100-BC-2 operable unit or in other 100 Area operable units will be compiled. These data will be evaluated to determine its applicability to analogous waste units in the $100-\mathrm{BC}-2$ operable unit and will be used to focus subsequent LFI.

5.1.1.2.2 Subtask $2 \mathrm{~b}$--Geodetic Control. The objectives of this activity are to provide horizontal and vertical control for sampling points and to document all sample point locational data on an operable-unit-wide basis. A topographic base map for the operable unit has been developed using computer-aided design at a scale of 1:2,000 that shows elevation contours at $0.5-\mathrm{m}(1.5-\mathrm{ft})$ intervals. Horizontal control will be provided for sampling points established for completing the borehole soil sampling activities.

Locations of soil boring samples collected during vadose zone sampling will be surveyed for both horizontal coordinates and vertical elevations. The National Geodetic Vertical Datum of 1929 will be used for vertical alignment and the North American Datum of 1983 will be used for horizontal coordinates. Subtask $2 b$, geodetic control, will continue throughout the field program.

5.1.1.2.3 Subtask 2c-Field Activities. There are no source investigation field activities proposed for the $100-\mathrm{BC}-2$ operable unit. The source data compilation and review has supplied sufficient information to bias our investigation to include only the two proposed boreholes.

5.1.1.2.4 Subtask 2d-Laboratory Analysis and Data Validation. Samples collected will be analyzed for the constituents specified in Tables 4-3 and 4-4. Analysis will be performed using the methods identified in Appendix A (Table QAPjP-1). Routine analytical detection limits and quantitation limits, and precision and accuracy requirements are specified in Table QAPjP-1. No data validation will be performed for the LFI samples.

5.1.1.2.5 Subtask 2e-Source Data Evaluation. Additional existing information compiled under Subtask 2a, Source Data Compilation and Review, will be evaluated and incorporated into the investigation as appropriate.

5.1.1.3 Task 3-Geologic Investigation. The geologic investigation will further characterize the geology of the operable unit. Because geological data needs of the $100-\mathrm{BC}-2$ operable unit vadose zone investigations overlap with those of the 100-BC-5 operable unit groundwater investigation, the geological investigation will require an integrated compilation of geologic information from both the source and groundwater operable units. To avoid duplication of effort, the geologic investigation has been performed as part the 100-BC-5 groundwater operable unit, and is described in Section 5.1.3 of that work plan (DOE-RL 1992b).

5.1.1.4 Task 4-Surface Water and Sediments Investigation. No surface water and sediments are included within the boundaries of the 100-BC-2 operable unit. The subtasks for the surface water and sediments investigation for the $100 \mathrm{~B} / \mathrm{C}$ Area will be performed as 
part of an aggregate area investigation for the 100 Area, and are described in the 100-BC-5 operable unit work plan (DOE-RL 1992b, Appendix D-1).

5.1.1.5 Task 5-Vadose Zone Investigation. The objective of this task is to define the nature and vertical extent of contamination related to waste disposal sites at the 100-BC-2 operable unit, to define relevant migration paths between the disposal units and potentially contaminated media, especially groundwater, and to support the selection of IRM. On the basis of existing data and judgement, the lateral extent of the contamination below liquid waste sites is expected to be limited to the size of the site (i.e., crib, trench, pond dimensions). Data obtained during the LFI will be used for the following purposes:

- refining the conceptual model

- $\quad$ supporting a qualitative risk assessment to determine cleanup levels for implementing IRM

- $\quad$ supporting a focused FS for developing and evaluating IRM alternatives.

To implement the Hanford Site Past-Practice Strategy (DOE-RL 1991a) with a bias for action, the investigation has been designed with an emphasis on the primary data needs for supporting the qualitative risk assessment and implementing IRM. However, some of the data needed for the quantitative risk assessment, the definition of ARAR, and the final FS will also be obtained.

The approach to the vadose zone investigations is to obtain information both from drilling conducted in this investigation, from drilling conducted for installation of monitoring wells in the 100 Area groundwater operable units, and information from vadose investigations at analogous facilities in other operable units. Information on the nature and vertical extent of contamination will be obtained from borings in the high priority liquid waste disposal sites identified in Table 4-1. Information from this investigation as well as those at other sites will be used to make decisions for remediation of the low-priority sites. Adaitional vadose zone information has been obtained during drilling of groundwater monitoring wells in the 100-BC-5 operable unit by screening samples and cuttings and collecting samples if contamination is indicated. Samples will also be collected near the water table to determine contamination remaining as a result of past groundwater mounding or fluctuating groundwater levels. Physical properties of the vadose zone soils required to model fate and transport for the quantitative baseline risk assessment will be obtained from both source borings and boreholes for monitoring well installations throughout the 100 Area.

The vadose zone soils investigation will consist of the following subtasks:

$\begin{array}{ll}\text { Subtask 5a } & \text { - Data Compilation } \\ \text { Subtask 5b } & \text { - Borehole Soil Sampling and Logging } \\ \text { Subtask 5c } & \text { - Soil Sample Analysis } \\ \text { Subtask 5d } & \text { - Geophysical Logging } \\ \text { Subtask 5e } & \text { - Data Evaluation. }\end{array}$


5.1.1.5.1 Subtask 5a-Data Compilation. Data from the source data compilation task described in Task 2 and data from vadose zone investigations at other 100 Area operable units will be reviewed to determine whether any modifications are needed to the drilling and sampling activities. The Task 2 activities may identify additional facilities where boring is necessary to determine the need for an IRM, or to complete the quantitative risk assessment and final remedy selection for the operable unit. In addition, data collected from the sitewide soil background investigations, described by Hoover and Legore (1991), will be reviewed. These data will be used for comparison with the vadose zone sampling data to determine presence of contamination.

5.1.1.5.2 Subtask 5b-Borehole Soil Sampling and Logging. Objectives of the boring and soil sampling activities include determining the nature and vertical extent of contamination associated with the high-priority liquid waste disposal sites in the 100-BC-2 operable unit (Figure 5-1). Sites where boreholes will initially be drilled are shown on Figure 5-1. Specific locations will be chosen to represent the "worst case" contamination, such as near locations of effluent discharge to the site, or near the center of the site if the discharge points cannot be determined. For the two limited field sampling sites proposed, there is sufficient existing information to direct the borehole location. Final borehole locations will be documented in the description of work, and final borehole coordinates will be established by a geodetic surv y following completion. Boreholes will initially be drilled at the 116-C-2A pluto crib and the 116-C-2C sand filter. Because of its relation to the crib and sand filter, the 116-C-2B pump station will be assessed using the analogous facility approach and will not be investigated during the LFI.

Boreholes will be advanced and sampled using cable-tool drilling methods and splitspoon or core-barrel samplers. Cable-tool drilling will be used for this task because of the gravels, cobbles, and boulders common to the operable unit, and because the quantity of drilling residuals is minimal and can be easily controlled compared to other drilling methods. Final methods will be described in the description of work. Procedures for borehole drilling, sample collection, handling and analysis are listed in Table QAPjP-2 in Appendix A.

Depth of the vadose zone borings will be based on field screening results for radionuclides and, where appropriate, volatiles. Radionuclides will be screened using handheld instruments with an action level of twice local background. An organic vapor monitor will be used to screen for volatile organics with an action level of $5 \mathrm{ppm}$ above local background. A more detailed discussion of field screening and the use of field screenirg instruments will be given in the description of work. Radiological screening is expected to be effective in determining the extent of contamination and depth of drilling for all the sites identified for the initial boring activities at this operable unit. At these sites, sampling will begin at $1.5-\mathrm{m}(5-\mathrm{ft})$ intervals at the point borehole cuttings fail screening criteria or at the expected waste depth, whichever comes first. Drilling and sampling will continue until two consecutive samples are screened clean of contamination. If screening continues to indicate detectable contamination to the water table, the boring will extend below the water table to permit collection of at least one sample of the aquifer matrix. 
Boreholes will be geologically logged, based on drill cuttings and the split-spoon or core samples taken at specified intervals. Borehole geologic logs will be prepared in accordance with procedures specified in the QAPjP and will be stated in the description of work. Drill cuttings and core samples will be screened with hand-held instruments for radiation and volatile organic compounds. Screening results and general observations as to drilling progress and problems will be included in each borehole log.

Soil cuttings and other investigative derived waste containing unknown, low-level, mixed radioactive waste and/or hazardous waste will be contained, stored, and disposed of according to procedures specified in Table QAPjP-2 (Appendix A) and will be stated in the description of work.

All boreholes will be abandoned following completion of the geophysical logging. Specific procedures for borehole abandonment are identified in Table QAPJP-2 and will be documented in the description of work. These procedures are written to comply with EPA requirements and Ecology (WAC 173-160).

5.1.1.5.3 Subtask 5c--Soil Sample Analysis. For the initial borings in the high priority waste sites, analyses will be conducted to determine the nature of the contamination. A reduced list of analytes will be used, derived from historical sampling and process knowledpe. Samples collected for chemical and radiological analyses will be analyzed per EPA me'hods (EPA 1986b) and standard methods, respectively. Analytical methods, routine analytical detection and quantitation limits, and precision and accuracy specified for the methods are listed in Table QAPjP-1 and will be documented in the description of work. Requirements for quality control samples are in the QAPjP.

5.1.1.5.4 Subtask 5d-Geophysical Logging. Geophysical logging will be performed in existing wells that may be located in contaminated areas, and the data will be used to determine if additional logging in new boreholes is justified. Pending the results, prior to borehole abandonment, boreholes will be geophysically logged to provide additional characterization information to supplement the soil sampling data. The following logging techniques may be used:

- Gross-gamma logging to identify changes in lithology

- Spectral-gamma logging for measuring the distribution of selected radionuclides.

The existing equipment and procedures for gross-gamma and spectral-gamma logging in use at Hanford provide acceptable data. The procedures are specified in Table QAPjP-2 and will be stated in the description of work. Spectral gamma is the preferred logging method and only in unusual or unforseen circumstances will gross gamma logging be used.

5.1.1.5.5 Subtask 5e-Data Evaluation. This task will include evaluating all the information collected during the vadose zone investigation. The emphasis of the evaluation will be to determine whether IRM should be conducted at the high-priority sites. The data from analogous facilities may also be used to evaluate the waste sites in 100-BC-2 as well as 
using data collected from the 100-BC-2 LFI to evaluate analogous sites in other operable units. Chemical data will be evaluated and compared to local and site-wide soil background data, ARAR, and threshold concentrations. Borehole logs will be evaluated to confirm or refine the conceptual geologic model of the site. Geophysical logs will be compared with data from soil sampling and will fill in data gaps between sampling locations. The data collected from the vadose zone investigation will be used in conjunction with data collectec from other tasks for selecting a final remedy for the operable unit.

5.1.1.6 Task 6-Groundwater Investigation. The groundwater investigation is being performed as part of the 100-BC-5 operable unit RJ and is described in that work plan.

5.1.1.7 Task 7-Air Investigation. Although the proposed 100-BC-2 field sampling activities include actions that may expose waste and potentially contaminated soil to the atmosphere, it is expected that there will be minimal disturbance of significant volumes of contaminated materials during these activities. Because air is not anticipated to be a significant contaminant transport medium for the $1.00-\mathrm{BC}-2$ source operable unit, no field activities other than routine health and safety air monitoring are planned for the air investigations (see DOE-RL 1992b, Appendix B). However, if the need for additional air investigation becomes apparent during the course of the project or because of experience at other projects, additional air investigations will be performed as required.

5.1.1.8 Task 8-Ecological Investigation. The ecological investigation will determine the potential biocontamination transport pathways through the environment, the critical habitat for major species, and conceptual models of human and environmental risk. The ecological investigation will provide information necessary to complete the risk assessment and to develop and evaluate a full range of remediation alternatives. These tasks will be performed as part of an aggregate area investigation for the 100 Area, in accordance with the activities addressed in the 100-BC-5 operable unit work plan (DOE-RL 1992a, Appendix D-2). Aquatic sampling will be performed on the $100-\mathrm{HR}-3$ and the $100-\mathrm{N}$ operable units to determine if further testing is necessary for the other operable units of the 100 Area.

5.1.1.9 Task 9--Other Tasks. This task has been reserved in the event that additional tasks are identified during the course of the project. One subtask, Subtask 9a--Cultural Resources Investigation, has been identified. The cultural resource investigation deals with the entire 100 Area and the 600 Area north of the Gable Mountain and south of the Columbia River, rather than individual operable units. Details of this investigation are presented in Fiscal Year 1991 Report on Archaeological Surveys of the 100 Areas, Hanford Site, Washington (Chatters et al. 1992).

5.1.1.10 Task 10-Data Evaluation. Data generated during the LFI and investigations at analogous facilities will be integrated and evaluated, coordinated with FS activities, and presented in an ongoing manner to allow decisions to be made regarding any necessary rescoping during the course of the project. The results of these evaluations will be made available to project management personnel to keep project staff informed of progress being made. 
5.1.1.11 Task 11-Risk Assessment. Both qualitative and baseline risk assessments will be conducted during the course of the RI/FS process for the 100 Area. Qualitative risk assessments based on available site data will be used to support IRM following the initial data evaluation/LFI (DOE-RL 1991b). Baseline risk assessments will be conducted after evaluation of data from ERA, IRM, LFI paths, and FS studies and, when necessary, the completion of additional field investigations.

The 100-BC-2 operable unit risk assessment process will determine the magnitude and probability of potential harm to human health or the environment by the threatened or actual release of hazardous substances from waste sites in the $100-\mathrm{BC}-2$ operable unit in the absence of an action-oriented remedial action. Both the qualitative and baseline risk assessments will be developed in accordance with the Hanford Site Baseline Risk Assessment Methodology (DOE-RL 1993). This methodology addresses both human health and environmental assessments in accordance with appropriate federal and state guidance. Only an overview of the risk assessment process is presented here; refer to the the baseline risk assessment methodology (DOE-RL 1992) for additional information.

The human health and environmental evaluations will be divided into four subtasks.

$\begin{array}{ll}\text { Subtask 11a } & \text { - Identification of Contaminants of Potential Concern } \\ \text { Subtask 11b } & \text { - Exposure Assessment } \\ \text { Subtask 11c } & \text { - Toxicity Assessment } \\ \text { Subtask 11d } & \text { - Risk Characterization. }\end{array}$

The specifics of each of these subtasks can be referenced in the 100-BC-1 operable unit work plan.

5.1.1.12 Task 12--Verification of Contaminant- and Location-Specific ARAR. The formulation of operable-unit-specific ARAR is an ongoing process throughout the RI/FS. Preliminary potential ARAR were identified and discussed in Section 3.2 of the 100-BC-1 work plan. In addition, potential ARAR for the 100 Area are currently being developed. Following the evaluation of analytical data under Task 10, contaminant-and location-specific ARAR will be reviewed and identified, based on the new knowledge of contamination at the site and the site setting. Once the potential ARAR for 100-BC-2 operable unit have been properly identified, EPA and Ecology will be asked to verify the contaminant- and location-specific ARAR. Project staff will work with the regulatory agencies and, taking operable unit-specific conditions into account, will decide which promulgated environmental standards, requirements, criteria, and limitations are actually applicable or relevant and appropriate to the 100-BC-2 operable unit.

5.1.1.13 Task 13-LFI Report. A report will be prepared on completion of the LFI. This report will consist of a preliminary summary of the characterization activities described in Tasks 1 through 12 . Information pertinent to the operable unit conceptual model will be refined, as necessary. The report will include the results of source investigations, identify the nature and vertical extent of contamination at the high-priority liquid waste disposal facilities, identify the contaminant- and location-specific ARAR, and provide a summary of 
the qualitative assessment of the risks associated with the sites. The report will include an assessment of whether thresholds are exceeded that warrant action through IRM. The LFI report will also evaluate analagous sites to those in the $100-\mathrm{BC}-2$ operable unit to aid in the determination of the need for IRM.

\subsubsection{Final Remedial Investigation}

The final RI provides any additional data and characterization needed to support selection, design, and implementation of a final remedial action for the operable unit. The final RI is performed at remaining low-priority sites where existing data are considered insufficient by the unit managers, and at any remaining high-priority sites where final cleanup criteria were not achieved by IRM. A final RI may consist of data compilation, nonintrusive investigations, intrusive investigations, and data evaluation. Analyses conducted during the final RI use data collected during the LFI, during IRM implementation, and in previous investigations.

A baseline risk assessment is performed as part of the final RI. This assessment provides a quantitative evaluation of residual risk at the operable unit after completion of the IRM, and is conducted per DOE-RL (1993). The results of this assessment are used to help determine the need for remedial action, to select the remedial action, and to determine riskbased cleanup levels for the remedial action.

The final RI is conducted in parallel with the final FS, permitting the collection of any additional data that may be identified when conducting the final FS. The final RI and the baseline risk assessment are documented in the final RI report, which is a secondary document.

\subsection{FEASIBILITY STUDIES}

The FS process for the 100 Area will be conducted on both an aggregate area and operable unit basis. Guidance for Conducting Remedial Investigations and Feasibility Studies Under CERCLA (EPA 1988a) will be used as the guidance document for the content and approach to each of the FS performed. This process includes preparation of a 100 Area FS, a focused FS, and a final FS. A description of each of the studies is provided in the 100-BC-1 operable unit work plan since the scope of this work plan focuses on the RI and stresses the incorporation by reference philosophy for all non specific information. 
Figure 5-1. High Priority Sites.
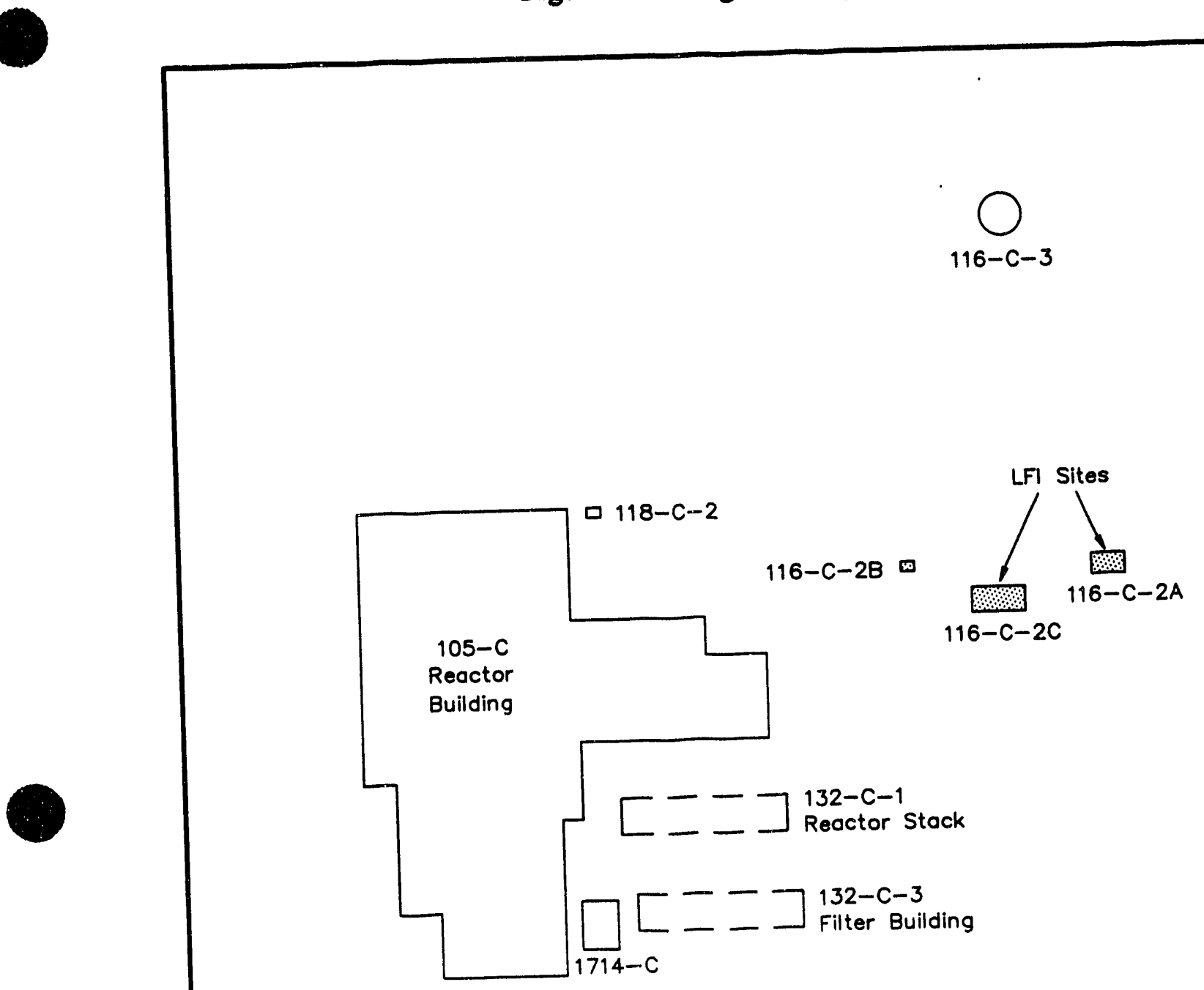

ㅁ 118-C-2

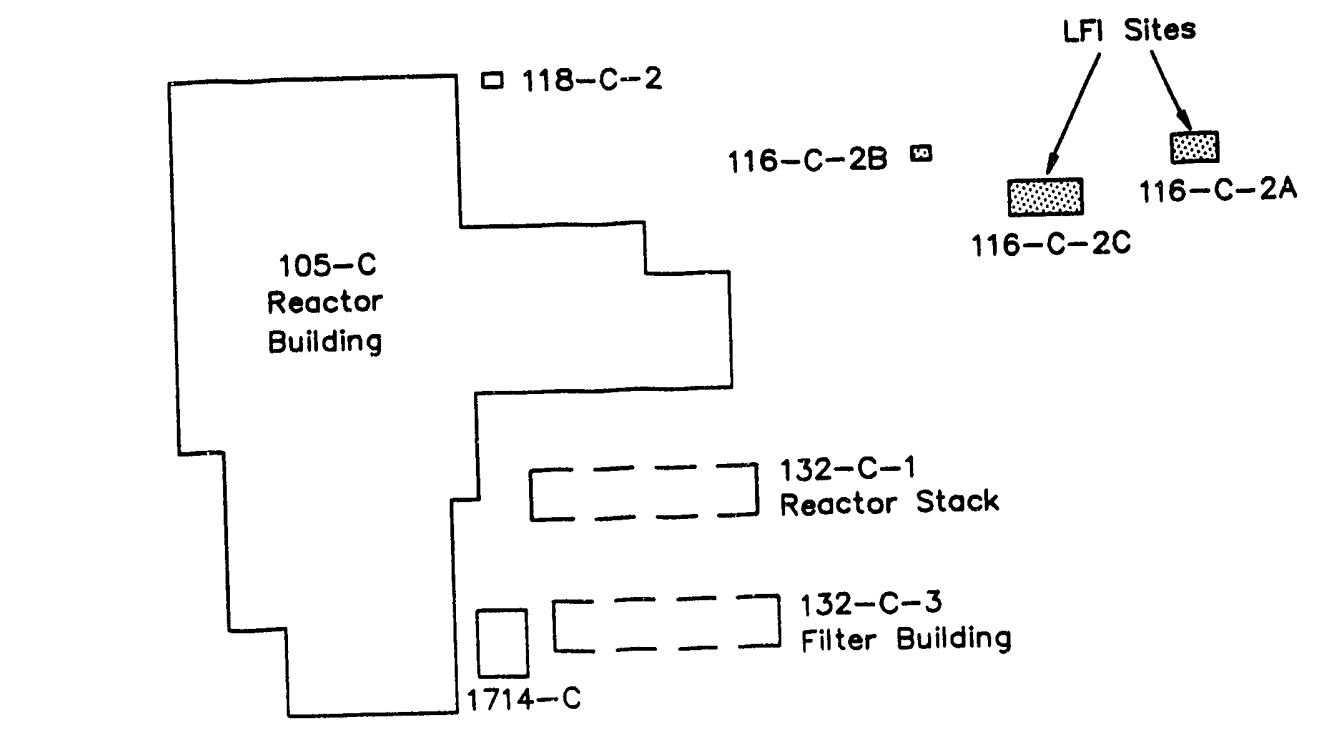

$116-c-3$

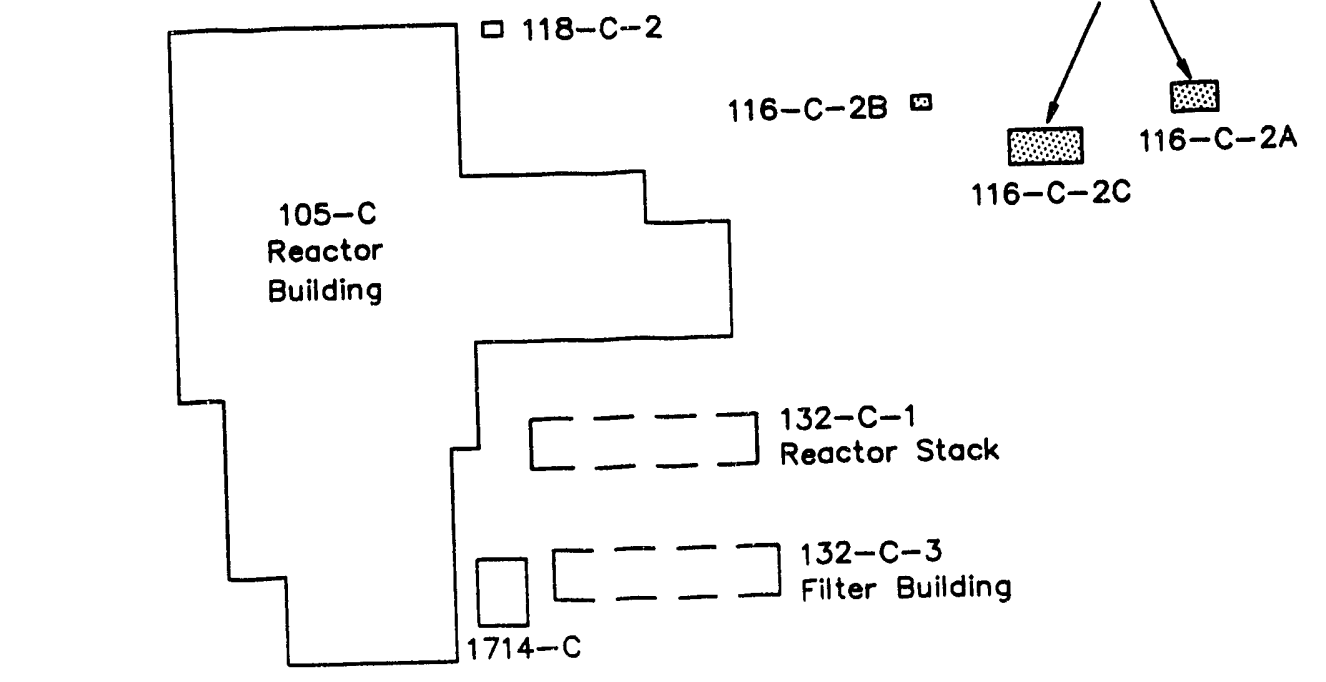

$116-C-2 C$

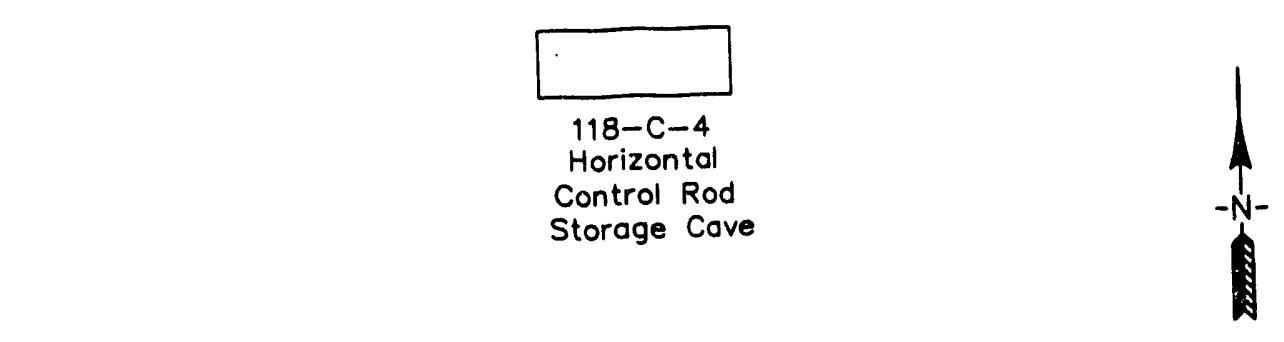

LFI Limited Field investigation

2 High Priority Sites

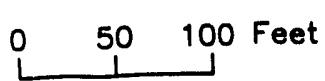


DOE/RL-91-07, Rev. 0

Table 5-1. 100-BC-2 Operable Unit Data Gaps.

\begin{tabular}{|c|c|}
\hline \multicolumn{2}{|l|}{ General Information Needs } \\
\hline Data Gap & Section in Text \\
\hline $\begin{array}{l}\text { Location and magnitude of effluent pipeline } \\
\text { leaks }\end{array}$ & 2.1 .3 .2 \\
\hline $\begin{array}{l}\text { Construction details ard location of the Gas } \\
\text { Recirculation Piping Tunnels }\end{array}$ & 2.1.3.3.4 \\
\hline $\begin{array}{l}\text { Fuel tanks for electrical backup of the } \\
\text { C Reactor }\end{array}$ & 2.1.4.5 \\
\hline Location of 1736 Building & 2.1 .3 .6 .3 \\
\hline $\begin{array}{l}\text { Disposal of filter backwash from 183-C } \\
\text { facility }\end{array}$ & 3.1.1.6 \\
\hline $\begin{array}{l}\text { Disposal of treatment residuals from the } \\
\text { treatment of the fuel storage basin wash } \\
\text { water disposed of in the } 116-C-6 \text { pond }\end{array}$ & $\begin{array}{c}2.1 .3 .4 \\
2.1 .4 .1 .2\end{array}$ \\
\hline Contents of the $118-\mathrm{C}-4$ storage cave & 2.1.3.3.1 \\
\hline $\begin{array}{l}\text { Possible contamination from the } 1714-\mathrm{C} \\
\text { solvent storage building }\end{array}$ & 3.1.1.6 \\
\hline $\begin{array}{l}\text { Possible contamination at the tank pads } \\
\text { adjacent to the } 183-\mathrm{C} \text { headhouse }\end{array}$ & 3.1 .1 .6 \\
\hline $\begin{array}{l}\text { Documented use of the 116-C-3 } \\
\text { underground tanks }\end{array}$ & 2.1.3.7 \\
\hline Organic compounds used on site & 2.1.4.5 \\
\hline
\end{tabular}


DOE/RL-91-07, Rev. 0

Table 5-2. Task Matrix.

\begin{tabular}{|c|c|c|c|c|}
\hline \multirow[b]{2}{*}{ TASK } & \multicolumn{4}{|c|}{ AREA WHERE TASK IS ADDRESSED } \\
\hline & $100-B C-2$ & $100-B C-1$ & $100-B C-5$ & $\begin{array}{l}\text { AGGREGATE } \\
\text { AREA }\end{array}$ \\
\hline Task 1-Project Management & $\mathrm{X}$ & & & \\
\hline \multicolumn{5}{|l|}{$\begin{array}{l}\text { Task 1--Project Managemeil } \\
\text { Task 2-Source Investigation }\end{array}$} \\
\hline $\begin{array}{l}\text { Subtask 2a-Source Data } \\
\text { Compilation and Review } \\
\end{array}$ & $\mathrm{X}$ & $\mathbf{X}$ & $\mathrm{x}$ & \\
\hline $\begin{array}{l}\text { Subtask 2e--Source Data } \\
\text { Evaluation }\end{array}$ & $\mathrm{X}$ & $\mathrm{X}$ & $\mathrm{X}$ & \\
\hline Task 3--Geologic Investigation & & & $\mathrm{X}$ & \\
\hline $\begin{array}{l}\text { Task 4-Surface Water and Sediments } \\
\text { Investigation }\end{array}$ & & & & $\begin{array}{l}\text { Appendix D of } 100 \\
\text { BC. } 5 \text { work plen }\end{array}$ \\
\hline \multicolumn{5}{|l|}{ Task 5-Vadose Zone Investigation } \\
\hline Subtask 5a--Data Compilation & $\mathrm{X}$ & $\mathrm{X}$ & $\mathbf{X}$ & \\
\hline $\begin{array}{l}\text { Subtask } 5 \mathrm{~b}-\text {-Borehole Soil } \\
\text { Sampling and Logging }\end{array}$ & $\mathrm{X}$ & & & \\
\hline Subtask 5c-Soil Sample Analysis & $\mathrm{X}$ & & & \\
\hline Subtask 5d-Geophysical Logging & $\mathrm{X}$ & & & \\
\hline Subtask 5e-Data Evaluation & $\mathrm{X}$ & & & \\
\hline Task 6-Groundwater Investigation & & & $\mathbf{X}$ & \\
\hline Task 7--Air Investigation & \multicolumn{4}{|c|}{ For Health and Safety only during field work } \\
\hline Task 8-Ecological Investigation & & & & $\begin{array}{l}\text { Appendix } D \text { of } 100- \\
\text { BC-5 work plan }\end{array}$ \\
\hline Task 9-Other Tasks & & & & \\
\hline $\begin{array}{l}\text { Subtask 9a-Cultural Resource } \\
\text { Invescigation }\end{array}$ & & & & $\begin{array}{l}\text { Appondix } D \text { of } 100 \\
\text { BC- } 5 \text { work plan }\end{array}$ \\
\hline Task 10-Data Evaluation & $\mathrm{X}$ & & & \\
\hline Task 11-Risk Assessment & $\mathrm{X}$ & & . & \\
\hline $\begin{array}{l}\text { Task 12--Verification of Contaminant- } \\
\text { and Location-Specific ARARs }\end{array}$ & $\mathrm{X}$ & & & \\
\hline Task 13-LFI Report & $\mathbf{X}$ & & & \\
\hline
\end{tabular}


DOE/RL-91-07, Rev. 0

\subsection{SCHEDULE}

An operable unit schedule, which supports the Tri-Party Agreement (Ecology et al. 1990a) action plan work schedule, has been prepared that details the work described in Chapter 5 of this work plan. This schedule (Figure 6-1) is the baseline against which progress will be measured. A formal change control proress has been established in the action plan and shall be used, if necessary, to modify milestones shown in the schedule. 


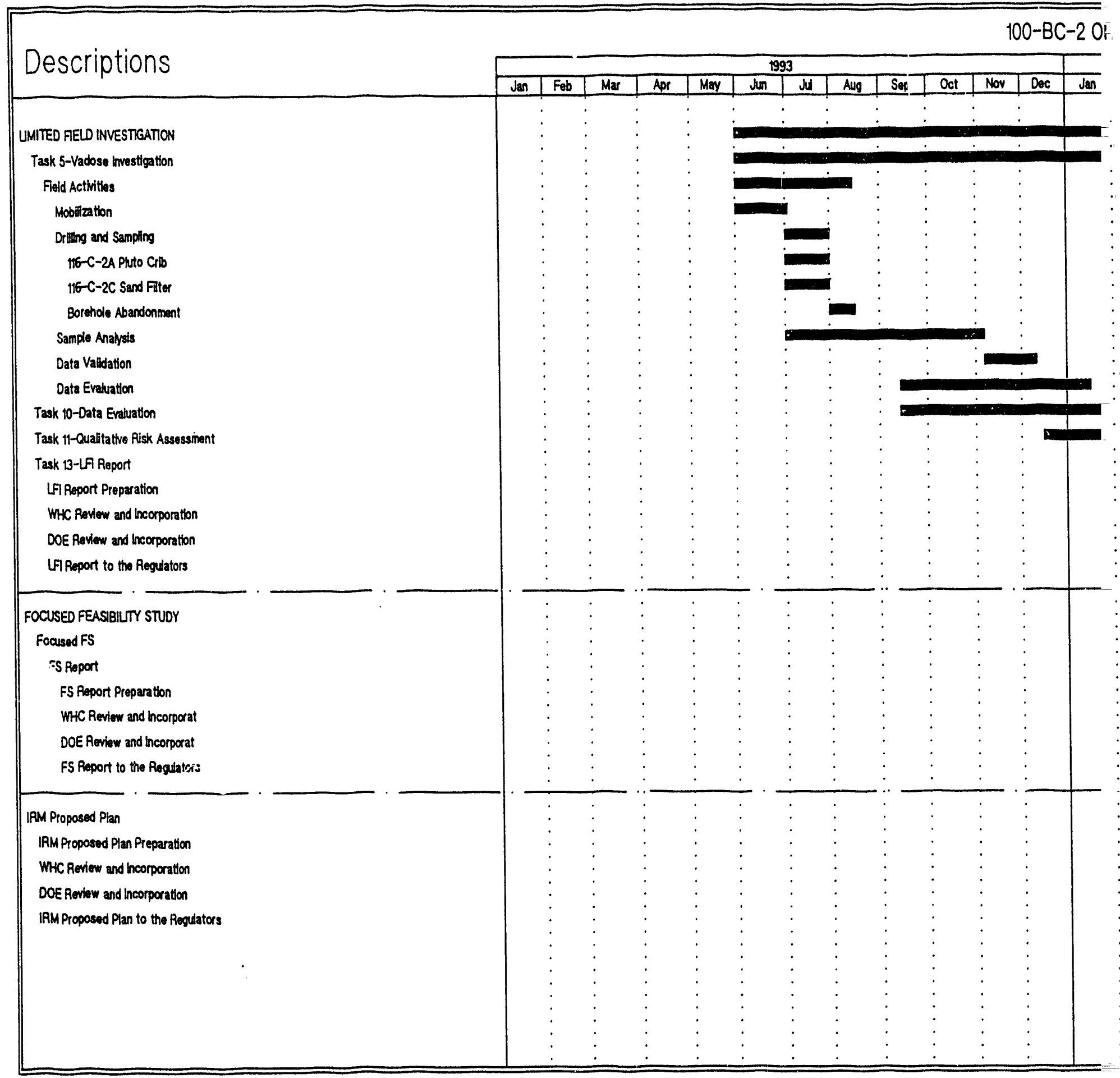


DOE/RL-91-07, Rev. 0

ERABLE UNIT

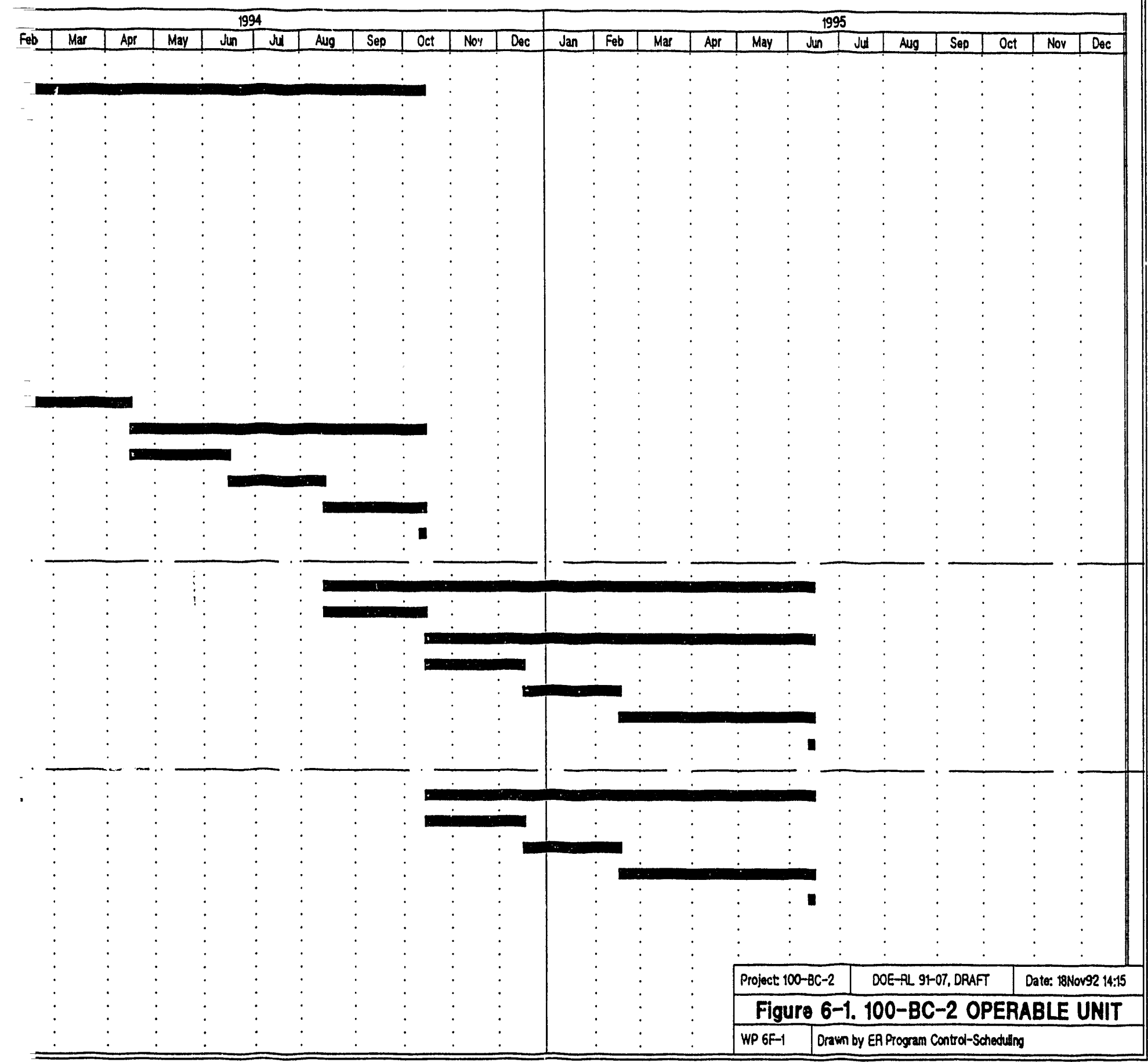




\subsection{PROJECT MANAGEMENT}

The project management chapter defines the administrative and institutional tasks necessary to support the RI/FS for the 100-BC-2 operable unit at the Hanford Site. The specifics of the project management plan can be referenced in the 100-BC-1 operable unit work plan (DOE-RL 1992b, Sections 7.1 through 7.3) since the same criteria apply to the 100-BC-2 operable unit. 


\subsection{REFERENCES}

Atomic Energy Commission 1953a, Architectural Plans and Details, 105-C crib.

Drawing \# P-8885. (Available at Westinghouse Hanford Company Drawing Center, Engineering Division, Richland, Washington.)

Atomic Energy Commission 1953b, Architectural Plans and Details, 105-C crib sump. Drawing \# P-8883. (Available at Westinghouse Hanford Company Drawing Center, Engineering Division, Richland, Washington.)

Atomic Energy Commission 1953c, Architectural Plans and Details, 105-C crib filter. Drawing \# P-8884. (Available at Westinghouse Hanford Company Drawing Center, Engineering Division, Richland, Washington.)

Atomic Energy Commission, Outside lines - Sewers, 100-B. Drawing \# M-1904-B, sheets 8 and 9. (Available at Westinghouse Hanford Company Drawing Center, Engineering Division, Richland, Washington.)

Beckstrom, J. F., 1986, ARCL Calculations for Decommissioning the 116-C Stack, UNI-3826, UNC Nuclear Industries, Richland, Washington.

CDM Federal Programs Corporation, 1987, Data Quality Objectives for Remedial Response Activities; Volume 1 - Development Process, EPA/540/G-87/003A, U.S. Environmental Protection Agency, Office of Emergency and Remedial Response and Office of Waste Programs Response, Washington, D.C.

Chatters, J. C., H. A. Gard, and P. E. Minthorn, Fiscal Year 1991 Report on Archaeological Surveys of the 100 Areas, Hanford Site, Washington, PNL-8143, Pacific Northwest Laboratory, Richland, Washington.

Dement, F. G., 1988, Radiological Release of the 105-C Pond Using the ARCL Methodology, SD-DD-TI-031, Westinghouse Hanford Company, Richland, Washington.

DeNeal, D. L., 1965, Historical Events--Reactors and Fuels Fabrication, RL-REA-2247, Richland, Washington.

DOE, 1992, Decommissioning of Eight Surplus Production Reactors at the Hanford Site, Richland, Washington, Addendum; Final Environmental Impact Statement, DOE/EIS-0119F, U.S. Department of Energy, Washington, D.C.

DOE, 1987, Disposal of Hanford Defense High-Level, Transuranic, and Tank Wastes, Final Environmental Impact Statement, DOE/EIS-0113, U.S. Department of Energy, Washington, D.C. 
DOE-RL, 1989, Environmental Restoration Field Office Management Plan, DOE/RL 89-29, U.S. Department of Energy - Richland Operations Office, Richland, Washington.

DOE-RL, 1991a, Hanford Site Past Practice Strategy; Draft A, DOE/RL-91-40, U.S. Department of Energy, Richland, Washington.

DOE-RL, 1991b, Hanford Site Waste Management Units Report, Revision 1, DOE/RL-88-30, U.S. Dejartment of Energy, Richland Op:srations Office, Richland, Washington.

DOE-RL, 1992a, Remeäial In'estigation/Feasibility Study Work Plan for 100-BC-1 Operable Unit, Hanford Site, Richland, Washington, DOE/RL 9/J-07, Rev. 0, U.S. Department of Energy, Richland, Washington.

DOE-RL, 1992b, Remedial Investigation/Feasibility Study Work Plan for the 100-BC-5 Operable Unit, Hanford Site, Richland, Washington, DOE/RL-90-08, Rev. 0, U.S. Department of Energy, Richland, Washington.

DOE-RL, 1993, Hanford Site Baseline Risk Assessment Methodology, DOE/RL 91-45, U.S. Department of Energy, Richland, Washington.

Dorian, J. J., and V. R. Richards, 1978, Radiological Characterization of the Retired 100 Areas, UNI-946, United Nuclear Industries, Inc., Richland, Washington.

Ecology, EPA, and DOE-RL, 1990a, Hanford Federal Facility Agreement and Consent Order, Washington State Department of EcJlcgy, Oiympia, Washington, U.S. Environmental Protection Agency, Region X, Seattle, Washington, and U.S. Department of Energy, Richland Operations Office, Richland, Washington.

EPA, 1991, Integrated Risk Information System (IRIS) Database, U.S. Environmental Protection Agency, accessed through National Library of Medicine Toxicology Data Network (TOXNET), Bethesda, Maryland.

EPA, 1988, Guidance for Conducting Remedial Investigations and Feasibility Studies Under CERCLA, Interim Final, EPA/540/G-89/004, U.S. Environmental Protectioni Agency, Office of Solid Waste and Emergency Resporise, Washington, D.C.

EPA, 1986a, Quality Criteria for Water 1986, EPA/440/4-86-001, U.S. Environmental Protection Agency, Office of Water Regulations and Standards, Washington, D.C.

EPA, 1986b, Test Methods for Evaluating Solid Waste (SW-846), Third Edition, U.S. Environmental Protection Agency, Office of Solid Waste and Emergency Response, Washington, D.C. 
EPA, 1992, Health Effects Assessment Summary Tables, FY-1991 Annual, OHEA/ECAO-CIN-821, U.S. Environmental Protection Agency, Office of Emergency and Remedial Response, Washington, D.C.

General Electric, 1963, Hazards Summary Report--Volume 3, Description of the 100-B, 100-C, 100-D, 100-F, and 100-H Production Reactor Plants, HW-74094, General Electric Hanford Atomic Products Operation, Richland, Washington.

Heid, K.R., 1956, Unconfined Underground Radioactive Waste and Contamination 100 Areas, HW-46715, General Electric, Hanford Atomic Products Operation, Richland, Washington.

Hoover, J. D., and T. LeGore, 1991, Characterization and Use of Soil and Groundwater Background for the Hanford Site, WHC-MR-0246, Westinghouse Hanford Company, Richland, Washington.

Jaquish, R. E., and R. W. Bryce (eds.), 1989, Hanford Site Environmental Report for Calendar Year 1988, PNL-6825, Pacific Northwest Laboratory, Richland, Washington.

Koop, W. N., 1964, Radionuclides in an Abandoned Reactor Facility, HW-81300, General Electric Company Hanford Atomic Products Operation, Richland, Washington.

Luey, J., S. S. Koegler, W. L. Kuhn, P. S. Lowery, R. G. Winkelman, 1992, In Situ Vitrification of a Mixed-Waste Contaminated Soil Site: The 116-B-6A Crib at Hanford, PNL-8281, Pacific Northwest Laboratory, Richland, Washington.

Miller, R. L., 1987, Spent Fuel Pool Cleanup and Stabilization, UNI-SA-198, UNC Nuclear Industries, Richland, Washington.

Miller, R. L., and J. M. Steffes, 1987, Radionuclide Inventory and Source Terms for the Surplus Production Reactors at Hanford, UNI-3714, Rev. 1, UNC Nuclear Industries, Richland, Washington.

Miller, R. L., and R. K. Wahlen, 1987, Estimates of Solid Waste Buried in 100 Area Burial Grounds, WHC-EP-0087, Westinghouse Hanford Company, Richland, Washington.

Richards, R. B., 1953, Process Specifications, Reactor Cooling Water Treatment, HW-28505, General Electric Company Hanford Atomic Products Operation, Richland, Washington.

Soldat, J. K., and G. R. Quimby, 1953, Effective Retention Time of the Hanford 107 Reactor Effluent Retention Basins, HW-28830, General Electric Company Hanford Atomic Products Operation, Richland, Washington. 
Stanley, W., and S. S. Verner, 1983, Interim Guidelines and Specifications for Preparing Quality Assurance Project Plans, EPA/600/4-83/004, U.S. Environmental Protection Agency, Office of Exploratory Research, Washington, D.C.

Stenner, R. D., K. H. Cramer, K. A. Higley, S. J. Jette, D. A. Lamar, T. J. McLaughlin, D. R. Sherwood, and N. C. VanHouten, 1988, Hazard Ranking System Evaluation of CERCLA Inactive Waste Sites at Hanford, PNL-6456, Pacific Northwest Laboratory, Richland, Washington.

Stone, W. A., J. M. Thorp, O. P. Gifford, and D. J. Hoitink, 1983, Climatological Summary for the Hanford Area, PNL-4622, Pacific Northwest Laboratory, Richland, Washington.

WHC, 1991, WIDS Database Field Descriptions and Data, WHC-MR-0056, Rev. 1, Westinghouse Hanford Company, Richland, Washington.

WHC, 1990, Environmental Engineering, Technology, and Permitting Function Quality Assurance Program Plan, WHC-EP-0383, Westinghouse Hanford Company, Richland, Washington.

WHC, 1988, Environmental Investigations and Site Characterization Manual, WHC-CM-7-7, et seq., Westinghouse Hanford Company, Richland, Washington. 
DOE/RL-91-07, Rev. 0

APPENDIX A

QUALITY ASSURANCE PROJECT PLAN 


\section{GLOSSARY}

Accuracy: For the purposes of enviionmental investigations, accuracy may be interpreted as the measure of the bias in a system. Sampling accuracy is normally assessed through the evaluation of matrix-spiked samples, reference samples, and split samples.

Audit: For the purposes of environmental investigations, audits are considered to be systematic checks to verify the quality of operation of one or more elements of the total measurement system. In this sense, audits may be of two types: (1) performance audits, in which quantitative data are independently obtained for comparison with data routinely obtained in a measurement system, or (2) system audits, involving a qualitative onsite evaluation of laboratories or other organizational elements of the measurement system for compliance with established quality assurance program and procedure requirements. For environmental investigations at the Hanford Site, performance audit requirements are fulfilled by periodic submittal of blind samples to the primary laboratory, or the analysis of split samples by an independent laboratory. System audit requirements are implemented through the use of standard surveillance procedures.

Bias: Bias represents a systematic error that contributes to the difference between a population mean of a set of measurements and an accepted reference or true value.

Blind Sample: A blind sample refers to any type of sample routed to the primary laboratory for performance audit purposes, relative to a particular sample matrix and analytical method. Blind samples are not specifically identified as such to the laboratory. They may be made from traceable standards, or may consist of sample material spiked with a known concentration of a known compound. See the glossary entry for Audit.

Comparability: For the purposes of environmental investigations, comparability is an expression of the relative confidence with which one data set may be compared with another.

Completeness: For the purposes of environmental investigations, completeness may be interpreted as a measure of the amount of valid data obtained compared to the total data expected under correct normal conditions.

Deviation: For the purposes of environmental investigations, deviation refers to an approved departure from established criteria that may be required as a result of unforeseen field situations or that may be required to correct ambiguities in procedures that may arise in practical applications.

Equipment Blanks: Equipment blanks shall consist of pure deionized, distilled water washed through decontaminated sampling equipment and placed in containers identical to those used for actual field samples. They are used to verify the adequacy of sampling equipment decontamination procedures, and are normally collected at the same frequency as field duplicate samples. 
Field Duplicate Sample: Field duplicate samples are samples retrieved from the same sampling location using the same equipment and sampling technique, placed in separate, identically prepared and preserved containers, and analyzed independently. Fieid duplicate samples are generally used to evaluate the reproducibility of analytical data and the field variability. Field duplicates are normally collected with each analytical batch or every 20 samples, whichever is greater.

Matrix-Spiked Samples: Matrix-spiked samples are a type of laboratory quality control sample. They are prepared by splitting a sample received from the field into two homogenous aliquots (i.e., replicate samples) and adding a known quantity of a representative analyte of interest to one aliquot in order to calculate the percentage of recovery of that analyte.

Nonconformance: A nonconformance is a deficiency in the characteristic, documentation, or procedure that renders the quality of material, equipment, services, or activities unacceptable or indeterminate. When the deficiency is of a minor nature, does not effect a permanent or significant change in quality if it is not corrected, and can be brought into conformance with immediate corrective action, it shall not be categorized as a nonconformance. If the nature of the condition is such that it cannot be immediately and satisfactorily corrected, however, it shall be documented in compliance with approved procedures and brought to the attention of management for disposition and appropriate corrective action.

Precision: Precision is a measure of the repeatability or reproducibility of specific measurements under a given set of conditions. The relative percent difference (RPD) is used to assess the precision of the sampling and analytical method. RPD is a quantitative measure of the variability. Specifically, precision is a quantitative measure of the variability of a group of measurements compared to their average value. Precision is normally expressed in terms of standard deviation, but may also be expressed as the coefficient of variation (i.e., relative standard deviation) and range (i.e., maximum value minus minimum value). Precision is assessed by means of duplicate/replicate sample analysis.

Quality Assurance: For the purposes of environmental investigations, QA refers to the total integrated quality planning, quality control, quality assessment and corrective action activities that collectively ensure that the data from monitoring and analysis meets all end user requirements and/or the intended end use of the data.

Quality Assurance Project Plan: The QAPjP is an orderly assembly of management policies, project objectives, methods and procedures that defines how data of known quality will be produced for a particular project or investigation.

Quality Control: For the purposes of environmental investigations, QC refers to the routine application of procedures and defined methods to the performance of sampling, measurement and analytical processes.

Range: Range refers to the difference between the largest and smallest reported values in a sample, and is a statistic for describing the spread in a set of data. 
Reference Samples: Reference samples are a type of laboratory quality control sample prepared from an independent, traceable standard at a concentration other than that used for analytical equipment calibration, but within the calibration range. Such reference samples are required for selected analytical methods, and are normally analyzed at a frequency of one per analytical batch.

Replicate Sample: Replicate samples are two aliquots removed from the same sample container in the laboratory and analyzed independently.

Representativeness: For the purposes of environmental investigations, representativeness may be interpreted as the degree to which data accurately and precisely represent a characteristic of a population parameter, variations at a sampling point, or an environmental condition. Representativeness is a qualitative parameter that is most concerned with the proper design of a sampling program.

Split Sample: A split sample is produced through homogenizing a field sample and separating the sample material into two equal aliquots. Field split samples are usually routed to separate laboratories for independent analysis, generally for purposes of auditing the performance of the primary laboratory relative to a particular sample matrix and analytical method. See the glossary entry for Audit. In the laboratory, samples are generally split to create matrix-spiked samples (see the glossary entry).

VOA Trip Blanks: Volatile organics analysis (VOA) trip blanks are a type of field quality control sample, consisting of pure deionized distilled water in a clean, sealed sample container, accompanying each batch of containers shipped to the sampling site and returned unopened to the laboratory. Trip blanks are used to identify contamination originating from container preparation methods, shipment, handling, storage, site conditions or the analytical laboratory.

Validation: For the purposes of environmental investigations, validation refers to a systematic process of reviewing data against a set of criteria to provide assurance that the data are acceptable for their intended use. Validation methods may include review of verification activities, editing, screening, cross-checking or technical review.

Verification: For the purposes of environmental investigations, verification refers to the process of determining whether procedures, processes, data or documentation conform to specified requirements. Verification activities may include inspections, audits, surveillance or technical review. 
DOE/RL-91-07, Rev. 0 


\section{CONTENTS}

1.0 PROJECT DESCRIPTION $\ldots \ldots \ldots \ldots \ldots \ldots \ldots \ldots \ldots \ldots$ A-1

1.1 PROJECT OBJECTIVE $\ldots \ldots \ldots \ldots \ldots \ldots \ldots \ldots$ A-1

1.2 BACKGROUND . . . . . . . . . . . . . . A A-1

1.3 SCOPE AND RELATIONSHIP TO WHC QA PROGRAM $\ldots \ldots \ldots$ A-1

1.4 PROJECT ACTIVITIES $\ldots \ldots \ldots \ldots \ldots \ldots \ldots \ldots \ldots$ A-2

2.0 PROJECT ORGANIZATION AND RESPONSIBILITIES $\ldots \ldots \ldots \ldots \ldots$ A-2

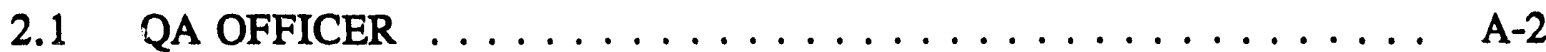

2.2 TECHNICAL LEAD $\ldots \ldots \ldots \ldots \ldots \ldots \ldots \ldots \ldots \ldots \ldots$ A-2

2.3 ANALYTICAL LABORATORIES $\ldots \ldots \ldots \ldots \ldots \ldots \ldots$ A-3

2.4 OTHER SUPPORT CONTRACTORS $\ldots \ldots \ldots \ldots \ldots \ldots$ A-3

3.0 QUALITY ASSURANCE OBJECTIVES FOR MEASUREMENTS $\ldots \ldots \ldots$ A-4

4.0 SAMPLING PROCEDURES $\ldots \ldots \ldots \ldots \ldots \ldots \ldots \ldots$ A-5

4.1 APPROVALS AND CONTROL $\ldots \ldots \ldots \ldots \ldots \ldots \ldots$ A-5

4.1.1 WHC Procedures $\ldots \ldots \ldots \ldots \ldots \ldots \ldots$ A-5

4.1.2 Participant Contractor/Subcontractor Procedures . . . . . . A A-5

4.2 SAMPLING PROCEDURES $\ldots \ldots \ldots \ldots \ldots \ldots \ldots \ldots$ A-6

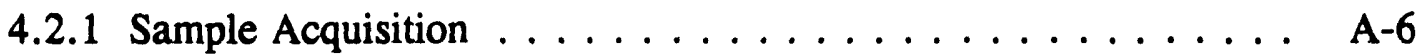

4.2.2 Sample Container Selection . . . . . . . . . . . A A-6

4.3 OTHER INVESTIGATIVE AND SUPPORTING

PROCEDURES $\ldots \ldots \ldots \ldots \ldots \ldots \ldots \ldots \ldots$ A-6

4.4 PROCEDURE CHANGES $\ldots \ldots \ldots \ldots \ldots \ldots \ldots \ldots$ A-6

5.0 SAMPLE CUSTODY $\ldots \ldots \ldots \ldots \ldots \ldots \ldots \ldots \ldots$ A-7

6.0 CALIBRATION PROCEDURES $\ldots \ldots \ldots \ldots \ldots \ldots \ldots \ldots$ A-7

7.0 ANALYTICAL PROCEDURES $\ldots \ldots \ldots \ldots \ldots \ldots \ldots \ldots$ A-7

8.0 DATA REDUCTION, VALIDATION, AND REPORTING $\ldots \ldots \ldots \ldots$ A-8

8.1 DATA REDUCTION AND DATA PACKAGE PREPARATION $\ldots \ldots \ldots \ldots \ldots \ldots \ldots \ldots \ldots$. . . . . . . .

8.2 VALIDATION . . . . . . . . . . . . . . . . A-9

8.3 FINAL REVIEW AND RECORDS MANAGEMENT CONSIDERATIONS . . . . . . . . . . . . . . . A-9

8.4 REQUIREMENTS FOR HANDLING UNACCEPTABLE OR SUSPECT DATA $\ldots \ldots \ldots \ldots \ldots \ldots \ldots \ldots$ A-9

9.0 IN PROCESS QUALITY CONTROL $\ldots \ldots \ldots \ldots \ldots \ldots \ldots$. . . . . . A $\ldots$

10.0 PERFORMANCE AND SYSTEM AUDITS $\ldots \ldots \ldots \ldots \ldots \ldots \ldots$ A-11 
CONTENTS (cont.)

11.0 PREVENTIVE MAINTENANCE $\ldots \ldots \ldots \ldots \ldots \ldots \ldots \ldots \ldots$ A-12

12.0 DATA ASSESSMENT PROCEDURES $\ldots \ldots \ldots \ldots \ldots \ldots \ldots \ldots$ A-12

13.0 CORRECTIVE ACTION $\ldots \ldots \ldots \ldots \ldots \ldots \ldots \ldots \ldots \ldots \ldots$ A-13

13.1 GENERAL REQUIREMENTS FOR CORRECTIVE ACTION $\ldots \ldots$ A-13

13.2 CORRECTIVE ACTION REQUIREMENTS RELATED TO

CALIBRATION ERRORS . . . . . . . . . . . . A A-13

13.3 CORRECTIVE ACTION REQUIREMENTS RELATED TO

PURCHASED MATERIALS, ITEMS, OR EQUIPMENT $\ldots \ldots \ldots$ A-13

14.0 QUALITY ASSURANCE REPORTS $\ldots \ldots \ldots \ldots \ldots \ldots \ldots \ldots$ A-13

15.0 REFERENCES $\ldots \ldots \ldots \ldots \ldots \ldots \ldots \ldots \ldots \ldots \ldots \ldots$ A-14

TABLES:

QAPjP-1 Analytical Methods and Parameters, Detection Limits, and

Precision and Accuracy Requirements for the

100-BC-2 Source Operable Unit . . . . . . . . . . . . . . . . AT-1

QAPjP-2 Sampling and Investigative Procedures for Limited Investigations

in the $100-\mathrm{BC}-2$ Source Operable Unit $\ldots \ldots \ldots \ldots \ldots \ldots$ AT-10 


\subsection{PROJECT DESCRIPTION}

\subsection{OBJECTIVE}

The objectives of the environmental investigations in the 100-BC-2 operable unit are defined in Section 1.1 of the work plan. Analytical data resulting from the samplins portion of the investigation will be validated and evaluated to determine the most feasible options for additional investigation, remediation, or closure.

\subsection{BACKGROUND}

The 100-BC-2 operable unit is located within the 100 Area of the Hanford Site, shown in Figure 1-1 of the work plan. Detailed background information regarding the history and present use of the unit is provided in Chapter 2 of the work plan.

\subsection{SCOPE AND RELATIONSHIP TO WHC QA PROGRAM}

This quality assurance project plan (QAPjP) applies specifically to the field activities and laboratory analyses performed as part of the limited field investigation (LFI) for the $100-\mathrm{BC}-2$ operable unit. It is prepared specifically for this phase of investigation, and is prepared in compliance with the requirements of the Westinghouse Hanford Company (WHC) Environmental Engineering, Technology, and Permitting Function Quality Assurance Program Plan (WHC 1990a). The QA program plan implements the overall QA program requirements defined by the Quality Assurance Manual (WHC 1988a), as applicable to environmental investigations, while accommodating the specific requirements for project plan format and content agreed on in the Hanford Federal Facility Agreement and Consent Order (Ecology et al. 1990). It contains a matrix of procedural resources from the QA manual (WHC 1988a), the Environmental Investigations and Site Characterization Manual (WHC 1988b), and other sources that have been drawn on to support this QAPjP.

A preliminary discussion of field work (i.e., location of sampling) is provided in Chapter 5 of the work plan. Final sampling locations, required sampling intervals, sample quantities, sampling frequency, and schedules for all technical activities addressed in this investigation shall be defined by investigation-specific descriptions of work prepared in compliance with Environmental Investigation Instruction (EII) 1.14, "Preparation of Descriptions of Work" (WHC 1988b). The description of work satisfies the requirements of the field sampling plan.

Distribution and revision control of the work plan and the QAPJP will be performed in compliance with Quality Requirement (QR) 6.0, "Document Control" and other applicable procedures as identified in the QA program index (QAPI) included in the QA program plan (WHC 1990a). 
Interim changes to this QAPjP or the work plan shall be documented, reviewed, and approved as required by Section 6.6 of EII 1.9, "Work Plan Review" (WHC 1988b), and shall be documented in monthly unit managers' meeting minutes. QAPjP distribution shall routinely include all review/approval personnel indicated on the title page of the document and all other individuals designated by the WHC technical lead. All plans and procedures referenced in the QAPjP are available for regulatory review on request at the direction of the technical lead.

\subsection{PROJECT ACTIVITIES}

Investigations to be conducted in the 100-BC-2 operable unit include source geological and vadose zone investigations, as well as an investigation made up of other miscellaneous tasks. More detailed discussions of individual tasks are contained in Chapter 5 of the work plan.

\subsection{PROJECT ORGANIZATION AND RESPONSIBILITIES}

Chapter 7 of the $100-\mathrm{BC}-1$ operable unit work plan can be referenced for the applicable project organization structure.

\subsection{QA OFFICER}

The QA Officer is responsible for coordination/oversight of performance to the QAPjP requirements by means of internal auditing and surveillance techniques. The QA Officer has the necessary organizational independence and authority to identify conditions adverse to quality and to inform the technical lead of needed corrective action.

\subsection{TECHINICAL LEAD}

The Environmental Restoration Engineering Function of WHC has primary responsibility for conducting this investigation. Organizational charts, responsibility descriptions, and individual WHC field team descriptions are addressed in Chapter 7 of the 100-BC-1 work plan and in the governing project procedures identified herein.

External participant contractors or subcontractors shall be evaluated and selected for certain portions of task activities at the direction of the technical lead in compliance with $Q R$ 4.0, "Procurement Document Control", QR 7.0, "Control of Purchased Items and Services" (WHC 1988a), and other procedures as identified under criteria 4 and 7 of the QAPI included in QA program plan (WHC 1990a). Major participant contractor and subcontractor resources are discussed in Chapter 7 of the 100-BC 1 work plan. All contractor or 
subcontractor plans and procedures shall be approved before their use, and shall be available for regulatory review after WHC approval.

\subsection{ANALYTICAL LABORATORIES}

The WHC field sampling team will be responsible for screening all samples for radioactivity in compliance with EII 2.3, "Administration of Radiation Surveys to Support Environmental Characterization Work on the Hanford Site" (WHC 1988b).

All samples shall be screened for radiological activity prior to shipment to the analytical laboratory. If the total activity of the sample is $\geq 200 \mathrm{pCi} / \mathrm{g}$ or if the alpha activity of the sample is $\geq 60 \mathrm{pCi} / \mathrm{g}$, samples shall be packaged and shipped in compliance with Section 6.3 of EII 5.11, "Sample Packaging and Shipping" (WHC 1988b) and routed to a WHC or Hanford Site participant contractor or subcontractor laboratory equipped and qualified to handle the analysis of radioactive samples. Samples that do not exceed either of the above criteria may be routed to any approved participant contractor or subcontractor analytical laboratory.

All analyses shall be coordinated through Hanford Analytical Services Management (HASM) and shall be performed in compliance with WHC-approved laboratory QA plans and analytical procedures; all analytical laboratories shall be subject to the surveillance controls described by Quality Instruction (QI) 10.4 "Surveillance" (WHC 1988a). For subcontractors or participant contractors, applicable quality requirements shall be invoked as part of the approved procurement documentation or work order; see Sections 3 and 4.1.2 of this QAPjP. Services of alternate qualified laboratories shall be procured for radioactive sample analysis if onsite laboratory capacity is not available for the performance of split sample analysis at the technical lead's discretion. If such an option is selected, the laboratory shall provide objective evidence of appropriate U.S. Nuclear Regulatory Commission or state radioactive materials handling licenses. The laboratory shall submit its QA plan and applicable analytical procedures for WHC approval prior to their use, as noted in Section 4.1.2.

\subsection{OTHER SUPPORT CONTRACTORS}

Procurement of all other field services and supporting items, materials, or equipment shall comply with standard WHC procurement procedures as discussed in Sections 2.2 and 4.1 of this QAPjP. All work shall comply with WHC-approved QA plans/procedures, and is subject to the controls of QI 10.4, "Surveillance" (WHC 1988a). Applicable quality requirements shall be invoked as part of the approved procurement documentation or work order as noted in Section 4.1. 


\subsection{QUALITY ASSURANCE OBJECTIVES FOR MEASUREMENTS}

The rationale for establishing data quality objectives (DQO) and data needs for this investigation is presented in Sections 4.1.1 and 4.1.2 of the work plan.

All analytical parameters that have been selected for this investigation are included in Table QAPjP-1, cross-referenced to analytical method requirements and minimum detection or quantitation limit values and minimum acceptable ranges for precision and accuracy, in both soil and water matrices.

The table covers a full suite of Comprehensive Environmental Response, Compensation, and Liability Act of 1980 target compound list/target analyte list, but for this investigation, a reduced analyte list is being used as discussed in Chapter 3 of the work plan. The specific methods used are identified in Table QAPjP-1. Precision and accuracy requirements are those specified in Table QAPjP-1 which are based on the requirements from Contract Laboratory Program Statement of Work for Inorganics Analysis (EPA 1991a) and Contract Laboratory Program Statement of Work for Organic Analysis (EPA 1991b). For non-CLP parameters (EPA 1986), method detection limit, practical quantitation limit, and precision and accuracy ranges are provided that shall be considered minimum values that can be reliably achieved by analytical laboratories under routine conditions.

The requirements of Table QAPjP-1 shall be considered a minimum performance standard, and shall be incorporated into the agreements for services established with individual WHC, participant contractor, or subcontractor analytical laboratories. Any modification of Table QAPjP-1 requirements shall be justified by the requestor, shall be considered a formal modification of this QAPjP, and is subject to regulatory review and approval.

Goals for data representativeness will be addressed qualitatively by the specification of sampling depths and intervals, and the use of standardized techniques discussed in the description of work prepared for this investigation, as previously described in Section 1.3 of this QAPjP. Section 4.1 and Chapter 5 of the work plan can be referenced for a more detailed discussion of the DQO and field activities. Sampling locations will be specified in the description of work or work orders issued to the subcontractors or participating contractors responsible for conducting sampling activities. Objectives for the completeness of this investigation shall require that contractually or procedurally established requirements for precision and accuracy be met for at least $90 \%$ of the total number of requested determinations. Failure to meet this criterion shall be documented and evaluated in the validation process described in Chapter 8 of this QAPJP; corrective action shall be taken as warranted, as described in Chapter 13. Approved analytical procedures shall require the use of the reporting techniques and units specified in the U.S. Environmental Protection Agency (EPA) reference methods specified in Table QAPjP-1 to facilitate the comparability of data sets in terms of precision and accuracy. 


\subsection{S. AMPLING PROCEDURES}

\subsection{APPROVALS AND CONTROL}

\subsubsection{WHC Procedures}

The WHC procedures cited in this QAPjP have been selected from the QAPI included in the QA program plan (WHC 1990a). Selected procedures include EII from the Environmental Investigations anc ite Characterization Manual (WHC 1988a) (the companion document is Opeioutional Health Physics Practices Manual [WHC 1988c]) and QR and QI from the Quality Assurance Manual (WHC 1988a). Procedure approval, revision, and distribution control requirements applicable to EII are addressed in EII 1.2, "Preparation and Revision of Environmental Investigations Instructions" (WHC 1988b); requirements applicable to $Q I$ and $Q R$ are addressed in $Q R$ 5.0, "Instructions, Procedures, and Drawings" (WHC 1988a). Other procedures applicable to the preparation, review, approval, and revision of other WHC organizations shall be as defined in the various procedures and manuals identified in the QAPI under criteria 5 and 6 . All procedures are available for regulatory review on request, at the direction of the WHC technical lead.

\subsubsection{Participant Contractor/Subcontractor Procedures}

As previously noted in Section 2.2, participant contractor/subcontractor services shall be procured under QR 4.0, "Procurement Documeni Control", QR 7.0, "Control of Purchased Items and Services" (WHC 1988a), and other procedures as identified under criteria 4 and 7 of the QAPI included in the QA program plan (WHC 1990a). Submittal requirements of procedures for WHC review and approval before use shall be included in the procurement document or work order, as applicable, when such services require procedural controls. Analytical laboratories shall be required to submit the current version of their internal QA program plans, in addition to analytical procedures. All analytical laboratory plans and procedures shall be reviewed and approved before use by qualified personnel from the WHC ana'ytical laboratories organization, or other qualified persnnnel, as directed by the technical lead. All reviewers shall be qualified under the requirements of EII 1.7, "Indoctrination, Training, and Qualification" (WHC 1988b). All participant contractor or subcontractor procedures, plans/manuals shall be retained as project records in compliance with Document Control and Records Management Manual (WHC 1990d, Section 9). All such documents are available for regulatory review on request, at the direction of the WHC technical lead. 


\subsection{SAMPLING PROCEDURES}

\subsubsection{Sample Acquisition}

Soil and sludge sampling shall be performed in accordance with EII 5.2, "Soil and Sediment Sampling" (WHC 1988b). All drilling activities shall be in compliance with EII 6.7, "Resource Protection Well and Test Borehole Drilling" (WHC 1988b). All boreholes shall be logged in compliance with EII 9.1, "Geologic Logging" (WHC 1988b). Sampling procedure applicability to individual project tasks is shown in Table QAPjP-2. Sampling depths and intervals will be identified in the description of work prepared for this investigation as noted in Section 1.3 of this QAPjP. Sample locations will be detailed in the descriptions of work or work orders issued to the responsible subcontractors or participating contractors. Documentation requirements are defined within individual EII. Samples will be identified by a unique number as described in EII 5.10 "Sample Identification and Data Entry into HEIS Database" (WHC 1988b).

\subsubsection{Sample Container Selection}

Sample container types, preservation requirements, preparation requirements, and special handling requirements are defined in EII 5.2, "Soil and Sediment Sampling" (WHC 1988b); and EII 5.11, "Sample Packaging and Shipping" (WHC 1988b). Final requirements for sample container types, preservation requirements, etc., will be specified by HASM in the sample authorization form for the pioject.

\subsection{OTHER INVESTIGATIVE AND SUPPORTING PROCEDURES}

Other procedures that will be required, if the task is required, in this phase of the investigation are identified in Table QAPjP-2 referenced to individual tasks as applicable. Other procedures not listed on Table QAPjP-2 that may be required will be documented in the description of work. At this time, no such procedures are anticipated. Documentation requirements shall be addressed within individual procedures/the data management plan, as appropriate. Analytical procedures required for Phase I of this investigation are listed in Table QAPjP-1. All computer software models that may be developed for this investigation shall be documented and verified in compliance with the procedures identified under criterion 3 of the QAPI included in the QA program plan (WHC 1990a). At this time, no such models are anticipated.

\subsection{PROCEDURE CHANGES}

Should deviations from established EII be required to accommodate unforeseen field situations, they may be authorized by the field team leader in accordance with the requirements specified in EII 1.4, "Deviation from Environmental Investigations instructions" (WHC 1988b). Documentation, review, and disposition of instruction change authorization 
forms shall be defined by EII 1.4. Other types of procedure change requests shall be documented as required by QR 6.0, "Document Control" (WHC 1988a) or other procedures as identified under criterion 6 of the QAPI included in the QA program plan (WHC 1990a).

\subsection{SAMPLE CUSTODY}

Samples obtained during the course of this investigation shall be controlled as required by EII 5.1, "Chain of Custody" (WHC 1988b), from the point of origin to the analytical laboratory. Laboratory chain-of-custody procedures shall be reviewed and approved in compliance with the requirements of Section 4.1 of this QAPjP, and shall ensure the maintenance of sample integrity and identification throughout the analytical process. At the direction of the technical lead, requirements for the return of residual sample materials after completion of analysis shall be defined in accordance with procedures described in the procurement documentation to subcontractor or participant contractor laboratories. Chain-ofcustody forms shall be initiated for returned residual samples as required by the approved procedures applicable within the laboratory. All analytical results shall be controlled as permanent project quality records as required by WHC (1991d, Section 9).

\subsection{CALIBRATION PROCEDURES}

Calibration of all WHC measuring and test equipment, whether in existing inventory or purchased for this investigation, shall be controlled per QR 12.0, "Control of Measuring and Test Equipment" (WHC 1988a), other procedures as identified under criterion 12 of the QAPI included in the QA program plan (WHC 1990a), and/or specific requirements incorporated in the text of investigation-specific descriptions of work prepared in compliance with EII 1.14, Preparation of Descriptions of Work. Routine operational checks for WHC field equipment shall be as defined within applicable EII or procedures; similar information shall be provided in WHC-approved participant contractor or subcontractor procedures or included in the text of applicable descriptions of work as indicated above. All calibration requirements applicable to analytical laboratory equipment shall be as defined by standard analytical methods used, subject to WHC review and acceptance.

\subsection{ANALYTICAL PROCEDURES}

Analytical methods that have been selected for this investigation are listed in Table QAPjP-1, cross-referenced to the parameters of interest and the maximum detection or quantitation limit values and maximum acceptable ranges for precision and accuracy for both soil and water matrices. Where EPA Contract Laboratory Procedures (CLP) methods are 
specified, the contract required detection limit (CRDL) for inorganic parameters, the contract required quantitation limit (CRQL) for organic parameters, and the maximum precision and accuracy ranges specified for each parameter by the appropriate CLP statements of work apply without modification (see EPA 1991a and 1991b). For non-CLP parameters, CRQL, and precision and accuracy ranges are provided that shall be considered maximum values that can be reliably achieved by analytical laboratories. To facilitate the comparability of data sets in terms of precision and accuracy, all analytical data shall be reported in the standard units specified in the applicable reference method. The reporting requirements so defined and the applicable requirements of Table QAPjP-1 shall be considered minimum performance standards that shall be incorporated into the agreements for services established with individual WHC, participant contractor, or subcontractor analytical laboratories. As previously noted in Chapter 3, any modification of Table QAPjP-1 requirements shall be justified $t ;$ the requestor, shall be considered a formal modification of this QAPjP, and is subject to regulatory review and approval.

All analytical procedures approved for use in this investigation shall require the use of the standard units specified by the analytical methods referenced in Table QAPjP-1 to facilitate the comparability of data sets in terms of precision and accuracy. All approved procedures shall be retained in the project quality records and shall be available for review on request.

\subsection{DATA REDUCTION, VALIDATION, AND REPORTING}

\subsection{DATA REDUCTION AND DATA PACKAGE PREPARATION}

Analytical laboratories shall be responsible for preparing a report summarizing the results of analyses and for preparing a detailed data package that includes identifying samples, sampling and analysis dates, raw analytical data, reduced data, data outliers, recovery percentages, quality control $(\mathrm{QC})$ check data, equipment calibration data, supporting chromatogram or spectrograms, and documentation of any nonconformances affecting the measurement system in use during the analysis of the particular group of samples. Data reduction schemes shall be contained within individual laboratory analytical methods, procedures/QA manuals, submitted for WHC review and acceptance as discussed in Section 4.1. The completed data package shall be reviewed and approved by the analytical laboratory's QA manager, or other authorized person (or field team leader for field screening type analysis) before its submittal to the WHC technical lead. Completed data packages shall be submitted to HASM for verification, tracking, and data validation functions. The requirements of this section shall be included in procurement documentation or work orders, as appropriate, to comply with the standard WHC procurement control procedures noted in Section 4.1. 
DOE/RL-91-07, Rev. 0

\subsection{VALIDATION}

Validation of the completed data package will be performed by qualified WHC personnel or by a qualified independent participant contractor. Subcontracted validation responsibilities shall be defined in procurement documentation or work orders as appropriate. All validation shall be performed in compliance with the Sample Management Administration Manual (WHC 1990b), Section 2.2, for organics analyses, Section 2.1 for inorganics analyses, and Sections 2.3 and 2.4 for radionuclide analysis. No validation is proposed for the 100-BC-2 operable unit LFI samples.

\subsection{FINAL REVIEW AND RECORDS MANAGEMENT CONSIDERATIONS}

Verification and validation reports and supporting analytical data packages shall be subject to a final technical review by a qualified reviewer at the direction of the WHC technical lead, before their submittal to regulatory agencies; prior to entry into the Hanford Environmental Information System (HEIS) in compliance with EII 14.1, "Analytical Laboratory Data Management, " (WHC 1988b); or before inclusion in reports or technical memoranda. Verification and validation reports, data packages, and review comments shall be retained as permanent project quality records in compliance with Document Control and Records Management Manual (WHC 1990d, Section 9).

\subsection{REQUIREMENTS FOR HANDLING UNACCEPTABLE OR SUSPECT DATA}

The analytical data flow and data management process is described in detail in EII 14.1, "Analytical Laboratory Data Management" (WHC 1988b). Data errors or procedural discrepancies related to laboratory analytical processes shall prompt data qualification by the validator, requests for reanalysis, or other appropriate corrective action by the responsible laboratory as required by governing HASM or approved subcontractor data validation procedures. If sample holding time requirements are compromised, insufficient sample material is available for reanalysis, or if any other condition prevents compliance with governing analytical methods and data validation protocols, the situation shall be formally documented as a nonconformance in compliance with $Q R$ 15.0, "Control of Nonconforming Items" (WHC 1988a). If problems are observed with validated data, either as part of the data assessment process described in Section 12 of this QAPjP or if separately observed by any of the operable unit managers, the data shall be documented as a nonconformance and corrective action initiated as previously noted; if the data have been entered in the HEIS, the HEIS Data Custodian shall be immediately notified so that the data may be flagged (in compliance with EII 14.1 [WHC 1988b] and the HEIS User's Manual [WHC 1990c]) as suspect, pending resolution of the nonconforming condition and completion of all required corrective actions.

\subsection{IN PROCESS QUALITY CONTROL}

All analytical samples shall be subject to in-process QC measures in both the field and laboratory. Unless otherwise specified in the approved statements of work or work orders

WP A-9 
for sampling activities, or in applicable EII, the following minimum field quality control requirements shall apply. These requirements are adapted from Test Methods for Evaluating Solid Waste (EPA 1986), as modified by the proposed rule changes included in the Federal Register, 1989, Volume 54, No. 13, pp 3212-3228, and 1990, Volume 55, No. 27, pp 4440-4445.

- Field duplicate samples. For sampling activity under an individual sampling subtask, a minimum of $5 \%$ of the total collected samples shall be duplicated, or one duplicate shall be collected for every 20 samples, whichever is greater. Duplicate samples shall be retrieved from the same sampling location using the same equipment and sampling technique, and shall be placed into two identically prepared and preserved containers. All field duplicates shall be analyzed independently to provide an indication of field variability and analytical reproducibility.

$\bullet$ Split samples. Upon specific WHC or regulator request, and at the technical lead's direction, field or field duplicate samples may be split in the field and sent to an alternative laboratory as a performance audit of the primary laboratory. The number and frequency of split samples will be specified in the description of work.

- $\quad$ Blind samples. At the technical lead's discretion, blind reference samples may be introduced into any sampling round as a QC check of the primary laboratory.

- Equipment rinseate blanks. Equipment blanks shall consist of purified water (deionized or distilled) washed through decontaminated sampling equipment and placed in containers identical to those used for actual field samples. Equipment blanks are used to verify the adequacy of sampling equipment decontamination procedures, and shall be collected at the same frequency as field duplicate samples where applicable.

- Volatile organic analysis (VOA) trip blanks. VOA trip blanks consist of purified water (deionized or distilled) for water samples and silica sand for soil samples, added to one clean sample container, accompanying each batch (cooler) of containers shipped to the sampling facility. Trip blanks shall be returned unopened to the laboratory, and are prepared as a check on possible contamination originating from container preparation methods, shipment, handling, storage or site conditions. The trip blank shall be analyzed for volatile organic compounds only. In compliance with standard WHC procurement procedures, requirements for trip blank preparation shall be included in procurement documents of work orders to the sample container supplier/preparer.

Unless otherwise specified in WHC-approved analytical methods, internal QC checks performed by analytical laboratories shall meet the following minimum requirements. 
- Matrix-spike/matrix-spike duplicate samples. Matrix-spiked samples require the addition of a known quantity of a representative analyte of interest to the sample as a measure of recovery percentage and as a test of analytical precision. Replicate samples are separate aliquots removed from the same sample container in the laboratory. Spike compound selection, quantities, and concentrations shall be described in the analytical procedures submitted for WHC review and acceptance. One sample shall be spiked per analytical batch, or once every 20 samples, whichever is more frequent.

- $\quad$ OC reference samples. A QC reference sample shall be prepared from an independent standard at a concentration other than that used for calibration, but within the calibration range. Reference samples are required for selected analytical methods as an independent check on analytical technique and methodology, and shall be run with every analytical batch, or every 20 samples, whichever is more frequent.

Other requirements specific to laboratory analytical equipment calibration are included in Chapter 6 of this QAPjP. All field screening instruments employed will be described in the description of work. For field screening gas chromatography (GC) analysis, at least one duplicate sample per shift shall be routed to a qualified laboratory as an overcheck on the proper use and functioning of field GC procedures and equipment. Duplicates shall be selected, whenever possible, from samples in which significant readings have been observed during field analysis. The minimum requirements of this section shall be invoked in procurement documents or work orders in compliance with standard WHC procedures as noted in Section 4.1 of this QAPjP.

\subsection{PERFORMANCE AND SYSTEM AUDITS}

Performance, system, and program audits are scheduled to begin early in the execution of this work plan and continue through work plan completion. Collectively, the audits address quality-affecting activities that include, but are not limited to, measurement system accuracy, intramural and extramural analytical laboratory services, field activities, and data collection, processing, validation, and management.

Performance audits of the accuracy of the total measurement system are implemented in accordance with EII 1.12 "Performance Audits" (WHC 1988b). System audit requirements are implemented in accordance with QI 10.4, "Surveillance" (WHC 1988a). Surveillances will be performed regularly throughout the course of the work plan activities. Additional performance and system "surveillances" may be scheduled as a consequence of corrective action requirements, or may be performed on request. All quality-affecting activities are subject to surveillance.

Inter-operable unit activities will also be evaluated as part of routine environmental restoration program-wide QA audits under the requirements of WHC (1988a). Program 
audits shall be conducted in accordance with QR 18.0, "Audits," QI 18.1, "Audit Programming and Scheduling," and QI 18.2, "Planning, Performing, Reporting, and Followup of Quality Audits" by auditors qualified in accordance with QI 2.5, "Qualification of Quality Assurance Personnel" (WHC 1988a).

\subsection{PREVENTIVE MAINTENANCE}

Measurement and testing equipment used in the field and laboratories that directly affect the quality of the field and analytical data shall be subject to preventive maintenance measures that ensure minimization of measurement system downtime and corresponding schedule delays. Laboratories shall be responsible for performing or managing the maintenance of their analytical equipment. Maintenance requirements, spare parts lists and instructions shall be included in individual laboratory QA plans, subject to WHC review and acceptance as noted in Sections 2.1, 2.2, and 4.1.2 of this QAPjP. When samples are analyzed using EPA reference methods, the preventive maintenance requirements for laboratory analytical equipment are as defined in the procured laboratory's QA plan(s). WHC field equipment shall be drawn from inventories subject to standard preventive maintenance and calibration procedures as noted under criterion 12 of the QAPI included in the QA program plan (WHC 1990a). Any field procedures submitted for WHC acceptance by participant contractors or subcontractors shall contain, as appropriate, provisions for preventive maintenance schedules and spare parts lists to ensure minimization of equipment downtime.

\subsection{DATA ASSESSMENT PROCEDURES}

All analytical data shall be compiled, reduced, and reviewed by the laboratory prior to presentation to HASM or subcontractor personnel for validation as described in Section 8 of this QAPjP. Assessment of the validated data will follow the general guidelines established in Section 5.1.10 of the work plan; depending on the distribution and statistical characteristics of the validated data and other unit- or area-specific considerations, various statistical/probabilistic techniques may be selected for use in the process of data comparison or analysis. The selection of any such methodology shall be subject to the acceptance and authorization of the WHC technical lead. Methods shall be documented, signed, dated, retained as project records in compliance with Document Control and Records Management Manual (WHC 1990d, Section 9), and, as appropriate, considered in the risk assessment and field report preparation tasks described in Sections 5.1.11 and 5.1.13 of the work plan. 


\subsection{CORRECTIVE ACTION}

\subsection{GENERAL REQUTREMENTS FOR CORRECTIVE ACTTON}

Corrective action requests shall be documented and processed as required by QR 16.0, "Corrective Action" (WHC 1988a). Corrective action requests prepared under QR 16.0 requirements shall identify the affected requirement, the probable cause of the deviation, any data that may have been affected by the deviation, and the corrective action required both to resolve the immediate situation and to reduce or preclude its recurrence. Corrections of plans or procedures related to the overall measurement system that do not constitute nonconformances, but may be required as a result of data validation, data assessment, or routine review processes, shall be resolved as required by their governing procedures or shall be referred to the WHC technical lead for resolution and appropriate management action. All documentation related to surveillances, audits, and corrective action shall be maintained in compliance with EII 1.6, "Records Management" (WHC 1988a) and routed to the project quality records on completion or closure for retention in compliance with Section 9 of the records management manual (WHC 1990d), and shall be made available for operable unit manager review on request through the WHC technical lead.

\subsection{CORRECTIVE ACTION REQUIREMENTS RELATED TO CALIBRATION ERRORS}

Field measuring and test equipment found to be out of calibration shall be documented in compliance with QR 12.0, "Control of Measuring and Test Equipment" (WHC 1988a). Measuring devices shall be tagged, removed from service, and segregated pending resolution of the condition. Calibration errors related to laboratory analytical processes that may be observed in the data validation activities described in Chapter 8 shall prompt requests appropriate corrective action.

\subsection{CORRECTIVE ACTION REQUIREMENTS RELATED TO PURCHASED MATERIALS, ITEMS, OR EQUIPMENT}

Purchased materials, items, and equipment found to be out of compliance with their governing procurement specifications shall be documented as a nonconformance in compliance with QR 15.0, "Control of Nonconforming Items" (WHC 1988a). Nonconforming items shall be tagged and segregated pending resolution of the nonconformance.

\subsection{QUALITY ASSURANCE REPORTS}

Project activities shall be regularly assessed by performance and system audits, surveillances, and program audits. Surveillance, nonconformance, audit, and corrective 
action documentation shall be routed to the project quality records on completion or closure of the activity. A report summarizing audit, surveillance, nonconformance, and corrective action, as well as any associated corrective actions, shall be prepared for the technical lead by QA at least semiannually. Such information will become part of the remedial investigation report. The final report shall include an assessment of the overall adequacy of the total measurement system with regard to the DQO of the investigation.

\subsection{REFERENCES}

ASTM, 1991, 1991 Annual Book of ASTM Standards, American Society for Testing and Materials, Philadelphia, Pennsylvania.

Ecology, EPA and DOE-RL, 1990, Hanford Federal Facility Agreement and Consent Order, First amendment, two volumes, 89-10 Rev.1, Washington Department of Ecology, Olympia, Washington, U.S. Environmental Protection Agency, Region X, Seattle, Washington, and U.S. Department of Energy, Richland Field Office, Richland, Washington.

EPA, 1986, Test Methods for Evaluating Solid Waste (SW-846), Third Edition, U.S. Environmental Protection Agency, Office of Solid Waste and Emergency Response, Washington, D.C.

EPA, 1991a, USEPA Contract Laboratory Program Statement of Work for Inorganics Analysis: Multi-Media Multi-Concentration, U.S. Environmental Protection Agency, Sample Management Laboratory, Washington, D.C.

EPA, 1991b, USEPA Contractor Laboratory Program Statement of Work for Organics Analysis: Multi-Media, Multi-Concentration, U.S. Environmental Protection Agency, Sample Management Laboratory, Washington, D.C.

Kopp, J. F., and G. D. McKee, 1983, Methods for Chemical Analysis of Water and Wastes, EPA-600/4-79-020, U.S. Environmental Protection Agency, Environmental Monitoring and Support Laboratory, Washington, D.C.

Krieger, H. L., and E. L. Whittaker, 1980, Prescribed Procedures for Measurement of Radioactivity in Drinking Water, EPA/600/4-80/032, U.S. Environmental Protection Agency, Environmental Monitoring and Support Laboratory, Cincinnati, Ohio.

Lindahl, P. C., 1984, Determination of Inorganic Anions in Aqueous and Solid Samples of Ion Chromatography, EPA/600/4-84/017, Argonne National Laboratory, Argonne, Illinois. 
Volchok, H. L., and G. dePlanque (editors), 1982, EML Procedures Monual, 25th edition, HASL-300-Ed.25, U.S. Department of Energy, Environmental Measurements Laboratory, New York, New York.

WHC, 1988a, Quality Assurance Manual, WHC-CM-4-2, et seq., Westinghouse Hanford Company, Richland, Washington.

WHC, 1988b, Environmental Investigations and Site Characterization Manual, WHC-CM-7-7, et seq., Westinghouse Hanford Company, Richland, Washington.

WHC, 1990a, Environmental Engineering, Technology, and Permitting Function Quality Assurance Program Plan, WHC-EP-0383, Westinghouse Hanford Company, Richland, Washington.

WHC, 1990b, Sample Management and Administration Manual, WHC-CM-5-3, Westinghouse Hanford Company, Richland, Washington.

WHC, 1990c, HEIS User's Manual, WHC-EP-0372, Westinghouse Hanford Company, Richland, Washington.

WHC, 1990d, Document Control and Records Management Manual, WHC-CM-3-5, Westinghouse Hanford Company, Richland, Washington. 
DOE/RL-91-07, Rev. 0

Table QAPjP-1. Analytical Methods, Analytical Parameters, Detection Limits, and Precision and Accuracy Requirements for the 100-BC-2 Source Operable Unit.

(Sheet 1 of 9)

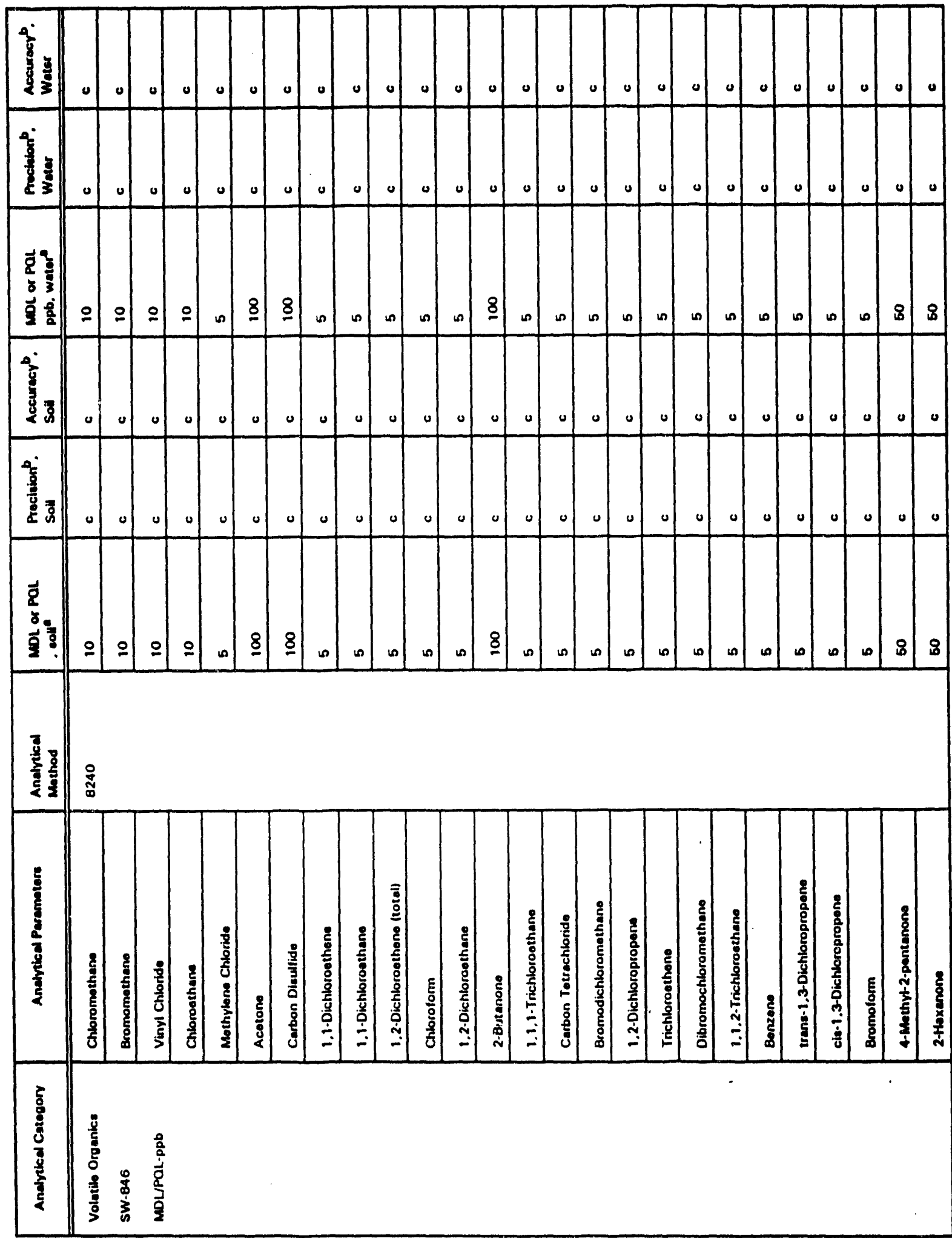


Table QAPjP-1. Analytical Methods, Analytical Parameters, Detection Limits, and Precision and Accuracy Requirements for the 100-BC-2 Source Operable Unit.

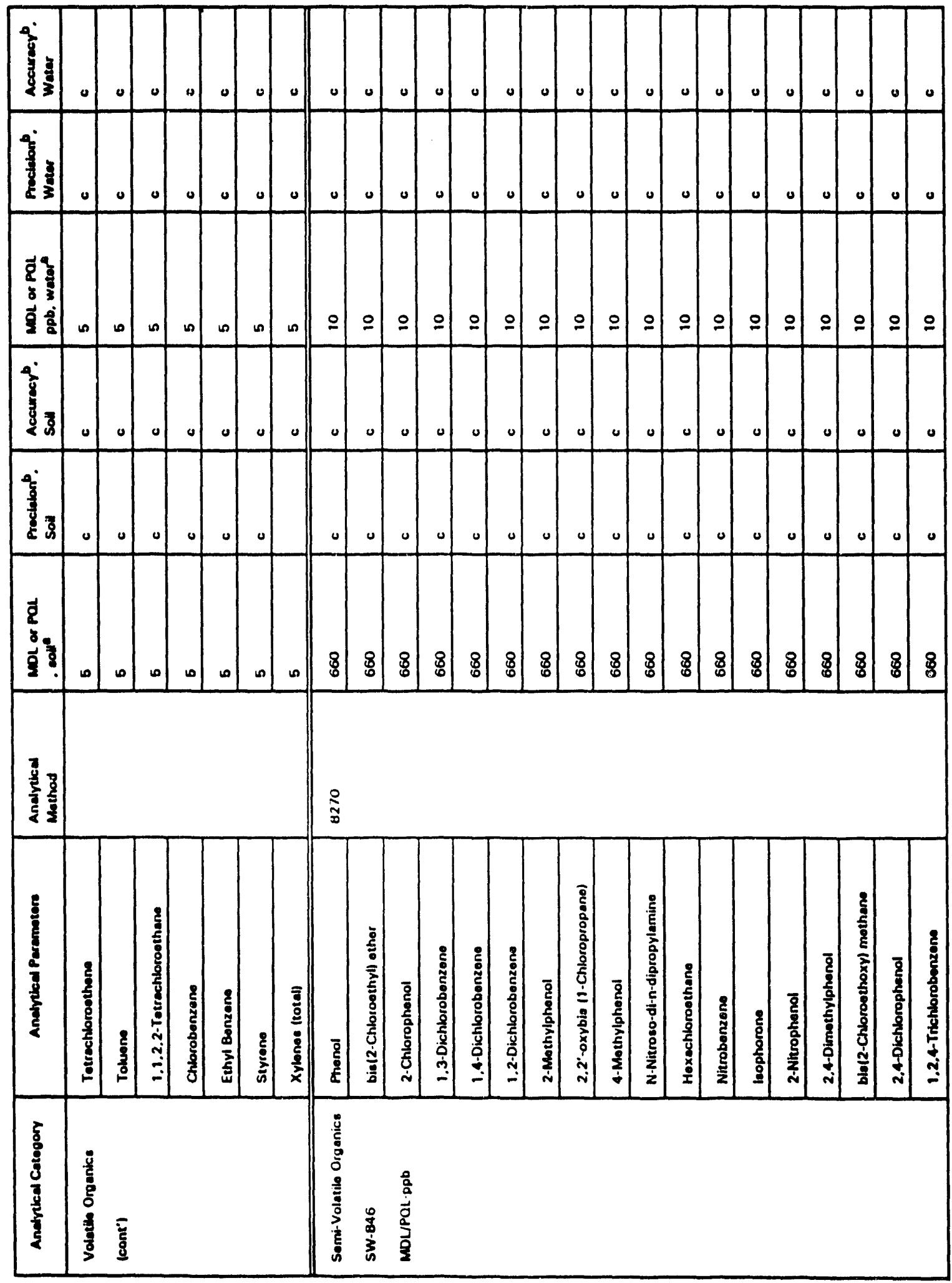


DOE/RL-91-07, Rev. 0

Table QAPjP-1. Analytical Methods, Analytical Parameters, Detection Limits, and Precision and Accuracy Requirements for the 100-BC-2 Source Operable Unit.

(Sheet 3 of 9)

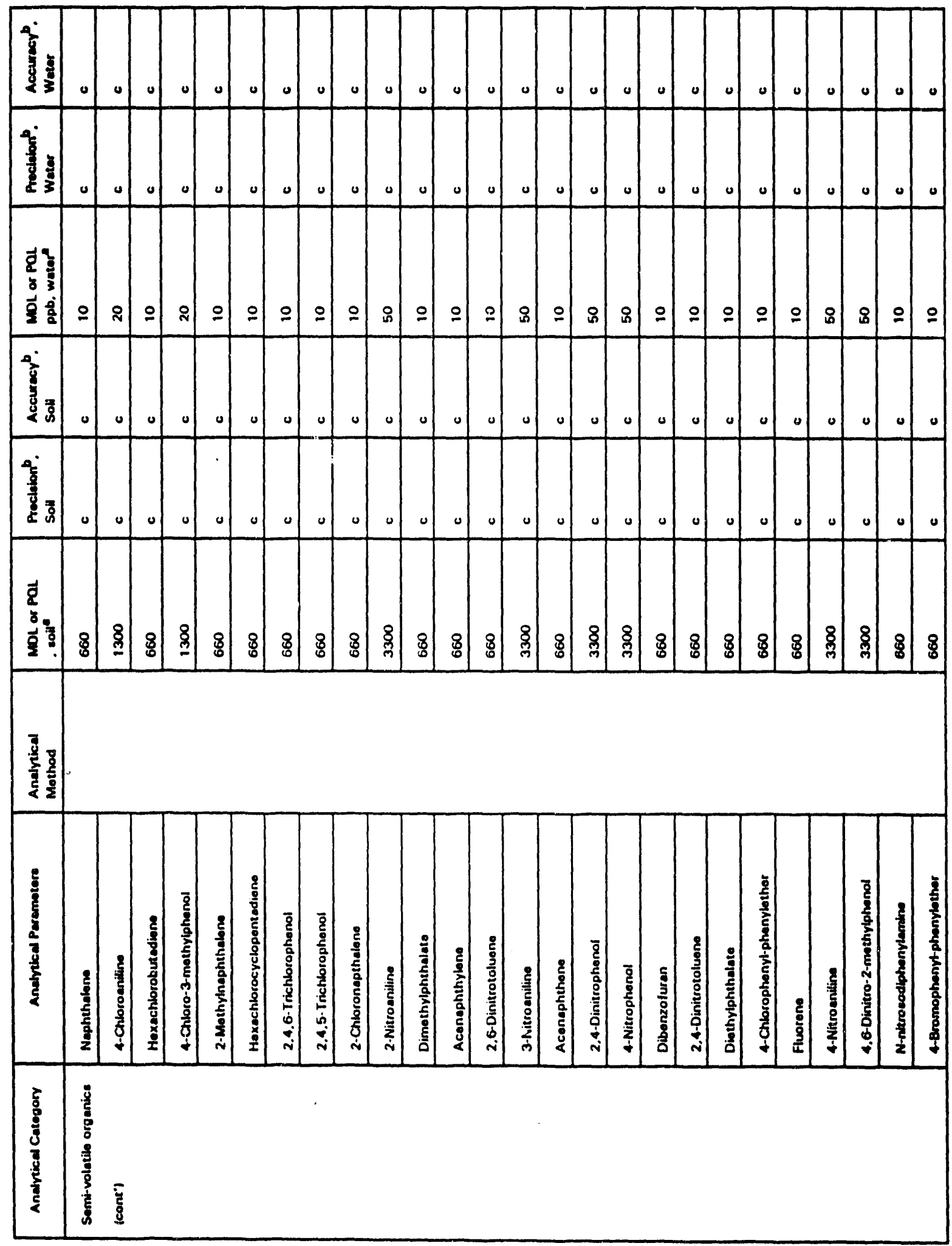


Table QAPJP-1. Analytical Methods, Analytical Parameters, Detection Limits, and i recision and Accuracy Requirements for the 100-BC-2 Source Operable Unit.

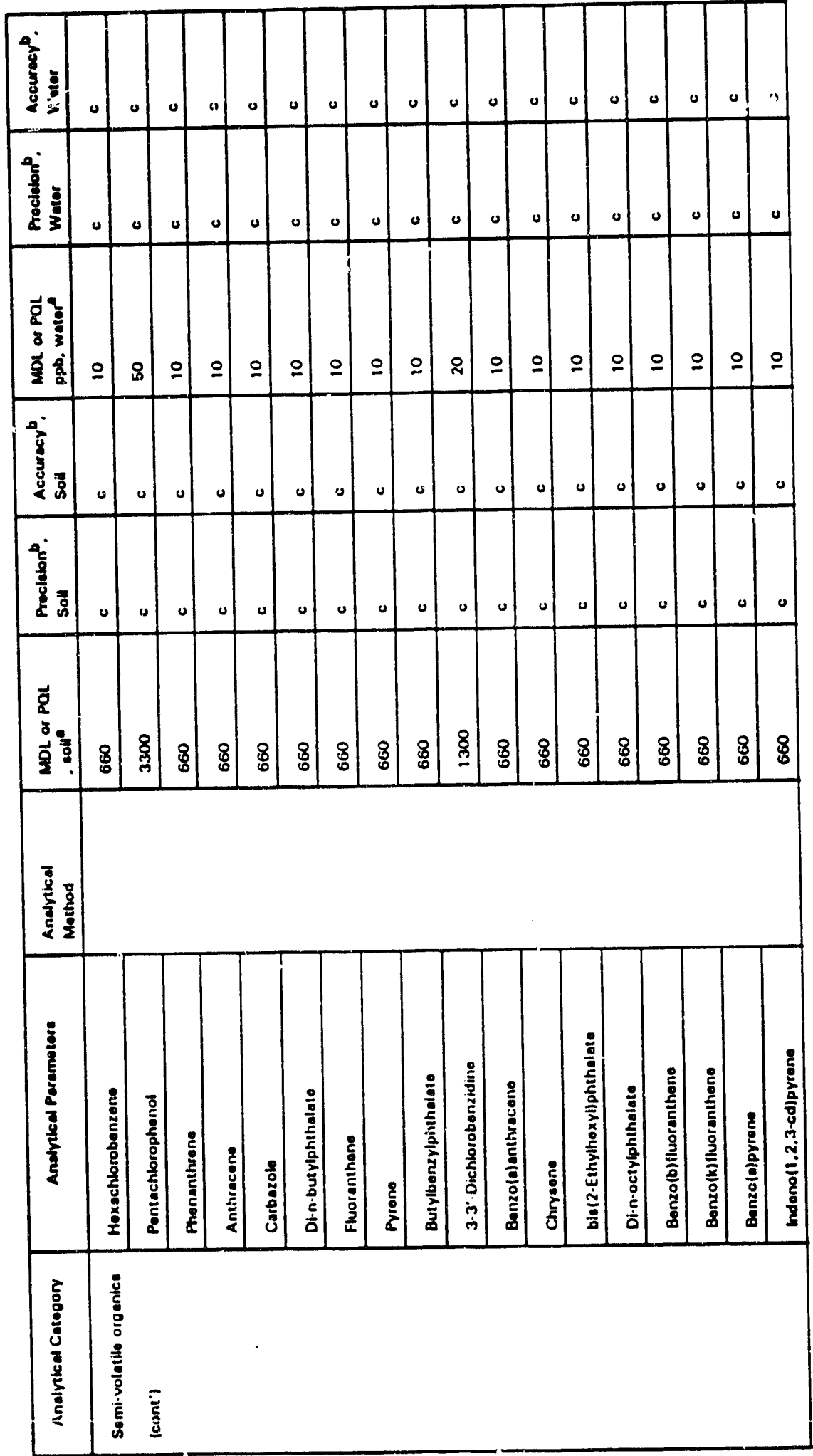


Table QAPjP-1. Analytical Methods, Analytical Parameters, Detection Limits, and Precision and Accuracy Requirements for the 100-BC-2 Source Operable Unit.

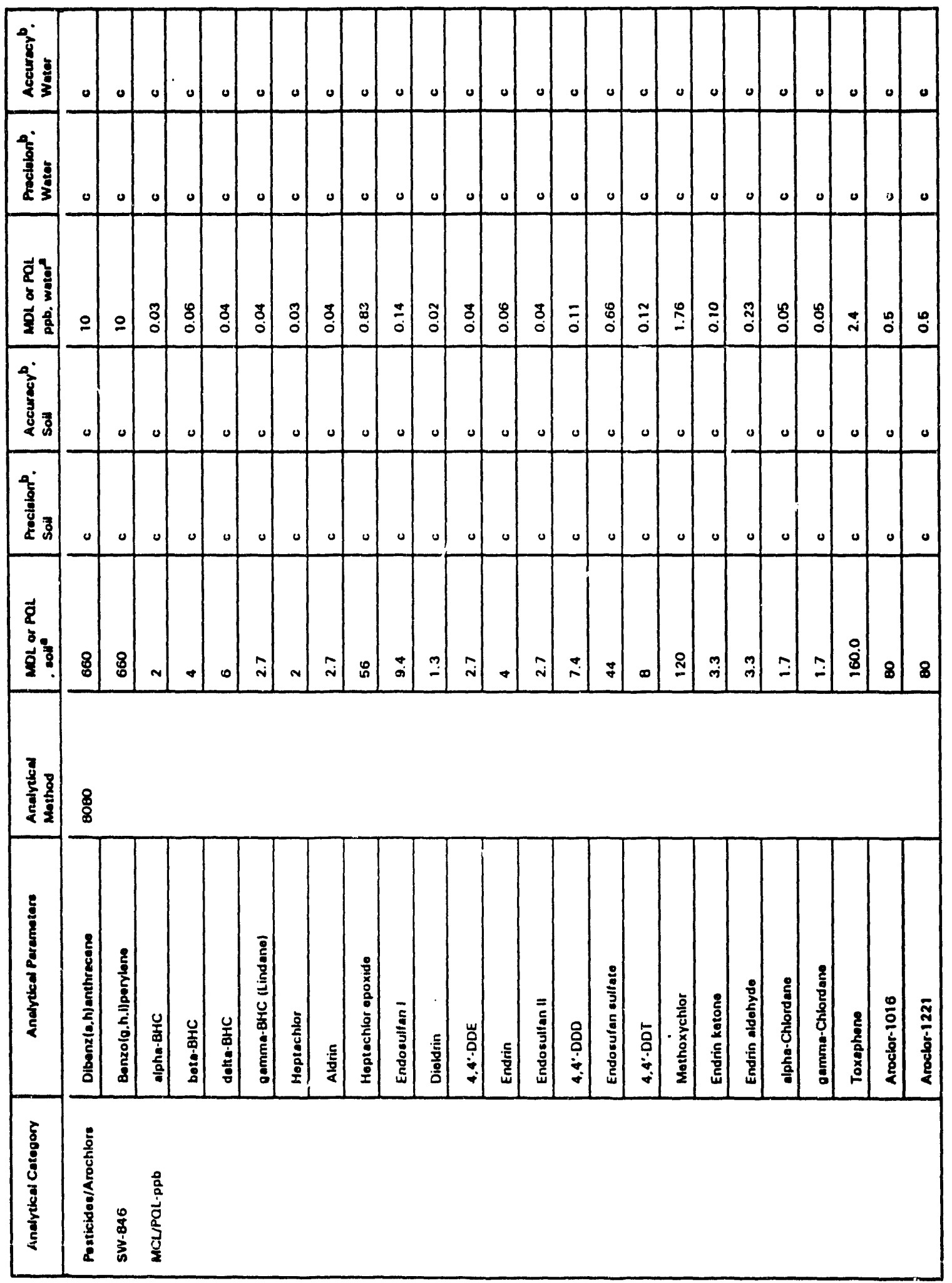


Table QAPjP-1. Analytical Methods, Analytical Parameters, Detection Limits, and Precision and Accuracy Requirements for the 100-BC-2 Source Operable Unit.

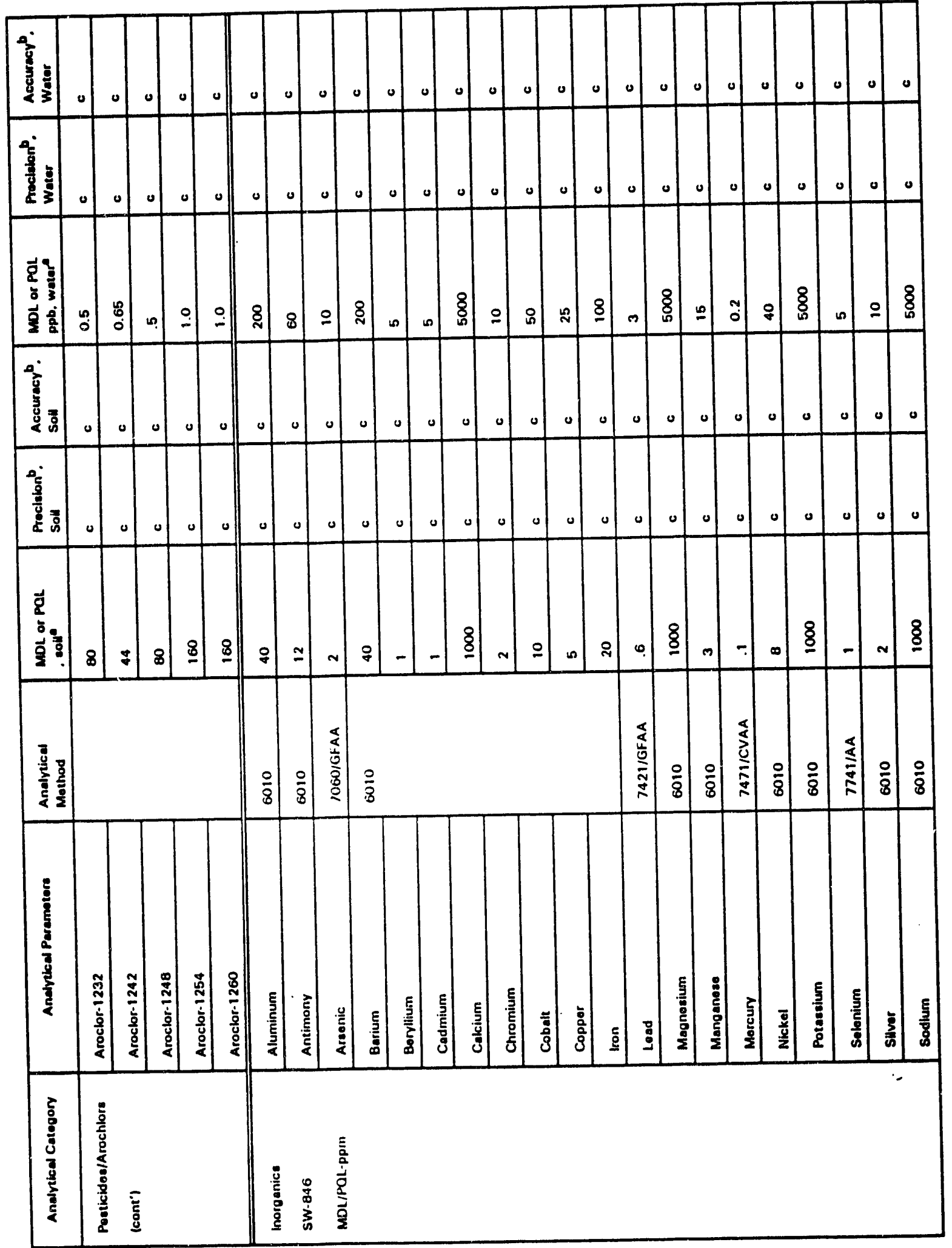


Table QAPjP-1. Analytical Methods, Analytical Parameters, Detection Limits, and Precision and Accuracy Requirements for the 100-BC-2 Source Operable Unit.

(Sheet 7 of 9)

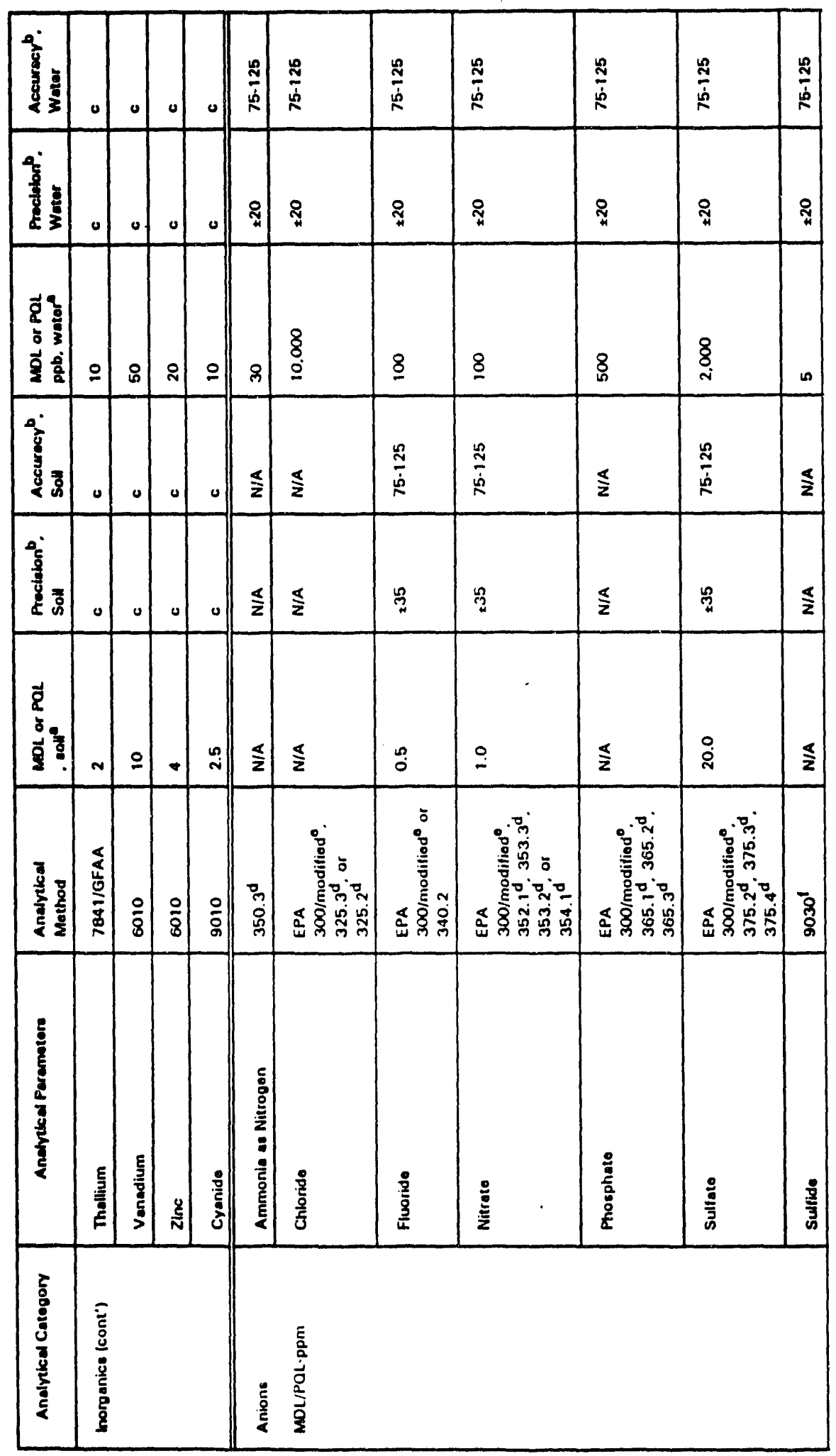


DOE/RL-91-07, Rev. 0

Table QAPjP-1. Analytical Methods, Analytical Parameters, Detection Limits, and Precision and Accuracy Requirements for the 100-BC-2 Source Operable Unit.

(Sheet 8 of 9)

\begin{tabular}{|c|c|c|c|c|c|c|c|c|c|c|c|c|c|c|}
\hline 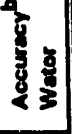 & $\frac{2}{5}$ & $-\frac{\stackrel{m}{\dot{s}}}{\hat{g}}$ & 总 & $\frac{\mathscr{D}}{\dot{\dot{S}}}$ & 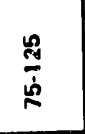 & 草 & $\frac{\mathscr{2}}{\tilde{B}}$ & 旁 & \begin{tabular}{l|l|}
$\underline{z}$ & $\underline{z}$
\end{tabular} & $\begin{array}{l}\frac{1}{2} \\
\mathbf{z}\end{array}$ & \begin{tabular}{l|l|}
$\mathbf{s}$ & $\mathbf{s}$ \\
\end{tabular} & $\frac{\mathbf{s}}{\mathbf{z}}$ & 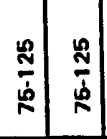 & $\frac{\mathbf{s}}{\mathbf{z}}$ \\
\hline 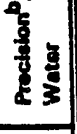 & $\$$ & $-\approx$ & 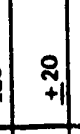 & ๙ & $\stackrel{\Re}{2}$ & 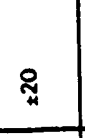 & ฆి & § & : & \begin{tabular}{|l|}
5 \\
\end{tabular} & $\div$ & ฐి ะ & & 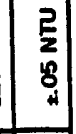 \\
\hline 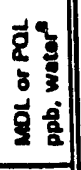 & $\begin{array}{l}5 \\
\vdots \\
\vdots \\
8 \\
+\end{array}$ & & $\mid$ & $\begin{array}{l}\frac{a}{3} \\
\text { n. }\end{array}$ & 竭 & 彦 & $\begin{array}{l}\frac{1}{3} \\
\vdots \\
0 \\
0\end{array}$ & $\stackrel{8}{8}$ & \begin{tabular}{l|l}
8 & \\
- & 2 \\
\end{tabular} & $\begin{array}{lll} & \frac{s}{2}\end{array}$ & \begin{tabular}{l|l}
$\mathbf{5}$ & 8 \\
\end{tabular} & \begin{tabular}{|c|c}
8 & 8 \\
& 8 \\
\end{tabular} & & \begin{tabular}{|l|} 
\\
2 \\
0 \\
0 \\
0 \\
\end{tabular} \\
\hline 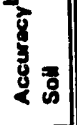 & $\frac{\mathbf{s}}{\mathbf{z}}$ & 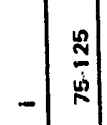 & $\frac{\mathbf{s}}{\mathbf{2}}$ & $\frac{\mathscr{R}}{\stackrel{2}{*}}$ & 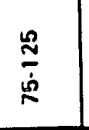 & 葛 & 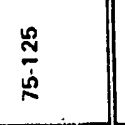 & $\frac{a}{z}$ & \begin{tabular}{l|l|}
$\frac{s}{2}$ & $\frac{s}{2}$ \\
\end{tabular} & \begin{tabular}{|l|l}
$\frac{1}{z}$ & $\frac{\Xi}{2}$ \\
\end{tabular} & 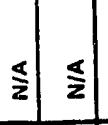 & $\frac{5}{2} \frac{5}{2}$ & \begin{tabular}{l|l}
$\frac{\$}{2}$ & $\frac{\$}{z}$
\end{tabular} & $\frac{\$}{z}$ \\
\hline 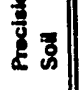 & \begin{tabular}{|l|} 
\\
\end{tabular} & - & $\frac{1}{2}$ & 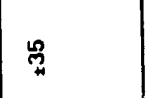 & $\stackrel{2}{2}$ & 号 & $\stackrel{\mathscr{g}}{2}$ & $\frac{\Delta}{z}$ & \begin{tabular}{l|l|l}
$\frac{s}{z}$ & $\frac{s}{z}$
\end{tabular} & \begin{tabular}{|l|l}
$\frac{5}{z}$ & $\frac{5}{2}$
\end{tabular} & \begin{tabular}{l|l|l|}
$\frac{s}{2}$ & $\frac{5}{2}$
\end{tabular} & \begin{tabular}{|l|l}
$\mid \frac{s}{z}$ & $\frac{5}{z}$
\end{tabular} & $\frac{1}{z}\left|\frac{s}{z}\right|$ & $\frac{\mathbf{s}}{\mathbf{z}}$ \\
\hline | & $\frac{\$}{\mathbf{z}}$ & 空 & $\frac{1}{2}$ & 总 & 莣 & $\stackrel{\circ}{\bar{i}}$ & $\begin{array}{l}0 \\
\bar{z} \\
\vdots \\
0 \\
0 \\
\end{array}$ & $\frac{\pi}{2}$ & \begin{tabular}{l|l}
$\frac{1}{2}$ & $\frac{1}{2}$ \\
\end{tabular} & \begin{tabular}{l|l|l}
$\frac{s}{z}$ & $\frac{s}{2}$
\end{tabular} & 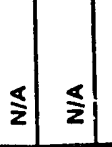 & \begin{tabular}{l|l|l}
$\mathbf{z}$ & $\underline{\mathbf{z}}$ \\
\end{tabular} & \begin{tabular}{l|l}
$\mathbf{z}$ & $\mathbf{s}$ \\
\end{tabular} & $\frac{s}{2}$ \\
\hline 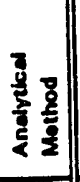 & $\begin{array}{c}0 \\
\vdots \\
\vdots \\
\vdots \\
\vdots \\
\vdots \\
\vdots\end{array}$ & 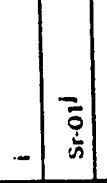 & $=$ & 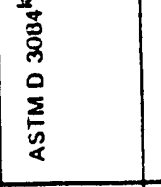 & 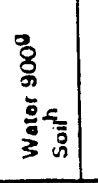 & 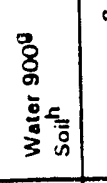 & 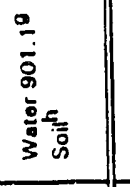 & \begin{tabular}{l|l} 
\\
0 \\
\end{tabular} & - & $-1-$ & 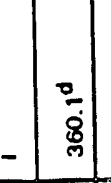 & & 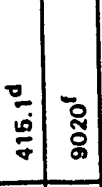 & $\frac{\square}{\square-\sigma}$ \\
\hline 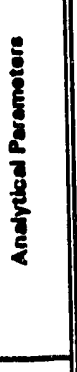 & 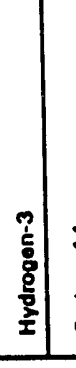 & 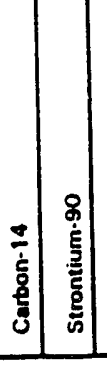 & & 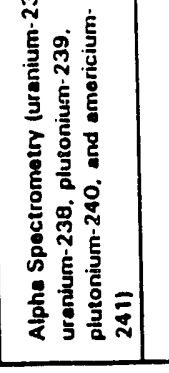 & 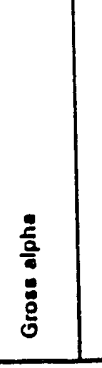 & $\begin{array}{l}0 \\
\vdots \\
\vdots \\
0 \\
0 \\
0\end{array}$ & 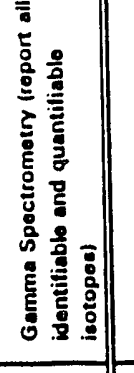 & \begin{tabular}{l|l} 
& \multicolumn{2}{c}{} \\
& \\
$\vdots$
\end{tabular} & 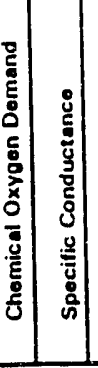 & \begin{tabular}{|c|c} 
\\
I
\end{tabular} & 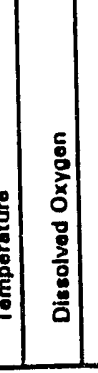 & 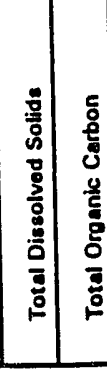 & 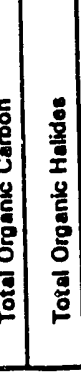 & 童 \\
\hline 递 & 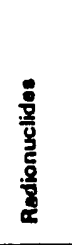 & & & & & & & 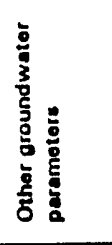 & & & & & & \\
\hline
\end{tabular}


Table QAPjP-1. Analytical Methods, Analytical Parameters, Detection Limits, and Precision and Accuracy Requirements for the 100-BC-2 Source Operable Unit.

(Sheet 9 of 9)

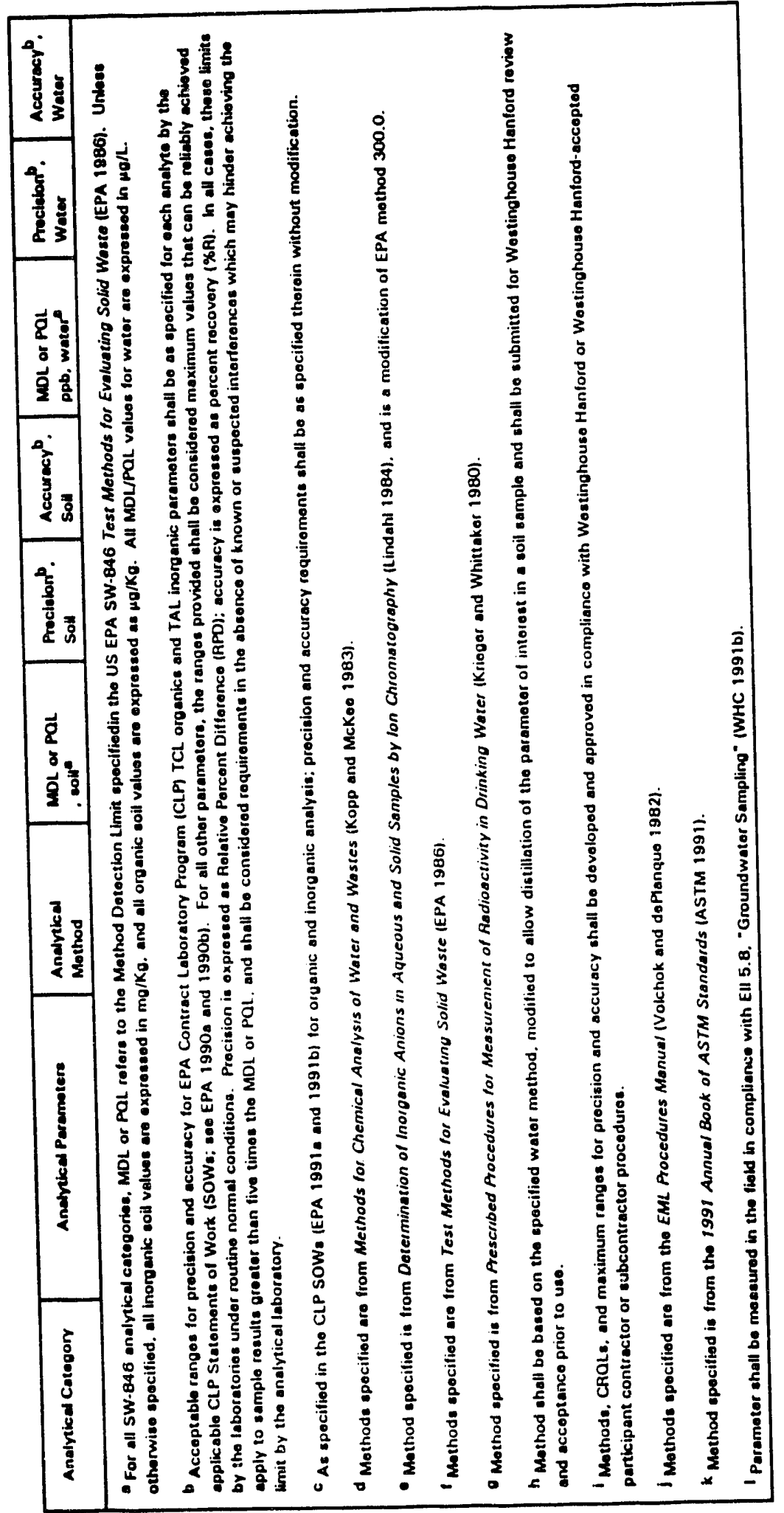


Table QAPjP-2. Sampling and Investigative Procedures for the Limited Field Investigations in the 100-BC-2 Source Operable Unit.

\begin{tabular}{|c|c|c|c|c|c|c|c|c|c|c|c|}
\hline 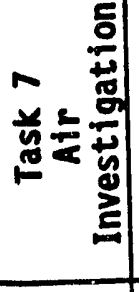 & $x$ & $x$ & $x$ & & $\times 1=$ & $x$ & $x$ & & $x$ & $\times$ & $x$ \\
\hline 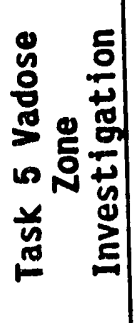 & $x$ & $x$ & $x$ & $\times$ & $\times$ & $x$ & $x$ & & $x$ & $x$ & $x$ \\
\hline m & & & & & & & & & & & \\
\hline 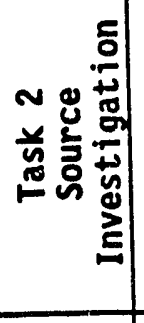 & $\times$ & $x$ & $x$ & $x>$ & $\times$ & $x$ & $x$ & $x$ & $x$ & $\times$ & $x$ \\
\hline 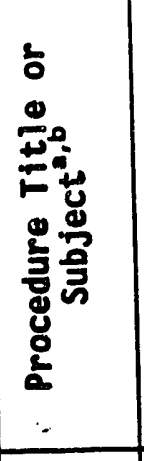 & 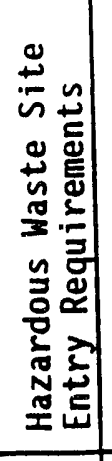 & 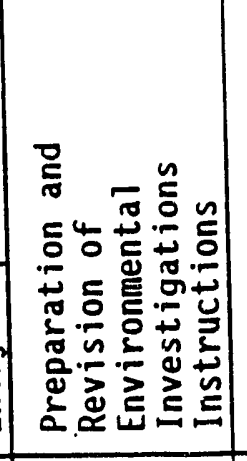 & 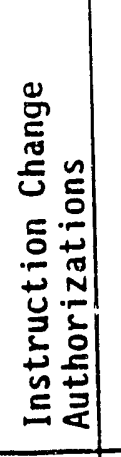 & 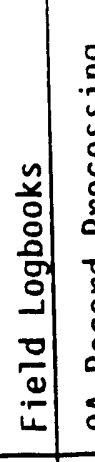 & 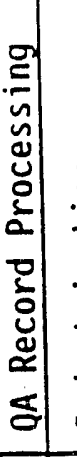 & 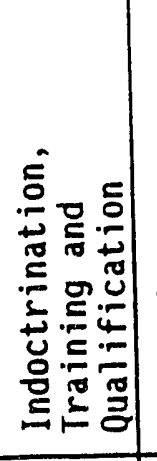 & 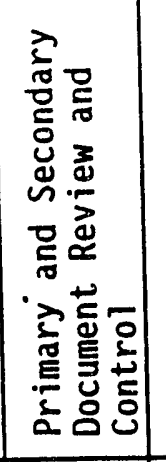 & 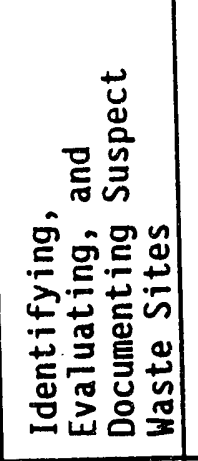 & 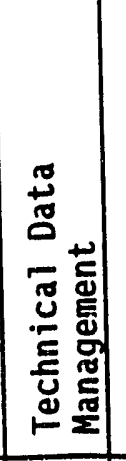 & 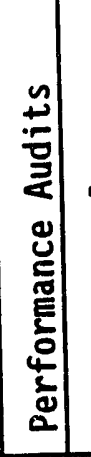 & 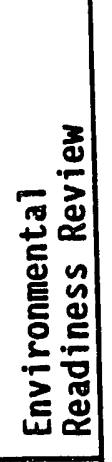 \\
\hline & $\begin{array}{l}\vec{\Xi} \\
\Xi\end{array}$ & 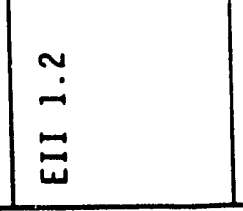 & $\begin{array}{l}\stackrel{+}{ \pm} \\
\Xi\end{array}$ & $\begin{array}{l}? \\
\overrightarrow{3} \\
\overrightarrow{5}\end{array}$ & $\begin{array}{l}0 \\
- \\
- \\
\vec{\omega}\end{array}$ & $\begin{array}{l}\Xi \\
\Xi\end{array}$ & $\begin{array}{l}\stackrel{9}{\vec{z}} \\
\vec{\Xi}\end{array}$ & $\begin{array}{l}\stackrel{0}{二} \\
\Xi\end{array}$ & $\begin{array}{l}\Xi \\
\Xi \\
ت\end{array}$ & $\begin{array}{l}\simeq \\
- \\
\Xi\end{array}$ & 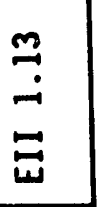 \\
\hline
\end{tabular}


DOE/RL-91-07, Rev. 0

Table QAPJP-2. Sampling and Investigative Procedures for the Limited Field Investigations in the 100-BC-2 Source

Operable Unit.

(Sheet 2 of 4)

\begin{tabular}{|c|c|c|c|c|c|c|c|c|c|}
\hline 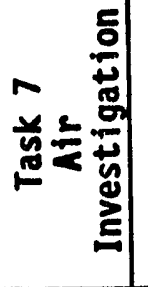 & & $x$ & $x$ & & $x$ & & & & \\
\hline 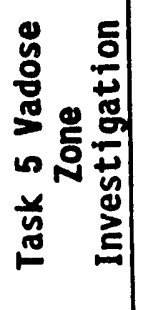 & $\times$ & $x$ & $x$ & $x$ & $x$ & $x$ & $x$ & $x$ & $x$ \\
\hline 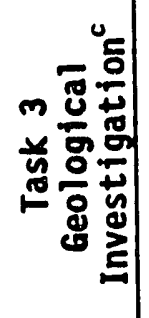 & & & & & & & & & \\
\hline 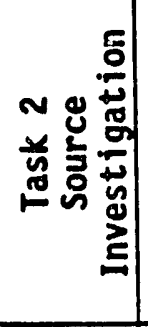 & $x$ & $x$ & $x$ & $x$ & $x$ & $x$ & $x$ & $x$ & \\
\hline 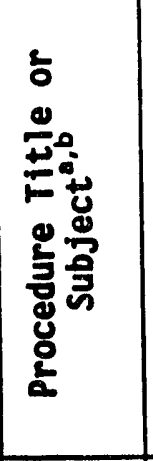 & 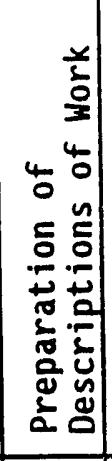 & 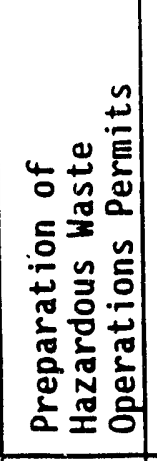 & 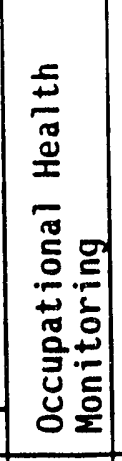 & 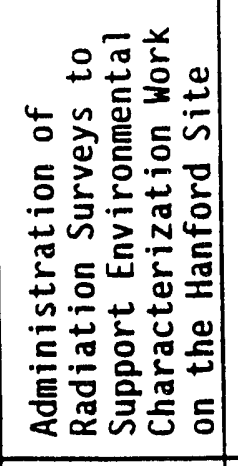 & 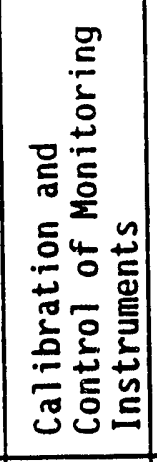 & 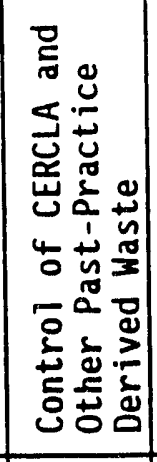 & $\begin{array}{l}3 \\
0 \\
0 \\
0 \\
4 \\
0 \\
.5 \\
0 \\
0 \\
\end{array}$ & 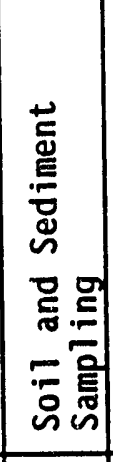 & 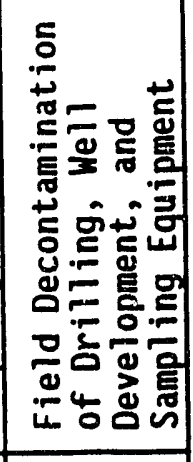 \\
\hline & $\begin{array}{l} \pm \\
\vdots \\
\Xi\end{array}$ & $\begin{array}{l}\vec{a} \\
\vec{z}\end{array}$ & $\begin{array}{l}\tilde{N} \\
\tilde{a} \\
\vec{z}\end{array}$ & $\begin{array}{l}m \\
i \\
\vec{z}\end{array}$ & $\begin{array}{r}\tilde{m} \\
\ddot{z}\end{array}$ & $\begin{array}{l}m \\
\dot{m} \\
\Xi\end{array}$ & : & 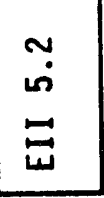 & $\begin{array}{l}\dot{+} \\
\dot{\omega} \\
\Xi \\
\end{array}$ \\
\hline
\end{tabular}


Table QAPjP-2. Sampling and Investigative Procedures for the Limited Field Investigations in the $100-\mathrm{BC}-2$ Source Operable Unit.

\begin{tabular}{|c|c|c|c|c|c|c|c|c|c|}
\hline r & & & & & $x$ & & & & \\
\hline 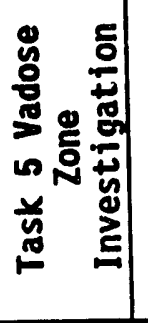 & $x$ & $x$ & $x$ & $x$ & & $x$ & $x$ & $x$ & $\times$ \\
\hline 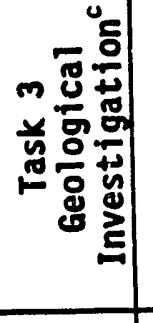 & & & & & & & & & \\
\hline 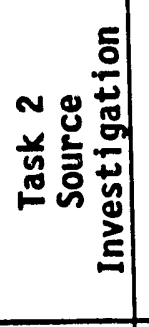 & $x$ & $x$ & $x$ & $\times$ & & $\times$ & & & \\
\hline 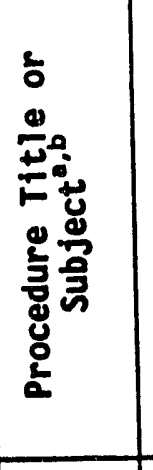 & 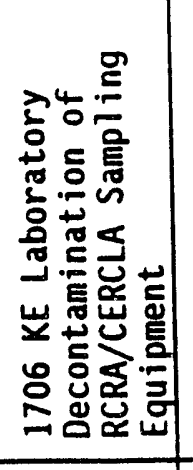 & 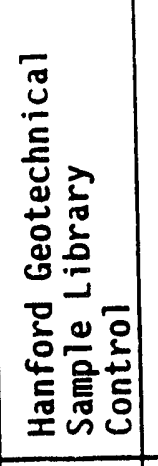 & 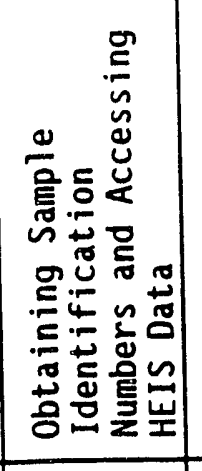 & 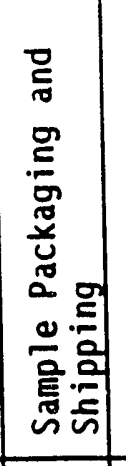 & 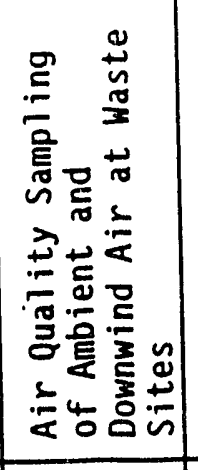 & 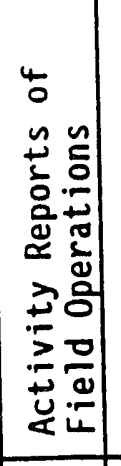 & 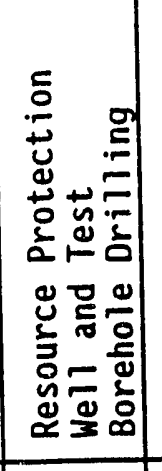 & 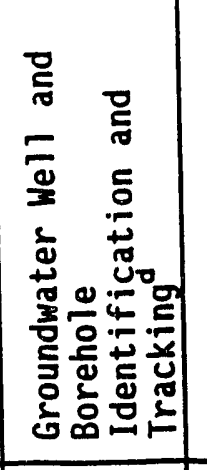 & \begin{tabular}{|c|}
0 \\
0 \\
0 \\
0 \\
0 \\
0 \\
0 \\
8 \\
0
\end{tabular} \\
\hline & $\tilde{\omega}$ & $\begin{array}{l}\stackrel{5}{n} \\
\text { in } \\
\Xi \\
\Xi\end{array}$ & $\begin{array}{l}\stackrel{0}{\text { in }} \\
\stackrel{\vec{\omega}}{\Xi}\end{array}$ & $\begin{array}{l}\vec{Z} \\
\vec{w} \\
\vec{w}\end{array}$ & $\begin{array}{l}\cong \\
\dot{3} \\
\Xi\end{array}$ & $\begin{array}{l}\overrightarrow{0} \\
\vec{E}\end{array}$ & $\begin{array}{l}\overrightarrow{0} \\
\vec{z}\end{array}$ & $\begin{array}{l}\stackrel{9}{0} \\
0 \\
\Xi \\
\Xi\end{array}$ & $\vec{a}$ \\
\hline
\end{tabular}


Table QAPjP-2. Sampling and Investigative Procedures for the Limited Field Investigations in the 100-BC-2 Source Operable Unit.

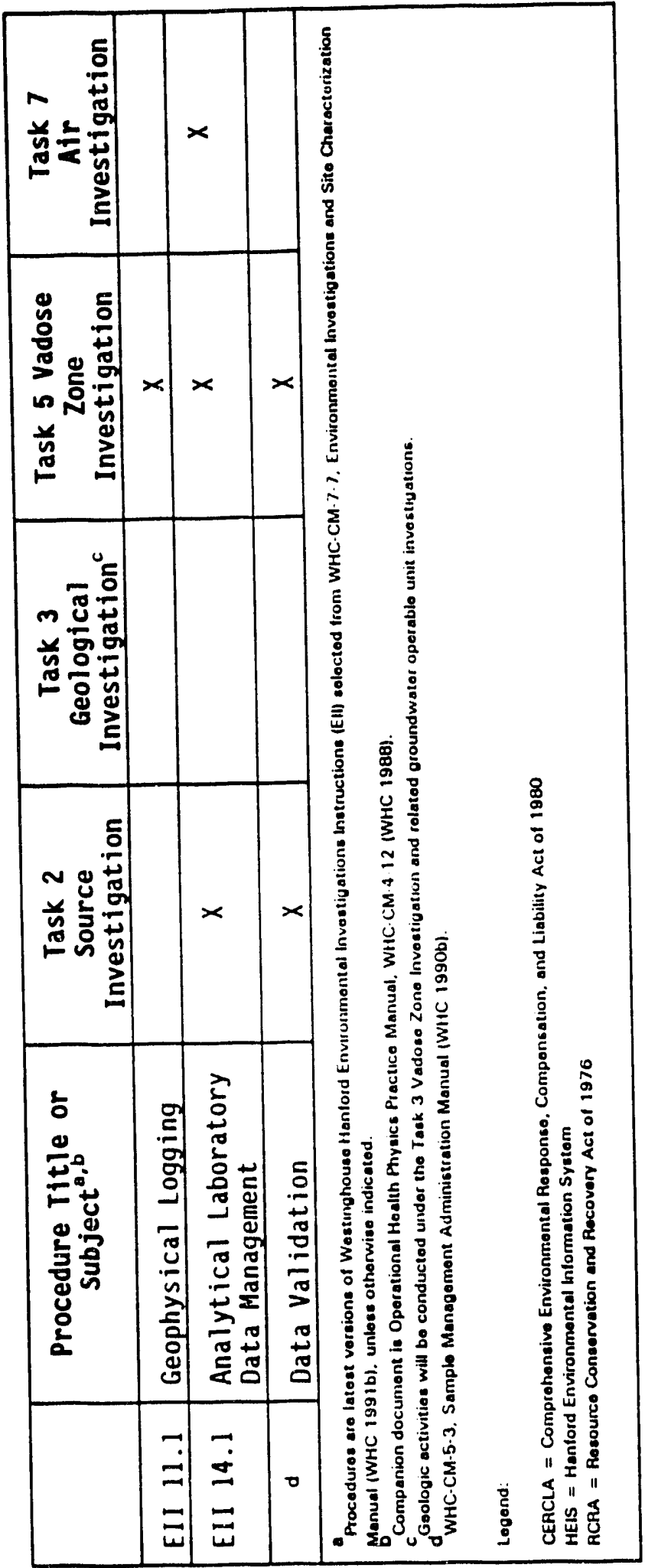


DOE/RL-91-07, Rev. 0

APPENDIX B

HEALTH AND SAFETY PLAN 


\section{CONTENTS}

1.0 GENERAL CONSIDERATIONS AND REQUIREMENTS $\ldots \ldots \ldots \ldots \ldots$ B-1

$\ldots \ldots \ldots \ldots \ldots \ldots, B \ldots \ldots, B \ldots \ldots$

1.2 DESIGNATED SAFETY PERSONNEL $\ldots \ldots \ldots \ldots \ldots \ldots \ldots$ B-1

MEDICAL SURVEILLANCE $\ldots \ldots \ldots \ldots \ldots \ldots \ldots$ B-3

14 TRAINING $\ldots \ldots \ldots \ldots \ldots \ldots$ B-3

1.4 TRAINING FOR VISITORS $\ldots \ldots \ldots \ldots \ldots \ldots \ldots \ldots$ B-3

1.5 TRAINING FOR VISTETRY $\ldots \ldots \ldots \ldots \ldots \ldots \ldots \ldots$ B-4

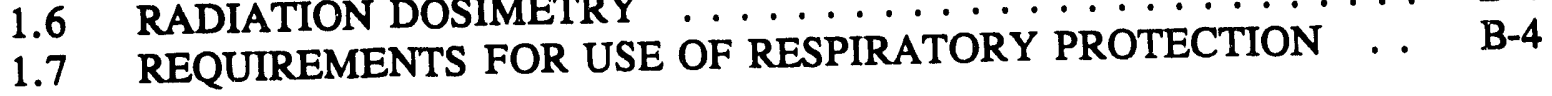

2.0 GENERAL PROCEDURES $\ldots \ldots \ldots \ldots \ldots \ldots$

2.1 GENERAL WORK SAFETY PRACTICES $\ldots \ldots \ldots \ldots \ldots \ldots$ B-4

2.1 .1 Work Practices $\ldots \ldots \ldots \ldots \ldots \ldots \ldots \ldots \ldots \ldots \ldots$

2.1.2 Personal Protective Equipment $\ldots \ldots \ldots \ldots \ldots \ldots \ldots \ldots$ B-6

2.1.3 Personal Decontamination $\ldots \ldots \ldots \ldots \ldots \ldots \ldots \ldots \ldots$ B-7

2.1 .4 Emergency Preparation . . . . . . . . . . . . . .

2.2 CONFINED SPACE/TEST PIT ENTRY PROCEDURES $\ldots \ldots \ldots$ B-8

4.0 SCOPE OF WORK AND POTENTIAL HAZARDS $\ldots \ldots \ldots$

WORK TASKS $\ldots \ldots \ldots \ldots \ldots$ B-10

4.2 POTENTIAL HAZARDS .................. B-10

4.3 ASSESSMENT AND MITIGATION OF POTENTIAL HAZARDS .. B-11

5.0 ENVIRONMENTAL AND PERSONAL MONITORING $\ldots \ldots \ldots \ldots$ B-11

6.0 PERSONAL PROTECTIVE EQUIPMENT $\ldots \ldots \ldots \ldots \ldots \ldots \ldots$. . . . . $\ldots$

8.0 DECONTAMINATION PROCEDURES $\ldots \ldots \ldots \ldots \ldots \ldots \ldots$. . . . . .

9.0 CONTINGENCY AND EMERGENCY RESPONSE PLANS $\ldots \ldots \ldots \ldots$ B-14

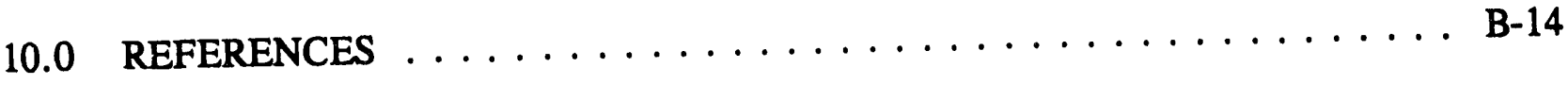




\subsection{GENERAL CONSIDERATIONS AND REQUIREMENTS}

\subsection{INTRODUCTION}

The purpose of this health and safety plan (HSP) is to establish standard health and safety procedures for Westinghouse Hanford Company (WHC) employees and contractors engaged in remedial investigation (RI) activities in the 100-BC-2 operable unit. These activities will include surface investigation, drilling and sampling boreholes, and environmental sampling in areas of known chemical and radiological contamination. Appropriate site-specific safety documents [e.g., hazardous waste operations permit (HWOP) or job safety analysis (JSA)] will be written for each task or group of tasks.

All employees of WHC or any other contractors who are participating in onsite activities in the 100-BC-2 operable unit shall read the site-specific safety document and attend a pre-job safety or tailgate meeting to review and discuss the task.

\subsection{DESIGNATED SAFETY PERSONNEL}

The field team leader and site safety officer are responsible for site safety and health. Specific individuals will be assigned on a task-by-task basis by project management, and their names will be properly recorded before the task is initiated.

All activities onsite must be cleared through the field team leader. The field team leader has responsibility for the following.

- Allocating and administering resources to successfully comply with all technical and health and safety requirements.

- Verifying that all permits, supporting documentation, and clearances are in place (e.g., electrical outage requests, welding permits, excavation permits, HWOP or JSA, sampling plan, radiation work permits [RWP], and onsite/ offsite radiation shipping records).

- $\quad$ Providing technical advice during routine operations and emergencies.

- Informing the appropriate site management and safety personnel of the activities to be performed each day.

- Coordinating resolution of any conflicts that may arise between RWP and the implementation of the HWOP or JSA with health physics.

- Handling emergency response situations as required.

- $\quad$ Conducting pre-job and daily tailgate safety meetings.

- Interacting with adjacent building occupants/inquisitive public. 
The site safety officer is responsible for implementing the HWOP at the site. The site safety officer shall do the following.

- Monitor chemical, physical, and (in conjunction with the health physics technician) radiation hazards to assess the degree of hazard present; monitoring shall specifically include organic vapor detection, radiation screening, and confined space evaluation where appropriate.

- Determine protection levels, clothing, and equipment needed to ensure the safety of personnel in conjunction with WHC Health Physics.

- Monitor the performance of all personnel to ensure that the required safety procedures are followed.

- Halt operations immediately, if necessary, because of safety or health concerns.

- Conduct safety briefings as necessary.

- Assist the field team leader in conducting safety briefings as necessary.

The health physics technician is responsible for ensuri..g that all radiological monitoring and protection procedures are being followed as specified in the Radiation Protection Manual (WHC 1988a) and in the appropriate RWP. WHC Industrial Safety and Fire Protection personnel will provide safety overview during drilling operations consistent with WHC policy and, as requested, will provide technical advice. Also, downwind sampling for hazardous materials and radiological contaminants and other analyses may be requested from appropriate contractor personnel as required.

The ultimate responsibility and authority for employee's health and safety lies with the employee and the employee's colleagues. Each employee is responsible for exercising the utmost care and good judgment in protecting his or her personal health and safety and that of fellow employees. Should any employee observe a potentially unsafe condition or situation, it is the responsibility of that employee to immediately bring the observed condition to the attention of the appropriate health and safety personnel, as designated previously. In the event of an immediately dangerous or life-threatening situation, the employee automatically has temporary "stop work" authority and the responsibility to immediately notify the field team leader or site safety officer. When work is temporarily halted because of a safety or health concern, personnel will exit the exclusion zone and meet at a predetermined place in the support zone. The field team leader, site safety officer, and health physics technician will determine the next course of action. 


\subsection{MEDICAL SURVEHLANCE}

All field team members engaged in operable unit activities at sites governed by an HWOP must have baseline physical examinations and be participants in WHC (or an equivalent; hazardous waste worker medical surveillance program.

Medical examinations will be designed to identify any pre-existing conditions that may place an employee at high risk, and will verify that each worker is physically able to perform the work required by this work plan without undue risk to personal health. The physician shall determine the existence of conditions that may reduce the effectiveness or prevent the employee's use of respiratory protection. The physician shall also determine the presence of conditions that may pose undue risk to the employee while performing the physical tasks of this work plan using level B personal protection equipment. This would include any condition that increases the employee's susceptibility to heat stress.

The examining physician's report will not include any nonoccupational diagnoses unless directly app'icable to the employee's fitness for the work required.

\subsection{TRAINING}

Before engaging in any onsite RI activities, each team member is required to have received $40 \mathrm{hr}$ of health and safety training related to hazardous waste site operations and at least $8 \mathrm{hr}$ of refresher training each year thereafter as spec fied in 29 CFR 1910.120. In addition, each inexperience employee (never having performed site characterization) will be directly supervised by a trained/experienced person for a minimum of $24 \mathrm{hr}$ of field experience.

The field team leader and the site safety officer directly responsible for employees engaged in hazardous waste operations shall receive an additional $8 \mathrm{hr}$ of training (in addition to the refresher training previously discussed) as specified in WAC 296-62-3040(4).

\subsection{TRAINING FOR VISITORS}

For the purposes of this plan, a visitor is defined as any person visiting the Hanford Site, who is not a WHC employee or a WHC contractor directly involved in the Resource Conservation and Recovery Act of 1976/Comprehensive Environmental Response, Compensation, and Liability Act of 1980 (RCRA/CERCLA) facility investigation activities, including but not limited to those engaged in surveillance, inspection, or observation activities.

Visitors who must, for whatever reason, enter a controlled (either contamination reduction or exclusion) zone, shall be subject to all of the applicable training, respirator fit testing, and medical surveillance requirements discussed in WHC Environmental Investigations Iñstruction (EII) 1.1, Hazardous Waste Site Entry Requirements, and 
Appendix B to EII 1.1 (WHC 1988b). All visitors shall be informed of potential hazards and emergency procedures by their escorts and shall conform to EII 1.1 (WHC 1988b).

\subsection{RADIATION DOSIMETRY}

All personnel engaged in onsite activities shall be assigned dosimeters according to the requirements of the RWP applicable to that activity. All visitors shall be assigned basic dosimeters, as a minimum, that will be exchanged annually.

\subsection{REQUIREMENTS FOR USE OF RESPIRATORY PROTECTION}

All employees of WHC and subcontractors who may be required to use air-purifying or air-supplied respirators must be included in the medical surveillance program and be approved for the use of respiratory protection by the Hanford Environmental Health Foundation (HEHF) or other licensed physician. Each team member must be trained in the selection, limitations, and proper use and maintenance of respiratory protection (existing respiratory pre zction training may be applicable toward the 40-hr training requirement).

Before using a negative pressure respirator, each employee must have been fit-tested (within the previous year) for the specific make, model, and size according to WHC fittesting procedures. Beards (including a few days' growth), large sideburns, or moustaches that may interfere with a proper respirator seal are not permitted.

Subcontractors must provide evidence to WHC that personnel are participants in a medical surveillance and respiratory protection program that complies with 29 CFR 1910.120 and 29 CFR 1910.134, respectively.

\subsection{GENERAL PROCEDURES}

The following personal hygiene and work practice guidelines are intended to prevent injuries and adverse health effects. A hazardous waste site poses a multitude of health and safety concerns because of the variety and number of hazardous substances present. These guidelines represent the minimum standard procedures for reducing potential risks associated with this project and are to be followed by all job site employees at all times.

\subsection{GENERAL WORK SAFETY PRACTICES}

\subsubsection{Work Practices}

The following work practices must be observed.

- Eating, drinking, smoking, taking medications, chewing gum, and similar actions are prohibited within the exclusion zone. All sanitation facilities shall 
be located outside the exclusion zone; decontamination is required before using such facilities.

- Personnel shall avoid direct contact with contaminated materials unless necessary for sample collecting or required observation. Remote handling of such things as casings and auger flights will be practiced whenever practical.

- While operating in the controlled zone, personnel shall use the "buddy system" where appropriate, or be in visual contact with someone outside of the controlled zone.

- The buddy system will be used where appropriate for manual lifting.

- $\quad$ Requirements of WHC radiation protection and RWP manuals shall be followed for all work involving radioactive materials or conducted within a radiologically controlled area.

- Onsite work operations shall only be carried out during daylight hours, unless the entire control zone is adequately illuminated with artificial lighting. A new tour (shift) will operate the drilling rig after completion of each shift.

- Personnel will not handle soil, waste samples, or any other potentially contaminated items unless wearing the protective gloves specified in the HWOP or JSA.

- Whenever possible, personnel will stand upwind of excavations, boreholes, well casings, drilling spoils, and the like, as indicated by an onsite windsock.

- Personnel will stand clear of trenches during excavation; always approach an excavation from upwind.

- $\quad$ Personnel will be alert to potentially changing exposure conditions as evidenced by such indications as perceptible odors, unusual appearance of excavated soils, or oily sheen on water.

- Personnel will not enter any test pit or trench deeper than $4 \mathrm{ft}$ unless in accordance with procedures specified in the HWOP.

- Personnel will not under any circumstances enter or ride in or on any backhoe bucket, materials hoist, or any other similar device not specifically designed for carrying passengers.

- All drilling team members must make a conscientious effort to remain aware of their own and others' positions in regards to rotating equipment, cat heads, or u-joints. Driiling operations members must be extremely careful when 
assembling, lifting, and carrying flights or pipe to avoid pinch-point injuries and collisions.

- Tools and equipment will be kept off the ground whenever possible to avoid tripping hazards and the spread of contamination.

- Personnel not involved in operation of the drill rig or monitoring activities shall remain a safe distance from the rig as indicated by the field team leader.

- Personnel will follow all provisions of each site-specific HWOP as addressed in the HWOP, including cutting and welding, confined space entry, and excavation.

- Catalytic converters on the underside of vehicles are sufficiently hot to ignite dry prairie grass. Team members should not drive over dry grass that is higher than the ground clearance of the vehicle and should be aware of the potential fire hazard posed by catalytic converters at all times. Never allow a running or hot vehicle to sit in a stationary location over dry grass or other combustible materials.

- Personnel will follow all provisions of each site-specific RWP.

- Team members will attempt to minimize truck tire disturbance of all stabilized sites.

\subsubsection{Personal Protective Equipment}

The personal protective equipment specifications must be followed at all times, as directed by the field team leader, health physics technician, and site safety officer.

- Personal protective equipment will be selected specifically for the hazards identified in the HWOP. The site safety officer in conjunction with WHC Health Physics and Industrial Hygiene and Safety is responsible for choosing the appropriate type and level of protection required for different activities at the job site.

- Levels of protection shall be appropriate to the hazard to avoid either excessive exposure or additional hazards imposed by excessive levels of protection. The HWOP will contain provisions for adjusting the level of protection as necessary.

- Each employee must have a hard hat, safety glasses, and substantial protective footwear available to wear as specified in the HWOP or JSA. 
- The exclusion zone around drilling or other noisy operations will be posted "Hearing Protection Required" and team members will have noise control training.

- Personnel should maintain a high level of awareness of the limitations in mobility, dexterity, and visual impairment inherent in the use of level B and level $\mathbf{C}$ personal protective equipment.

- Personnel should be alert to the symptoms of fatigue, heat stress, and cold stress and their effects on the normal caution and judgment of personnel.

- Life jackets must be worn and employees shall use the buddy system for any activities over water (e.g., water column sampling of the Columbia River). Additional rescue equipment as required by Occupational Safety and Health Administration, Washington Industrial Safety and Health Act, or standards for working over water will be available and used.

\subsubsection{Personal Decontamination}

Measures for personal decontamination are provided below:

- The HWOP will describe in detail methods of personnel decontamination, including the use of contamination control corridors and step-off pads when appropriate.

- Thoroughly wash hands and face before eating or putting anything in the mouth to avoid hand-to-mouth contamination.

- At the end of each work day or each job, disposable clothing shall be removed and placed in (chemical contamination) drums, plastic-lined boxes or other containers as appropriate.

- Individuals are expected to thoroughly shower before leaving the work site or Hanford Site if directed to do so by the health physics technician, site safety officer, or field team leader.

\subsubsection{Emergency Preparation}

Emergency preparation measures are as follows.

- A multipurpose dry chemical fire extinguisher, a fire shovel, a complete field first-aid kit, and a portable pressurized spray wash unit shall be available at every site where there is potential for personnel contamination. 
- Prearranged hand signals or other means of emergency communication will be established when respiratory protection equipment is to be worn, because this equipment seriously impairs speech.

- The Hanford Fire Department shall be notified before the start of the site investigation project. This notification shall include the location and nature of the various types of field work activities as described in the work plan. A site location map shall be included in this notification.

\subsection{CONFINED SPACE/TEST PIT ENTRY PROCEDURES}

The following procedures apply to the entry of any confined space, which for the purpose of this document shall be defined as any space having limited egress (access to an exit) and the potential for the presence or accumulation of a toxic or explosive atmosphere. This includes manholes, certain trenches (particularly those through waste disposal areas), and all test pits $<4 \mathrm{ft}$ deep. If confined spaces are to be entered as part of the work operations, an HWOP (filled out for confined space entry) must be obtained from Industrial Safety and Fire Protection.

The identified RI activities on the 100-BC-2 operable unit should not require confined space entry. Nevertheless, the hazards associated with confined spaces are of such severity that all employees should be familiar with the safe work practices discussed in the following paragraphs.

No employee shall enter any test pit or trench deeper than $4 \mathrm{ft}$ unless the sides are shored or laid back to a stable slope as specified in 29 CFR 1926.652 or equivalent state occupational health and safety regulations.

When an employee is required to enter a pit or trench $4 \mathrm{ft}$ deep or more, an adequate means of access and egress, such as a slope of at least 2:1 to the bottom of the pit or a secure ladder or steps, shall be provided.

Before entering any confined space, including any test pit, the atmosphere will be tested for flammable gases, oxygen deficiency, and organic vapors. If other specific contamination, such as radioactive materials or other gases and vapors may be present, additional testing for those substances shall be conducted. Depending on the situation, the space may require ventilation and retesting before entry.

An employee entering a confined or partially confined space must be equipped with an appropriate level of respiratory protection in keeping with the monitoring procedures discussed previously and the action levels for airborne contaminants (see "Warnings and Action Levels" in HWOP).

No employee shall enter any test pit requiring the use of level B protection unless a backup person also equipped with a pressure-demand, self-contained breathing apparatus 
(SCBA) is present. No backup person shall attempt any emergency rescue unless a second backup person equipped with a SCBA is present, or the appropriate emergency response authorities have been notified and additional help is on the way.

\subsection{SITE BACKGROUND}

Specific details on the 100-BC-2 operable unit background and known and suspected contamination are described in Chapters 2 and 3 of the work plan. The 100-BC-2 operable unit is situated within the 100-B/C Area of the U.S. Department of Energy's (DOE) Hanford Site. The 100-B/C Area is located in the north-central part of the Hanford Site, approximately $45 \mathrm{~km} \mathrm{(28} \mathrm{mi)} \mathrm{northwest} \mathrm{of} \mathrm{the} \mathrm{city} \mathrm{of} \mathrm{Richland,} \mathrm{Washington} \mathrm{(see} \mathrm{Figure} \mathrm{1-1}$ in the work plan). The area is situated on an essentially flat, semiarid bench within the Pasco Basin, immediately southeast of the 100-BC-1 operable unit and the Columbia River. The land surface slopes gently to the north, ending in a steep embankment of about $9 \mathrm{~m}$ (30 ft) at the river's edge.

Between the years 1943 and 1963, nine water-cooled, graphite-moderated, plutonium production reactors were built within the 100 Areas of the Hanford Site. Operation of the reactors and associated facilities resulted in the generation and release of chemical and radioactive wastes into the soil, air, and water of the area. For cleanup purposes, the 100 Areas have been divided into operable units. The 100-BC-2 operable unit is one of two source operable units associated with the $100-\mathrm{B} / \mathrm{C}$ Area. A third operable unit (100-BC-5) includes the groundwater and surface water impacted by operation of the $100-\mathrm{B} / \mathrm{C}$ Area. The $100-\mathrm{BC}-2$ operable unit is immediately adjacent to the $100-\mathrm{BC}-1$ operable unit.

100-BC-2 operable unit contains the C Reactor, its operational support facilities, and the reactor cooling water effluent systems. The $C$ Reactor operated from 1952 to 1969 . The facilities within the boundaries of the 100-BC-2 operable unit are described in Chapter 2 of the work plan and shown in Figure 2-1. Wastes associated with the facilities are also discussed in Chapter 2, followed by an operable unit scale discussion of contaminants of concern in Chapter 3.

\subsection{SCOPE OF WORK AND POTENTIAL HAZARDS}

While the information presented in Section 3.1 of the work plan is believed to be representative of the constituents and quantities of wastes at the time of discharge, the present chemical nature, location, extent, and ultimate fate of these wastes in and around the liquid disposal facilities are largely unknown. The emphasis of the RI in the 100-BC-2 operable unit will be to better define the nature and extent of contamination in the vadose (unsaturated subsurface soil) zone. 


\subsection{WORK TASKS}

Work tasks are described in Chapter 5 of the work plan.

\subsection{POTENTIAL HAZARDS}

Onsite tasks will involve noninvasive surface sampling procedures and invasive soil sampling either directly in or immediately adjacent to areas known or suspected to contain potentially hazardous chemical substances, toxic metals, and radioactive materials.

Surface radiological contamination and fugitive dust will be the potential hazards of primary concern during noninvasive mapping and sampling activities.

Existing data indicate that hazardous substances may be encountered during invasive sampling; these include radionuclides, heavy metals, and corrosives. In addition, volatile organics may be associated with certain facilities such as the solvent storage buildings or underground storage tanks.

Potential hazards include the following:

- external radiation (gamma, and to a lesser extent, beta) from radioactive materials in the soil

- internal radiation resulting from radionuclides present in contaminated soil entering the body by ingestion or through open cuts and scratches

- internal radiation resulting from inhalation of particulates (dust) contaminated with radioactive materials

- inhalation of toxic vapors or gases such as volatile organics or ammonia

- inhalation or ingestion of particulates (dust) contaminated with inorganic or organic chemicals, and toxic metals

- dermal exposure to soil or groundwater contaminated with radionuclides

- dermal exposure to soil or groundwater contaminated with inorganic or organic chemicals, and toxic metals

- $\quad$ physical hazards such as noise, heat stress, and cold stress

- $\quad$ slips, trips, falls, bumps, cuts, pinch points, falling objects, other overhead hazards, crushing injuries, and other hazards typical of a construction-related job site 
- unknown or unexpected underground utilities

- biological hazards; snakes, spiders, etc.

\subsection{ASSESSMENT AND MITIGATION OF POTENTIAL HAZARDS}

The likelihood of significant exposure (100 mR/h or greater) to external radiation is remote and can be readily monitored and controlled by limiting exposure time, increasing distance, and employing shielding as required.

Internal radiation by inhalation or inadvertent ingestion of contaminated dust is a realistic concern and must be continuously evaluated by the health physics technician. Appropriate respiratory protection, protective clothing, and decontamination procedures will be implemented as necessary to reduce potential inhalation, ingestion, and dermal exposure to acceptable levels.

Dermal exposure to toxic chemical substances is not expected to pose a significant problem for the identified tasks given the use of the designated protective clothing. The appropriate level of personal protective clothing and respiratory protection will vary from work site to work site.

\subsection{ENVIRONMENTAL AND PERSONAL MONITORING}

The site safety officer or authorized delegate shall be present at all times during work activities that require an HWOP, and shall be in charge of all environmental/ personal monitoring equipment. Industrial Hygiene and Safety shall review all activities involving or potentially involving radiological exposure or contamination control and shall prescribe the appropriate level of technical support/monitoring requirements. Other equipment deemed necessary by the site safety officer or Industrial Hygiene and Safety shall be obtained at their direction; work will not be initiated or continued until such equipment is in place. These instruments are to be used only by persons who are trained in their usage and who understand their limitations. No work shall be done unless instrumentation is available and in proper working order.

Air sampling may be required downwind of the referenced waste sites to monitor particulates and vapors before job startup. Siting of such sampling devices will be determined by Health Physics, the site safety officer, and HEHF, if appropriate. Any time personnel exposure monitoring, other than radiological, is required to determine exposure levels, it must be done by HEHF. Discrete sampling of ambient air within the work zone and breathing zones will be conducted using a direct-reading instrument, as specified in the site-specific safety document, and other methods as deemed appropriate (e.g., pumps with tubes, $\mathrm{O}_{2}$ meters). The following standards will be used in determining critical levels:

- $\quad$ "Radionuclide Concentrations in Air," in Chapter XI, DOE Order 5480.1B (DOE 1986) 
- $\quad$ "Air Contaminants - Permissible Exposure Limits," in 29 CFR 1910.1000

- Threshold Limit Values and Biological Exposure Indices for 1991-1992 (ACGIH 1992)

- Occupational Safety and Health Standards, 29 CFR 1910.1000

- $\quad$ Pocket Guide to Chemical Hazards (NIOSH 1991), which provides National Institute for Occupational Safety and Health-recommended exposure limits for substances that do not have either a threshold limit value or a permissible exposure limit.

- "Part H--Air Contaminants," in Occupational Health Standards, WAC 296-62-075.

An onsite health physics technician will monitor airborne radioactive contamination levels and external radiation levels. Action levels will be consistent with derived air concentrations and applicable guidelines as specified in Radiation Protection Manual (WHC 1988a).

Appropriate respiratory protection shall be required when conditions are such that the airborne contamination levels may exceed an 8-hr derived air concentration (e.g., the presence of high levels of uncontained, loose contamination on exposed surfaces or operations that may raise excessive levels of dust contaminated with airborne radioactive materials, such as excavation or drilling under extremely dry conditions).

Specific conditions requiring the use of respiratory protection because of radioactive materiais in air will be incorporated into the RWP. If, in the judgement of the health physics technician, any of these conditions arise, work shall cease until appropriate respiratory protection is provided.

\subsection{PERSONAL PROTECTIVE EQUIPMENT}

Feasible engineering/work practice controls shall be used to control employee exposure to health and safety hazards. Where such controls are not feasible, personal protective clothing and respiratory protection shall be selected to limit exposure to anticipated chemical and radiological hazards. The initial level of personal protective equipment, when required, will be specified in the site-specific safety document for each task or group of tasks. 


\subsection{SITE CONTROL}

The field team leader, site safety officer, and health physics technician are designated to coordinate access control and security on the site. Special site control measures will be necessary to restrict public access. The zones will be clearly marked with rope/appropriate signs. The size and shape of the control zone will be dictated by the types of hazards expected, the climatic conditions, and specific operations required.

Control zone boundaries may be increased or decreased based on results of field monitoring, environmental changes, or work technique changes. The site RWP and the contractor's standard operating procedures for radiation protection may also dictate the boundary size and shape. All team members must be surveyed for radioactive contamination when leaving the controlled zone if in a radiation zone.

The onsite command post and staging area will be established near the upwind side of the control zone as determined by an onsite windsock. Exact location for the command post is to be determined just before start of work. Vehicle access, availability of utilities (power and telephone), wind direction, and proximity to sample locations should be considered in establishing a command post location.

\subsection{DECONTAMINATION PROCEDURES}

The RI activities will require entry into areas of known chemical and radiological contamination. Consequently, it is possible that personnel and equipment could be contaminated with hazardous chemical and radiological substances.

During site activities, potential sources of contamination may include airborne vapors, gases, dust, mists, and aerosols; splashes and spills; walking through contaminated areas; and handling contaminated equipment. Personnel who enter the exclusion zone will be required to go through the appropriate decontamination procedures on leaving the zone.

Decontamination procedures shall be consistent with EII 5.4, "Field Decontamination of Drilling, Well Development, and Sampling Equipment", and EII 5.5, "Decontamination of Equipment for RCRA/CERCLA Sampling" (WHC 1988b), or other approved decontamination procedures. 


\subsection{CONTINGENCY AND EMERGENCY RESPONSE PLANS}

As a general rule, in the event of an unanticipated, potentially hazardous situation indicated by instrument readings, visible contamination, unusual or excessive odors, or other indications, team members shall temporarily cease operations and move upwind to a predesignated safe area as specified in the site-specific safety documentation.

\subsection{REFERENCES}

ACGIH, 1992, Threshold Limit Values and Biological Exposure Indices for 1991-1992, American Conference of Governmental Industrial Hygienists, Cincinnati, Ohio.

DOE, 1986, Environment, Safety \& Health Program for DOE Operations, DOE Order 5480.1B, U.S. Department of Energy, Washington, D.C.

DOE-RL, 1988, Industrial Hygiene Program, DOE/RL Order 5480.10A, U.S. Department of Energy, Richland Operations Office, Richland, Washington.

NIOSH, 1991, Pocket Guide to Chemical Hazards, National Institute for Occupational Safety and Health, U.S. Department of Health and Human Services, Public Health Service, Centers for Disease Control, Washington, D.C.

WHC, 1988a, Radiation Protection Manual, WHC-CM-4-10, Westinghouse Hanford Company, Richland, Washington.

WHC, 1988b, Environmental Investigations and Site Characterization Manual, WHC-CM-7-7, Westinghouse Hanford Company, Richland, Washington. 


\section{APPENDIX C \\ INFORMATION MANAGEMENT OVERVIEW}

An extensive amount of data will be generated over the next several years in connection with the activities planned for this operable unit. The quality, storage, and accessibility of these data are extremely important to the full remediation of the operable unit as agreed on by the U.S. Department of Energy, the U.S. Environmental Protection Agency, the Washington Department of Ecology, and interested parties.

The information management overview (IMO) provides an overview of the information, data, and records related activities at the operable unit level. It identifies the source, type, and quantity of data to be collected, and references the procedures that control the collection and handling of data and records. It provides guidance for the data collector, operable unit investigator, project manager, and reviewer to fulfill their respective roles. All data collected will be in accordance with the environmental investigation instructions contained in the Environmental Investigations and Site Characterization Manual (WHC 1991a). The IMO for the 100-BC-2 operable unit is the same as that for the 100-BC-1 operable unit; therefore, it will be referenced to that work plan (DOE-RL 1992). Table C-1 has information unique to $100-\mathrm{BC}-2$ regarding quantities of information generation; therefore, it is included in this work plan.

\section{REFERENCES}

DOE-RL 1992, Remedial Investigation/Feasibility Study Work Plan for the 100-BC-1 Operable Unit, Hanford Site, Richland, Washington, DOE/RL-90-07, Rev. 0, U.S. Department of Energy, Richland Operations, Richland, Washington.

WHC, 1988, Environmental Investigations and Site Characterization Manual, WHC-CM-7-7, et seq., Westinghouse Hanford Company, Richland, Washington. 
Table C-1. Estimated Operable Unit Data Quantities. (sheet 1 of 2)

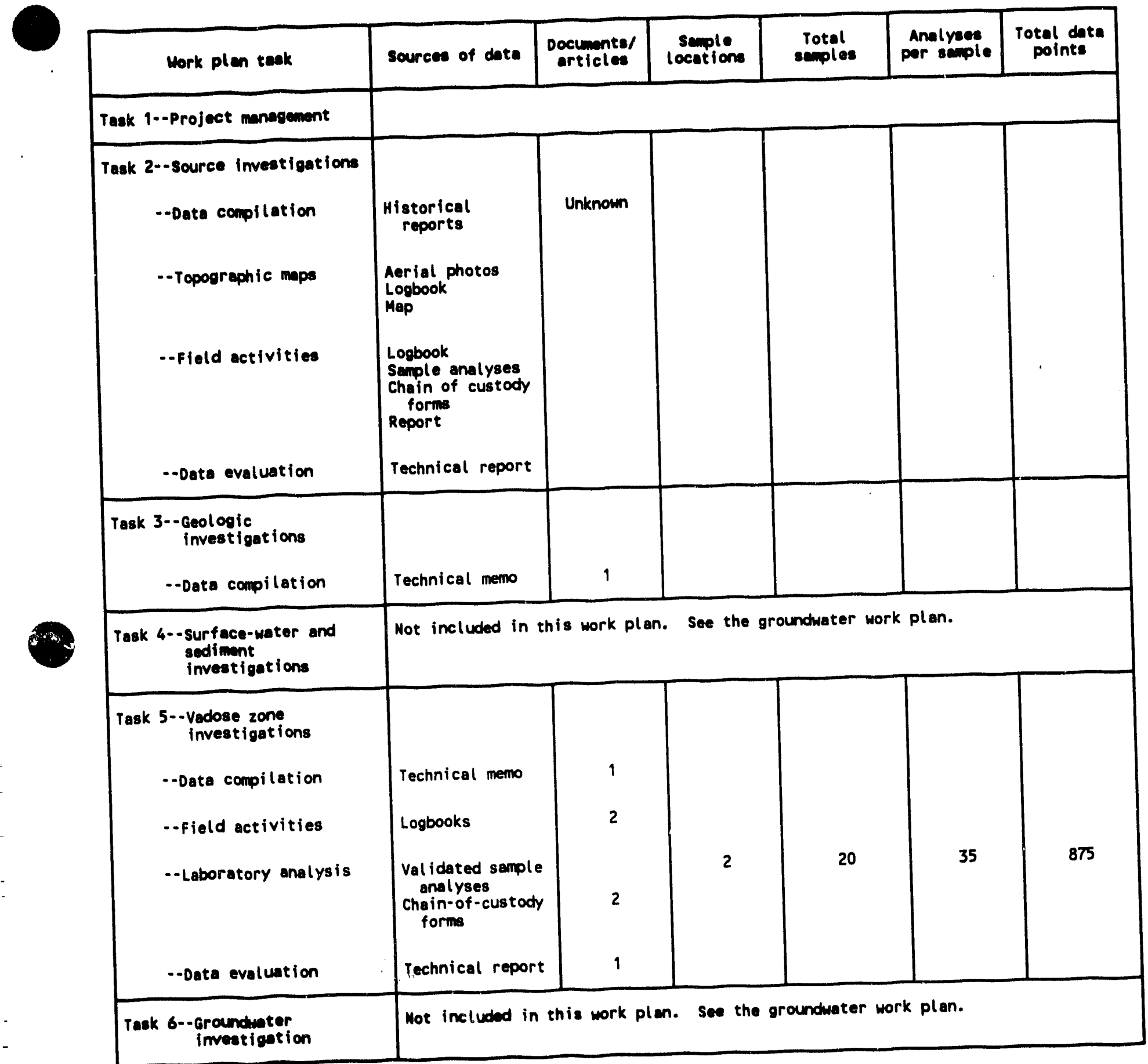


DOE/RL-91-07, Rev. 0

Table C-1. Estimated Operable Unit Data Quantities. (sheet 2 of 2)

\begin{tabular}{|c|c|c|c|c|c|c|}
\hline Hork plen task & Sources of date & $\begin{array}{l}\text { Documents/ } \\
\text { articles }\end{array}$ & $\begin{array}{l}\text { Semple } \\
\text { locations }\end{array}$ & $\begin{array}{l}\text { Total } \\
\text { samples }\end{array}$ & $\begin{array}{l}\text { Analyses } \\
\text { per sample }\end{array}$ & $\begin{array}{l}\text { Total data } \\
\text { points }\end{array}$ \\
\hline \multicolumn{7}{|l|}{ Task $7--A i r$ investigations } \\
\hline - -Data compilation & Technical memo & & & & & \\
\hline - F'eld activities & Logbook & & & & & \\
\hline -Dato analysis & $\begin{array}{l}\text { Val idated sample } \\
\text { analyses }\end{array}$ & & & & & \\
\hline --Datz evaluation & Technical report & & & & & \\
\hline $\begin{array}{r}\text { :ask 8- - Ecological } \\
\text { investigations }\end{array}$ & \multicolumn{6}{|c|}{ Hot included in this work plan. See the groundwater work plan. } \\
\hline Task 9--other investigations & Technical memo & 1 & & & & \\
\hline Task 10--Data evaluation & Technical memo & 1 & & & & \\
\hline 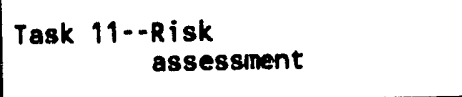 & Technical memo & 1 & & & & \\
\hline $\begin{array}{c}\text { Task } \begin{array}{c}12-- \text { Verification of } \\
\text { ARARs }\end{array} \\
\text { arion }\end{array}$ & Report & 1 & & & & \\
\hline Task 13--RI report & Report & 1 & & & & \\
\hline Note: $\begin{array}{l}\text { Initially only valida } \\
\text { categories. }\end{array}$ & d sample analysis & will be ava & ablo in HE: & See Sect $i$ & 3.0 for HEIs & data \\
\hline
\end{tabular}


DOE/RL-91-07, Rev. 0

\section{DISTRIBUTION}

Number of Copies

is

Onsite

31

U.S. Department of Energy

Richland Field Office

J. K. Erickson (30)

A5-19

Public Reading Room

A1-65

1

Pacific Northwest Laboratory

Hanford Technical Library

P8-55

48

Westinghouse Hanford Company

L. D. Arnold

B2-35

Central Files

L8-04

Correspondence Control

A3-01

EDMC (7)

H6-08

ERC (G. Fitzgibbon)

H6-07

ERE (F. Stone) (2)

ERE Project File

H6-01

H6-03

ER Program Office (2)

IRA (3)

K. O. Kytola

H6-27

H4-17

H6-02

Resource Center

N3-05

Distr-1 

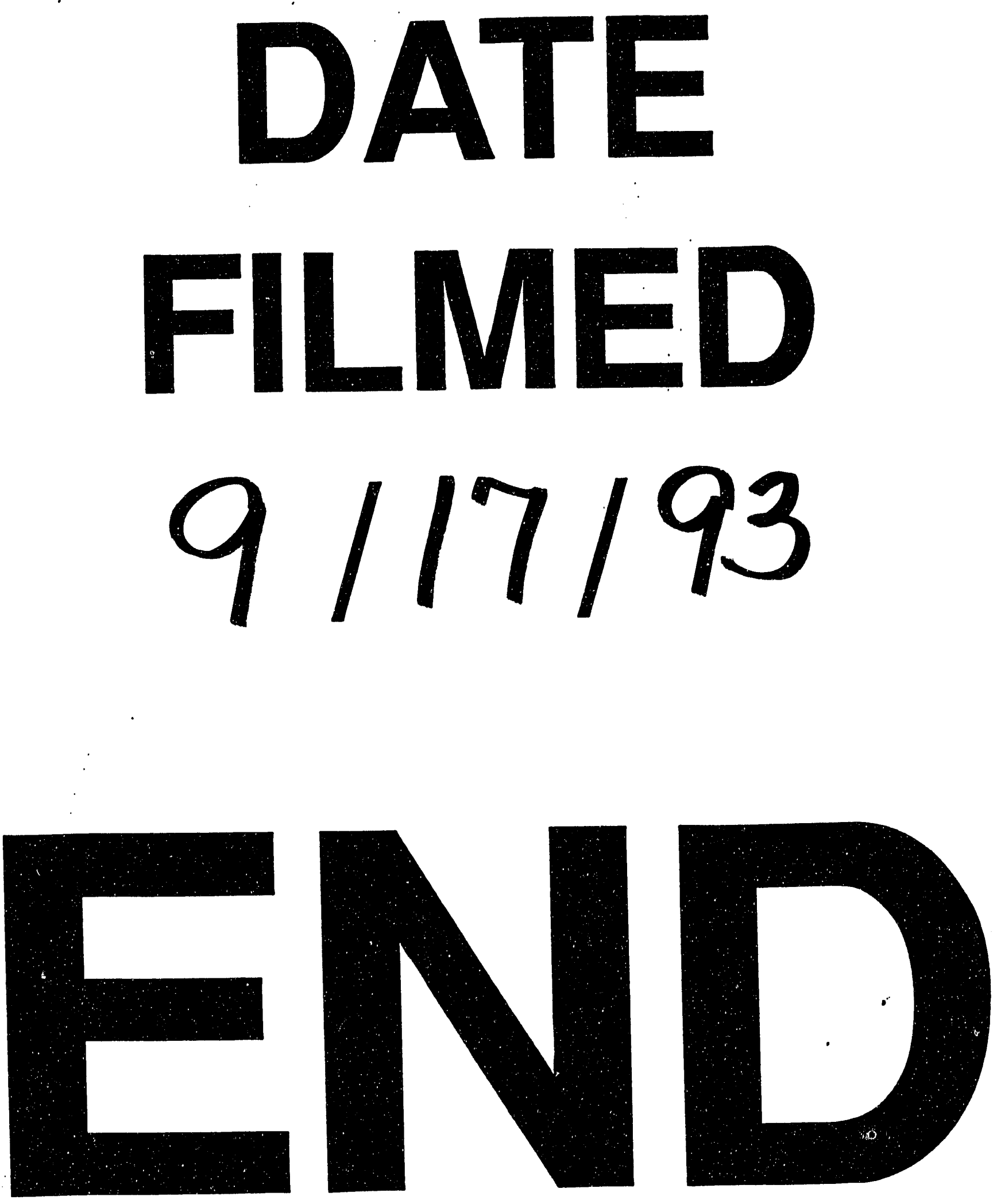


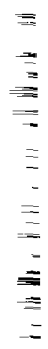

